\title{
Contigüidades culturales en las "composiciones romanas» de Bartolomé de Torres Naharro
}

\author{
Ana Cecilia Prenz \\ DIRECTOR DE LA TESIS: Dr. José Amícola \\ Universidad Nacional de La Plata \\ Facultad de Humanidades y Ciencias de la Educación
}

La Plata, marzo 2007 


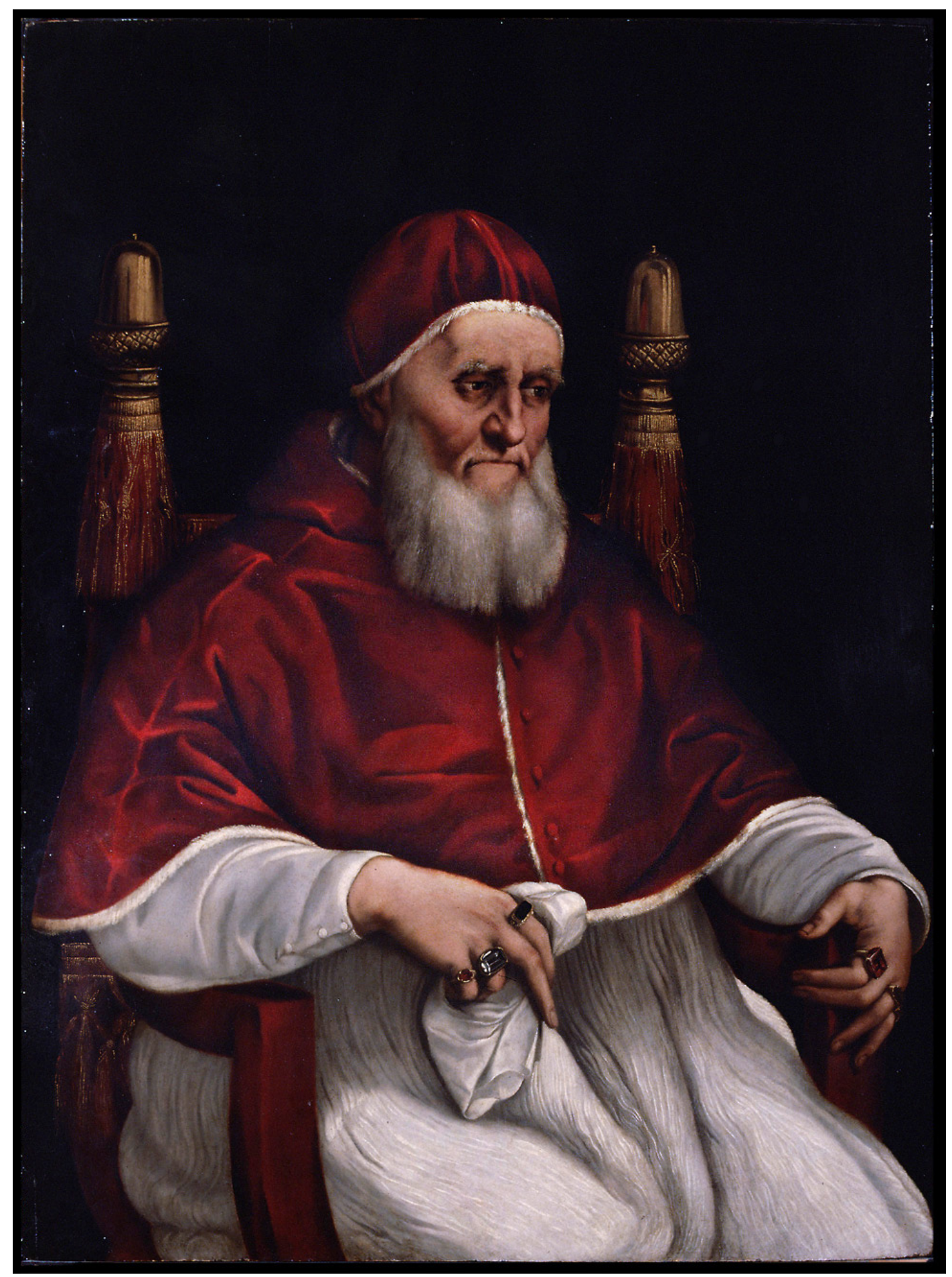

Rafael, Retrato de Papa Julio II, Florencia, Galería Palatina, 1511-1512 


\section{ÍNDICE}

\section{Introducción: problemas e hipótesis}

1. Discusión en torno al término «prelopesco»

2. El horizonte perspectivista y el concepto de lo popular

3. Lecturas de lo popular

4. Lo popular a partir de Bajtín y la significación de Torres Naharro

5. Contigüidades renacentistas

6. La mediación cultural

\section{Capítulo I}

\section{Estado de la cuestión}

1. Lo popular y la representación

2. Recepción de la obra de Torres Naharro

2.1. Inmediatamente después de la publicación de Propalladia

2.2. Siglos XVIII y XIX

2.3. Joseph Gillet

2.4. La crítica italiana

2.5. El aporte de Gilman y la fundamentación de Zimic

\section{Capítulo II}

Naharro preceptista

1. Intertexto y relaciones interculturales en Torres Naharro

2. Todo texto dialogado se llamaba «comedia»

3. El Prohemio: de la práctica a la teoría

\section{Capítulo III}

Los aportes de Bajtín en torno a lo popular como viraje hacia una nueva concepción del teatro renacentista

1. Cultura cómica popular y teatro

2. El universo bajtiniano

3. Algunos elementos que constituyen el lenguaje del realismo grotesco y que aparecen en las piezas de Torres Naharro

3.1 Elogios

3.2. Injurias y parodias 
3.3. El grito

3.4. Juramentos

4. Las imágenes del «banquete»

\section{Capítulo IV}

$\underline{\text { Naharro dramaturgo - Naharro satírico }}$

1. Una biografía controvertida

2. «Fiesta»y teatro

3. Las «composiciones romanas» de Torres Naharro

3.1. Las comedias «a noticia» Soldadesca, Tinellaria

3.1.1. La cuestión de Soldadesca

3.1.2. La cuestión de Tinellaria

3.2. La especificidad de la comedia Jacinta

3.3. Los escritos satíricos

3.3.1. La Sátira

3.3.2. El Capítulo III

3.3.3. Concilio de los Galanes y cortesanas de Roma, invocado por Cupido

4. Un excursus necesario: el Diálogo del Nacimiento

\section{Conclusiones}

\section{Bibliografía}

\section{Apéndice}

$\underline{\text { Traducción de la comedia Tinellaria al italiano }}$ 


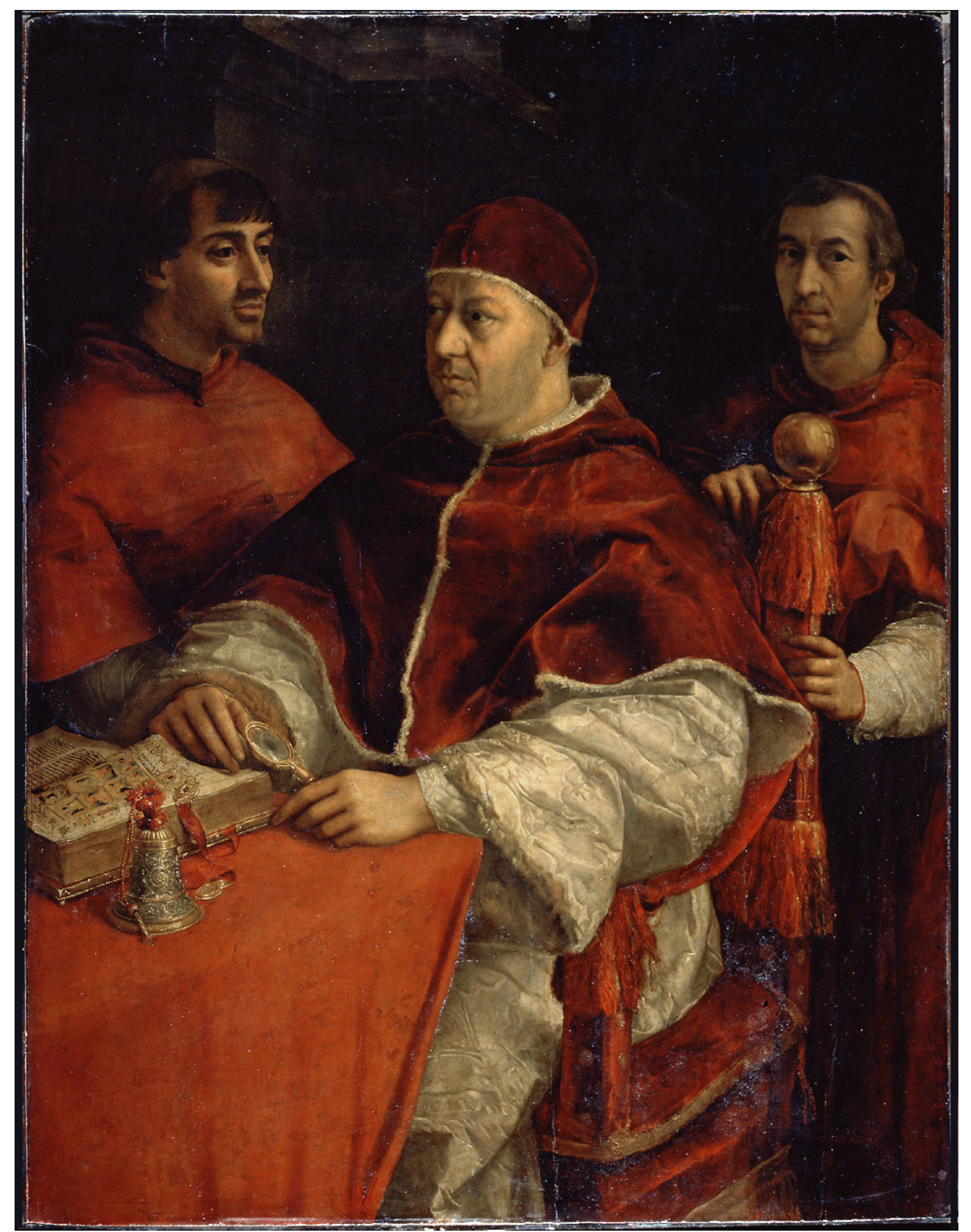

Rafael, Retrato de León X con dos cardenales, Florencia, Galería Uffizi, 1518-1519 


\section{Introducción: problemas e hipótesis}

\section{Discusión en torno al término «prelopesco»}

Los estudios críticos sobre el teatro español han tenido un referente inevitable en la obra dramática y en la reflexión teórica sobre Lope de Vega. A partir de las mismas -como un deslinde con la producción dramática anterior- se construye la historia del teatro español. Sin embargo, algunos enfoques metodológicos aplicados al análisis del problema y las resultantes conclusiones teóricas implican, a nuestro parecer, el cuestionamiento de algunos aspectos fundamentales que hacen a la dramaturgia española de comienzos del s. XVI en relación con la época posterior.

Gran parte de la crítica ha considerado y considera que el teatro español nace realmente y se desarrolla, alcanzando al mismo tiempo su máximo esplendor, con la dramaturgia de Lope. En este contexto se acuña también la expresión de teatro nacional. Por otra parte, como una periodización ya consolidada, las historias de la literatura suelen distinguir dos etapas: una primera denominada prelopesca y una segunda, nacional, que se refiere, implícitamente, al teatro a partir de Lope.

En los últimos años han comenzado a producirse estudios sobre el teatro español de los siglos XV y XVI que han revertido esta óptica. Una actitud adversa de la crítica en el pasado, había llevado a su marginación en el contexto general de los estudios literarios de los Siglos de Oro.

Frente a la imponencia y calidad estética del teatro del s. XVII, la crítica había optado por definir al teatro emergente de tradiciones medievales como una forma expresiva menor e incompleta, perteneciente a una fase de transición y formación de la literatura dramática. Con frecuencia, se encontraba la indicación de teatro prelopesco, con respecto a la producción dramática anterior a Lope, definición que marcaba con claridad el límite de un antes y un después y que llevaba implícito en sí una forma de prejuicio frente el teatro que más recientemente ha sido definido como renacentista. 
Esta visión ha sido parcialmente superada ${ }^{1}$. Con la elaboración de conceptos positivos respecto a la noción negativa de teatro prelopesco, ha sido aceptada la denominación de teatro renacentista español. Alfredo Hermenegildo en su Historia del teatro del siglo XVI (1994) indica que lo prelopesco ha estado marcado ideológicamente por el concepto centralizador de la historia política de España. Las etapas evolutivas del teatro, según el crítico, habrían sido estructuradas a posteriori como si en un primer momento se tratara de un desarrollo indefinido que habría cobrado su identidad sólo con la aparición de la comedia nueva. Los teóricos se han ocupado ya de señalar que en el estudio de la historia del teatro, no sólo de habla hispana, ha sido dominante una concepción evolutivo-determinista: «el finalismo, o bien, la tendencia teleológica a valorar los fenómenos teatrales principalmente sobre la base de aquello en que se transformaron tan sólo posteriormente, obligando así, y a menudo desnaturalizando, cada acontecimiento -por lo demás desmembrado en sus componentes- dentro de la historia evolutiva de cada uno de los 'géneros'» (De Marinis, [1988] 1997, 37). En este contexto, la obra de Torres Naharro ha sido considerada como un elemento más dentro del gran calderón de lo prelopesco.

\footnotetext{
${ }^{1}$ A partir de mediados de los años cincuenta se ha comenzado a hablar de teatro renacentista, aunque, en algunos casos, los historiadores de la literatura siguen vinculados a las interpretaciones tradicionales. Algunos ejemplos al respecto: Ruiz Ramón, en Historia del teatro ([1966], 2000) opta por hablar de «La generación de los Reyes Católicos» refiriéndose a Encina, Naharro, Vicente, los otros entran dentro de categorías como «teatro ambulante», «los trágicos» o simplemente «Juan de la Cueva y Cervantes», el capítulo dedicado al teatro del siglo XVII lleva el nombre de «El teatro nacional del Siglo de Oro», (el subrayado es nuestro). La Historia de la literatura española 3. Siglo de oro: teatro de Wilson y Moir (1974) distingue a los autores por períodos: «Desde J.del Encina hasta mediados del s. XVI» y «De Lope de Rueda a Cervantes». La Historia y Crítica de la Literatura española, Siglos de oro: Renacimiento de Rico y López Estrada (1980), mantienen la definición de «teatro prelopesco».

En Italia, Profeti, Introduzione allo studio del teatro spagnolo (1994), dedica amplio espacio a aspectos que van más allá del texto, es decir: el lugar de la representación, el espectáculo, el actor; sin embargo, el capítulo dedicado al teatro del s. XVI mantiene un sabor pespectivista y se titula «La prima metà del Cinquecento: verso il «corral».

Más recientemente, estudiosos del teatro del s.XVI, han introducido en sus historias y ediciones la indicación de teatro renacentista, distinguiéndolo claramente del teatro barroco: Pérez Priego, Teatro renacentista (1987), Estudios sobre el teatro del Renacimiento (1998); Hermenegildo Teatro Renacentista (1990). Huerta Calvo en la Historia del teatro español. De la Edad Media a los Siglos de Oro (I, 2003) hace una división por siglos (siglo XV, siglo XVI) en la que aparece, naturalmente, el término renacentista. Este último texto mencionado representa el trabajo más exhaustivo en ámbito hispánico sobre la historia del teatro español, en general, y renacentista, en particular.
} 
El teatro del s. XVI no se crea en la perspectiva de la llegada de Lope; por el contrario, tiene su propia existencia. «Lope de Vega no está en la mente de Torres Naharro. Naharro sí está en la mente de Lope de Vega» (Hermenegildo, 1994, 16). Por lo tanto, se ha tratado de dejar de lado el sintagma prelopesco y se ha comenzado a hablar de este teatro sólo en referencia a sí mismo.

Joseph Gillet, cuya obra Propalladia and other works of Bartolomé de Torres Naharro (1943-1961) representa el estudio más exhaustivo sobre el autor, cae, de alguna manera, en el mismo error cuando intenta focalizar el pensamiento de fondo y el lenguaje que rigen la obra de Naharro. Por una parte, encuentra en sus textos cierto «primitivismo»y «medievalismo»-como asimismo «renacentismo»-, que ven a un Naharro apegado a la tradición; por la otra, -supuestamente-, individualiza en el dramaturgo al fundador del drama español del s. XVI y por consiguiente del Siglo de Oro. Nos referimos al capítulo VII, «Torres Naharro and the Spanish Drama», de Propalladia and other works of Bartolomé de Torres Naharro, (1961) que, como sabemos, Gillet no alcanzó a completar y que O.H. Green finalizó siguiendo indicaciones, bocetos y comentarios del mismo Gillet. Esta doble lectura de Naharro nos plantea nuevamente la cuestión apenas mencionada, es decir, o interpretamos este teatro como arraigado en la tradición o lo concebimos en función de lo que llega posteriormente. De ninguna manera por lo que es en sí mismo.

Stanislav Zimic, -que ha dedicado interesantes páginas al erasmismo en la obra de Naharro- critica aquella «simplicity of mind» ${ }^{2}$ que Gillet encuentra en Naharro. La interpretación de Gillet ha llevado «a la comprensión errónea de Torres Naharro como pensador indefinido e indefinible: a veces reaccionario, otras veces inexplicablemente precoz, desconcertado, indeciso, chabacanamente convencional. La mente de Torres Naharro, según la explicación de Gillet, sería un receptáculo donde todo cupiera y

\footnotetext{
${ }^{2}$ «When, in this case as in others (notably in the case of Cervantes), such statements are discounted by realizing how much in them might be due to tradition (which neutralizes all it touches), to a certain simplicity of mind, to the temptation of easly achieving a comic effect, the residuum of personal indignation may be relatively small.» (cit. Gillet en Zimic, 1976, 48). Con respecto a la supuesta preocupación de Naharro de encontrar un fácil efecto cómico («easly achieving a comic effect»), Zimic escribe que Naharro emplea «lo cómico como estricta función moral, desde el punto de vista individual y social» $(1976,49)$.
} 
donde todo permaneciera inmóvil como un peso muerto: elementos primitivos, medievales, renacentistas, etc.» $(1976,48)$.

Es interesante subrayar que Gillet, no obstante los cuatro tomos dedicados al estudio de la obra de Naharro, no logra analizar su obra sino en función de la tradición, primero, y del teatro posterior, después. A pesar de esta breve consideración, -y anticipando en parte el núcleo de esta investigación, es decir el estudio de lo popular en las « piezas romanas» de Naharro- compartimos la idea de Zimic según la cual «Torres Naharro habla de su propio mundo y se dirige a su propio mundo» (1976, 50). Agregaríamos, además, que lo hace con los códigos teatrales y literarios de su época, lejanos aún de aquellos que se introducirán en el futuro próximo.

\section{El horizonte perspectivista y el concepto de lo popular}

La crítica ha individualizado en el texto dramático español algunas características como, asimismo, una autonomía literaria que la diferencian de otras dramaturgias europeas confiriéndole una identidad precisa. Sin embargo, aquellas características que permiten enmarcar el teatro español como específico, autónomo y fundamentalmente nacional y popular con respecto a la mayor proyección universal de otros teatros europeos, no necesariamente constituyen características exclusivas de Lope.

El concepto de popular, que recurre frecuentemente como un aspecto caracterizante y definitorio de la literatura dramática española, ha asumido, no obstante, contornos y componentes poco claros. Como hemos visto, el mismo se afirma y adquiere un significado amplio - no exhaustivo, seguramente- con la obra de Lope. Escribía Francisco Ruiz Ramón en 1966 respecto a Lope: «... lo radicalmente actual era el punto de vista español -y aquí español no es accidental, sino esencialdesde donde o a través del cual se interpretaba la realidad del universo. Ese punto de vista, compartido - porque convivido- por cada espectador, permite el nacimiento de 
un teatro popular, fenómeno éste que muy raras veces se da en la historia del teatro universal» ([1966], 2000, 149).

En este sentido, la producción dramática de Lope se convierte, por una parte, en un referente insoslayable para el enfoque de la temática en cuestión, pero, por otra, semejante referencia implica poner en discusión una serie de cuestiones que, inevitablemente, nos llevarán a la ruptura de esa actitud crítica que impone su figura como eje central y fundamento del discurso que nos ocupa.

Aunque en el campo teatral, el problema asume una especificidad concreta, el problema de lo popular y de lo nacional atañe también a otros géneros de la literatura española. Bastaría citar, en el campo de la épica, las discusiones en torno al Poema del Cid o los trabajos comparativos que tratan del mismo y de La Chanson de Roland. Al tratar el tema, en este caso referido a la poesía juglaresca, Menéndez Pidal tropezó con dificultades similares a la hora de establecer los marcos posibles del concepto de popular y resolvió de otro modo el problema. Sus reflexiones al respecto -en Poesía juglaresca y juglares. Orígenes de las literaturas románicas ([1942], 1991,)constituyen una referencia interesante para comprender la índole del problema. Al desarrollar la teoría de que la poesía juglaresca vive en variantes y refundiciones, recurre al procedimiento de reemplazar el concepto de poesía popular por el de poesía tradicional, poniendo en evidencia la imposibilidad de poder trazar límites rigurosos entre poesía culta y popular, transmisión oral y culta, poesía amorosa sagrada y profana, vida eclesiástica y secular, Menéndez Pidal escoge un nuevo término que, más que deslindar, intenta abarcar estos aspectos fronterizos que encuentra en el desarrollo de la juglaresca. Por otra parte, el término popular aplicado a la literatura ha sido ampliamente discutido y juzgado como insatisfactorio por Paul Zumthor (1983) que lo considera insuficientemente abarcador de todo lo que se quiere señalar con el mismo. Dado que otros aspectos fronterizos aparecen también en la producción teatral de comienzos del s. XVI, se trata de ver si -más allá de encontrar un nombre superador, lo que implicaría proyectar un objeto de estudio cuyos límites excederían de lo popular-se puede precisar el concepto de popular. 
En el desarrollo del concepto de popular en la literatura dramática española existen, pues, a nuestro juicio, imprecisiones o falencias ligadas, en modo bastante considerable, en primer lugar, a la ausencia o escasez de marcos metodológicos adecuados para estudiar el problema. Cuando se habla de lo popular tropezamos en general con una delimitación genérica, nunca específica del tema. El concepto de popular aparece, así, como una construcción hipotética débil, que no ha seguido, de un modo exhaustivo y sistemático los pasos previos de una investigación inductiva, razón por la cual semejante construcción hipotética no puede, por una parte, ser aplicada a todas las obras presuntamente populares, ni puede individualizar de un modo preciso el objeto de estudio. De este modo, el carácter de una obra aparece como popular a partir de enfoques y elementos parciales, que no pocas veces revisten un carácter tautológico: o bien porque tiene personajes populares, o porque habla de temas populares, o porque está dirigida al pueblo, o porque el pueblo se reconoce en la historia, o porque se representa en la plaza, o todos estos elementos juntos o sólo uno de ellos, sin llegar a una delimitación clara del concepto. Por otra parte, otra materia a dilucidar es cuándo y en qué términos un género -o una especie del mismo- es popular o si se trata de un género «alto» que trata temáticas populares. Delimitar estrictamente los campos, en presencia también de una contaminación constante, no sólo de los géneros, sino también de aquellos aspectos que se refieren al arte teatral, a las relaciones entre la dramaturgia y la textualidad performativa-de la cual tenemos apenas referencias generales cuando se trata de tiempos lejanos- que no pueden no repercutir en la escritura de textos dramáticos posteriores, implica necesariamente modificar las líneas metodológicas con que ha sido analizado el problema.

Por lo tanto, la hipótesis que se pretende demostrar en este trabajo es que el término popular, así como se aplica en el ámbito de la literatura dramática española del s. XVII resulta inoperante respecto al teatro de comienzos del s. XVI $-\mathrm{y}$, de manera particular, respecto a la obra de Bartolomé de Torres Naharro- por ahistórico. El presente trabajo - que de algún modo critica y propone un tratamiento diferente del problema-, se centra en las composiciones romanas de Naharro y se propone estudiar tanto las contigüidades culturales en que se producen y en las que vive el autor, 
cuanto las que el autor ha llevado a su obra y la determinan. La comedias «a noticia» de Torres Naharro serán estudiadas en el ámbito específico de las manifestaciones teatrales del la época de Julio II y León X, tratando de reubicar al autor, de un modo autónomo y con destellos propios, en la producción dramática del Renacimiento.

\section{Lecturas de lo popular}

Para encarar el estudio del significado que adquiere el concepto de popular en las «piezas romanas» de Torres Naharro no podemos prescindir del trabajo llevado a cabo por Mijail Bajtín sobre la cultura cómica popular en la Edad Media y en el Renacimiento. El crítico ruso es quien plantea las bases teóricas de la discusión en torno a lo popular a partir del estudio de la obra de Rabelais. Las problemáticas que implica el estudio de lo popular en literatura son muchas, antiguas y no siempre de fácil y posible solución. El camino indicado por Bajtín en los años 60, representa un momento crucial en el estudio de la cultura popular. Su estudio, según nuestro parecer, indica aún, y sobre todo en referencia a la época que nos ocupa, -las dos primeras décadas del s. XVI-, la vía que se debería recorrer para comprender la complejidad de fenómenos y contigüidades contextuales en las que obra Torres Naharro.

El 'descubrimiento' (teórico) del pueblo o de lo popular a cargo de los románticos, y las consiguientes reflexiones teóricas sobre el mismo, -primera y fundamental la dicotomía cultura del pueblo/cultura de los doctos ${ }^{3}-$, determinan de manera incisiva el recorrido de las interpretaciones posteriores de dicho concepto. Los textos ya clásicos - no por ello menos vigentes- de Peter Burke, Mihail Bajtín, Carlo Ginzburg han indicado las coordinadas principales del análisis de lo popular en la Edad Media y en el Renacimiento, aunque estudiosos como Gramsci, Geertz, Bollème han aclarado, también a partir de otras perspectivas, muchos aspectos inherentes al concepto. Tampoco debemos olvidar los aportes más recientes de

\footnotetext{
${ }^{3}$ Términos que, como sabemos, introdujo por primera vez Herder.
} 
Chartier, Bourdieu, De Certau, Grignon-Passeron y otros, ni los estudios sobre la cultura de masas que, -en otras disciplinas no estrictamente literarias-, han optado por introducir denominaciones como «sincretismo» (Bell, 1960; 1974), «hibridación» (García Canclini, 1990), o «contaminación cultural», términos que permiten relevar los cruces constantes y las complejas interacciones que se dan a nivel cultural, y también en lo literario. Sin embargo, como indica Oscar Blanco en la introducción al estudio de conjunto sobre la Cultura popular y cultura de masas, las discusiones y estudios en torno a la cultura popular se encuentran «en pleno proceso de revisión y, por lo tanto resulta una zona todavía en disputa» (AA.VV, 2000, 18). «El estudio del problema de la cultura popular implica, ante todo, una toma de posición» (17). Los teóricos hasta ahora han encontrado cierto acuerdo respecto a las aproximaciones fundamentales a la problemática de la cultura popular, y aquí resultan ser fundamentales los autores definidos clásicos, pero no ha ocurrido lo mismo con las «categorías teóricas fundamentales que se usaron y se usan para pensar la cultura popular» (17). Esto se debe al hecho de que las «distintas perspectivas teóricas, abrevándose en los mismos trabajos clásicos ya mencionados, han recortado distintas categorías que consideran centrales, o porque, incluso, en torno a ellas han tenido lugar y se siguen produciendo distintas interpretaciones que instalan periódicas polémicas» $(17)^{4}$. Dos son los grandes ejes en torno a los cuales se intenta definir la cultura popular, por una lado, se la interpreta «en términos de ausencia de opción, de conjunto indiferenciado de carencias, de exclusión, de síntesis, como un silencio tensionante y acusador», por el otro, diferentes perspectivas «se preguntan si la cultura popular existe, fuera del gesto que la suprime» (18). Como indica Blanco, citando a Burke, si todos los miembros de una sociedad dada tuvieran la misma cultura no sería necesario utilizar el término cultura popular (18). Resulta claro que

\footnotetext{
${ }^{4}$ «Ante tal perspectiva surgen dos alternativas posibles: se historizan dichas categorías o se toma una decisión que implica una toma de posición, es decir, se recorta, dentro del espectro existente de herramientas para el abordaje de la problemática focalizada, una serie de ellas y se sostiene que las elegidas son las categorías centrales con tal o cual significación e interpretación, lo cual trae aparejado, por consiguiente, el recorte de un objeto y el planteamiento de una serie de problemas que se consideran centrales y fundamentales de la cuestión cultura popular» (Blanco, AA.VV, 2000, 17-18)
} 
vivimos en sociedades con más de una cultura. $\mathrm{Y}$ esto se da en nuestra contemporaneidad como, asimismo, en nuestro pasado.

¿Qué entendemos cuando hablamos de lo popular en literatura? Ante todo, resulta evidente que nos estamos refiriendo a un concepto ambiguo. El adjetivo popular significa aquello que es relativo al pueblo. Julio Caro Baroja, en sus estudios sobre los pliegos de cordel, observaba que la nota caracterizante de dicha literatura es que «está elaborada por y para el pueblo». Y es, precisamente, la que nos puede dar una idea más clara de los procesos de formación de lo que es estrictamente popular, porque «popular es su público y popular el que vive en ella, que unas veces "crea" y otras es un rapsoda, en el sentido estricto de la palabra» (Baroja, 1990, 63). Sin embargo, no sólo lo que «ha nacido del pueblo o en el pueblo» es exclusivamente popular, sino también aquello que «el pueblo ha adoptado y hecho propio, independientemente de que haya brotado en su seno» (García de Enterría, 1997, 258).

En realidad, nos estamos refiriendo a un concepto amplio, diacrónico y de difícil definición en cuanto 'contaminado' o 'fronterizo' por/con otros mundos literarios y culturales. Este concepto controvertido y complejo, en literatura, adquiere frecuentemente significados variables y no siempre clarificadores. La primera dificultad que se presenta frente a la definición de este concepto es de carácter terminológico (García de Enterría, 1995, 9). El adjetivo popular frecuentemente ha sido adjuntado a términos como tradicional, pero así mismo han sido utilizados calificativos como oral, vulgar, marginal, literatura de las clases subalternas, etc.. Cada uno de éstos, en parte, ha aclarado algunos aspectos referentes al concepto pero, esencialmente, ha limitado su múltiple e inabarcable significado.

Luis Díaz en «Concepto de la literatura popular y conceptos conexos» (1995, 17-21), hace una consideración con respecto a la necesidad de revisar el concepto actualmente vigente de cultura popular en ámbito hispánico, sobre todo con relación al significado que adoptamos y le atribuimos al adjetivo popular. Lo popular, puesto 
en términos de aquella otra cultura, ha sido definido, equivocadamente, y también gracias a las ideas introducidas por los románticos, a través de dos aspectos: el inmovilismo y la homogeneidad. Aspecto que también subraya Peter Burke cuando dice que la dificultad de definir al pueblo sugiere la tesis de que su cultura no es un fenómeno monolítico y homogéneo y que, al contrario, se trata de una cultura extremadamente varia. El haber considerado lo popular como un mundo estático y «sin evolución» ha llevado a menudo a su definición «por exclusión». Es decir que éste ha sido definido «por oposición» (como indicamos anteriormente). «Esta otra cultura debería ser 'oral', 'anónima' y 'natural' o 'primitiva' frente a la 'escrita', 'de autor' y 'evolucionada'» (17) que el Occidente ha desarrollado. Significa que ha sido obviado el hecho de que lo popular ha tenido y tiene sus procesos de transformación y que como tal ha tenido y tiene su propia historia que, no necesariamente, ha coincidido/coincide con la 'oficial' o 'letrada'. Efectivamente, la cultura popular tiene «etapas de florecimiento y de decadencia que no suelen corresponderse con las de la cultura letrada» (García de Enterría, 1997, 259). Por lo tanto, lo popular «es, de hecho, más un proceso, que cualquier otra cosa» (Díaz, $1995,18)$.

Enterría nos habla, refiriéndose a la literatura popular, de «auténtico juego intertextual» en cuanto en ella «las interacciones se dan continuamente entre lo oral y lo escrito, entre lo letrado y lo iletrado, entre lo visual y lo auditivo», y, nos habla, al fin, de «un juego intercultural que se hace más visible que en cualquier otra parcela de lo literario» (García de Enterría, 1995, 10). Es evidente que resulta difícil alcanzar una clarificación del concepto popular, en sentido estricto y, en nuestro caso, de popular con referencia a lo dramático, en sentido amplio, que sea general y definitorio.

En este trabajo, no obstante los evidentes cruces culturales e intertextos que caracterizan la obra de Naharro, hemos decidido superar cierta terminología que, tomada de otras disciplinas, a menudo se aplica también en literatura. Los términos «contaminación»e «hibridación» sugieren de manera eficaz las problemáticas que atañen a la comprensión de las relaciones entre las culturas en los distintos momentos 
de la historia -aún más en la época contemporánea y referido a la cultura de masas- , aunque reducen, a nuestro parecer, los múltiples significados que las interacciones culturales implican. De alguna manera, desvirtúan la riqueza que caracteriza el encuentro entre dos o más culturas y sus refracciones, en nuestro caso, sobre el texto literario y espectacular. Peter Burke, que denomina el Renacimiento como una época de «alternativas polares», subrayando la constante circularidad que caracteriza este momento histórico, habla de «híbridos» culturales clásicos, en algunos casos y de «híbridos» culturales cristianos en otros (Burke, 1990, 28-32). Estos términos no nos permiten abarcar, armónicamente y en la misma medida, las cuestiones planteadas por la obra de Naharro. El concepto mismo de «contaminación», como asimismo el de «hibridación», conservan, en la mayoría de los casos, una connotación negativa, no obstante sus significados impliquen la idea de fusión, en el primer caso, y de cruces y mezclas, en el segundo. La negatividad que transmiten resulta inoperante si la transferimos a la literatura, en particular, y a la cultura, en general. El vocablo «sincretismo» quizás sea el más cercano a la definición de los contenidos de nuestro trabajo, por la idea misma de fusión y conciliación que implica. Sin embargo, para aclarar la especificidad de cada uno de los componentes que hacen a la obra de Naharrro y la relación entre los mismos, hemos preferido introducir la idea de contigüidad. Ella nos sugiere la sensación de proximidad, de afinidad y de contacto, de espacialidad compartida y no necesariamente conflictiva, entre los intertextos e interculturas que hacen a la obra de nuestro autor.

\section{Lo popular a partir de Bajtín y la significación de Torres Naharro}

Algunos títulos de estudios llevados a cabo en los años 90 en España sobre la literatura dramática de los Siglos de Oro indican que ciertos críticos han seguido la interpretación bajtiniana en el análisis de determinadas figuras teatrales pertenecientes al mundo de lo popular. Alfredo Hermengildo analiza a los pastores, simples, bobos y graciosos del teatro clásico español en Juegos dramáticos de la 
locura festiva siguiendo la lectura carnavalesca de la fiesta popular. Por otra parte, el mismo crítico, se detiene en el estudio específico de los pastores encinescos y naharrescos definiéndolos como «una manifestación de los caracteres que anidan en el loco, el bobo de la fiesta popular y carnavalesca» (1990, 37). También Huerta Calvo (1995) se remite al texto bajtiniano en el estudio sobre el teatro breve y la comicidad en los Siglos de Oro hablando, propiamente, de aquello que representa la premisa fundamental del estudio de Bajtín: la risa. El breve ejemplo de estos dos estudiosos, especialistas del teatro de la época renacentista -aunque no sólo- y su acercamiento a Bajtín nos estimula a emprender este camino, ciertos de que en la obra de Naharro se albergan muchos de los elementos de la cultura cómica popular. Bajtín, lo mencionamos anteriormente, es quien plantea las bases teóricas de la discusión en torno a lo popular y su teoría representa, también para nosotros, el punto de partida para comprender el lugar que ocupa el término popular y el significado que el mismo adquiere en la obra de Torres Naharro. Consideramos que los personajes que pueblan los textos del escritor extremeño son expresión, en parte, de lo que se ha dado en llamar literatura carnavalesca.

Esta investigación que se centra en el estudio de las «piezas romanas» de Torres Naharro, tratará de delucidar de qué manera, las «siete series», o temáticas centrales individualizadas por Bajtín en la obra de Rabelais, se encuentran también presentes en la obra de Naharro. Las enumeramos: 1) la serie del cuerpo humano desde el punto de vista anatómico y físiológico, 2) la serie del vestir, 3) la serie del comer, 4) la serie del beber y emborracharse, 5) las series sexuales, 6) la serie de la muerte, 7) las series escatológicas. Cabe recordar, como lo precisa el mismo Bajtín, que cada una de estas series posee una lógica específica, y que cada una de ellas tiene sus propias formas dominantes, aunque todas se cruzan entre sí. La concepción estética del realismo grotesco, por lo tanto, está presente en la obra de Naharro y el principio material y corporal con sus imágenes hiperbolizadas del comer, del beber y de las necesidades primarias de la vida aparecen con evidencia en las composiciones del autor. 
Con la denominación «composiciones romanas» entendemos aquellas comedias cuya acción se desarrolla en la ciudad de Roma como, asimismo, los textos cuya temática se refiere a acontecimientos o personajes relacionados con la ciudad papal.

Son pocas las informaciones que poseemos sobre la vida del autor. Sabemos por su Propalladia que se encuentra en Roma (en las primeras dos décadas del s. XVI) y allí desarrolla la actividad literaria en contacto directo con el mundo cortesano de esta ciudad. Según algunos críticos, en la corte de Giulio de' Medici (futuro Papa Clemente VII), primo del Papa León X, según otros, en la de Bernardino Carvajal. Propalladia, que reúne gran parte de la obra del autor escrita durante su permanencia en Roma, aparece publicado en Nápoles en 1517 e incluye un Prohemio, que resume las reflexiones del dramaturgo sobre el arte dramático, una carta de recomendación escrita por un amigo, Mesinierus I. Barberius Aurelianensis a Jodocus Badius Ascensius, famoso humanista e impresor parisiense de origen belga, el privilegio concedido por el Papa León X para la publicación de la obra, seis comedias: Seraphina, Trophea, Soldadesca, Tinellaria, Ymenea y Jacinta ${ }^{5}$ y una serie de composiciones poéticas como capítulos, epístolas, poemas sacros, romances, canciones e incluso tres sonetos en italiano; además, incluye una breve dedicatoria en verso del autor Ad lectores de Propalladia sua, el Psalmo de B. de T. N. en la gloriosa victoria que los españoles ovieron contra venecianos y el Concilio de los Galanes y cortesanas de Roma, invocado por Cupido. La obra está dirigida a don Fernando Dávalos, yerno de Fabrizio Colonna, de quien se considera criado.

Objeto de nuestro estudio serán las comedias Soldadesca y Tinellaria, con algunas referencias también a la comedia Jacinta y a los textos el Capitulo III, la Sátira y Concilio de los Galanes y cortesanas de Roma invocado por Cupido. El Capítulo III y la Sátira, como lo indica el mismo título, no revisten carácter teatral, aunque sí nos ubican dentro del contexto y de las ideas antirromanas de Naharro. Por otra parte, el Concilio, que el autor presenta con la estructura de los concilios

\footnotetext{
${ }^{5}$ Las nuevas ediciones de Propalladia incluyeron las dos comedias restantes del autor: primero sólo Calamita, inmediatamente después también Aquilana.
} 
ecuménicos de entonces, está concebido, según nuestra opinión, a partir de una concepción dramática.

La comedia Soldadesca se sitúa en la época del pontificado de Julio II y tiene como tema central la creación de un nuevo ejército mercenario de quinientos peones para el Papa. Las equivocaciones y enredos que surgen son continuas. Se despliegan escenas que podemos llamar de costumbre, prácticamente autónomas, en las que el autor narra los excesos y el clima degradado de los ejércitos mercenarios de la época. Las imágenes que ofrece Naharro son exageradas, hiperbolizadas, bajtinianamente grotescas, al fin. La comedia Tinellaria, en cambio, describe los preparativos de un banquete en la cocina de un cardenal romano. Pinta a través de lo que Bajtín llama degradación (sniženje), los vicios, -envidia, lujuria, pereza y mucha hambre- de los criados del cardenal de San Jano: un auténtico mosaico de un tinello de la época.

En las otras obras tomadas en consideración, por cierto satíricas, Bartolomé de Torres Naharro se detiene en la crítica aguda de los comportamientos licenciosos de la corte papal y en la denuncia de la corrupción de las costumbres en la ciudad de Roma. Los dos críticos ya mencionados, que se han ocupado ampliamente de Naharro, es decir, J. Gillet y S. Zimic, no coinciden en la identificación del blanco de ataques de Naharro en estos textos. Para Zimic, el personaje criticado por el autor extremeño es, casi siempre, el Papa Julio II, para Gillet en algunos casos se trata de Alejandro VI -en el Capítulo- en otros de León X -en el Concilio. Más allá de la identificación del personaje satirizado, queda claro que Naharro es profundamente partícipe de los acontecimientos históricos que caracterizan aquellos años turbulentos de transición hacia la modernidad. No olvidemos el surgir de las nuevas monarquías nacionales, el gran imperio de Carlos $\mathrm{V}$-dos años después de la publicación de Propalladia- como tampoco la reforma religiosa de Lutero que encuentra, no por casualidad, en las personalidades de Julio II y de León X, a los mayores responsables de la corrupción de la Iglesia. Por otra parte, Italia, con sus pequeños Estados (si así pueden llamarse las conformaciones políticas de aquel período) es, más de una vez, objeto de contienda para las monarquías extranjeras. El territorio de la península se 
convierte, de hecho, en un espacio conflictivo, y el estado pontificio, tan cuestionado por Naharro, su centro.

El Capitulo III es un poema satírico en el que el autor, con el mismo espíritu que anima las piezas mencionadas dirige su atención a la ciudad de Roma. Ésta representa para Naharro, así como lo era para Erasmo de Rotterdam, el centro de toda iniquidad. La Sátira, es un ejemplo más de crítica aguda al Papa, padre espiritual de la cristiandad, cuyo comportamiento en nada corresponde a lo que debería ser su función. Contrariamente a la interpretación que hace Gillet del primer verso de la Sátira, «Aquel que sus hijos está deshaciendo» identificando al personaje con la figura de Saturno-Chronos, Zimic, en su estudio, intenta demostrar la hipótesis de que el Papa discutido fuera, quizás, Julio II.

El Concilio de los Galanes y cortesanas de Roma invocado por Cupido, es también un poema satírico, en el que Naharro denuncia, una vez más, el comportamiento licencioso de los cortesanos. Se trata de mostrar el espíritu orgiástico y sensual de la corte papal. Adonde la corte va (en este caso a Boloña), lleva consigo sus males.

Stanislav Zimic dedica amplias páginas en «El pensamiento humanístico y satírico de Torres Naharro» (1976/7/8) para demostrar que la unidad de pensamiento que caracteriza la obra de Naharro se inspira en la doctrina reformista de Erasmo de Rotterdam. El crítico ve en Naharro a un intelectual del Renacimiento, activo y crítico, un hombre que se inspira fundamentalmente en Erasmo y en cuya obra «no falta ninguna de las posturas fundamentales de lo que conocemos como erasmismo». Observa en el autor la presencia de una constante sátira social en contra de la corrupción dominante en las instituciones religiosas, y no sólo, de la época. Un ejemplo son las ya mencionadas comedias Soldadesca y Tinellaria como asimismo la Sátira y el Capítulo III de Propalladia. Zimic no comparte la idea de quienes ven en Naharro a un pintor de costumbres arraigado en las fórmulas literarias del pasado. Lo cómico en Naharro tiene siempre otra función, que es la crítica de las actitudes morales de sus contemporáneos. No le interesaba en absoluto -escribe Zimicemplear determinadas escenas «por su valor de folklore o costumbre popular». Más 
bien, el autor incorpora las costumbres en sus dramas «porque ilustran tan concreta y penosamente la pedantería, la grosería y la ignorancia humanas, ostentadas con entusiasmo y una cerrada convicción de que representan la más fiel y pura devoción a Cristo» $(1976,70)$.

Citamos, con particular atención, la opinión de Zimic porque su trabajo y su propuesta de lectura de la obra de Naharro representan un referente importante en nuestra investigación.

\section{Contigüidades renacentistas}

Bartolomé de Torres Naharro es un autor de textos dramáticos y, podemos decir también, un hombre de teatro ${ }^{6}$. Junto con Juan del Encina, Lucas Fernández, Gil Vicente es considerado uno de los iniciadores del «primer teatro de los siglos dorados españoles» (Hermenegildo, 1990, 9), o, -como ha sido ya varias veces mencionado-, del teatro renacentista.

Aquí se impone una consideración de orden general: en la producción artística del Renacimiento son constantes las contigüidades -el compromiso y la conciliaciónentre los elementos clásicos y cristianos tanto que algunos estudiosos han hablado de múltiples «rinascenze» ${ }^{7}$. «El Renacimiento no fue un hecho excepcional, como lo consideraba Burckhardt, ofreciéndonos una imagen mítica y áurea del mismo, sino un mundo que busca un nuevo lenguaje en el cual son vigentes el compromiso y la conciliación entre las varias tradiciones» (Burke, 1990, 28-32). Las obras de Torres Naharro y la de sus contemporáneos no quedan al margen de esta consideración.

Estos dramaturgos, en sus obras, no responden a un modelo único de escritura dramática como tampoco a una visión única y estructurada de teatro. Si, por una

\footnotetext{
${ }^{6}$ Luisa de Aliprandini $(1985,29-31)$ lo supone metteur en escène de sus propias comedias, una de las funciones que podía llevar a cabo el cortesano literato.

${ }^{7}$ No podemos, escribe Burke, interpretar el Renacimiento como una época de ruptura improvisa con el pasado. Es más oportuno pensar en este movimiento como en un desarrollo gradual, en el que un número creciente de individuos se encuentra siempre más insatisfecho de los elementos de la tarda cultura medieval y siempre más atraído por pasado clásico (Burke, 1990, 28-32).
} 
parte, se enfrentan con la tradición de la Edad Media, -embebida de elementos populares-, con su teatro litúrgico, con la comedia escolar, con las realizaciones escénicas de la Antigüedad greco-latina, con la tradición de los momos tan relacionada con el carnaval, etc., por la otra, tampoco eluden aquellas nuevas experiencias introducidas por los humanistas. Y específicamente en lo teatral nos referimos a la recuperación y restitución de la Antigüedad vista como un ideal de vida y de cultura. Por lo tanto, no debemos olvidar que teoría y práctica, en el Renacimiento, forman parte de un mismo proceso lógico y que para los artistas de la época estos dos momentos de la creación artística resultan indivisibles. Y, en este caso, no es absolutamente casual que Naharro sienta la exigencia de formular un modelo de escritura de comedias como el que encontramos en el Prohemio a Propalladia. No debemos olvidar, tampoco, que la noción misma de teatro forma parte de un complejo de ideas y de prácticas, en el cual se entrecruzan lenguajes heterogéneos. Y más todavía: no debemos olvidar que es el momento en el que comienza a esbozarse una idea nueva de comedia, que mira hacia el futuro, pero que arrastra elementos del pasado. Más: son los años en los que se define arquitectónicamente el espacio teatral, nacen los primeros teatros, se desarrolla el concepto de escenografía, los actores se irán profesionalizando, y prospera la reflexión misma sobre el quehacer dramático. Todos estos elementos innovadores y tradicionales al mismo tiempo son los que hacen al teatro y que tan conformemente se conjugan en la obra de nuestro autor dramático. Como escribe Hermenegildo es «a partir de esa cadena intertextual -e intercultural, agregamos nosotros- que se les ofrece en toda su complejidad» $(1990,10)$ que estos autores elaboran sus propias obras.

\section{La mediación cultural}

Bajtín en su estudio plantea el tema de las distintas estéticas literarias a partir de la dicotomía cultura oficial/cultura popular. A esta oposición conceptual (cultura 
oficial/cultura popular) corresponde, como es sabido, la oposición: canon clásico, por una parte, y canon realista-grotesco, por la otra. Sin embargo, la oposición entre estas dos concepciones estéticas no deben ser absolutizadas. A nivel histórico las mezclas han sido fuertes. Y, en términos culturales, el mismo Bajtín subraya la existencia de una circulación entre ambas culturas. A través de la «apropiación» que el letrado hace de la cultura popular, ésta, -la cultura popular-, opera una captura simbólica sobre el letrado para irrumpir en la cultura oficial y, por el otro lado, las jerarquías, los ritos de la cultura oficial entran, mediante el mecanismo de la inversión y la ridiculización grotesca, en la cultura popular. Bajtín individualiza el aspecto central respecto a la intelección de la cultura popular, es decir el lugar que ocupa la figura del letrado. Alrededor de esta figura se inscribe toda la problemática del estudio de la cultura popular. La cultura popular es visible, toma cuerpo en literatura, a través de la intermediación de un letrado. Este efectúa un «pasaje», una «mediación», se convierte en «filtro», como dice Ginzburg, desde una perspectiva histórica, hace su interpretación desde un determinado punto de vista. La figura del letrado es decisiva porque es el que «restituye lo que quizás sea el problema crucial, el lugar de lucha y de intelección de todos los fenómenos de la cultura popular: la jerarquía alto/bajo y todo lo que a partir de ella entra en discusión:...» (AA.VV., 2000, 14). Carlo Ginzburg amplia aún más la idea de Bajtín. Marca un punto principal al respecto: la complementariedad o coparticipación de los elementos culturales pertenecientes, sea al ámbito de lo popular, sea al de lo oficial. Considera que existe una «Dicotomia culturale, quindi -ma anche circolarità, influsso reciproco, particolarmente intenso nella prima metà del Cinquecento, tra cultura subalterna e cultura egemonica» ([1976], 1999, xv), aunque subraya que se trata de una dicotomía aparente que remite a una cultura unitaria en la que no es posible operar cortes drásticos. Como dice Ginzburg con respecto al caso por él analizado, es decir el de Menocchio, caso límite que «ripropone con forza un problema di cui solo ora si comincia a intravedere la portata: quello delle radici popolari di gran parte dell'alta cultura europea, medievale e postmedievale. Figure come Rabelais e Bruegel non furono probabilmente splendide eccezioni. Tuttavia esse chiusero un'età caratterizzata dalla presenza di 
fecondi scambi sotterranei, in entrambe le direzioni, tra alta cultura e cultura popolare» (146).

Peter Burke identifica dos momentos distintos en la percepción de la cultura popular: un primer momento -desde 1500 hasta 1650- caracterizado por un intercambio entre cultura baja y cultura alta. Ambas culturas participan de una misma cultura. Según su opinión en ese momento la cultura alta interviene directamente en las formas populares de la cultura. Más tarde, después del 1650, los distintos acontecimientos sociales e históricos, de modo particular la Reforma y la Contrarreforma con sus obstinadas actitudes hacia la autoafirmación, determinan una clara separación entre ambas culturas causando la «muerte» de la cultura popular. Con respecto a esta participación de las clases superiores en la cultura popular, Burke escribe que fue verdaderamente considerable el cambio de las actitudes en los hombres de cultura: en el s. XVI, efectivamente, ellos despreciaban a la gente del pueblo pero compartían su cultura, en el s. XVIII, en cambio, sus descendientes habían dejado de participar espontáneamente en la cultura popular, pero llegaban al punto de descubrirla nuevamente como algo exótico y, por lo tanto, interesante. Es más, ellos comenzaban a admirar a aquel mismo «pueblo», del cual esta cultura profundamente distinta tomaba origen ${ }^{8}$.

A partir de la dicotomía cultura dominante/cultura cómica popular los críticos han destacado, por sobre todas las cosas, un único aspecto del carnaval, es decir, su fuerza de oposición a la cultura oficial. Sin embargo, este hecho, debería hacernos reflexionar sobre una cuestión clave en el planteo de Bajtín, es decir, que «il tempo e il divenire sono al centro di tutta la visione del mondo carnavalesca e del suo sistema di immagini» (Ferroni, 1971, 181) y que, por lo tanto, tal oposición tiene que ser leída en términos dialécticos (Jachia, 1992, 88). El carnaval, según Bajtín, no absolutiza nada, al contrario proclama la relatividad del hombre porque no conoce la

\footnotetext{
${ }^{8}$ «E tuttavia, se riandiamo con lo sguardo ai tre secoli di cui s'è parlato in questo libro, troviamo che il mutamento degli atteggiamenti presso gli uomini di cultura fu veramente considerevole: se nel 1500, infatti, essi disprezzavano la gente del popolo ma ne condividevano la cultura, nel 1800, invece, i loro discendenti avevano smesso di partecipare spontaneamente alla cultura popolare, ma erano al punto di riscoprirla come alcunché di esotico e, perciò, di interessante. Essi cominciavano, anzi, ad ammirare quello stesso "popolo", dal quale questa cultura profondamente diversa traeva origine» $(1980,277)$
} 
absoluta negación, como tampoco conoce la absoluta afirmación (1968, 163). El carnaval es, en realidad, la fiesta del tiempo que todo destruye y al mismo tiempo renueva, es la fiesta de la muerte que da vida y viceversa. La conciencia de esta relatividad se encuentra en todos los símbolos carnavalescos. Ellos afirman y niegan al mismo tiempo una misma realidad. Una de las categorías fundamentales, según Bajtín, para el análisis correcto del fenómeno del carnaval y de la literatura carnavalesca es reconocer que esta fiesta acerca, une, relaciona, combina sacro y profano, sublime e ínfimo, grande y mezquino, sabio y estulto, etc. $(1968,161)$. El Carnaval no permite absolutizar ninguno de los dos polos del devenir, al contrario, éstos existen en una «circularidad dialéctica».

A modo de resumen de las ideas antes expuestas, es importante repetir que en el presente trabajo de investigación se sostendrá lo siguiente:

Torres Naharro es un escritor de piezas teatrales y Torres Naharro es un hombre de teatro. No se trata aquí de una redundancia, pues: «Si el teatro es teatro, lo es solamente cuando se realiza como ceremonia en el momento de la representación. Los textos que conservamos no son más que literatura dramática que guarda en su interior una virtualidad de representación, una posibilidad de llegar a ser teatro». (Hermenegildo, 1990, 10). Sin embargo, si no conocemos, o intentamos suponer, aquello que puede haber sido la representación, difícilmente lograremos abarcar el significado profundo que estos textos implícitamente arrastran consigo. Optamos, por lo tanto, por el término contigüidades y éstas en Naharro son muchas: lo culto y lo popular comparten espacios contiguos, la representación misma se realiza en una contigüidad espacial, la intertextualidad medieval y renacentista contiguamente se expresan en la escritura dramática.

El teatro es un ejemplo perfecto de unión entre distintas formas de producción cultural ya que utiliza conjuntamente varias formas de comunicación. Como tal se convierte en un objeto de estudio privilegiado del hecho dramatúrgico a comienzos del s. XVI. 


\section{Capítulo I}




\section{Estado de la cuestión}

\section{Lo popular y la representación}

Nos detenemos en dos cuestiones para establecer el marco dentro del que se circunscriben los estudios tomados en consideración y el enfoque con el que se examinarán los mismos. Ante todo: ¿cómo se ha colocado la crítica frente al concepto de lo popular en la obra de Bartolomé de Torres Naharro? De inmediato, podemos decir, y resulta casi una consecuencia lógica de las cuestiones planteadas en la introducción -el perspectivismo que caracteriza los estudios críticos sobre el teatro del s. XVI y la centralidad de Lope de Vega- que son muy pocos los críticos que se han ocupado del estudio de lo popular, específicamente, en la dramática del autor extremeño. Si lo han hecho, esto ha sido de manera circunscripta y tomando en consideración sólo situaciones o personajes específicos de las comedias. Un ejemplo podría ser el estudio sobre la figura del rústico en los introitos del autor; otro, a partir de sus comedias, la interpretación del soldado español en Italia, etc. En este sentido, recordamos el análisis llevado a cabo por María Rosa Lida (1958) y, en tiempos más recientes, los trabajos de A. Hermenegildo sobre el rústico en el introito de la comedia Soldadesca y el estudio sobre los Juegos Dramáticos de la Locura Festiva que, en muchos aspectos, puntualiza las coordinadas para tratar el tema en términos bajtinianos (1990, 153-166). Asimismo resultan interesantes aquellos estudios de conjunto sobre el teatro del s. XVI ${ }^{9}$, que incluyen también a T. Naharro, y que colocan el análisis, entre otros, dentro del lenguaje del realismo grotesco. Igualmente

\footnotetext{
${ }^{9}$ Díez Borque (1984, 1987, 1996); Hermenegildo (1975, 1990, 1994, 1995, 1998); Huerta Calvo (1984, 1995, 2003); Salomon (1985); Pérez Priego (1987, 1998, 1993); AA.VV, Oleza Simó (dir.), (1984, 1986); Diago, Ferrer (eds.), (1991).
} 
atractiva es la idea que desarrolla Gillet (1961) sobre lo primitivo en Naharro y a la misma le dedicamos un apartado en las páginas siguientes.

La segunda cuestión tiene que ver con el texto dramático en cuanto representación. Sólo en la segunda mitad del s. XX, puede parecer una observación obvia, los estudiosos empiezan a tomar en consideración el aspecto espectacular de la obra de Naharro. Es decir, el texto no se convierte en la única fuente de investigación sino que también otros aspectos inherentes al arte del teatro entran en juego y, en este sentido, fundamental importancia adquieren las contribuciones de estudiosos ya citados como Hermenegildo, pero también toda una corriente de teóricos que invierten el curso de la crítica respecto al teatro del s. XVI: José María Díez Borque, Joan Oleza Simó, Miguel Ángel Pérez Priego, Teresa Ferrer Valls, José Luis Canet Vallés, Huerta Calvo ${ }^{10}$, etc. Ellos, excepto en algunos $\operatorname{casos}^{11}$, no se detienen en el análisis único de Naharro; al contrario, lo incluyen en trabajos de más amplio aliento. En particular, sobre el carácter espectacular de la obra de Naharro, cabe recordar -en Italia- el estudio de Luisa de Aliprandini sobre la comedia Tinellaria que se detiene en la figura de Torres Naharro como director de escena y actor como asimismo en reflexiones sobre el espectáculo en la Roma de los primeros años del s. XVI. La representación resulta importante porque bien sabemos cuán relacionados -hablamos de espacios contiguos- se encuentran la fiesta, como lugar de expresión del lenguaje popular, como asimismo, la fiesta como concepto eje en torno al cual se construye la teatralidad del primer Renacimiento.

Destacaremos, por lo tanto, cómo ha tratado la crítica lo popular también en relación al aspecto espectacular y al estrecho vínculo que los une.

\footnotetext{
${ }^{10}$ Consultar nota precedente.

${ }^{11}$ Hermenegildo (1990; 153-166); Oleza Simó (2004; 233-248); Pérez Priego (1994).
} 


\section{Recepción de la obra de Torres Naharro}

La atención que se le ha brindado a la obra de Torres Naharro a través de los siglos ha sido cambiante. Los factores son múltiples: por una parte, la fuerza estética con la que se impone la producción dramática del siglo XVII condiciona la actitud crítica respecto a las expresiones teatrales anteriores que, como ya hemos mencionado, recientemente la crítica ha optado por definir renacentistas. De alguna manera, se impone un silencio, tardíamente superado, sobre el texto teatral del siglo XVI que, a su vez, atañe a la obra de Naharro. Por la otra, las contingencias históricas que marcan la cultura literaria del s. XVI influyen sobre la difusión, lectura y representación de sus textos.

Debemos notar que, apenas en el s. XX, comienzan a desarrollarse estudios críticos representativos del autor. Las monografías son pocas -si exceptuamos el amplio estudio de Gillet J.E. (1961) y más recientemente el de Zimic S. (1978)-. En línea general, los estudiosos han preferido detenerse en el examen de aspectos parciales de sus textos. Así es que algunos analizan específicamente una comedia determinada o aquellas «a noticia» o «a fantasía» en su conjunto; otros focalizan su atención sobre las varias fuentes literarias que pueden haber inspirado a Naharro: la tradición peninsular, el contexto cultural italiano, el mundo clásico y medieval etc.; o más aún, en aspectos específicos de la lengua/lenguas y lenguajes, la actitud conversa del autor, el elemento cómico del pastor rústico, etc.

La crítica, en varias oportunidades, ha señalado la importancia que asume Naharro en el panorama teatral de comienzos del s. XVI, aunque han faltado estudios que lo contextualizaran en el amplio espectro de lo que constituye el arte teatral. Se han indicado como significativos: el haber introducido la figura del 'gracioso' (con el nombre de bobo) como antihéroe, cobarde, egoísta e interesado que "anticiparía" de alguna manera a Lope; el tratamiento del tema del honor en la comedia Himenea, para algunos la primera comedia de honor en la literatura dramática española; asimismo, se ha señalado la importancia del breve texto teórico -el Prohemio- que introduce Propalladia, el primer tentativo en lengua castellana de formular una 
preceptiva dramática. Gillet mismo ve en Naharro al fundador del drama español del s. XVI y por consiguiente el del Siglo de Oro (1961, IV, cap. VII) ${ }^{12}$. Como vemos, todo ello a partir de una actitud perspectivista del teatro, en función de los siglos posteriores y delimitando el análisis a aspectos parciales de su obra.

\subsection{Inmediatamente después de la publicación de Propalladia.}

En la primera mitad del siglo XVI las comedias de Naharro circulan ampliamente. Lo confirma el gran número de reimpresiones ${ }^{13}$ de Propalladia después de la primera edición napolitana de 1517, como asimismo la circulación de ediciones sueltas de sus comedias ${ }^{14}$. Menciones y comentarios sobre sus textos se encuentran ya en los contemporáneos. Francisco Delicado ${ }^{15}$, que comparte los ambientes cortesanos de nuestro autor en Roma, le dedica una nota en La lozana andaluza (1988, 213). Asimismo Juan de Valdés $(1985,161-162)$ y Cristóbal de Villalón $(1898,178)^{16}$ testimonian con sus citas el interés que despierta la obra del autor, también para los intelectuales. Sin embargo, después de los conflictos religiosos de la primera mitad del s. XVI, la obra de Naharro entra a formar parte del índice inquisitorial de 1559. Se crea un silencio de imprenta hasta 1573 año en el que aparece, en Madrid, una última edición expurgada. No poseemos noticias acerca de representaciones de las

12 Torres Naharro and the Spanish Drama, completado por O. H. Green.

${ }^{13}$ Reimpresiones de la obra de Naharro después del 1517: Sevilla 1520, 1526,1534 y 1545; Nápoles 1524; Toledo 1535; Amberes 1548; Madrid 1573.

${ }^{14}$ Gillet (1943, I, 85-86).

${ }^{15}$ F. Delicado en la La lozana andaluza en su referencia a la Tinellaria nos deja intuir cuánto las comedias de Naharro eran apreciadas y leídas en los ambientes romanos: «Mi señor, no sea mañana ni el sábado, que terné priessa, pero sea el domingo a çena y todo el lunes, porque quiero que me leáis, vos que tenéis graçia, las coplas de Fajardo y la comedia Tinelaria y a Çelestina, que huelgo de oír leer estas cosas muncho».

${ }^{16}$ Valdés en el Diálogo de la lengua elogia a Naharro y hace algunas observaciones con respecto a algunas comedias: «El estilo que tiene Torres Naharro en su Propaladia, aunque peca algo en las comedias, no guardando bien el decoro de las personas, me satisfaze mucho, porque es muy llano y sin afectación ninguna, mayormente en las comedias Calamita y Aquilana, porque en las otras tiene de todo, y aun en estas ay algunas cosas que se podrían dezir mejor, más casta, más clara y más llanamente». En la boca de Pacheco agrega «Mejor dixiera assí [Torres Naharro]. Pero no se lo neguemos, que mucho ha ilustrado la lengua castellana». Villalón en su Ingeniosa comparación entre lo antiguo y lo presente escribe: «Nunca alguno mostró en verso tanta agudeza como en las que Torres Naharro trovó: y no ovo en la antigüedad quien con tanta facilidad metrificase» (1898). 
comedias de Torres Naharro en España, pero sí testimonios seguros de las representaciones en Italia.

Cabe recordar también que en aquellos años mencionan a T. Naharro, Diego Ramírez Pagán en su Lamentación $^{17}$ y Juan de Timoneda ${ }^{18}$ que, poco después de la publicación de la edición expurgada en la Comedia de los engaños, lo elogia. Esta y otras menciones de los contemporáneos de Torres Naharro han sido estudiadas por Menéndez Pelayo primero y luego ampliamente desmenuzadas por Gillet J.E. en sus trabajos «Torres Naharro and the Spanish drama of the Sixteenth Century» (1930; 1937) como igualmente en Propalladia (1961). También las menciona Humberto López Morales (1986) en su estudio preliminar a la edición de las comedias Soldadesca, Ymenea, Aquilana.

Nos detenemos, brevemente, en la cita de Valdés, que destaca el buen uso de la lengua en Naharro, aunque subraya críticamente aquello que, a nuestro parecer, representa el carácter innovador de la programática teatral del autor. Escribe Juan de Valdés sobre su estilo: «peca en las comedias, no guardando bien el decoro de las personas, $[\ldots]$ porque en las otras tiene de todo, y aun en estas ay algunas cosas que se podrían dezir mejor, más casta, más clara y más llanamente». Toca dos puntos centrales, importantes también para Naharro, y que el mismo dramaturgo plantea en el Prohemio de Propalladia: su posición frente a los preceptos clásicos -«todo lo cual me parece más largo de contar que necesario de oír»- alejándose así de ellos, y el papel del decoro en la composición de las comedias. «El decoro en las comedias es como el gobernalle en la nao, el cual el buen cómico siempre debe traer ante los ojos...». Según Gillet decoro significa: dar a cada cosa lo que es suyo, y en esta afirmación hay una conexión cultural con el mundo clásico donde vale el principio de la medida en todos los ámbitos de la vida. Sin embargo, el decoro implica,

17 Menéndez Pelayo (1941, 318-320) incluye las veinte estrofas de esta Lamentación fúnebre, publicada en Floresta de poesía varia, Valencia 1562. Se trata de una protesta en contra de las medidas inquisitoriales.

${ }^{18}$ Los versos de Joan Timoneda que aparecen al frente de la Comedia de los engaños dicen: "Guiando cada cual su veloz rueda / a todos los hispanos dieron lumbre / con luz tan penetrante deste carro: / El uno en metro fue Torres Naharro, / el otro en prosa, puesta ya en la cumbre, / gracioso artificial, Lope de Rueda». 
fundamentalmente, realismo, la búsqueda teatral de la verosimilitud; justamente lo que, a partir de un juicio sobre la lengua -lengua en busca de realidad-, Valdés le crítica. Y en esto se ve el carácter renovador de Naharro en el lenguaje teatral: la importancia que cubre, en su breve texto de preceptiva dramática, el teatro en cuanto objeto de comunicación, en cuanto representación. Si sus personajes no se expresaran de la manera puntual en que lo hacen -por ejemplo, los criados del tinello del cardenal o los bisoños de los ejércitos mercenarios- poco efecto habrían tenido sobre el oyente, las argumentaciones que, a través de estos personajes, se intentaban comunicar.

\subsection{Siglos XVIII y XIX}

Menéndez Pelayo en Bartolomé de Torres Naharro y su Propalladia, ([1900], 1941) recuerda un acontecimiento significativo: una disputa, a finales del s. XVIII, que ve involucrados al crítico italiano Signorelli P. N. autor de la Storia critica dei Teatri Antichi e Moderni $(1777)^{19}$ y al abate Lampillas F. X. que escribe el Saggio storico apologetico della letteratura spagnola contro le pregiudicate opinioni di alcuni moderni scrittori italiani (1778-1781) ${ }^{20}$. Quizás la disputa en sí no revele

\footnotetext{
${ }^{19}$ Se trata de una obra muy extensa: consta, en el año 1777 , de un único volumen, en la versión definitiva del 1813 consta de once tomos. «Si tratta del primo intento orientato a tracciare una storia del genere drammatico nella vastità di ciò che nel XVII secolo si intendeva per letteratura. Gli ampi capitoli dedicati al teatro spagnolo rappresentano uno tra i primi tentativi di vedere, sotto una prospettiva globale, tutta la produzione drammatica di quel paese conosciuta fino ad allora. Quest'opera, anche se oggi poco conosciuta e poco valorizzata, fu recepita con unanime entusiasmo dai contemporanei, tra cui quello dell'intimo amico Nicolás Moratín, il quale, prima della sua imprevista scomparsa nel 1780, ebbe occasione di leggere ed apprezzare la prima edizione. Allo stesso modo il figlio Leandro, esaltò l'opera dell'autore italiano, enfatizzando l'erudizione e l'imparzialità dei giudizi, sottolineando che fino ad allora nessun altro critico straniero aveva parlato con maggiore successo di Napoli Signorelli circa il merito dei drammaturghi spagnoli», Federica Cerasa, Un drammaturgo spagnolo nell'Italia di fine Settecento: uno scambio interculturale, Università degli studi della Tuscia Viterbo, Dottorato di ricerca in Storia e cultura del viaggio, Prof. Tutor Nadia Boccara.

${ }^{20}$ A raíz del comentario de Blas Nasarre (1749), en el prólogo a las comedias de Cervantes, sobre la representación de las comedias de Naharro en Roma y Nápoles y los grandes aplausos que habrían suscitado nace una disputa en torno a la obra del extremeño. Naserre afirma que Naharro enseña a escribir comedias a los italianos pero que ellos no supieron aprovechar de su enseñanza. A continuación se desarrolla un intercambio de opiniones al respecto entre el crítico italiano Signorelli P.
} 
demasiado sobre el texto dramático renacentista como tampoco sobre Naharro; sí, en cambio, sobre el entorno literario en el que se genera, particularmente atento al teatro del s. $\mathrm{XVI}^{21}$. Las discusiones sobre dramaturgia y teatro en los salones madrileños y las páginas dedicadas al teatro español por Signorelli impulsan, seguramente, la escritura de Orígenes del teatro español ([1838],1944) de Leandro Fernández de Moratín. Este estudio, que está planteado a partir de una concepción estética teatral neoclásica, es el primer tentativo de sistematizar un vasto material, hasta entonces disperso, sobre el teatro anterior a Lope de Vega. En este contexto encontramos información amplia, aunque no exhaustiva, sobre la obra de Naharro. Moratín trabaja con la edición de Propalladia de Sevilla, posterior a la de Nápoles de 1517, que incluye a las comedias Aquilana y Calamita ${ }^{22}$. Trabaja, como él mismo lo indica en el Prólogo, con las fechas conocidas de las primeras ediciones de las obras (148); con las épocas en que pudieron ser escritas o representadas, según lo que resulta de la vida de sus autores; finalmente deduce algunos datos de la lectura misma de las piezas (149). Con respecto a Naharro escribe que «manifestó mucho conocimiento de su lengua, facilidad en la versificación y talento dramático» y que «Dio a sus comedias mayor interés y extensión». Según Moratín, Naharro pintó en los personajes «caracteres y afectos convenientes a la fábula, adelantó el artificio de la composición, y sujetó algunas de sus piezas a las unidades de acción, lugar y

N y el abate Lampillas F. X.. Signorelli niega esta enseñanza y en su Storia critica dei Teatri Antichi e Moderni (1777), presenta una imagen limitada del teatro español renacentista. Por otra parte, considera las comedias de Naharro bajas, frías pueriles «senza moto teatrale, senz'arte nell'intreccio, senza verisimiglianza nella favola e senza decenza ne' costumi» (254-257). El abate Lampillas responde con el Saggio storico apologetico della letteratura spagnola contro le pregiudicate opinioni di alcuni moderni scrittori italiani (1778-1781), en defensa del teatro español. A las impugnaciones de Lampillas, Signorelli contesta dicendo que si los escritores nacionales se hubiesen anticipado a él tejiendo una historia del teatro español, menos afán le hubiera costado coordinar sus noticias, y se habría aprovechado de semejante obra con mayor satisfacción.

${ }_{21}$ Son intensas las relaciones culturales y literarias que mantienen España e Italia en los últimos decenios del siglo. Significativa, para el teatro español, es la presencia del dramaturgo, crítico e histórico del teatro Pietro Napoli Signorelli en Madrid como asimismo la intensa relación que éste establece con Moratín padre, primero, y con Moratín hijo, después.

${ }^{22}$ Orden de presentación en el Catálogo: Serafina, Trofea, Soldadesca, Tinelaria, Himenea, Jacinta, Aquilana, llevan la fecha del 1517, Calamita y Diálogo del Nacimiento 1520. Moratín (1944) habla de las varias ediciones posteriores a la napolitana y cita lo que dice la edición expurgada del 1573 «La Propaladia de Torres Naharro, obra singular y estremada en el donaire y gracia de la lengua, aunque estaba prohibida en estos reinos años había, se leía é imprimía de ordinario en los estranjeros», p. 188. 
tiempo». En otro pasaje Moratín dice que: «Representadas e impresas en Italia pasaron a España, donde sucesivamente impresas y prohibidas, y vueltas a imprimir (según el influjo de las circunstancias), sirvieron de estudio a los que entonces se aplicaron a cultivar la poesía cómica» (158).

En el s. XIX, la obra de T. Naharro aparece mencionada también en estudios de conjunto dedicados al teatro del s. XVI: Martínez de la Rosa (1827-30), Böhl de Faber (1832), E. De Tapia (1844) F. Gonzalo Morón; sin embargo, quienes se ocuparon de documentar en sus Catálogos la existencia de piezas dramáticas del s. XVI con la debida atención fueron: Bartolomé José Gallardo ${ }^{23}$, Manuel Cañete y E. Cotarelo Mori. Todos tomaron apuntes de los Catálogos de Fernando Colón, fundador, a comienzos del s. XVI de la Biblioteca que aún lleva su nombre y que hizo el famoso Catálogo o Regestrum. En el apéndice IV de su Poética, Martínez de la Rosa se centra en la actividad teórica de Torres Naharro. Analiza los núcleos de acción de las comedias aunque sus juicios están condicionados por la preocupación de las unidades.

M. Cañete y M. Pelayo inauguran los estudios críticos sobre Naharro en el s. XX. M. Cañete comienza en el 1880 una edición comentada sobre el autor que finalizará Menéndez Pelayo en 1900. A él se debe el más completo perfil biográfico de Naharro conocido hasta entonces. El estudio de M. Pelayo marca los estudios críticos posteriores hasta la llegada del trabajo de J. Gillet Propalladia and other works of Bartolomé de Torres Naharro (1961).

\subsection{Joseph Gillet}

El trabajo de Gillet -el más amplio estudio sobre la vida y obra del autor, pleno de informaciones sugestivas aunque con interpretaciones a veces colmas de

\footnotetext{
${ }^{23}$ Istoria Crítica del Injenio Español en el que habría ocupado un lugar importante la Historia del teatro, y una Desiderata, 1823 : los datos sobre este supuesto trabajo se encuentran en RodriguezMoñino, A., Historia de una infamia bibliográfica, la de San Antonio de 1823. Realidad y leyenda de lo sucedido con los libros y papeles de Don Bartolomé José Gallardo, Madrid, Catalia, 1965.
} 
entusiasmo erudito que no siempre compartimos- ofrece una nueva interpretación. En cuatro tomos -el último póstumo y completado por O.H. Green- Gillet realiza una edición minuciosamente comentada de las obras de Naharro. El trabajo significó largos años de investigación para el autor (1943-1961), aunque sus rastreos en torno a la obra de Naharro habían comenzado ya anteriormente como lo demuestran las reflexiones que le dedica al dramaturgo extremeño en análisis anteriores. En estos estudios Gillet $(1920 ; 1923 ; 1937)$ se detiene en las problemáticas que la obra de Naharro encuentra frente a la censura inquisitorial responsable del poco influjo que sus comedias habían tenido en el desarrollo del teatro posterior castellano. Escribe sobre la lengua utilizada por los pastores rústicos (1925) y acuña el término "naharresco" (1930-37) para referirse a las obras del s. XVI que comparten los mismos rasgos y que caracterizan la comedia durante el Renacimiento. Por ejemplo, según Gillet, son "naharrescas" las comedias, Vidriana, Tesorina de Jaime de Huete, Turiana y Tidea.

Los cuatro volúmenes de Propalladia and other works of Bartolomé de Torres Naharro incluyen: el Primero: (Bibliography, Collected poems, Diálogo del Nacimiento), el Segundo (Collected Plays), el Tercero (Notes) y el Cuarto volumen (Torres Naharro and the drama of the Renaissance). Este último, quizás el que más informaciones brinda a los fines de nuestro trabajo, toma en consideración los siguientes aspectos: la primera parte («The Past») y la segunda («The Reinaissance») son, como las define Bataillon (1967), la colocación de la obra de Torres Naharro dentro de un vasto panorama de historia cultural; la tercera («The Man and the Artist»), incompleta ${ }^{24}$, es el análisis de la obra teórica y práctica de Naharro. El III capítulo («Torres Naharro’s Dramaturgy»), se interrumpe en el análisis de la práctica dramática de Torres Naharro. El capítulo V («The Plays») había sido realizado hasta el análisis de la Comedia Jacinta. O. H. Green completa el comentario de las comedias y el capítulo VI («Diálogo del Nacimiento»). En fin el capítulo VII («Torres Naharro and the Spanish Drama») debía demostrar como Naharro había

${ }^{24}$ Gillet completa los siguientes capítulos: capítulo I (Biographical Notice), II (The Poems), IV (Chronology). 
fundado el drama español del s. XVI y por consiguiente el del Siglo de Oro. Siguiendo indicaciones, bocetos éditos e inéditos de Gillet, fue completado, como hemos mencionado, por O. H. Green e incluye también sus comentarios.

Algunas de las ideas esenciales que aparecen en el capítulo The Man and the Artist resultan interesantes a los fines de comprender lo que Gillet destaca como popular en Naharro. Vale la pena recordar, además de la amplia información histórica que nos brinda y el minucioso trabajo filológico, algunas de las ideas de su enfoque: el «primitivismo» como idea central para analizar algunos aspectos de las comedias; la herencia medieval hispánica; la herencia clásica y las novedades renacentistas. Nos detenemos en la idea de «primitivismo», que Gillet toma de los estudios de antropología cultural del segundo cuarto del s. XX, y en la herencia medieval.

Según Gillet, pues, el introito de Torres Naharro rompe, tanto con la tradición del prólogo clásico latino, basada en la presentación divertida de los personajes, como con la herencia teatral italiana, desarrollada por Ariosto y Macchiavelli. Torres Naharro piensa en algo «original», donde se mueven un rústico/villano cuyo ritual se parece mucho al de un líder primitivo. En esta introducción al espectáculo, Gillet ve el reflejo de la representación improvisada que se hacía en las casas de labranza típicas de Andalucía durante el período de la cosecha. Por otra parte, el actor, a veces un «clown», a veces un acróbata, es portavoz de un mundo básico, marcado por canciones populares y parodias de la vida cotidiana.

En el teatro de Torres Naharro hay romances y cantares que derivan de la influencia clásica y de la parodia medieval; sin embargo no falta el villancico que resume la idea de la gloria inmortal y de su conquista; esta referencia musical al primitivismo está reforzada por el espíritu natural del rústico. También la canción tiene un papel importante: Torres Naharro utiliza varias canciones, alternándolas entre el fuerte primitivismo, la violencia, el idealismo romántico y los artificios del amor. La función musical se convierte así en el corazón de las comedias, en la expresión lírica de su significado emocional más profundo.

El rasgo cómico es predominante en las figuras del líder ritual, que a veces actúa de «introito-speaker», de bobo o simple, a menudo glotón y grosero, y de 
gracioso, ingenuo aunque sincero. El grupo de los rústicos es numeroso y se destaca por ser despierto; demuestra honor hacia el rey e interés por la Iglesia latina. A veces critica a los demás, pero, sobre todo, representa el instinto natural de la tierra y la materialidad de su proprio entorno humilde. El bobo o simple es constantemente tonto, glotón, muy ingenuo e inocente pero su cabida en la sociedad está marcada por la obscenidad de su instinto natural. El gracioso es un siervo fiel del héroe, a veces un poco burlón y polémico, pero siempre lleno de recursos, cínico, digno y sin ilusiones.

Para Gillet el método creativo de Torres Naharro, se basa en la reconstrucción de la materia primitiva, medieval, clásica y renacentista. Su drama se encuentra a mitad entre lo primitivo y lo mágico. El grupo de los cómicos, es decir la superposición del rústico, del bobo, del simple y del juglar, construyen un mundo real de instintos básicos, materiales y espirituales. El poder de la magia, a nivel de rituales populares, se une al sensualismo de la gente ordinaria y ambos crean una pantalla teatral real que alcanza al público, cada vez más cerca de los orígenes de su tierra, de su pueblo. Sobre todo, según el estudioso americano, Torres Naharro consolida un teatro fundamentalmente popular y permeado por un nacionalismo tanto literario como anti-clásico.

Marcel Bataillon en «Le Torres Naharro de Joseph E. Gillet» (1967) dedica ricas páginas al crítico americano y comparte muchas de la interpretaciones sobre el autor extremeño. Sin embargo, en términos generales, opina que se ha transmitido una imagen distorsionada del autor, sobre todo, en aquellos estudios que tienden a ver en Naharro aspectos parciales de su personalidad: fraile, soldado, enamorado, erasmista, humanista etc. Uno de los méritos del estudio de Gillet, según Bataillon es, como él mismo escribe, el haber superado cierta dicotomía entre lo medieval y renacentista y el haber sabido individualizar los aspectos coexistentes en su obra: «Nous avons trop souvent ressenti, au dénoncé, l'incertitude et la faible valeur explicative des qualifications littéraires tirées de la Periodisierung et du Zeitgeist, des dicussions sur ce qui, chez tel auteur du XV ou XVI siècle, «est médiéval» ou «est renaissance», pour ne pas saluer avec plaisir une originalité du Torres Naharro de Gillet. Il a dépassé cette dichotomie et ces querelles de frontières en partant de la 
coexistence chez un même auteur, et naturellement réparties entre ses créatures, non seulement d'attitudes médiévales et d'attitudes modernes, mais de ce fonds indéracinable de mentalité primitive» (144-145).

Concluimos refiriendo una idea propuesta por Bataillon, a nuestro parecer, más que acertada: aquello que Gillet llama «tendencia a la parodia» en las comedias de Naharro, o aquello que M. Pelayo tacha de «impuros disparates» y «bufonadas», Marcel Bataillon lo define, retomando el término introducido por Valle-Inclán, como «esperpentización». En el carácter cómico-grotesco de las comedias el estudioso francés reconoce aquella deformación de los esperpentos de Valle-Inclán. Algunos componentes y recursos de la estética valleinclaniana recurren en la obra de Naharro. Lo esperpéntico se convierte, según Bataillon, en categoría artística ${ }^{25}$. Esta idea nos remite, una vez más, al lenguaje del realismo grotesco propuesto por Bajtín.

\subsection{La crítica italiana}

En este recorrido a través de los estudios sobre la obra de Naharro queremos dedicarle una atención especial a aquellos trabajos que revelan la estrecha relación

\footnotetext{
${ }^{25}$ Recordamos además los siguentes estudios críticos, entre los años 1920-1960, sobre Bartolomé de Torres Naharro y que revelan aspectos específicos de su obra. El estudioso americano Crawford (1921), dentro de aquella corriente que tiende a estudiar las fuentes literarias en las comedias de Naharro, compara, por una parte, la comedia Calamita con el teatro clásico, el Heautoantimorumenos de Terencio y, por la otra, encuentra atinencias en la tradición italiana, en particular las comedias Calandria de Bernardo Dovizi da Bibbiena y Dolotechne del veneciano Bartolomeo Zamberti escrita en 1504; Romera Navarro (1921), dentro de la corriente de los estudios específicos sobre las comedias, hace un análisis ya considerado clásico sobre la comedia Himenea; Lenz (1923) organiza las obras dramáticas de Naharro siguiendo las fuentes literarias en que se inspira: la tradición peninsular en el Diálogo del Nacimiento, la realidad romana en las comedias «a noticia», recuerdos del mundo italiano en Serafina e Himenea, el mundo de la antigüedad en Calamita y Aquilana; Grismer estudia «Another reminiscence of Plautus in the Comedias of Torres Naharro» (1940); López Prudencio (1934) intenta identificar a los familiares del dramaturgo en su pueblo natal, supuestamente, Torre de Miguel Sesmero; Segura Corvasí (1934) hace un estudio sobre el lenguaje en las obras de Naharro y Legarda (1934) estudia la frase vascuense pronunciada en Tinellaria; Corbató (1950) analiza los rasgos lingüísticos valencianos en la comedia Serafina. Piensa que el conocimiento del valenciano pudo deberse a la relación del autor con personas de aquella ciudad que residian en Roma. RodríguezMoñino (1937) hace una presentación exhaustiva de las ediciones de Propalladia publicadas desde 1517 hasta 1936. Pickering (1956) pone en relación la comedia Serafina con El Conde Alarcos. Otros estudios que recordamos son: María Rosa Lida (1952); Berthelot (1954) ; Ferrario de Ordina (196870).
} 
entre la obra de Naharro y el contexto literario italiano. Importante significado le atribuimos a la interpretación que hacen Benedetto Croce, Pilade Mazzei y Luisa De Aliprandini. Ellos ubican la obra de Naharro en relación a las coordinadas literarias y culturales renacentistas en Italia y proponen, cada uno según la perspectiva teórica en la que obran y en las distintas etapas del s. XX, una lectura interesante de nuestro autor.

Croce escribe entre los años 1883-1906 una serie de artículos $^{26}$ sobre las relaciones literarias entre España e Italia publicados luego en un único volumen, $L a$ Spagna nella vita italiana durante la Rinascenza (1968). En este estudio documenta el peso que tuvo la presencia española en algunas ciudades de la península italiana. Los aspectos que abarca nos ofrecen un espectro amplio de la presencia de la cultura española en la vida italiana del s. XVI. Croce habla de la presencia española en Nápoles y en Roma. Ya desde la llegada de Calixto III, el así llamado 'barbarus Papa' la afluencia española a Italia es numerosa; con el mismo Alejandro VI, Roma se puebla de españoles, tanto que, de cuarenta y tres cardenales que crea durante su pontificado, dicinueve son de su país de origen.

España representa para la cultura humanista de la época, como refiere Croce, la 'ruina' de Italia, que ya había comenzado con la llegada de los Borgia y que se concluye con la invasión española. Refiriéndose a un tratado que permanece desconocido hasta el año 1865, Croce muestra cuál es la recepción de la cultura española por parte de la cultura italiana. El texto es De educatione, escrito por el humanista meridional, Antonio de Ferrariis, llamado Galateo, que declara que lo que entra en Italia es la barbarie española: «Che cosa c'insegnarono essi mai? Non certo le lettere, le armi, le leggi, arte marinara, la mercatura, la pittura, la scultura, l'agricoltura o altra civile disciplina; ma usure, furti, corseggi, schiavitù navale, giuochi, lenocini, amori meretrici, la professione del sicario, il cantare molle e lugubre, le pietanze arabiche, l'ipocresia, i letti soffici e delicati, gli unguenti, i profumi, le cerimonie della mensa e altrettali vanità, degne di essi, che, come tutti i barbari, sono non meno libidinosi che crudeli» (121).

\footnotetext{
${ }^{26}$ Artículos publicados independientemente en los años 1893-1906.
} 
También a través de la lengua y de las costumbres la cultura española se insinúa de forma determinante: se introduce la caza de toros, ya desde Calixto, y las corridas. Una serie de costumbres amorosas se introducen en los hábitos de la galantería, la moda, el amor, los juegos, las fiestas.

En 1949, Croce publica «La Propalladia de Torres Naharro» en la que hace una reflexión crítica sobre la obra de Naharro colocándolo dentro del contexto cultural italiano apenas expuesto. Brinda informaciones sobre la representación de las comedias de Naharro en Roma. Indica por cierto que las obras de Naharro fueron representadas en ocasión de acontecimientos sociales importantes: la comedia Trofea en ocasión de la estadía del embajador de Portugal; Jacinta durante la visita de Isabella d'Este. Con respecto a la comedia Tinellaria cita un fragmento de la dedicatoria a Bernardino Carvajal, en la primera edición suelta de la comedia, en la que demuestra la segura representación de dicha comedia en Roma. Sin embargo, el crítico italiano opina que «nessun italiano mostrò accorgersi della raccolta compiuta dei drammi di costui, la Propalladia, stampata a Napoli nel 1517».

P. Mazzei (1922) sigue la línea de los estudios específicos sobre las fuentes en que se inspiró Naharro para la escritura de sus comedias; asimismo lo venía haciendo Crawford a través de un análisis comparativo entre algunas comedias de Naharro, el teatro clásico, y la producción dramática de tradición italiana. Más tarde L. De Aliprandini (1985) y A. Giordano Gramegna (1986), respectivamente, se ocuparán de profundizar los aspectos que relacionan a nuestro autor con la comedia italiana.

Pilade Mazzei considera que Naharro utiliza las comedias italianas como modelo de las propias. Toma de ellas motivos, colores, sugerencias aunque el espíritu que las anima es fundamentalmente español. Las fuentes hispánicas mencionadas son: el Arcipreste de Hita -sin aducir demasiados ejemplos al respecto-, Juan del Encina y Fernando de Rojas, cuya Celestina habría repercutido en las comedias Himenea y Aquilana y, en menor medida, en la Calamita $^{27}$. Lo que nos sugiere

\footnotetext{
${ }^{27} \mathrm{Al}$ respecto Mazzei escribe: «Alla Celestina il Naharro deve insomma moltissimo; essa fu il modello a cui si sforzò di avvicinarsi nella creazione dei suoi tipi, e siccome quel modello tenne troppo costantemente fitto in mente, senza scostarsene in modo eccessivo, i suoi personaggi si somigliano
} 
Mazzei es que el dramaturgo estaba guiado por el deseo de obedecer a los cánones inviolables de la escritura dramática aunque actuara absolutamente libre de ellos. «Schiavo però non fu di nessuno», escribe Mazzei. En la comedia italiana buscaba tipos, argumentos, motivos pero fundamentalmente un marco, el punto de partida inicial; según las mismas palabras del autor, «il quadro voleva dipingerlo da sé». Y en este sentido fueron importantes la Mandragora de Macchiavelli en las que Mazzei indica algunas semejanzas, como igualmente la Calandria de Bibbiena y los Suppositi de Ariosto. El uso de varias lenguas en las comedias de Naharro son también de procedencia italiana. Resultan aquí importantes las diez farsas carnavalescas de Giovan Giorgio Alione, el plurilingüismo que las caracteriza y la atención desprejuiciada hacia los temas eróticos. La «farsa senese» también juega un rol importante para este autor. Mazzei supone que Naharro haya conocido la farsa que se produce en la ciudad de Siena a finales del siglo XV comienzos del siglo XVI y que de alguna manera exista un parentesco entre las composiciones de Naharro y las toscanas. Efectivamente, los actores senesi actuaban a menudo en Roma. No es de excluir semejante comparación si se tiene en cuenta el código cómico-dramático utilizado que, sin duda alguna, consiste en un mismo lenguaje cómico popular de origen clásico-medieval ya presente, en mayor o menor medida, en las literaturas nacionales de lenguas neo-romances; es decir, la presencia a nivel de superficie de componentes, procedimientos que, de algún modo, revelan, a nivel profundo, la presencia de modelos cercanos o, en el mejor de los casos, comunes. La imagen contextual italiana en la obra de T. Naharro difiere, ampliamente, de la que nos presenta Croce.

Luisa de Aliprandini (1985) en el estudio introductorio a la publicación italiana de la versión suelta de Tinellaria, cuya fecha exacta de edición es incierta aunque seguramente anterior a la edición conjunta de las comedias en Nápoles en 1517- hace un análisis contextual de la comedia Tinellaria destacando la importancia que ocupa el espectáculo teatral cortesano en los primeros años del s. XVI. El mismo

troppo tra loro; essi rispondono costantemente ad un tipo fisso, balzato fuori dalla vita cortigiana, per cui mancano di varietà, né hanno personalità spiccata» $(1922,94)$. 
resulta determinante para comprender no sólo, en qué ocasión y frente a qué público fue representada la obra, sino también cómo fue llevada a cabo la puesta en escena de la comedia. De Aliprandini ve a un Naharro metteur en scène en el palacio de Giulio de' Medici que ofrece un entretenimiento al primo ilustre, el Papa León X, al final de un banquete. Subraya la importancia de la corte romana como centro de recepción y difusión de la cultura renacentista, lugar que atrae a muchos personajes, distintos entre sí, pero que constituyen la polifacética personalidad de la ciudad: «quell'accolita di artisti e di buffoni, di uomini di genio e di furbastri di mezza tacca, di solenni umanisti e di parassiti, che era l'eteroclito ambiente che circondava il gran papa mediceo» ${ }^{28}$.

Igualmente Luisa de Aliprandini considera que la obra de Naharro ha tenido un seguro éxito de público y de lectores en España y en Italia. Contrariamente a lo que opina Benedetto Croce, con respecto a la poca divulgación que habrían tenido las comedias de Naharro en el contexto italiano, la estudiosa italiana demuestra que existen claros puntos de contacto entre la obra de Bartolomé de Torres Naharro y la de Pietro Aretino. Señala que el dramaturgo italiano en su comedia La Cortigiana, como también en las Sei giornate muestra conocer la obra de Torres Naharro, al igual que la de Francisco Delicado. Consecuentemente se detiene en el análisis de los aspectos coincidentes entre algunas jornadas de Tinellaria y escenas de $L a$ cortigiana, sobre todo en aquellas en las que se ilustran las miserias de la vida de los sirvientes y de aquellos que aspiran a ser cortesanos romanos.

Ana Giordano Gramegna (1986) hace un estudio comparativo entre la Calandria de Bibbiena, la Cassaria y los Suppositi de Ludovico Ariosto y La commedia in versi de Lorenzo Strozzi por una parte, Calamita y Serafina de nuestro autor, por la otra. Analiza la estructura teatral, el modelo de lógica de acción, el modelo de estudio de personajes y actores, la construcción dramática del texto y el proyecto del espectáculo llegando a la conclusión que «hay mucho de Italia en Torres Naharro».

\footnotetext{
${ }^{28}$ Giuliano Innamorati, Tradizione e invenzione in Pietro Aretino, cit. en De Aliprandini $(1985,13)$.
} 
Otros estudios más recientes subrayan la importancia del teatro italiano en la producción de nuestro autor, además de los ya mencionados, recordamos que D. McGrady (1983) individualiza como influyente en la obra de Naharro la figura de Poggio Bracciolini; M. Sito Alba (1984), estudia la comedia Soldadesca desde una óptica histórica e intenta interpretar los acontecimientos que allí se representan. Ulysse G. analiza «La Soldatesca de Bartolomé de Torres Naharro et la comédie italienne de son temps» (1987) y T. Cirillo Sirri (1996), en el estudio cuyo título es "Itinerari romani: da Torres Naharro a Delicado" hace un recorrido a través de los textos romanos de estos dos autores "anticonformistas". Hace una comparación entre las descripciones atentas que Pedro de Urdemalas en su Viaje de Turquía ofrece de las ciudades de Nápoles y Roma, por una parte: sus paisajes, monumentos, habitantes, modos de vida italianos, anécdotas y, por la otra, el mayor interés de nuestros autores hacia aspectos concretos de la vida cotidiana y la denuncia de la corrupción moral en la que se encuentra la ciudad papal.

\subsection{El aporte de Gilman y la fundamentación de Zimic}

S. Gilman (1963-64) y S. Zimic (1976-1978) proponen una lectura interesante de la obra de Naharro, aunque opuesta. El primero estudia la comedia Jacinta y destaca la importancia de la ciudad de Roma como refugio de aquellos que huían de España después de la expulsión. Individualiza en los personajes de la comedia a un cristiano viejo, (Jacinto) y a dos conversos (Precioso y Phenicio) y supone que el mismo Naharro fuera un converso. El segundo descubre en Naharro a un intelectual del Renacimiento, activo y crítico ${ }^{29}$.

\footnotetext{
${ }^{29}$ Más recientemente Lihani (1979) ha ordenado y recopilado muchas noticias sobre Naharro, asimismo (1984) ha hecho una series de consideraciones desde el punto de vista social de la comedia Aquilana; Surtz y Weinerth (1982) analizan el elemento cómico de los pastores en la comedia Trofea. Weinerth (1982) hace una aproximación crítica al Diálogo del Nacimiento desde la actitud conversa del autor y coincide con el planteamiento de S. Gilman mencionado anteriormente. Otros estudios valiosos: J. Oleza $(1984,2002)$ y el equipo de sus colaboradores, presentan sobre la obra de Naharro argumentos de gran rigor crítico; Heugas (1985), hace un recorrido a través de la obra dramática de
} 
Stanislav Zimic propone, en definitiva, rebatir los conceptos de «primitivismo» y «medievalismo» introducidos por Gillet. Los mismos inducen a una interpretación distorsionada del pensamiento de Torres Naharro. Según el crítico existe una unidad de pensamiento en todas las obras del extremeño y que él identifica con el erasmismo. La visión firme del autor sobre lo moral y lo inmoral en el hombre y en la sociedad se transparenta de igual manera en todas sus obras. A través de un estudio comparativo de la obra de Erasmo de Rotterdam -Enchiridion, Querela pacis (1517, unos de los muchos tratados en que Erasmo condena la guerra), Dulce bellum inexpertis (publicado en la edición de 1515 de los Adagia) Julius exclusus, etc.- y de Torres Naharro -Diálogo del Nascimiento, Sátira, Concilio de los galanes y cortesanas de Roma, invocado por Cupido, Cápitulo III- Zimic intenta demostrar su tesis. Todas las ideas religiosas y morales que encontramos en Naharro brotan de la misma tradición cristiana de la que se nutre Erasmo. Torres Naharro, según Zimic, no era más medieval que Erasmo mismo en sus actitudes religiosas. «Las fuentes literarias», escribe Zimic, en Naharro son «un instrumento eficaz de la nueva idea» $(1976,49)$. «Parecen inalteradas, pero el contexto en el que se emplean disipa esa impresión». «La presencia de algún elemento literario tradicional inalterado en la obra de Naharro, no puede considerarse automáticamente -pecado frecuente de la crítica de Gillet- como peso muerto de una ciega imitación. El uso de las fuentes literarias tiene comúnmente una auténtica justificación». «(...) Se le atribuye a Torres Naharro un apego tan incondicionado al tópico literario tradicional que se llega a negarle interés en ese mismo «tópico», cuando forma parte de su vida actual» (50).

Escribe Zimic que pocos autores de la época son tan «fervorosos» como lo es Torres Naharro con respecto a los problemas religiosos, morales y sociales que trata. Critica la corrupción eclesiástica, las formas externas de la religión y exalta el

Naharro, deteniéndose en aspectos innovadores de su teatro (personajes arquetípicos, tratamiento de temas como amor/honor, intriga secundaria, sentido del humor agudo, ironía), aspectos ya en parte introducidos por Gillet en su trabajo sobre Propalladia; Cox Davis (1988) estudia el componente tragicómico de Propalladia; Teijeiro Fuentes (1990), estudia la comedia Calamita en el contexto extremeño y en El teatro en Extremadura en el s. XVI (2002) dedica a Torres Naharro el II capítulo de su texto (83-203); Laitenberger (1990) hace un estudio sobre «Bartolomé de Torres Naharro, poeta y dramaturgo del amor cortés». 
sentimiento religioso interior, inspirado en la vida ejemplar de Cristo: aspiración a relaciones humanas, caracterizadas por la sencillez, probidad, caridad y justicia. Esta postura representa un concepto fundamental y coherente y «no una taracea accidental e imponderada de tópicos tradicionales, según se viene pensando» (94). Por lo tanto Erasmo representa la inspiración fundamental de Naharro y el autor extremeño «uno de los primeros españoles que se afiliaron con entusiamo y por completo al pensamiento del gran humanista de Rotterdam» (95).

Amplias páginas le dedica Zimic al análisis de las comedias Soldadesca y Tinellaria, que retomaremos en varios puntos del trabajo. Nos resulta interesante cerrar esta página con una consideración de Zimic: «...ningún coloquio de Erasmo, por genial que sea en otras cualidades, tiene tan altos méritos artísticos como, por ejemplo, la comedia Soldadesca o la Tinellaria. Esta opinión, que sin duda parecerá muy extraviada al afiliado de la crítica de Menéndez Pelayo y Gillet con respecto a Torres Naharro, trataremos de ilustrarla convincentemente en los capítulos siguientes» (100). 
Capítulo II 


\section{$\underline{\text { Naharro preceptista }}$}

\section{Intertexto y relaciones interculturales en Torres Naharro}

Los estudios sobre la dramaturgia de Torres Naharro ofrecen, como hemos visto, una visión amplia y diversificada del autor y su obra, a veces resaltando los aspectos tradicionales o, dicho junto con Gillet, «primitivos» o «medievales» de sus textos, otras veces, aquellos innovativos o «renacentistas». En realidad, conducir a Torres Naharro hacia una Edad Media de la cual su obra teatral conserva, parcialmente, algunos elementos o proyectarlo hacia un Renacimiento consolidado significa adoptar una actitud desviante frente a su interpretación, sobre todo, si no se toman en cuentan aquellos aspectos que hacen a la cultura de representación y a las contigüidades contextuales.

García de Enterría, lo mencionamos en la introducción, observa el «auténtico juego intertextual que es la literatura popular: las interacciones se dan continuamente entre lo oral y lo escrito, entre lo letrado y lo iletrado, entre lo visual y lo auditivo, y, en conclusión, -escribe- se podría hablar de un juego intercultural que se hace más visible que en cualquier otra parcela de lo literario» $(1995,10)$. Dos cuestiones importantes antes de continuar: en el caso de Torres Naharro, lo intertextual e intercultural se amplifica ante la escritura de textos teatrales que adquieren mayor significado con relación al contexto en el que se representan, y, en este momento de la historia, el teatro - en cuanto representación- tiene una función cultural específica, como veremos a continuación. La segunda cuestión remite a la expresión literatura popular apenas citada, que nos obliga a recordar lo siguiente: el tema de la literatura popular, y de lo popular en general, es ante todo inmenso e inabarcable en todas sus facetas -hemos visto cuantas dificultades encuentra el crítico en el momento de su 
definición; en el caso de Torres Naharro nos encontramos frente a la figura de un letrado que se «apropia» del lenguaje de la cultura popular. Esta, lo repetimos, efectúa una captura simbólica sobre el letrado para irrumpir en la cultura oficial; por otra parte, las jerarquías, los ritos de la cultura oficial entran, mediante el mecanismo de la inversión y la ridiculización grotesca, en la cultura popular. ¿Por qué esta precisación nuevamente? Bajtín en su estudio especifica el lugar que ocupa la figura del letrado respecto a la intelección de la cultura popular, en cuanto trasmisor, mediador, «filtro» (Ginzburg) de una cultura y es a partir de esta visión del letrado (que es Torres Naharro) que trataremos de individualizar las circularidades, los «intercambios subterráneos» entre la cultura alta y la cultura popular que caracteriza tanta literatura renacentista y que se hace más evidente ante la escritura de un dramaturgo.

Para denotar los espacios contiguos en las comedias romanas en cuestión, los términos intercultural e intertextual, y todo lo que los mismos implican, nos impulsan a organizar nuestro trabajo siguiendo dos trayectorias complementarias. Por una parte, lo intercultural remite a la concepción del hecho teatral como «complessità culturale di cui esso è coagulo e portatore» (Cruciani, 1983, 15) y en este sentido trataremos de denotar la especificidad del espectáculo a comienzos del s. XVI en Roma; lo intertextual, en cambio, remite a aquella pluralidad heterogénea de formas de escritura, suma de lenguajes múltiples y variados, que vuelca, cada una, su propia imagen de lo teatral y en la que se entrecruzan elementos del pasado como del presente.

Las palabras y los conceptos en torno a teatro y comedia -que Naharro intenta definir en su Prohemio- son, en la época que nos ocupa, imprecisos y vagos; por otra parte, las formas de representación son múltiples y no constituidas en sistema o institución. Los oficios del teatro no existen como tales sino en función de procedimientos expresivos más amplios y de organismos de producción distintos entre sí ( Cruciani, 1983, 7) . $^{30}$ Para estudiar el teatro de comienzos del s. XVI, y en

\footnotetext{
${ }^{30}$ « (...) la recitazione è un epifenomeno del raccontare e dell'oratoria, la scena e la sala sono funzioni dell'archietto apparatore, le costruzioni iconologiche e simboliche lo sono del letterato cortigiano, con
} 
particular el teatro italiano en cuyo contexto obra Naharro, es necesario, por lo tanto, tener en cuenta que el mismo es «parte activa y producto dialéctico de la rica y múltiple cultura de representación construida en el Renacimiento» (Ibid.) ${ }^{31}$.

\section{Todo texto dialogado se llamaba «comedia»}

En el s. XV y XVI la literatura castellana no se expresa a través de una terminología dramática sistematizada. Una pluralidad heterogénea de formas de escritura ofrece su propia imagen de lo teatral. Los autores utilizan varios términos para denominar sus piezas. Los términos comedia y tragedia aparecen con frecuencia; sin embargo, muchas son las composiciones que superan la tajante división impuesta por la preceptiva antigua: tragicomedias, cantos, farsas, églogas, coplas, coloquios, romances, autos, y tantos otros dominan el repertorio dramático. Esta pluralidad de denominaciones plantea en términos preceptísticos la cuestión en torno a qué tipo de composición dramática respondía la calificación de comedia. En la misma Celestina se discute acerca de la definición de los términos comedia, tragedia y tragicomedia. En sus múltiples ediciones, fue a su vez llamada comedia o tragicomedia, y el mismo autor en las primeras páginas del texto reflexiona sobre estos dos términos: «¿quién negará que haya contienda en cosas que de tantas maneras se entiende?». «Otros han litigado sobre el nombre que no se había de llamar comedia, pues acaba en tristeza, sino que se llamase tragedia. El primer autor quiso dar denominación del principio, que fue placer, y llamóla comedia: yo viendo estas discordias entre estos extremos, parí ahora por medio la porfía y llaméla tragicomedia» ( Rojas, 2000, 81).

inserti delle arti di intrattenimento, dai giullari ai musici alla cultura del racconto e dei dialoghi» (Cruciani, 1983, 7).

31 « (...) occorre restuirgli il suo essere parte attiva e prodotto dialettico della ricca e molteplice cultura di rappresentazione costruita nel Rinascimento (...) » (Ibid.). 
El historiógrafo veneciano Marin Sanudo ${ }^{32}$ (Ulysse, 1987, 93) atestigua que todo texto que presentara una estructura dialógica era llamado comedia. Bajo este mismo título de comedia se encontraban los diálogos, églogas, tragicomedias, novelas. Anota que junto a los textos teatrales, escritos para ser recitados bajo el título de comedia, había églogas rústicas, farsas, y hasta composiciones dialogadas que podían al máximo prestarse a una lectura animada, asimismo obras que tenían un carácter narrativo acentuado. La extensión de estos textos variaba al infinito: algunas comedias seguían el ejemplo latino y estaban divididas en cinco actos, otras en un acto, sin división de escenas. Se tendía a llamar comedia a todo texto en prosa o en verso que tuviese una estructura dialogada.

$\mathrm{Si}$ hacemos un repaso rápido de los textos con que tropezamos en las primeras décadas del s. XVI en lengua castellana, reparamos en la existencia de églogas, diálogos, autos, comedias y novelas y los límites de demarcación de diferencias y similitudes entre los mismos son difíciles de determinar. Un ejemplo pueden ser todas aquellas obras de 'derivación' celestinesca que en algunos casos encontramos bajo el título de comedia, pero también de auto, diálogo o novela. Uno de los casos más conocidos es, quizás, el de la obra La Lozana andaluza. Estudiosos que se han dedicado a profundizar el análisis de este texto individualizan, por una parte, no sólo parecidos con la estructura celestinesca sino también elementos propios del género picaresco y, por la otra, encuentran parentescos con las anónimas comedias Thebayda y Serafina ${ }^{33}$ y no dudan en enmarcarla dentro de un contexto en directa relación con el teatro, poniendo de relieve el diálogo dramático con el cual está compuesta. F. Cruciani (1987) no duda en absoluto en hablar de La lozana andaluza como de una comedia. Todo esto nos indicaría, en términos normativos y convencionales, una cierta fragilidad, pero pone en evidencia la complejidad real del problema en cuestión y nos muestra la imposibilidad de enfocar el mismo a partir de presupuestos excluyentes.

\footnotetext{
${ }^{32}$ Marin Sanudo: Venecia 1466-1536, historiógrafo. Compuso varias obras históricas y los Diarii, 58 vols: son narraciones detalladas de hechos políticos, militares, económicos y de costumbre de la vida veneciana desde 1496 al 1533.

${ }^{33}$ Las comedias Thebayda, Ypólita y Seraphina aparecen publicadas en Valencia, 1521.
} 
Otro ejemplo, tal vez menos conocido, es el Auto de Clarindo, de autor anónimo, también de derivación celestinesca con respecto al argumento tratado, al desarrollo del conflicto y al mismo tipo de personajes, pero que es presentado como un auto con una estructura tripartita que de alguna manera, según algún crítico 'perspectivista', anticipa la división en tres actos propia de la comedia del Siglo de Oro.

Siro Ferrone, en la tentativa de estudiar los orígenes de la commedia dell'arte introduce el concepto de «procedimiento sincrético» en el que con criterio flexible, e incluyendo actividades literarias y no-literarias aparentemente muy lejanas entre sí, evidencia los elementos heterogéneos que hacen al teatro del Renacimiento. Escribe: «Siamo dunque nel 1545 come data di comodo. Prima di allora era stata la letteratura ad offrire ospitalità agli attori. Le composizioni di Pietro Aretino, di Macchiavelli, dell'Ariosto e dello stesso Ruzante, avevano applicato per la prima volta i canoni retorici della commedia a una materia desunta dalla società contemporanea. La commedia era una delle tante forme restaurate dall'archologia umanistica. La cosidetta "invenzione", o restaurazione, del Teatro che si produsse tra XV e XVI secolo contemplò, insieme al ripristino del luogo teatrale omologato da Vitruvio, anche il riordino della drammaturgia tragica, comica e pastorale. Dentro la casa intitolata "commedia" erano state chiamate a raccolta le piú diverse espressioni della cultura romanza. $\mathrm{Fu}$ un procedimento sincretistico che aveva come riscontro figurativo, almeno a guardare i frontespizi delle edizioni plutine di Melchiorre Sessa e Pietro de'Ravani (1518), la difficile intrusione delle mansiones medievali nella scena prospettica di fonte classica. Cosí, nella letteratura drammatica voluta dalla riforma degli umanisti, si erano introdotti, senza destare scandalo, i buffoni, i giullari, i comici solitari della tradizione medievale e municipale; costoro avevano portato sulle spalle le masserizie del loro repertorio: le voci monologanti e cantanti, la destrezza fisica, i contrasti in rima, le pantomime giullaresche, uno straccio di storia capace di tenerle unite» $(1985,7)$.

La comedia, al fin, se plantea como un producto literario heterogéneo y múltiple: las sacras representaciones, la comedia humanística en latín, teatro 
goliárdico, representaciones juglarescas, tradición dramática y poética de tipo rústico y campesino, formas dramáticas relacionadas con la celebración del carnaval, formas literarias distintas, modernas y contemporáneas, el componente clásico latino, el componente novelístico, el componente realista ${ }^{34}$.

Los prejuicios hipotéticos de una "pureza" artística, segura, canónica, por lo que se refiere a los géneros, sucumben a la realidad del hecho artístico marcado por las condiciones históricas, que no pueden no dejar sus huellas, no sólo en los aspectos contenidistas, sino también en los formales. Las prácticas artísticas no renuncian, no pueden hacerlo -tampoco en términos de procedimientos literarios- a reflejar y a constituirse en un cierto funcionamiento del mundo.

La literatura renacentista, como sabemos, basa su experiencia en el clasicismo, pero, por otra parte, se apoya en todas aquellas formas de rebelión contra el clasicismo como expresión de la crisis existente en la relación entre humanismo y pensamiento cristiano.

Por ello nos parece interesante el planteo de procedimiento sincrético del cual habla Ferrone, procedimiento sincrético en todas las direcciones. Se trata, pues, en el caso del teatro, de un sincretismo en el que convergen una multiplicidad de factores, tradicionales y/o innovadores, la consideración de fenómenos nuevos, tanto en la práctica teatral y en la relación texto-guión, espectáculo-espectador, como, asimismo, en una serie de nuevas relaciones o contigüidades contextuales. La heterogeneidad, pues, no está tanto en el resultado del nuevo producto como tal, objeto de estudio preciso y definido, cuanto en los elementos variados, específicos y contextuales, que tienden a configurarlo. Poner el acento, de un modo excluyente, en algunos factores, en desmedro de otros, significaría, a nuestro entender, desvirtuar nuestro objeto de estudio, o, en el peor de los casos, perdelo de vista.

\footnotetext{
${ }^{34}$ Estos son algunos de los elementos que Paolo Bosisio, en el estudio Popolaritá e classicitá nel teatro comico del Cinquecento (1975), dedicado a lo popular y a lo clásico en el teatro cómico del Renacimiento y en particular al estudio de los componentes fundamentales que llevan a la conformación de la comedia, indica como expresiones teatrales preexistentes e intrínsecas a este género renacentista
} 


\section{El Prohemio: de la práctica a la teoría}

En el Prohemio, Torres Naharro se ocupa de formular un modelo sistemático de composición de comedias. Estas consideraciones introductorias son los más antiguos preceptos dramáticos escritos en lengua castellana y su originalidad hace de este texto uno de los más interesantes documentos de teoría dramática renacentista. Naharro reflexiona sobre la esencia del arte dramático y trata de explicar las leyes y los principios que rigen la estructura de la comedia. Une los aspectos teóricos y prácticos de su creación exponiendo una serie de problemas teóricos: la definición de la comedia, la división en cinco actos, el número de personajes, el decoro, la división de las comedias en «a noticia»-«s'entiende de cosa nota y vista en realidad de verdad»- y «a fantasía»-«de cosa fantástiga o fingida, que tenga color de verdad aunque no lo sea»-, y las partes que la constituyen.

El concepto de comedia que propone Naharro es esencialmente clásico. Sin embargo, la fuerza motriz de su teoría dramática es el deseo de superar las convenciones clasicistas. Al teorizar, Naharro no adopta ciegamente la tradición sino que la adapta a sus propias ideas. Algunas veces hasta la rechaza deliberadamente contraponiendo a ciertos modelos antiguos sus propias definiciones. Contrariamente a la tendencia a la codificación del teatro, propria de las teorías renacentistas, Naharro relativiza la norma y concede explícitamente cierta libertad artística a los dramaturgos. Elude, además, la confrontación con la tragedia y destaca la comedia, la clasifica y define.

Fabrizio Cruciani y Daniele Seragnoli (1987, 9-10) ilustran un aspecto referente a las costumbres y a la cultura cortesana de la época que denota el significado del hecho teatral en el s. XVI. Para ellos, el teatro del Renacimiento es el origen del teatro moderno, pero, más que la reconstrucción de un hecho, el objeto de una historia del teatro renacentista es la complejidad cultural de la cual el mismo es núcleo y transmisor. El banquete es el núcleo central en torno al cual se desarrolla la 
vida social en estos años. Este elemento cultural tan claramente definido es el que permite individualizar, de alguna manera, la función del acto teatral dentro de la cultura cortesana renacentista. No es un caso, según los autores mencionados, que Erasmo de Rotterdam, en el divertido diálogo intitulado La gran cena de sus Colloquia familiaria haga referencia a la comedia para exponer los elementos necesarios para el éxito seguro de una buena cena.

Y tampoco es un caso que Bartolomé de Torres Naharro, en ese texto introductorio fundamental para el desarrollo de la dramaturgia española renacentista, es decir el Prohemio a Propalladia, utilice la comparación entre aspectos referidos a la comida y al arte teatral para exponer los temas que presentará en su libro. Y quizás esta analogía entre «comedia» $\mathrm{y}$ «comer» no resulte del todo impropia. El banquete renacentista es la situación cultural, antropológica y social de más amplia difusión en la época, además de ser un lugar privilegiado para el desarrollo de las artes del entretenimiento. «La orden del libro, pues, que ha de ser pasto espiritual, me pareció que se debía ordenar a la usanza de los corporales pastos $(\ldots) »(7)^{35}$, escribe Naharro. El banquete renacentista, lo repetimos, es un lugar privilegiado para el desarrollo de las artes del entretenimiento. «La situazione degli studi ci consente solo poche e piccole certezze: il teatro del Rinascimento è 1'“origine" del teatro moderno, il che significa che vi si coagulano elementi preesistenti e sperimentazioni e tensioni verso possibilità, ma con un qualcosa che chiameremo ancora salto di qualità: nel Rinascimento si "inventa" il teatro in senso moderno, e quindi il Teatro non è qui ancora definito. Il teatro del Rinascimento non nasce dal teatro ma dall'incontro dialettico e complesso tra una idea-forma che è stata elaborata e delle pratiche: ed è teatro epifita, che si nutre della cultura di cui è parte e che esprime. Oggetto di una storia del teatro rinascimentale è forse, piú che la ricostruzione dell'evento, la

\footnotetext{
${ }^{35}$ A continuación, todas las citas de las obras de Bartolomé de Torres Naharro son escogidas de la edición de Propalladia de M.A. Pérez Priego (1994). El Proemio ocupa las páginas 7-9.

Escribe Naharro: «(...) conviene a saber: dándoos por antepasto algunas cosillas breves, como son los Capítulos, Epístolas, etc., y por principal cibo las cosas de mayor sujeto, como son las comedias; y por pospasto ansí mesmo algunas cosillas, como veréis. Cuanto a lo principal, que son las comedias, pienso que debo daros cuenta de lo que cerca de ellas me parece, no con presunción de maestro, mas solamente para serviros con mi parecer, tanto que venga otro mejor»
} 
complessitá culturale di cui esso è coagulo e portatore» $(1987,11)$. Concluyen estos autores escribiendo que si Torres Naharro nos dice que «comedia» deriva de «comer», no resulta de ello un error de etimología, sino que encontramos allí el problema y la indicación de la contigüidad y de las intersecciones entre banquete y comedia (11).

La obra literaria de Torres Naharro aparece publicada en un solo volumen cuyo título es Propalladia, en honor de Palas, epíteto de Atenea, la diosa griega de las artes. El mismo autor se ocupa de recordarnos que «las más destas obrillas andavan ya fuera de mi obediencia y voluntad» (7). Asimismo dice que esta recopilación de sus producciones escritas son el «bajo presente de mis primeras vigilias» (7).

Escribe el autor: «Comedia, según los antiguos, es civilis privataeque portunae, sine periculo vitae comprehensio, a diferencia de tragedia, que es heroicae fortunae in adversis comprehensio. $\mathrm{Y}$ según Tulio, comedia es imitatio vitae, speculum consuetudinis, imago veritatis. Y según Acrón poeta, hay seis géneros de comedias, scilicet: stataria, pretexta, tabernaria, palliata, togata, motoria, y cuatro partes, scilicet: prothesis, catactrophe, prologus, epithasis, y como quiere Horacio, cinco actos, y sobre todo que sea guardado el decoro, etc.». Antes de exponer sus ideas sobre la comedia, Naharro propone un interminable recorrido a través del tradicionalismo conceptual en el que el autor pone de manifiesto su conocimiento de los autores clásicos y de sus comentarios. Gillet demuestra, sin embargo, que las citas no son tomadas directamente de las fuentes originarias; al contrario Naharro toma los datos de Familiaria Praenotamenta (Gillet, 1951, III, 22-26) de Jodocus Badius.

La abreviatura etc. con la que Naharro termina repentinamente su exposición de citas clásicas muestra su actitud hacia los clásicos y anuncia el tono con el que continuará su razonamiento. «Todo cual me parece más largo de contar que necesario de oír. Quiero ahora decir yo mi parecer, pues el de los otros he dicho» (8). Cumple con la tradición y pasa a la formulación de su teoría. «Y digo ansí: que comedia no es otra cosa sino un artificio ingenioso de notables y finalmente alegres acontecimientos por personas disputado» (Ibid.). Centra, como vemos, su atención en la representación divertida de los acontecimientos, y deja de lado aquellas «cosas bajas y pequeñas» 
como asimismo el «bajo y homilde estilo» que habían interesado a los comentaristas dramáticos del s. XV. Se percibe la exigencia que siente de alejarse de todo aquel corpus programático que había encontrado su origen en la Poética de Aristóteles. Y en este sentido el autor no habla de comedia en relación a su opuesto, que sería la tragedia. Al contrario la eleva a un primer plano donde la vemos como un género dignificado en el cual encontramos a un «artificio ingenioso, de notables y finalmente alegres acontecimientos por personas disputado» (Ibid.). Observamos que los adjetivos «ingenioso» $\mathrm{y}$ «notables» corresponden más bien a la definición de tragedia que no a la de comedia. El paso hecho por Naharro inicia un proceso de redefinición del género: «La división de ella en cinco actos, no solamente me parece buena, pero mucho necesaria, aunque yo les llamo jornadas porque más me parecen descansaderos que otra cosa, de donde la comedia queda mejor entendida y recitada» (Ibid.). No sólo toma distancias de la preceptiva dramática clásica, sino que también presenta nuevos aspectos que modificarán la futura composición de la comedia. La clásica división en cinco actos, de acuerdo con la preceptiva horaciana «neve minor neu sit quinto productior», será estructurada por él en el marco de jornadas. La «jornada»-como también la «jornadeta» que aparece en el introito de la comedia Serafina- es un italianismo que, sin embargo, no corresponde al significado de la palabra italiana «giornata». Las interpretaciones en torno al significado del término «jornada» han sido varias. Fundamentalmente nos referimos al análisis llevado a cabo por Gillet. El argumento de Naharro es: «yo les llamo jornadas porque más me parecen descansaderos que otra cosa», es decir, momentos/entreactos que facilitan el descanso del público («de donde la comedia queda mejor entendida»), como por los actores («recitada»). Según la propia explicación, por lo tanto, los descansaderos no son las jornadas mismas, sino las pausas entre ellas. También se podría considerar al término «descansaderos» como participio con función adjetiva, expresando entonces la cualidad del verbo descansar. En este caso hay que relacionarlo con los «cinco actos» y la interpretación sería: la división de la comedia en cinco actos no me parece solamente buena, sino muy necesaria; aunque yo les llamo jornadas, porque me parecen más descansaderos («reposantes») que otra cosa. Gillet (1951, III, 22-26) 
considera esta interpretación menos aceptable, aunque, según nuestra opinión coherente. Naharro, pues, destaca la continuidad de la acción dramática (Zimic, 1977, 121) a través de la unión entre las jornadas y la participación activa del auditorio a través de la reflexión entre una «jornada» y la otra («la comedia queda mejor entendida»).

Naharro no está interesado en los preceptos clásicos y lo dice explícitamente. Tiene bien claro el significado de la acción en la representación dramática y esto se revela en la importancia que le da al decoro. Éste representa uno de los aspectos más importantes en la composición de comedias: pretende un adecuado comportamiento de las distintas figuras dramáticas en el ambiente general de la obra. «El decoro en las comedias es como el gobernalle en la nao, el cual el buen cómico siempre debe traer ante los ojos. Es decoro una justa y decente continuación de la materia, conviene saber: dando a cada uno lo suyo, evitar las cosas impropias, usar de todas las legítimas, de manera que el siervo no diga ni haga actos del señor, et converso» (Ibid.). Para que la comedia tenga éxito, o esté bien representada, es necesario respetar la acción y la realidad de cada personaje, su decoro, «el cual el buen cómico siempre debe traer ante los ojos»». ¿Quién es el buen cómico? El metteur en escène, como lo supone Luisa de Aliprandini, respecto a la puesta en escena de la Tinellaria. Naharro tiene en la mente a un «director», no sólo a un escritor de comedias sino también a un coordinador, llamémosle así, de la puesta en escena del espectáculo.

Torres Naharro no introduce restricciones con respecto a la extracción social y al número de los personajes. No sigue el precepto horaciano «nec quarta loqui persona laboret», según la cual el número cuatro no se refiere sólo a los interlocutores de un mismo diálogo, sino también al número máximo de los personajes en la escena. Badius por otra parte, escribe: «Plures autem quam quattuor esse non possunt si quarta fuerit rarissime loquentur. Unde dicit Horatius in libro de poetica» (Gillet, 1951, III, 73-76). Naharro propone un número limitado de personajes, entre seis y doce, cosa que además él mismo respeta en la composición de sus comedias, excepto en la Tinellaria en la cual encontramos a veinte personajes. Las personas de la comedia, 
según él, «no deben ser tan pocas que parezca la fiesta sorda, ni tantas que engendren confusión» (8).

«De dónde sea dicha comedia y por qué, son tantas opiniones que es una confusión». Esta frase de Naharro ejemplifica lo expuesto anteriormente respecto a la pluralidad de formas de escritura -tragicomedias, cantos, farsas, églogas, coplas, coloquios, romances, autos- que se denominaban comedias.

La división que el extremeño hace de las comedias es: «comedias a noticia» y «comedias a fantasía». Ambas palabras, noticia y fantasía son castellanas, pero «a fantasia» proviene del italiano: di invenzione, seguendo l'immaginazione, normalmente utilizado con el pronombre intercalado, a loro fantasia. La connotación dominante en la definición de Naharro es probablemente musical, tal como se establece en Europa en el s. XVI. Designa las imaginaciones musicales en ciertas composiciones instrumentales basadas generalmente en un tema vocal, como por ejemplo ricercario, tiento, motete, glosado, y especialmente fantasia, composición instrumental cerca de la improvisación. "A noticia» es probablemente un hallazgo narrahesco, invención italianizante según el modelo de «a fantasía». Esta división original del autor y su explicación correspondiente se pueden interpretar del siguiente modo: «comedia a noticia», es la comedia sobre hechos que acontecieron en la realidad, «comedia a fantasía», comedia sobre hechos creados por la imaginación. Naharro se apoya como punto de partida en las teorías heredadas de la Antigüedad y desarrolla a partir de las mismas esta división en obras que reflejan la realidad y otras que son fruto del ingenio del autor, pero que no tienen, necesariamente, una correspondencia inmediata con la realidad, «que tengan color de verdad aunque no lo sea». Esta distinción nos lleva a suponer -según el grado de mimetismo que tiene cada comedia- que Naharro valora más lo puramente teatral y se opone a los criterios clasicistas habituales que distinguen las comedias por motivos externos, como la edad del protagonista o la localización y el tiempo de la acción etc. (stataria, praetexta, tabernaria, palliata, togata, etc.). Y es así como se presentan divididas sus comedias en Propalladia. 
Por último considera que la comedia debe tener dos partes que son el «introito» y el «argumento». Es decir, sigue dejando de lado los modelos clásicos anteriormente citados que proponían cuatro partes, y deja que cada uno con libertad decida al respecto. «Partes de la comedia, ansí mesmo bastarían dos, scilicet: introito y argumento. Y si más os paresciese que deuan ser, ansí de lo uno como de lo otro, licentia se tiene para quitar y poner los discretos» (9).

En las comedias clásicas y en la de los autores italianos del s. XVI el «introito» tiene la función de introducir el espectáculo divirtiendo al espectador con momentos de burlas, payasadas, chistes picantes tendientes a hacer críticas incisivas sobre el entorno social. En general, un rústico, que se expresa en sayagués (excepción hecha de la comedia Tinellaria), presenta a los personajes, hace, algunas veces, la apología del autor, y usa un tono desenfrenado para atraer la atención del auditorio. Hace también el resumen de la acción que se desarrolla a continuación del introito («argumento»), e indica el título, número de actos y para terminar, la promesa de proporcionarle diversión al público y la incitación a seguir atentamente la función.

El núcleo central de la narración, en los introitos, son la glotonería y el buen beber de los pastores en presencia de la corte. La comicidad del texto se encuentra depositada en la exaltación del tema de los instintos básicos del ser humano. El autor tiende a ridiculizar al personaje creando un procedimiento en el que adquiere importancia lo fisiólogico. Se trata de un tipo de personaje incapaz de acceder al mundo de lo espiritual. Y en lo fisiológico entran, no sólo las referencias a alusiones de las partes bajas del cuerpo, sino también a aspectos referidos a la glotonería, al comer grosero, al beber mucho etc. «El villano 'bobo' es divertido por su pesadez de pensamiento, la falta de urbanidad, la ineptitud para los refinamientos de la vida intelectual o sentimental, su apego terco a la tierra. Así nada ilustra mejor lo cómico villano sino el significado de este vocablo "rústico"» (Salomon, 1985, 54).

El aspecto 'sociológico' de la comicidad campesina se desarrolla en dos planos: por una parte, el personaje ridiculizado que adquiere significado por el contexto en el que está actuando; por la otra, la relación de mecenazgo en la que se 
encuentra el poeta con el señor aristocrático. Los autores teatrales renacentistas siempre utilizan a sus personajes para alabar al señor y, a su vez, pedir subsidios.

La forma de comicidad propuesta por el pastor de origen ya clásico grecoromano, llega hasta el teatro del siglo XVI a través también de las prácticas teatrales medievales y está presente de manera definida en la obra de Naharro. En todos sus comedias encontramos esta forma de introducción, externa a la representación. El pastor, en su performance cómica determina los límites del espacio de la ficción teatral. A través de la narración en primera persona de hechos referentes a su experiencia personal atrae la atención del público creando una relación directa entre el mundo de la cotidianidad y el mundo de la ficción. «Si bien el saludo del pastor a la sala rompe aparentemente con el juego de la ficción al quererse él acercar o asimilar a los propios espectadores realizando un falso diálogo con ellos, la diferencia de estado social del rústico (que además aparece medio animalizado o bobo) hace que las distancias no se aproximen y se mantenga la división preestablecida entre el espacio de la representación (ficción) y el de los espectadores (realidad). Es decir, se mantiene siempre la ficción representativa desde el inicio del espectáculo, y el personaje que recita el introito no hace más que preparar al auditorio para que concentre su atención en lo que acontecerá inmediatamente después, sobre las tablas, con un espíritu distendido, jovial y alegre, puesto que lo que van a ver no es ni más ni menos que una comedia» (Canet, 2001, 43-44).

El «argumento», en cambio, es el desarrollo mismo de la fábula. En Naharro cambia la repartición; el término argumento no se refiere a la parte central de la acción, dado que él mismo lo utiliza para designar la segunda parte del introito, y es una exposición resumida de la acción. Todas sus comedias empiezan con una introducción, bajo un único título «introito y argumento».

Es significativa la observación del preceptista sobre el «quitar y poner» partes de la obra. Aunque utiliza el concepto clásico de mesura, «discretos», con este llamado de atención a los creadores, Naharro muestra su actitud de renovador sereno y lleno de confianza en sí mismo. 
«Ansí mesmo hallarán en parte de la obra algunos vocablos italianos, especialmente en las comedias, de los quales convino usar haviendo respecto al lugar y a las personas a quien se recitaron». Cierta ironía acompaña esta frase. El italiano que aparece en boca de los personajes de las comedias tiene una función de burla, no tanto de respeto hacia el oyente, no trasciende ninguna cortesía en la utilización del italiano. Además no es la única lengua que se agrega al castellano. Por otra parte, sabemos que el personaje del español bruto e ignorante era típico en las comedias italianas. Concluye Naharro «Algunos dellos he quitado, otros he dexado andar, que no son para menoscabar nuestra lengua castellana, antes la hazen más copiosa».

Las comedias de Naharro siguen los criterios de composición expuestos en el Prohemio de Propalladia: introito, argumento y cinco jornadas.

Respecto al «género», probablemente, Torres Naharro no introduce grandes novedades: las comedias de Plauto y de Terencio, como asimismo la comedia humanista italiana, son para él un referente; lo mismo valga para los preceptos de Horacio. Sus mismas comedias forman parte de aquello que Luisa de Aliprandini, llama «il filone nascente in Italia del teatro comico rinascimentale, parallelo e conseguente al recupero del teatro classico» $(1985,13)$.

Uno de los aspectos más significativos, quizás, de sus textos es que sus comedias están escritas en castellano -y con ello no queremos decir una obviedaden el tradicional octosílabo rimado, y no en italiano o en el latín de los humanistas. Un mosaico de personajes habla en esta lengua y forma parte de un nuevo panorama o ambiente ciudadano, en el cual no sólo se expresan los tradicionales pastores o rústicos del pasado (o de sus contemporáneos) sino personajes pertenecientes a las más bajas extracciones sociales, o populares, ciudadanas, como lo son los soldados y los criados de las comedias «a noticia» ya varias veces mencionadas. El autor es consciente de ello y lo expresa, entre líneas, en el Prohemio de Propalladia. 
Capítulo III 
$\underline{\text { Los aportes de Bajtín en torno a lo popular como viraje hacia una nueva }}$

$\underline{\text { concepción del teatro renacentista }}$

\section{Cultura cómica popular y teatro}

La fiesta es «el rasgo fundamental de todas las formas de ritos y espectáculos cómicos de la Edad Media» (Bajtín, [1965] 2003,14) y «los bufones y payasos» los personajes que la caracterizan (13).

En su A History of the Theatre $(1988,133)$ Glynne Wickham nos recuerda que no ha llegado hasta nuestros días ningún texto teatral escrito, ningún edificio teatral construido en Europa durante los cinco siglos que transcurren entre el saqueo de Roma -con Alarico en el 410 d.C-y la reforma de los monasterios benedictinos, momento que jalona el advenimiento del drama religioso cristiano a finales del s. X. Debido a este hueco histórico, aceptamos, entonces, el punto de vista ortodoxo de que los teatros fueron cerrados, los textos prohibidos, los actores relegados al rango de criminales (o en el mejor de los casos, de vagabundos) y este punto de vista permite pasar rápidamente al nacimiento del arte teatral en la baja Edad Media. Sin embargo, las pruebas que existen y que se pueden examinar sugieren que se trata de un punto de vista legendario y no real, cómodo pero no verdadero. ¿Por qué la necesidad de recordar este párrafo referido a tiempos tan lejanos? Bajtín a lo largo de su estudio analiza numerosas manifestaciones -sobre todo formas y rituales del espectáculo (festejos carnavalescos, obras cómicas representadas en las plazas públicas)- que confirman, no sólo la existencia de los mismos, sino también su continuidad en el tiempo, por lo menos en lo que se refiere al lenguaje del realismo grotesco. Por otra parte, estas manifestaciones son las mismas que denotan los rasgos 
evolutivos del arte teatral en la época. Como nos recuerda Wickham, estamos acostumbrados, por comodidad, a aceptar que el teatro, en la Edad Media en general, ha sido un acontecimiento silencioso. Bien sabemos que no es así. Más de una vez, en ámbito hispánico, reaparece la idea de que «la historia del teatro en lengua española durante la Edad Media es la historia de una ausencia» (Lázaro Carreter, 1976, 9). Y si nos limitamos estrictamente al texto, quizás esta afirmación sea verdadera; sin embargo, sabemos que muchas otras manifestaciones literarias o lúdicas (debates, recuestas, juegos cortesanos, momerías) son expresiones diversas del arte teatral. «Estrictamente contamos, antes del s. XV, con una sola obra dramática en lengua vernácula: el Auto de los Reyes Magos. Ante tan exiguo panorama caben dos posturas: el reconocimiento de la ausencia, que lleva aparejado el de la incapacidad de los castellanos medievales para el teatro, y la hipótesis de su existencia, que conlleva el esfuerzo por reconstruir lo que fue y se perdió, y a la que modestamente nos adherimos [...]» (Huerta Calvo, 1984, 11).

Con respecto a los siglos de la alta Edad media existe una contradicción entre la legislación oficial, que tiende a suprimir o poner orden en las manifestaciones teatrales, y la realidad que los documentos atestiguan, es decir, la existencia de actores, ludi scenici y spectacula provocatorios y peligrosos como lo habían sido en la época anterior (Wickham, 1988, 133). Según el mismo Wickham hay que explicar algunas paradojas que carcaterizan este período: por ejemplo, cómo es posible que la misma Iglesia cristiana de la época imperial, que había luchado para suprimir la actuación y cerrar los teatros, llegue, cinco siglos después, a asimilar el drama en las propias liturgias sacras. Asimismo, cómo es posible que la Iglesia en la alta Edad Media tolerara la existencia de rituales, claramente dramáticos como las mascaradas y los torneos, no obstante su proveniencia laica y que, más tarde, los utilizara con fines pedagógicos en los ciclos de los milagros. La respuesta se encuentra en la circularidad de los ritmos naturales relacionados a las temporadas en las comunidades de prevalencia agrícola. Las fiestas vinculadas a la fertilidad y a la cosecha mantuvieron siempre un rol fundamental. Se llevaban a cabo durante los solsticios de invierno y de verano y durante los equinoccios de primavera y otoño, 
como en la Antigüedad clásica. Es decir, no se interrumpió jamás la relación entre la ocasión y su celebración festiva (133-134). Una forma, inevitable, de compromiso o adaptación (como fue la «cristianización» del calendario) caracterizó la actitud de la Iglesia. Asistimos a un proceso lento de asimilación. Naturalmente, en los siglos, ha habido variantes y refundiciones, como lo demuestra Bajtín a través del análisis de las varias «fiestas de los bobos», del carnaval, de los torneos, de las momerías, de los dramas litúrgicos, de los milagros, de las procesiones del Corpus Domini (dramas de la Pasión), o respecto de los espectáculos realizados por los universitarios (juglares, prestidigitadores, acróbatas) etc.. Lo que es cierto es que un mismo hilo conductor une al arte teatral con la cultura cómica popular -así como la estudia Bajtín- y todo ello se extiende hasta la época que nos ocupa.

A partir de la teoría teatral moderna, que ha centrado la atención en los elementos «no verbales» del espectáculo, podemos afirmar que todas las actividades lúdicas desempeñadas por los juglares y bufones (Menéndez Pidal, [1942] 1991) o las varias fiestas «de bobos» o «del obispillo» pueden ser calificadas como teatrales. Como sucede en todos los países europeos, también en España se desarrollan ampliamente estas prácticas y muchos son los espectáculos parateatrales que se llevan a cabo durante las distintas festividades del año. Julio Caro Baroja, por ejemplo, en El carnaval (1979, 148-149), reproduce un cuadro en el que indica los distintos ludi theatrales o juegos de escarnio que se realizaban en los templos durante los días navideños (desde el 25 diciembre hasta el 6 de enero). Entre ellos incluye manifestaciones como la elección del «obispillo», la cuestación escolar, el paseo y la quema de muñecos, las elecciones de reyes, las libertades y bromas, las mascaradas de hombres disfrazados de mujeres, los animales, soldados, corridas de gallos, etc., festejos, en fin, que anunciaban el Carnaval con sus excesos y libertades.

Específicamente en el texto dramático renacentista vemos que existe una tradición temática y formal que echa sus raíces en el fondo medieval. El Códice de autos viejos junto con la producción teatral de Juan del Encina, Lucas Fernández, Torres Naharro (Gillet supo ver bien en Torres Naharro la escritura de varias 
generaciones del pasado), Gil Vicente, Sánchez de Badajoz ofrecen un material muy significativo para la reconstrucción del teatro medieval. Dicha reconstrucción, tomando como punto de referencia a los autores mencionados, «sería una operación similar -mutatis mutandis - a la realizada por Mijail Bajtín sobre la cultura popular del medioevo a partir de Rabelais» (Huerta Calvo, 1984, 13) ${ }^{36}$.

\section{El universo bajtiniano}

Ser, para Bajtín, significa comunicar dialógicamente y la existencia misma del hombre (sea la exterior sea la interior) es una profundísima comunicación ([1963] 1968, 331). A partir de esta idea de fondo se construye el pensamiento -una filosofía crítica y dialógica- del crítico ruso. Sin embargo, cabe aquí recordar un aspecto de no poco significado. Bajtín margina de su sistema teórico al género dramático por obedecer a una visión monológica del mundo. Una novela es -para el crítico- en mayor o menor medida, un sistema de diálogos, que comprende la representación de hablas, estilos, concepciones concretas, inseparables del lenguaje. El lenguaje de la novela no está solamente representado, sino que sirve a su alrededor de objeto de representación. La palabra novelesca es siempre autocrítica. En eso se distingue la novela de todos los géneros directos: poemas épicos, poesía lírica, drama en sentido estricto. Todos los medios directos de representación y expresión de estos géneros, y los géneros mismos, al introducirse en la novela, se convierten en objetos de representación ${ }^{37}$.

\footnotetext{
${ }^{36}$ Lo mismo «hizo Menéndez Pidal con las Crónicas medievales para reconstruir los fragmentos de la épica castellana perdida, pero ya no inexistente» (Ruiz Ramón, 2000, 31).

${ }^{37}$ «Un roman est, dans une plus ou moins grande mesure, un système de dialogues, comprenant la représentation des «parlers», des styles, des conceptions concrètes, inséparables du langage. Le langage du roman n'est pas seulement représenté, il sert à son tour d'objet de représentation. Le verbe romanesque est toujours autocritique. C'est en cela que le roman se différencie redicalement de tous les genres directs: poèmes épiques, poésie lyrique, drame au sens strict. Tous les moyens directs de représentation et d'expression de ces genres, et ces genres en eux-mêmes, en entrant dans le roman y deviennent objets de représentation. Dans le roman tel qu'il se présente, tout discours direct -épique, lyrique, dramatique- s'objective plus ou moins, devient même limité, et, fréquemment, comique, du fait même de cette limitation de sa représentation», (Bajtín, 1978, 409).
} 
Sin embargo, algunos críticos, en particular David Haymann, considera limitada la perspectiva de Bajtín y propone la ampliación del sistema al caso del teatro utilizando como ejemplos a Ben Jonson, Molière, Shakespeare, Goldoni, Marivaux, Jarry, creadores de un teatro cómico que «parecen perfeccionar y jugar con los elementos carnavalescos descritos por Bajtín» $(1980,86)$. La farsa y lo farsesco -elementos subyacentes a las producciones de esos autores- resultarían complementarios de la novela. Haymann, por otra parte, amplía el sistema carnavalesco de la literatura a ciertas obras contemporáneas no tenidas en cuenta por Bajtín; así Finnegans Wake, de J. Joyce; El tambor de hojalata, de Günter Grass, los Ubus de Jarry. Asimismo, como hemos ya mencionado, estudiosos del teatro renacentista español, se refieren al lenguaje carnavalesco para explicar la naturaleza, expresión y lenguaje de ciertos personajes, como es el caso de los rústicos.

La cultura popular en la Edad Media y en el Renacimiento es un trabajo que Bajtín desarrolla a lo largo de toda su vida. La substancial unidad de la obra, siguiendo la terminología bajtiniana, se caracteriza por el método de «especificación histórica», es decir, un método capaz de unir el orden de investigación diacrónico con el sincrónico. Esta monografía une, programáticamente, el análisis de la poética de Rabelais al amplio e históricamente estratificado fenómeno de la cultura popular. El crítico plantea, un doble recorrido: a través del estudio de la obra del autor francés comprende la evolución milenaria de la cultura cómica popular, pero, a su vez, ésta determina el sistema de imágenes de la obra del autor.

Bajtín afirma, siguiendo el pensamiento de Marx y Engels, que la clase hegemónica tiende a presentar sus ideas como «verdades eternas». Sin embargo, en la historia, la cultura cómica popular, que se expresa en el lenguaje de la fiesta y del carnaval, ha representado un fuerte elemento de oposición. En el Renacimiento el límite de demarcación entre lo oficial y lo no oficial adquiere un carácter móvil y la cultura cómica popular encuentra su máxima expresión en la concretización de formas literarias y artísticas consolidadas.

Bajtín plantea las bases teóricas de la discusión en torno a lo popular; sin embargo, su obra sobre la cultura cómica popular ha tenido escasísimo eco en 
España (Huerta Calvo, 1982, 149), tal vez, debido a la poca consideración del autor por la literatura española.

Nos permitimos -brevemente- sintetizar algunos de los conceptos fundamentales por él introducidos y que funcionarán como uno de los marcos metodológicos para la lectura de las «composiciones romanas» de Torres Naharro.

A partir de la premisa de que el «pueblo que ríe» no ha sido considerado por la crítica un objeto digno de investigaciones científicas profundas, Bajtín elabora su monografía. La risa adquiere un lugar primordial en la antropología filosófica del crítico ruso: ella no ata al hombre, al contrario, lo libera. Las puertas de la risa están abiertas para todos y para cada uno. «La verdadera risa auténtica, ambivalente y universal, no excluye lo serio, sino que lo purifica y lo completa. Lo purifica de dogmatismo, de unilateralidad, de esclerosis, de fanatismo y espíritu categórico, del miedo y la intimidación, del didactismo, de la ingenuidad y de las ilusiones, de la nefasta fijación a un único nivel, y del agotamiento. La risa impide a lo serio la fijación y su aislamiento con respecto a la integridad ambivalente» $(2003,112)$.

Esta visión amplia de la risa es la base de la concepción estética denominada, convencionalmente, realismo grotesco. El uso que hace Rabelais de lo popular en la escritura letrada significó una transgresión de los cánones literarios de la época. El autor francés usa de manera consciente las posibilidades «transgresivas» de lo popular para cuestionar las jerarquías literarias vigentes. La cultura popular es cómico popular y tiene como lugar privilegiado de expresión el carnaval. El mundo carnavalesco se desarrolla en el ámbito de la fiesta, en la plaza pública y su lógica es la inversión de los valores en cuanto oposición al dogmatismo y seriedad de la cultura oficial. Un fluir destructor y regenerador (muerte, resurrección, sucesión de los ciclos vitales) constituyen los aspectos esenciales de la fiesta del carnaval. A la oposición conceptual de cultura oficial/cultura popular corresponde la oposición canon clásico/canon realístico grotesco. La oposición entre estas dos concepciones estéticas, sin embargo, no deben ser absolutizadas. A nivel histórico las mezclas, o circularidades han sido fuertes. Para explicar aquello que diferencia a estos dos cánones, Bajtín se refiere a la distinta representación del cuerpo humano. Los 
cánones clásico y moderno-burgués presentan una imagen del cuerpo perfecta, un cuerpo formado, rigurosamente delimitado, clausurado, mostrado del externo, homogéneo y expresivo de una individualidad cerrada; la imagen grotesca, en cambio, muestra cada fenómeno y, por lo tanto, también el cuerpo humano, en su momento de cambio. De aquí que en la concepción estética del realismo grotesco domina, como sabemos, el principio material y corporal: imágenes del cuerpo, del comer y del beber, de las necesidades naturales, de la vida sexual. Las imágenes del principio material y corporal son una herencia (que naturalmente ha tenido sus transformaciones a través de los siglos, desde el folklore primitivo a través de la civilización post-clásica, helenística y romana -la sátira menipea ocupa un lugar primordial- hasta llegar a su afirmación con el Cristianismo y el comienzo de la Edad Media, y alcanzando su ápice artístico en la literatura renacentista) de la cultura cómica popular y de aquel tipo particular de imagerie que se distancia de las concepciones estéticas de los siglos posteriores. Se trata de imágenes hiperbolizadas, exageradas, que asumen un carácter positivo-afirmativo y que remiten a la fertilidad, al nacimiento, al crecimiento en abundancia. El lenguaje del realismo grotesco tiene un carácter cósmico y, por ello, universal, porque no habla de un ser biológico aislado, de un individuo burgués egoísta, sino de pueblo en su totalidad; es un cuerpo popular, colectivo. Lo cómico, lo social y lo corporal forman una unidad indisoluble, un todo orgánico e indivisible. Las imágenes se presentan en su aspecto universal, utópico y festivo. La abundancia y la universalidad determinan el carácter festivo de la vida material y corporal y, por lo tanto, el espacio en el que se genera es la fiesta, el banquete, donde domina el principio de la alegría.

Característica fundamental del realismo grotesco es la degradación (sniženje): bajar todo lo que es alto, espiritual, ideal, abstracto, al plano material y corporal, al plano de la tierra y del cuerpo. La risa popular que organiza todas las formas del realismo grotesco se encuentra en estrecha relación con lo bajo (niz) material y corporal. La risa baja y materializa. Lo bajo y lo alto asumen para Bajtín un carácter topográfico: cielo (alto)-tierra (bajo); la tierra es el principio de absorción (la tumba, el vientre) y al mismo tiempo de nacimiento y resurrección (el seno 
materno), esto en sentido cósmico. En el sentido estrictamente corporal: la cabeza (alto)-los órganos genitales, el vientre, el trasero (bajo). La degradación significa acercamiento a la tierra, como principio que absorbe y que al mismo tiempo da vida; bajando se entierra y al mismo tiempo se siembra, se muere para volver a nacer. Por ello, no tiene un valor sólo destructivo, negativo, sino también positivo y regenador: es ambivalente, niega y afirma al mismo tiempo.

La idea central del texto es que Rabelais adquiere una dimensión nueva de lugar y de tiempo históricos que se encuentran en estrecha relación con el devenir del hombre y del mundo. La cultura popular, en la nueva concepción, es el núcleo del discurso. Las imágenes literarias de Rabelais tienen su origen en la evolución milenaria de la cultura popular y las fuentes populares determinan el sistema de imágenes de su obra y su concepción artística.

3. Algunos elementos que constituyen el lenguaje del realismo grotesco y que aparecen en las piezas de Torres Naharro.

En las comedias de Torres Naharro aparecen, a menudo, aquellos elementos que constituyen el lenguaje del realismo grotesco: el vocabulario de la plaza pública, las formas y las imágenes de la fiesta popular, las imágenes del banquete -tan importantes con relación al teatro- la imagen grotesca del cuerpo, lo «bajo» material y corporal.

En el II capítulo del estudio sobre La cultura popular en la Edad Media y en el Renacimiento el crítico ruso especifica -a través del análisis de los prólogos de Garganúa y Pantagruel y de los géneros verbales de la plaza- el vocabulario de la plaza pública e individualiza los elementos que la caracterizan. Se trata -como él mismo escribe- de aquellos elementos que, a partir del siglo XVIII, fueron «el 
obstáculo principal de sus admiradores y lectores» $(2003,131)^{38}$ y que, incluso en la actualidad, obstaculizan una puesta en escena de la obra de Rabelais: uno de los escritores que mejor se adaptaría a una representación teatral. Esta afinidad que muestra la obra literaria (en este caso de Rabelais) con el teatro y con la plaza pública -su representabilidad - remite a la unidad de fondo entre la cultura cómica popular y el teatro, en otras palabras, a los espacios contiguos.

Por otra parte, subraya que hasta el presente el vocabulario de la plaza pública deja perplejos a los lectores de Rabelais que «no logran integrar esos elementos orgánica y totalmente en la trama literaria» (Ibid). Y algo similar sucede con los lectores/críticos del teatro renacentista.

Los prólogos - «magníficos ejemplos de la obra publicista del Renacimiento inspirada en la plaza popular durante la fiesta» $(2003,175)-$ son, pues, los que presentan la atmósfera verbal característica de la plaza. No todos los elementos que enumera el crítico ruso están presentes de manera marcada en la obra de Torres Naharro, sin embargo muchos de ellos se reproducen -atenuados, a veces- en los introitos y a lo largo de sus comedias. Nos detenemos en aquellos que adquieren mayor significado para la obra de nuestro autor: los elogios, la celebración del «estimado público», las injurias, el «grito»o «pregón» de la plaza pública, las imágenes del banquete.

\subsection{Elogios}

El introito de la comedia Tinellaria comienza del siguiente modo: «Hasta aquí por excellentia / me sirvió la suerte mía, /que me conduxo en presentia / de tan alta compañía. / Ciertamente, / servir a tan noble gente / no ha sido mal pensamiento, / si el servicio es conveniente / con tanto merescimiento». El elogio de los presentes, del público, es uno de los componentes que más caracteriza las obras renacentistas.

\footnotetext{
${ }^{38}$ Bajtín cita los comentarios de La Bruyère que calificaba dichos elementos como «delicias de la canalla» y «sucia corrupción». Voltaire, por otra parte, los definía «revoltijo de impertinentes y groseras porquerías».
} 
En particular, los dramaturgos utilizan a sus personajes para alabar al señor y a su vez pedir subsidios. Por citar un ejemplo, en la égloga De las grandes lluvias (núm 9) de Juan del Encina, detrás de la comicidad villana, se esconde el autor para disputarle a su rival, Lucas Fernández, los favores del mecenas por un puesto en la capilla. Lo que caracteriza los prólogos (de Rabelais) es «el estilo de los charlatanes de feria y vendedores de libros de cuatro centavos, que no cesan de prodigar elogios a los remedios milagrosos y libros que ofrecen, a la vez que elogian al "muy estimado público"» $(2003,144)$. Se trata de un ejemplo típico del tono y del estilo de las peroratas de los charlatanes impregnadas de la risa festiva popular. Este lenguaje contribuye «a crear la atmósfera típica de la plaza pública a través de su juego libre y alegre, en el cual tanto lo superior como lo inferior, lo sagrado y lo profano, van adquiriendo derechos iguales y son incorporados unánimamente a la ronda verbal».

En el provocatorio introito de la comedia Soldadesca asistimos a un juego libre entre lo superior/inferior, sagrado/profano planteados a partir de los «iguales derechos». El villano pone sobre un mismo plano, no sólo a los espectadores, sino también al mismo Papa. Se dirige al público tratándolo como ignorante y lo considera como posible estafador. Ironiza sobre las dificultades de quien ocupa los espacios espirituales y de poder. El objetivo directo de sus ataques es el Papa. Contrapone los aspectos positivos de su vida a los del Padre espiritual: el rústico duerme mejor en su lecho de paja que el Papa, come con más ganas, bebe el agua del río y fundamentalmente vive "como cristiano" trabajando con sus manos.

La figura del pastor rústico del introito narrahesco ha sido motivo de estudio en varias ocasiones a partir de la perspectiva bajtiniana. Hermenegildo escribe que «los rasgos que determinan la estructura profunda del loco de la fiesta popular, del carnaval, tal como han sido estudiados por Mihaíl Bajtín [...], surgen de modo recurrente en el teatro español a lo largo de los siglos XVI y XVII. En otras palabras, la figura carnavalesca se encarna de maneras multiformes en la práctica cultural que llamamos teatro clásico español» (Hermenegildo, 1995, 10).

Bajtín destaca que en todos los elogios domina el superlativo y subraya que no se trata de un superlativo retórico sino que «es un superlativo resuelto, exagerado 
y un poco alevoso; es el superlativo del realismo grotesco. Es el rostro al revés (o al derecho) de las groserías» (145). No se trata de términos «objetivos», «neutros»: o son elogiosos, como los «tan alta compañía» «tan noble gente» «ante tanta magestad» de Tinellaria, o definidamente groseros como el «rebentado muera yo» y «la puta que me parió» en la boca del rústico del introito de la comedia Jacinta.

\subsection{Injurias y parodias}

Otro aspecto que destaca Bajtín es el pasar de los elogios a las injurias, es decir, la otra cara de los elogios callejeros. Expresiones como «desgraciado», «cobarde», «saco de maldad», «grossero», «hideputa», «poltrón», «asnejón», «majadero», «ahorcados», «cabrón», «fi de caun» (dicho por el portugués, v. 683), «forfante», aparecen en la comedia Tinellaria, más todas aquellas variantes en lengua italiana, como «sassin», «coglione», «mincione», «poltrone», «gagliofo», «marranazo» que se agregan en la comedia Soldadesca.

Bajtín con respecto al prólogo de Pantagruel escribe que «de principio a fin se trata de una parodia de la Iglesia salvadora, la única autorizada para poseer e interpretar la palabra divina» ${ }^{39}$. Una parodia riesgosa, hecha con estilo cómico, bajo forma de risa y de alegres peroratas de plaza que garantiza la impunidad del autor. «El charlatán de feria nunca era acusado de herejía por sus afirmaciones, a condición de que se expresara en forma bufonesca» (148). Los personajes del tinello narrahesco utilizan todos este estilo bufonesco para hablar de la venta de beneficios y de la

\footnotetext{
${ }^{39}$ Bajtín comenta del siguiente modo el comienzo del prólogo de Pantagruel y el elogio de la Crónica de Gargatúa: «los que no están de acuerdo con el autor de las Crónicas son tratados de «abusones», «impostores», «predestinadores», «seductores» calificativos que eran aplicados a quienes se acusaba de herejía y eran enviados a la hoguera. El autor sigue jugando con las cosas serias y peligrosas, y compara a propósito las Crónicas con la Biblia y los Evangelios; pero se pone paradójicamente de parte de la Iglesia, acusando de herejía a quienes no comparten su opinión sobre las Crónicas, con todo lo que esto implica. [...] El elogio ditirámbico de las Crónicas, el mejor y único libro del mundo, y de sus devotos lectores, dispuestos a sacrificar su vida en defensa de la virtud salvadora de la Crónicas, (bajo la forma irónica y ambivalente del «cuartillo de tripas»), y deseosos de sostener esta convicción «excepto» ante la hoguera, y por último la acusación de herejía lanzada a los opositores es, de principio a fin, una parodia de la Iglesia salvadora, la única autorizada para poseer e interpretar la palabra divina (El Evangelio)» (148).
} 
corrupción de la iglesia. «G: Vistes tal? / Veis qu'es regla general / que todos piensan so capa: / 'l obispo ser cardenal / y el cardenal de ser papa. / O: ¿Cómo no? / Pues también me pienso yo / ser obispo de mi tierra. / G: Pensando ganar, murió / mi padre, yendo a la guerra» (vv. 1077-1081). Estos versos se refieren a la escena en que el personaje de Osorio está solicitando un beneficio. Un astrólogo judío ha dicho, por muy cierto, que el cardenal del Bacano será Papa y si el escudero lo seguirá podrá tener un confesionario. Se trata de una reflexión de Naharro en boca de los escuderos; es regla general que todos piensen en sí mismos y en el ascenso de rango: el obispo quiere ser cardenal y el cardenal Papa. Al fin, Osorio dice que él también piensa ser obispo de su tierra. Naharro, autor, hace una reflexión: «pues qu'el pensar no es saber / ni el soñar es prophetía, / demandemos de comer, / qu'es otra mercadería» (vv. 1088-1091). Recordemos que Gillet, atribuye a mercadería, no sólo el significado de cosas vendibles, sino también el de asunto, trato, comercio de favores. Los títulos y los beneficios se compran y se venden como la comida. La sátira de Naharro en este fragmento de la comedia es múltiple: no se dirige sólo al escudero sino a los valores pervertidos que dominan los altos niveles de la jerarquía eclesiástica. Se habla de un Cardenal del Bacano. El Bacano era un lugar de los suburbios de Roma donde, a menudo, se cometían crímenes, y la alusión al Bacano puede ser vista también como la del dios del vino. El cardenal del Bacano aspira al pontificado, es por lo tanto el posible futuro Padre espiritual de los cristianos, y como valor antitético consulta a un astrólogo judío, con todo lo que ello implica en aquella época. Crea, además, cierta comicidad el hecho de que el Papa futuro ponga su confianza sólo en los astros. Los escuderos hacen referencia a León X, que en este momento es Papa desde hace poco (1513), que está presenciando además la representación de la comedia y refiere el hecho de que vivirá mucho, por lo tanto a poco puede aspirar el Cardenal del Bacano.

La misma licencia se toma el rústico de la comedia Soldadesca, antes mencionado, con las burlas directas dirigidas al Papa.

Los elogios y las injurias son las dos caras de una misma moneda y la palabra de la plaza un Jano bifronte. El Cardenal de la comedia Tinellaria, no casualmente, 
es el Cardenal de San Jano, llamado vulgarmente el Cardenal del Bacano; esta referencia a la divinidad latina alude a la doble actitud moral del Cardenal.

Con respecto a la fusión de los elogios y las injurias en una misma imagen, Bajtín subraya que se trata de un fenómeno de extrema importancia que ha sido poco estudiado y que permite comprender las grandes etapas del desarrollo del pensamiento humano del pasado. «[...] en su base reside la idea de un mundo en estado de permanente imperfección, que muere y nace al mismo tiempo, es decir un mundo bi-corporal. La imagen dual que reúne a la vez elogios e injurias, trata de captar el instante preciso en que se produce el cambio, la transición de lo antiguo a lo nuevo, y de la muerte al nacimiento. Es una imagen que corona y derroca al mismo tiempo» $(150)$.

Otro aspecto que se encuentra en Rabelais y que reconocemos también en Naharro es que acostumbra a terminar los prólogos o con groserías o con invitaciones a banquetes y a beber. La invitación a beber en el lenguaje de las imágenes de la plaza pública significa comunicar con la verdad. La disposición de grandes comilonas y borracheras cierran y abren las jornadas de la comedia Tinellaria, hasta alcanzar el ápice, en la jornada quinta, cuando la gula, glotonería, voracidad, bestialidad -elementos bajtinianos, seguramente- llevan a los personajes a organizar y asistir a un gran bacanal que acaba con la representación de un naufragio en la oscuridad y vómitos. Las palabras alegres, los insultos afectuosos, las groserías obscenas y el banquete son los que ejemplifican algunos rasgos fundamentales del realismo grotesco. «Se trata en realidad de la expresión más simplificada de lo «inferior» material y corporal ambivalente: risa, alimento, virilidad y elogios-injurias» (154). Y mucho de todo ello se encuentra en las comedias de Naharro cargadas de imágenes de banquetes, de elementos de la comicidad popular, de juegos de palabras, de sobreentendidos e inversiones verbales. 


\subsection{El grito}

El tono y el estilo de los prólogos de Rabelais se inspiran en los géneros publicitarios y en el lenguaje familiar callejero $(151)^{40}$. La palabra en el prólogo es el «grito» o «pregón» y la lengua utilizada -en nuestro caso no sólo de los prólogos- es la lengua hablada. La construcción que hace Rabelais es como una conversación familiar del vendedor ambulante con el público alrededor. Es la misma técnica que utilizan los juglares. Podemos hacer un paralelo con el discurso introductivo hecho por los actores ambulantes antes de la representación. La forma en que se dirige el «juglar» busca siempre el tono familiar y popular con los lectores/auditores, como es el caso de los pastores rústicos de los introitos narrahescos, «ya que se trata de una forma típicamente hablada» (152).

Los gritos (los gritos de París) son importantes, no sólo para la historia de la civilización y de la lengua, sino también para la historia de la literatura, escribe Bajtín. Estos gritos o pregones eran muy importantes en la vida de la plaza y los temas que abarcaban eran de lo más variados: alimentos, bebidas o ropas. Poseían un vocabulario propio, una melodía y entonación, es decir, como nos señala Bajtín, tenían su propia figura verbal y musical. El estudioso ruso recuerda que no sólo la propaganda era verbal y proclamada en voz alta, gritando, sino también las ordenanzas, anuncios, bandos, leyes. Es decir, el papel del sonido y de la palabra hablada ocupaban un lugar importante, circunstancia de la que no se puede prescindir cuando se estudia el estilo del s. XVI. Y en las comedias «a noticia» tenemos la sensación de que Naharro ha puesto un grabador para luego reproducir la lengua hablada de los tinelleros y soldados. El realismo que caracteriza sus páginas corresponde a esta idea planteada por Bajtín. El ejemplo más evidente es la escena de la segunda jornada de Tinellaria en la que los personajes se expresan en varias lenguas. Cada uno de ellos exalta las maravillas de su país. La gran armada española, Lisbona gran ciudad, el burdel de Valencia, la universidad de París. Burlas típicas de

\footnotetext{
${ }^{40}$ Con respecto al prólogo de Pantagruel escribe: «Se escuchan los gritos del charlatán de feria, del vendedor de drogas milagrosas, del vendedor de libros de cuatro centavos, y los insultos groseros que siguen anuncios irónicos y elogios de doble sentido» (150).
} 
las virtudes y defectos de cada nación: los castellanos tienen cola, Cristo fue portugués mientras que Judas viene de Córdoba. Se acusa a los españoles de orgullo y arrogancia. Se excitan recíprocamente, en una suerte de burdo nacionalismo. La cultura de la lengua era, pues, en gran medida la de la palabra proclamada a viva voz, al aire libre, en la plaza y en la calle (163).

Bajtín recuerda también la importancia que tenían en el lenguaje de la plaza pública las enumeraciones de distintas mercaderías, objetos domésticos, ropas, utensilios de cocina, armas. En la comedia Tinellaria las varias comilonas que llevan a cabo los tinelleros, escuderos y siervos están siempre bien específicadas o por su abundancia o por su escasez. «E: Haz de modo / que nos pongas oy del lodo / con tu afán y / nuestro gasto. / B: Mira qu'el hígado todo / lo apartes del antepasto. / Y pues, cata: / haz una salsa beata / que nos sea reservada, / y el grasso de la piñata / pássalo en nuestra caolada» (vv. 448-457). Explicaciones como ésta aparecen a menudo. «B: Anoche henchí los senos, / sin que asimos yo y un paje / siete pasteles muy buenos / de ciervo y puerco salvaje» (vv. 509-512). Este universo de objetos y comida adquiere un significado importante en la literatura del s. XVI. Mencionar y describir todo lo que tuviera relación con la cocina y el comer formaba parte del gusto de la época. Los gritos eran una cocina sonora, un banquete sonoro en el que cada producto y cada comida tenía su propio ritmo y propia melodía; como escribe Bajtín, se trataba de una sinfonía de la cocina y del banquete que resonaba por las calles. Y en este sentido, la comedia Tinellaria representa la hipérbole de los banquetes. En la literatura del s. XVI, las escena de banquetes y cocina no eran detalles limitados al círculo estrecho de la vida cotidiana. Estas escenas tenían una significación universal en mayor o menor proporción, la de satirizar y adquirir significados más amplios. Bajtín menciona (165) unas sátiras protestantes de la segunda mitad del s. XVI, Sátiras cristianas de la cocina papal, en la que la Iglesia católica es descripta como una cocina gigantesca, en la cual se la degrada transfiriendo todo su ritual al plano «inferior» material y corporal. Los pregones 
estaban directamente relacionados con «las formas más importantes del pensamiento metafórico de la época» ${ }^{41}$.

\subsection{Juramentos}

Los juramentos -«vivencias antiguas de fórmulas sagradas» (170)-, las groserías y obscenidades son los elementos extraoficiales del lenguaje considerados siempre como una violación de las reglas y de las convenciones verbales: etiqueta, cortesía, piedad, consideración, respeto de rango (169). Se juraba por Dios, por su cuerpo, por su sangre, por los santos, sus reliquias etc. En las comedias de Naharro aparecen constantemente los juramentos a Dios y a su cuerpo: ¡al corpo de Jesuchristo! ipel cul de Deu!, ¡voto ao corpo de Deus!. En el introito encontramos los siguientes versos: «¡Jur’a Dio! ¡Voto a Dios! / ¡Per mon arma! ¡Bay fedea! / ¡Io, bi Got! y ¡Cul y cos! / ¡Boa fe, naun, canada e mea!». Bajtín cita, como ejemplo, los ventiún juramentos que aparecen en un fragmento de Rabelais expresados en distintas lenguas, no muy diferente de estos versos citados de Naharro en el que aparece el reflejo de las expresiones de la multitud ruidosa y multilingüística por la calle; se trata de un retrato sonoro, que en la obra de Naharro aparece constantemente.

El tema de los juramentos era variado. El más importante indicado por Bajtín es el despedazamiento del cuerpo humano. Se jura por el cuerpo de Dios, por su cabeza, su sangre. Los juramentos más reprochables eran, sobre todo, los que se referían al cuerpo de Dios y a sus partes y, sin embargo eran los más difundidos. Por

\footnotetext{
${ }^{41}$ «Los 'pregones de París' constituyen un aspecto importante de la plaza pública y de la calles y se ensambla en la utopía de la fiesta popular que allí reina. Rabelais percibía en la fiesta popular los tonos utópicos del 'banquete universal', ocultos en el centro mismo de la vida ruinosa, viva, concreta, perceptible, de mil olores y llena de sentido práctico de la plaza pública, lo cual correspondía plenamente al carácter específico de las imágenes de Rabelais, que combinan el universalismo y la utopía más amplia con un carácter concreto, visual, vivente, con una rigorosa ubicación espacial y precisión técnica».
} 
otra parte los juramentos, con sus despedazamientos remiten al tema de la cocina, el cuerpo despedazado=picadillo (174).

\section{Las imágenes del banquete}

Como hemos dicho, en la literatura del s. XVI, las escenas de banquetes y cocina no eran detalles limitados al círculo estrecho de la vida cotidiana. Estas escenas abarcaban significados que iban más allá de lo estrictamente culinario. El fondo satírico era una de sus mayores características. La comedia Tinellaria no sólo fue representada durante un banquete frente al Papa de los Medici, León X, como lo testimonia la dedicatoria al cardenal Bernardino Carvajal publicada en la edición suelta de la comedia, ${ }^{42}$ sino que, también, su misma acción dramática representa una continua preparación de banquetes. La primera jornada se abre con la preparación de un banquete para el cardenal de San Jano, alias cardenal del Bacano y así, a continuación, las siguientes jornadas transcurren, en su mayoría, alrededor de la mesa. En esta comedia todo gira en torno a la comida. Bajtín escribe sobre las imágenes del banquete que «se asocian orgánicamente a todas las otras imágenes de la fiesta popular. El banquete es una parte necesaria en todo regocijo popular» (2003, 250-251). El banquete, por otra parte, como veremos, desempeña un papel central en la poética espectacular del s. XVI.

Las imágenes de los convites, - del comer y del beber-, tienen una relación secular con la palabra. Y Bajtín especifica que las mismas imágenes del banquete «liberan la palabra». Por otra parte, estas imágenes tienen una fuerte tendencia a la abundancia y a la universalidad, que determinan la formulización misma de tales imágenes, «su hiperbolismo positivo, su tono triunfal y alegre» (250). Muchas de las

\footnotetext{
${ }^{42}$ Dice el texto: «Acuérdome que después de recitada esta Comedia Tinelaria ala San[tidad] D[e] N[uestro] S[señor] e a monseñor Reveren[dísimo] de Médicis patrón mío, V[uestra] S[eñoría] Revere [ndísima] quiso uerla y después de uista me mandó que en todo caso le diesse la copia della. Tras desto me demandó la causa por qué no dexaua estampar lo que escreuía»-Aliprandini de, L. (1985) reproduce la edición de la suelta de la comedia Tinellaria de fecha incierta, aunque anterior a la versión napolitana de 1517.
} 
características del banquete se encuentran en la obra de Naharro y, en algunos casos, adquieren el mismo significado. Los personajes del naufragio narrahesco de la última jornada beben, comen, cantan y bailan compulsivamente. Algunos están en el piso, otros hacen movimientos de natación, tratan de alzarse para juntarse con los otros. El naufragio y la oscuridad, aquí, nos remiten a aquel sistema de imágenes que, como dice Bajtín lleva a «una nueva compresión de la verdad», in vino veritas, «el vino libera de la piedad y del temor. «La verdad en el vino» es una verdad libre y $\sin$ temor» (257) que permite un encuentro triunfal y alegre con el mundo (el hombre traga al mundo sin ser tragado por él).

Otro aspecto interesante es que no puede existir un «comer triste», la tristeza y el comer son incompatibles. El banquete celebra siempre la victoria y, como triunfo y renovación, a menudo ocupa en el arte popular las funciones de conclusión (254). Así sucede en el banquete/orgía final de la comedia Tinellaria.

Existe una relación clara, puesta en evidencia por Bajtín, entre el banquete y la sátira cuando recuerda el uso de las imágenes cómico-grotescas en el Tratado de García de Toledo. Las imágenes del banquete, también ambivalentes, en este texto son puestas al servicio de una tendencia estrictamente satírica -como, según nuestra opinión, hace Torres Naharro en sus comedias- y, por lo tanto, negativa; sin embargo, las mismas conservan su naturaleza positiva. «Es esta última la que engendra las exageraciones, aún cuando sean empleadas con fin satírico» (261-262). La negación no toca la materia misma de las imágenes, es decir, el vino, la comida, la abundancia. Esta materia permanece positiva. Las imágenes con fin satírico continúan viviendo su propria vida en el convite. No se agotan en la tendencia a la cual sirven. «Esto tampoco perjudica la sátira: el autor denuncia a la curia de una manera muy eficaz; al mismo tiempo, experimenta la influencia de la fuerza positiva de sus imágenes del banquete, que crean un ambiente de libertad permitiéndole parodiar -en el caso del Tratado de García de Toledo- los textos litúrgicos y evangélicos» (262).

Los personajes de Tinellaria, como asimismo de Soldadesca, encierran características extremamente negativas: glotonería, envidia, lujuria, mentira; sin 
embargo, las imágenes que utiliza el autor para mostrar los vicios y bajezas de los tinelleros y soldados conservan la misma fuerza positiva (y subversiva) de la que habla Bajtín. Las comedias en cuestión tienen una fuerte carga satírica a través de las que se denuncia la corrupción eclesiástica, las formas externas en la práctica religiosa $\mathrm{y}$, en el caso de Soldadesca, la conducta dudosa de los ejércitos mercenarios.

La tercera jornada de la comedia Tinellaria se abre y cierra con dos bendiciones/maldiciones: están entrando los personajes a comer y entre ellos no hay ningún capellán para rezar la bendición. Godoy hace la bendición que precipitadamente se convierte en maldición. Bendice al Cardenal que les da de comer, el pan el vino y toda la comida. Maldice a los criados traidores: al Cuoco que hace la menestra flaca, al Despensero que compra mula por vaca, al Canavario que les da vino ruin y al Escalco que les sangra el ordinario. El juego libre con las cosas sagradas es una constante que caracteriza la época medieval. Según Bajtín, la parodia sagrada ocupa un lugar importante en la unidad de la cultura cómica popular. «La parodia medieval (sobre todo la clásica ed decir hasta el s. XII) no se propone sólo describir los aspectos negativos o imperfectos del culto, de la organización eclesiástica y la ciencia escolar. Para los parodistas, todo, sin excepción, es cómico; la risa es tan universal como la seriedad, y abarca la totalidad del universo, la historia, la sociedad y la concepción del mundo » (80) y a partir del s. XI el arte paródico comienza a incluir en el juego cómico todos los elementos de la doctrina y del culto oficial en general. La tendencia es ridiculizar y degradar.

La parodia grotesca más antigua que recuerda Bajtín es la Coena Cypriani (entre el s. V-VII) que utiliza la historia sacra desde Adán hasta Cristo como material para representar un banquete excéntrico y bufonesco utilizando con fines grotescos los hechos más importantes y los símbolos de esta historia.

La jerga de los monjes, de los clérigos, de los escolares, de los jueces y en general el habla popular estaban contaminados de parodias de distintos textos religiosos, de plegarias, sentencias, proverbios comunes y, en fin, de nombres de santos y de mártires. La tradición medieval del banquete se desarrolla en dos 
direcciones más: las misas paródicas de los borrachos y la lírica en latín de los clérigos vagantes. En la mayoría de los casos seguían estrictamente los textos de las verdaderas misas religiosas, parodiándolas. Recuerda Bajtín que, en este último caso, las imágenes del vino y de la borrachera no tienen valor ambivalente. Este tipo de parodia se acerca más, por su carácter, a una parodia superficial y formal de la Edad Moderna, aunque subraya que, desde la Coena Cypriani, hasta las homilías de Zeno, las sátiras y las parodias más recientes de los siglos XV y XVI, las imágenes del banquete «liberan la palabra» (266). El contenido esencial de estos textos es el «juego libre con las cosas sagradas» (266).

La bendición conclusiva de la tercera jornada se concentra sobre los placeres de la vida: «bendigamos / al buen tiempo que nos damos / en torno a Campo de Flor / y a lo poco que pensamos / en servir a Monseñor» (vv. 1586 -1590); «bendigo al Sancto Natal, / que dan la torta tan ancha, / maldigo al ruin oficial / porque demanda la mancha» (vv. 1592 - 1595) «Buena gente, / aquel Dios omnipotente / nos haga sus herederos, / y nos dé continamente / salud y paz y dineros» (1611- 1615). Ocio, buen comer, dinero son los mayores intereses que poseen estos personajes. Estos versos finales son un juego alternado entre bendición / maldición, que recuerda el aspecto, más veces subrayado por Bajtín, sobre la ambivalencia en las imágenes de la cultura cómica popular.

Hemos enumerado algunos de los elementos del realismo grotesco que resultan evidentes también en la obra de nuestro autor. En el capítulo siguiente analizaremos específicamente cada uno de ellos colocándolo en los marcos más amplios, no sólo de la filosofía bajtiniana, sino también de la poética de Torres Naharro y de la poética espectacular de comienzos del s. XVI. 


\section{Capítulo IV}




\section{$\underline{\text { Naharro dramaturgo - Naharro satírico }}$}

\section{Una biografia controvertida}

Visu affabili, persona grandi, gracili et modesto corpore, incessu graviori, verbis parcus, et non nis premeditata et que statera ponderata habentur, verba emittit.

Torres Naharro es un hombre a mitad entre genio e ingenio, con más agudeza que fantasía; espíritu penetrante y observador, creatividad picante y mordaz, gran libertad de ánimo, desenfado de expresión y sentido moral recto (M. Pelayo, 1941, 305). A lo largo de su vida, al afirmar que «toda mi vida serviendo y pobre ansí como ansí», se considera un «medio escolar», alguien cuya personalidad se alterna entre luz y sombra. Además, es un amante frustrado, un hombre inteligente, un idealista sentimental dividido entre la ternura de su proprio corazón y la amargura de su mente lógica (Gillet, 1961, 401-417).

En el primer capítulo de Propalladia escribe: «Por tales senderos me guía mi suerte, /que sé donde voy y yerro la vía; / la vida es conmigo, yo siento la muerte; tristeza me sobra, publico alegría» ${ }^{43}(1994,30$, vv 1-4). Esta "tristeza me sobra, publico alegría» es la que ejemplifica muchas de las facetas de la vida y de la obra de Naharro. Debajo del velo de la «tristeza» poética es la «alegría publicada» la que ofrece una imagen grotesca de las bajezas papales de la corte romana y de su corrupción moral: venta de beneficios, costumbres relajadas que se mezclan con un

\footnotetext{
${ }^{43}$ Torres Naharro, ed. M.A Pérez Priego, 1994. Todas las citas referidas a Propalladia de B. de Torres Naharro están tomadas de la presente edición.
} 
hedonismo exasperado. Una Roma ilustre que emana cultura por sus poros pero que, a su vez, representa la cuna de la inmoralidad.

Los únicos datos que conocemos sobre la vida del autor se encuentran en las dos cartas latinas que encabezan Propalladia: la carta de Mesinierus I. Barberius Aurelianensis a Jodocus Badius Ascensius, famoso humanista e impresor parisiense de origen belga, y el privilegio concedido por el Papa León X para la publicación de la obra.

Mesinierus nos informa que el autor nace en el pueblo extremeño Torre de Miguel Sesmero ${ }^{44}$, provincia de Badajoz, en la familia Naharro ${ }^{45}$, que posee una amplia cultura literaria y que conoce las lenguas clásicas, tanto que, refiere, habría podido escribir toda su obra en latín. Algunos críticos, a partir de esta afirmación, suponen que Naharro haya estudiado en la universidad de Salamanca ${ }^{46}$ : un grupo de jóvenes estudiantes entre los cuales se encontrarían Naharro, Gil Vicente, Lucas Fernández y Sánchez de Badajoz habrían sido guiados por Juan del Encina en la actuación de las representaciones de las églogas de este último en el Palacio del duque de Alba (Lihani, 1979, 16).

Naharro inicia, probablemente, la carrera eclesiástica en su diócesis natal ${ }^{47}$. Sin embargo, la comedia Soldadesca revela, según algunos críticos, que el autor tiene conocimientos del arte militar. Así es, que Menéndez Pelayo lo ve en los ejércitos cristianos luchando en la frontera de Granada (1941, 274), mientras Zimic piensa que hasta habría abandonado los hábitos para emprender la vida militar, es más, interpreta este abandono como una reacción en contra de la corrupción de la Iglesia. Mesinierus en la carta escribe que infieles lo capturan ${ }^{48}$ en la travesía, antes

\footnotetext{
44 «Natione Hispanus, patria Pacensis; ex opido de la Torre, gente Naharro», escribe Masinierus en la carta. Consultar Menéndez Pelayo (1941, 272); López Prudencio, (1934, 162).

${ }^{45} \mathrm{La}$ fecha de nacimiento permanece aún incierta. Mazzei $(1922,54)$ la coloca entre 1470-1480, Gillet $(1961,402)$ alrededor de 1485.

${ }^{46}$ Menéndez Pelayo $(1941,272)$ Gillet $(1961,402)$ y Lihani $(1976,16)$.

${ }^{47}$ El Papa en el privilegio lo llama «dilectus filius» y «Clericus Pacensis diocesis». En qué momento de su vida, Naharro toma los hábitos es un enigma. Algunos lo ven ordenado sacerdote en su tierra natal (Gillet, 1961, IV, 402-403), otros más tarde en Roma (McPheeters, 1973, 13).

${ }^{48}$ Moratín lo ve hasta cautivo en los baños de Argel. El texto de Mesinierus dice: «Cuius fortuna a principio satis dificilis, quoniam naufragio ab Agarenis pro mancipio captus est; habitaque illius postea pecuniaria cautione, Romam devenit (...)»».
} 
de llegar a Roma. El motivo por el cual Naharro ha tenido que abandonar España no es conocido. Las hipótesis varían. Algunos toman en consideración la posibilidad de que Naharro fuese judío (Gilman, 1963-64, 39) ${ }^{49}$ o moro converso (Lihani, 1979, 158-159). En tal caso sería un español más que habría abandonado su país tras la expulsión dispuesta por los Reyes Católicos en 1492.

A partir de 1508 lo encontramos en la corte romana. Algunos lo ven bajo la protección de Giulio de' Medici, otros del cardenal Bernardino Carvajal. Es probable que gracias a la mediación de este último haya podido representar sus piezas teatrales. El Cardenal Bernardino Carvajal ${ }^{50}$ ocupa un lugar interesante en la historia de la vida pontificia, y en particular, en la época de Julio II. La historia lo recuerda por el Concilio cismático convocado, en el año 1511 en Pisa, con el pretexto de reforma y destitución del Papa. Zimic (1976) ve en Julio II el blanco de los ataques satíricos de Naharro. Cierta coincidencia de pensamiento del cardenal y del dramaturgo confirmarían esta hipótesis. Mazzei (1922, 54), por el contrario, opina que Naharro llega a Roma en 1513, después de la muerte de Julio II y en compañía siempre de Carvajal. También cree que permanece en la ciudad papal hasta la muerte de León X en 1521 (56). Dicha suposición se deduce de las semejanzas encontradas entre las comedias Calamita y Aquilana con la Calandria de Bibbiena y, asimismo, I suppositi de Ariosto, obras representadas en Roma en 1518 y 1519. Luisa de Aliprandini (1985, 11, nota. 22) no comparte esta afirmación y señala que dichas comedias se habían representado con anterioridad en la

\footnotetext{
${ }^{49}$ Américo Castro también deja abierto el camino a la interpretación de que Torres Naharro fuese un converso. En La realidad histórica escribe: «No se sabe nada acerca de los orígenes familiares de Torres Naharro, ni de los motivos que lo mantuvieron alejado de España. Su estilo mordaz, sus censuras de la vida eclesiástica en Roma, el modo «intelectual» de enfocar ciertas cuestiones, junto con otras circunstancias, parecen indicar que Torres Naharro fuese uno de los tantos conversos del judaísmo que hallaron refugio en Roma» (México, 1962, 185).

${ }_{50}$ El mismo origen extremeño lo relaciona con Naharro. De noble familia española y sobrino del famoso cardenal Juan Carvajal, tiene una rápida carrera eclesiástica. Llega a Roma durante el pontificado de Sixto IV, ocupa sedes importantes en la época de Inocencio VIII y es embajador español durante el papado de Alejandro VI. La actitud rebelde demostrada en el Concilio de Pisa le cuesta la excomunión y el retiro a Francia. Después del 1513 - ya Papa León X - vuelve al estado pontificio y es cardenal-obispo de Ostia y decano del Sacro Colegio. Muere en Roma en 1523.
} 
ciudad $^{51}$. Lo cierto es que el período romano es el más fecundo en la vida del autor. La vida dinámica, rica, de la corte romana constituyen un estímulo único para la creación de sus obras.

En 1517 Naharro se encuentra en Nápoles donde el editor Jean Pasquet publica su Propalladia. Su partida de Roma ha sido explicada de distintas formas: para el crítico francés, Marcel Bataillon, se debe al poco éxito de sus comedias. Desde Moratín y Nicolás Antonio se habla, en cambio, de una partida obligada debida a la sátira anticlerical de sus textos. Quién va más allá es Stanislav Zimic, que supone la existencia de una enemistad entre el dramaturgo y Giulio de' Medici. Resulta difícil pensar que la curia romana se escandalizara frente a los contenidos de las comedias de Naharro. La sátira anticlerical era lo más común en la vida romana. Ningún acontecimiento grave debe de haber alejado a Naharro de Roma puesto que el Papa, en el privilegio, lo llama «dilectus filius» y de sus obras escribe «librum comediarum et aliorum operum, lingua hispana eleganter compositorum».

Con respecto a los últimos años de vida de Naharro, la crítica es más propensa en pensar en su vuelta a España o a la diócesis de Badajoz o a Sevilla bajo la protección de Baltazar del Río. En la edición sevillana del Cancionero general, 1546, aparecen publicadas unas Coplas en loor de la Santísima Virgen que testimonian la participación del extremeño a unas fiestas celebradas en 1530.

La imaginación, elucubraciones, a veces, pero fundamentalmente la falta de documentación cierta sobre la vida del autor han llevado a hacer, más de una vez, biografías noveladas del mismo.

Queda claro que la obra de Bartolomé de Torres Naharro ofrece un fragmento de vida y arte de un período tan complejo y rico como fue el romano en torno a los papas Julio II y León X. La corte romana, con sus virtudes y defectos, representa para el autor un estímulo incomparable. Las comedias «a noticia» Tinellaria y Soldadesca, el Concilio de los Galanes y cortesanas de Roma invocado

\footnotetext{
${ }^{51}$ Bernardo Dovizi da Bibbiena escribe la comedia Calandria en 1513, la representación romana de la comedia, con escenas de Peruzzi, se lleva a cabo en 1514 con motivo de la visita de Isabella d'Este; $I$ Suppositi de Ariosto, con escenas de Rafael, se representa en el 1519. No resulta que las comedias citadas se hubieran representado antes de las fechas mencionadas en Roma.
} 
por Cupido, el Capítulo III y la Sátira nacen de la observación directa del ambiente cortesano. Por otra parte, la espectacularidad de las representaciones y las reflexiones teóricas, en auge, en torno al quehacer teatral son una fuente de inspiración cierta para la escritura del primer texto de preceptiva dramática en lengua española que Naharro formula en el Prohemio de Propalladia. Uno de los nexos entre el ambiente romano y la vida de Naharro es el concepto de «fiesta» que trataremos a continuación.

\section{2. «Fiesta» y teatro}

No puede ser, pues, una simple coincidencia que los estudiosos del teatro concreten en el concepto de fiesta aquello que define el teatro en el Renacimiento: «unidad estructurante» (Cruciani, 1983, 16), que reúne las componentes expresivas de la sociedad. La fiesta coincide con la misma idea de acontecimiento teatral (y ya el mismo Burckhardt había destacado la importancia de las fiestas oficiales en la corte). Por otra parte, para Bajtín la fiesta es «el rasgo fundamental de todas las formas de ritos y espectáculos cómicos de la Edad Media» $(2003,14)$. Un mismo hilo conductor une, a través de los siglos, el hecho festivo con el teatro. Todos los ritos, fiestas y textos citados por Bajtín en su estudio presentan afinidades con el mundo del teatro. Los mismos ejemplos citados son utilizados por los estudiosos del teatro para expresar las fases evolutivas del arte teatral hasta la Edad Moderna. 
Tomamos aquí, como ejemplo, una ilustrativa página de Bomarzo $(1967)^{52}$, de Manuel Mújica Laínez, para introducir el carácter festivo que define a la Roma de comienzos del s. XVI. A partir de la descripción de un hecho histórico ${ }^{53}$, la visita del embajador de Portugal Tristán de Acunha, asistimos a la sugestiva atmósfera espectacular que reina durante el pontificado de León X, momento en el que Torres Naharro se encuentra en plena actividad dramatúrgica. El Papa de las cosas bellas, del arte ante todo, asiste al desfile de Abul, el esclavo africano de Vicino Orsini, que, sentado sobre los calcañares de Annone, el famoso elefante blanco pintado por Rafael $^{54}$, cruza el puente de Castel Sant'Angelo. «Su Santidad contemplaba, extasiado, a través del monóculo, desde la eminencia del castillo, porque constituía el espectáculo más fabuloso que se había ofrecido a sus ojos de catador de lo bello». Fasto, extravagancia, trasgresión pero, por sobre todas las cosas, una lúcida

\footnotetext{
${ }^{52}$ Capítulo II , “Incertidumbres del amor”, episodio sobre la corta biografía de Abul, págs. 101-103. «Abul obtuvo su compensación plena cuando se presentó ante León X, sentado sobre los calcañares, casi desnudo encima de la cabezota balanceada de Annone, en el centro de la comitiva que desenroscaba su fasto en el puente del Castel Sant'Angelo, y que Su Santidad contemplaba, extasiado, a través del monóculo, desde la eminencia del castillo, porque constituía el espectáculo más fabuloso que se había ofrecido a sus ojos de catador de lo bello. Iba la bestia prodigiosa, la primera de esa traza que aparecía en la ciudad desde la caída de los emperadores romanos, moviéndose pausadamente, entre el clangor de las trompetas y los pífanos, precedida por muchas damas e hidalgos vestidos de terciopelo escarlata, en pos de un moro que montaba un caballo blanco resplandeciente, y conducida por un sarraceno, pero quien en verdad la guiaba, dirigiéndole de vez en vez una palabra secreta, era Abul, el triunfante, Abul que brillaba allá arriba como una alhaja de obsidiana, de azabache y de rubíes y que con una mano acariciaba y sosegaba a un leopardo agazapado en el vaivén del lomo. Ese lomo sostenía, sobre la gualdrapa carmesí, un castillo de plata, con muchos torreones, uno de los cuales estaba destinado a la exposición del Santísimo Sacramento y otro llevaba un cáliz, y los otros varios cofres con ornamentos sacros. Seguían los mulos enjaezados, los felinos, los exorbitantes papagayos roncos y, detrás, los embajadores, en el medio de los cuales avanzaba el famoso Tristán de Acunha, conquistador de islas lejanas, cuyo rostro pétreo se burilaba entre la geometría cortante de las alabardas y los penachos de las aves encendidas, como si todo lo que se mostraba allí fuera un sueño suyo, el sueño de un vencedor de bárbaras tribus para Don Manuel el Afortunado, y como si aquel tapiz de las Indias, que desplegaba su policromía a lo largo del puente del Castel Sant'Angelo y que, cuando los participantes se asomaban a los parapetos, volcaba su enjoyado lujo en la inquietud del Tíber, tan experto en procesiones extravagantes, hubiera sido bordado con los hilos de los sueños del descubridor. Pero Abul iba más alto que él. Abul iba, con el leopardo, encima de la muchedumbre atónita, como si bogara en la proa de una mecida galera del rey de Portugal, surcando un mar de cabezas asombradas y sintiendo contra los flancos del navío imponente, en lugar de los golpes de los albatros y de las gaviotas, los aletazos de las aves selváticas del trópico, el papagayo, el guacamayo, el ara, que prolongaban alrededor su electricidad, su chispear alborotado, sus descargas de un azul de esmalte o de mariposa y de un amarillo de azufre. Partido el séquito portador de mensajes y de regalos, Annone quedó en la Ciudad Eterna al cuidado de Abul, en el Belvedere del Vaticano, a donde el pueblo iba a verlo danzar al son de los pífanos».

${ }^{53}$ Muchos relatores e historiógrafos de la época entre los cuales R. Gregorovius, L. Pastor, P. De' Grassi y Marin Sanudo, cuentan este acontecimiento.

${ }^{54}$ El elefante se encontraba en una de las torres del Vaticano, más tarde demolida para dar lugar a la construcción de las columnas de Bernini.
} 
concepción de la fuerza motriz de la teatralidad domina aquellos tiempos: la comunicación era un arte y la retórica ya una profesión.

El estudioso italiano Fabrizio Cruciani (1983) analiza, en detalle, los diversificados espectáculos que se llevan a cabo en Roma entre 1450 y 1550 . A partir de los mismos formula su propria teoría sobre el concepto de «teatro» en el Renacimiento. La fiesta, lo repetimos, es el concepto fundamental alrededor del cual se crea la idea de teatro: una «unidad estructurante», un espacio metafórico en el que se refleja una cultura que, por una parte, crea, pero que, al mismo tiempo, proyecta sus propios valores. Si tomamos en consideración la multiplicidad de manifestaciones y actividades teatrales del año 1513 en Roma, nos asombramos frente a la numerosa y diversificada producción que este estudioso nos proporciona: «A estrapolare, in quest'anno 1513, le forme dello spettacolo «per generi» troviamo il carnevale popolare e di tradizione, con le corse, le cacce di tori, i giochi, i banchetti, l'andare in maschera, le processioni; l'entrata trionfale con la trasformazione della cittá, il corteo processionale, gli archi di trionfo; le «hilaritates», con fuochi di gioia, distribuzione di ricchezza, spari, corte bandita e fuochi d'artificio; la festa ufficiale con orazioni, banchetti pubblici, allegorie e commedie. Si ha la restituzione del teatro antico, spazio e progetto; si ha la commedia, allegorica o in latino o tradotta, e la nuova commedia; e gli intermezzi; e la scenografia e prospettiva urbana; e i buffoni; e i trionfi. Si ha la presenza degli intellettuali come drammaturghi: nel senso specifico di autori di testi stricto sensu teatrali (dal Bibbiena al Nardi, dal Bonini al Grasso, da Juan del Encina a un fanciullo di 14 anni); e nel senso ampio di organizzatori di un programma, come nel carnevale fiorentino (e come, per la festa di Agone, lo sará Inghirami nel 1514 o Latino Giovenale Manetti nel 1536). Si ha la riflessione e la prassi sull'edificio teatrale e la scena, in fra Giocondo o nel teatro capitolino di ambito sangallesco. E si può continuare, isolando aspetti diversi degli eventi: o si può guardare l'evento spettacolo come prodotto complesso di cultura e leggervi dentro le articolazioni e le funzioni del teatro» (Cruciani, 1983, 11). Lo que deducimos de este fragmento es que la idea de teatro se presenta como la expresión de una complejidad cultural en la cual elementos múltiples e intrísecamente relacionados entre sí llevan a 
la conformación del mismo. Podemos decir que los banquetes, las ceremonias, las entradas solemnes, los entretenimientos, las fiestas, los torneos son, en este momento de la historia del arte escénico, el momento de encuentro social en los que se realiza el acontecimiento teatral. Y el significado cultural y antropológico que adquieren estos eventos son los que determinan y le atribuyen al teatro renacentista uno de sus significados más profundos: «oggetto di una storia del teatro rinascimentale è forse, più che la ricostruzione dell'evento, la complessità culturale di cui esso è coagulo e portatore» (15).

Este estudio destaca la importancia del rol de la fiesta y de la corte en la vida social del s. XVI y el teatro es una parte constitutiva de las mismas. El hecho teatral, -y con el mismo el texto teatral-, se introduce o más bien es parte fundante de una cultura global en la cual es el espectáculo, en el sentido más amplio del término, el que adquiere el mayor significado.

El año 1513 es, en varios sentidos, un año significativo en la historia de la ciudad de Roma. El 20 de febrero es nombrado Papa León X (1513-1521). Y con él cobra cuerpo el mito de la Roma renacentista, antigua y cristiana. Es conocida la gran expansión cultural que vive esta ciudad durante su pontificado. La personalidad de León X difiere, en muchos aspectos, de la de su predecesor Julio II (1503-1513); sin embargo, ambos convergen en aquello que fue la idea de una política cultural basada sobre la voluntad de difundir la cultura en todas sus formas. Las programaciones culturales, bien detalladas, que de estos pontificados se conservan, son un buen ejemplo. La cultura en general, y el espectáculo en particular, son instrumentum regni, propaganda celebrativa y persuasiva. Si el primer Papa es el que lanza la idea de un proyecto político y cultural de potencia universal, el segundo es el que la realiza a través de un proyecto cultural bien definido. Por lo tanto, es dentro de este proyecto cultural y político hegemónico que vemos, en los primeros años del s. XVI, una infinidad de manifestaciones teatrales que se realizan o bajo forma de 
celebraciones oficiales o de fiestas privadas en las cortes, o de fiestas ciudadanas por las calles ${ }^{55}$.

Resulta difícil trazar un dibujo que refleje todos los matices culturales que hacen a la Roma de aquellos tiempos. El mito de la ciudad se va construyendo junto con los varios acontecimientos del Papado ${ }^{56}$ y es alrededor del pontífice y de la curia que gravitan las estructuras sociales y culturales de la ciudad. Con cada cambio de Papa se generan cambios y la ciudad asume una nueva fisionomía acogiendo, cada vez, nuevos habitantes de distinta proveniencia ${ }^{57}$. Se trata, en realidad, de «una originale (e ancora poco indagata) forma istituzionale dello Stato (Prodi, 1982) e di qualificato internazionalismo, innervato della cultura cattolica e dell'antico» (Cruciani, 46). «Roma diventa sempre più, dalla metà del '400, internazionale per struttura sociale e sovranazionale per i gruppi di intellettuali che vi trovano occasioni e ragioni di lavoro» $(47)^{58}$. En este sentido, la cultura que se materializa en la fiesta (o

\footnotetext{
${ }^{55}$ El texto de Gregorovius Ferdinand sobre la vida espectacular en la Roma de León X, indica la heterogeneidad de los elementos culturales presentes en la vida teatral de esta época: una serie ininterrumpida de fiestas compuestas de elementos cristianos y paganos como mascaradas carnavalescas, antiguas representaciones místicas, historias romanas representadas con magníficos escenarios, procesiones y lujosas fiestas religiosas, representaciones de la pasión en el Coliseo, declamaciones clásicas en el Campidoglio y otras tantas fiestas más y discursos para el aniversario de la fundación de Roma. Todos los días había cabalgatas de cardenales, entradas de embajadores y príncipes con numerosas comitivas como ejércitos, y cortejos papales cuando León salía de caza a Magliana, a Palo, a Viterbo, con el halcón en la mano, perros que lo seguían y bultos pesados y filas de criados y el séquito de los cardenales y de los oradores extranjeros y el alegre enjambre de poetas de Roma y una caterva de barones y príncipes etc. (Cruciani, 1983, 380-381).

${ }^{56}$ A partir de Alejandro VI, luego con Julio II y León X se va afirmando la idea de la gran Roma, antigua y cristiana. En uno de los arcos de triunfo construidos el día de la investidura de León X está escrito: «Un tempo dominó Venere; le tenne dietro Marte, ora Minerva avrá la sua era». La referencia a las diferentes personalidades de los tres pontífices es clara. Alejandro VI fue cultor de Venus, Julio II cultivó la guerra adorando a Marte y León X se presenta como el pontífice de la Sabiduría, destinado a ser recordado, entre otras cosas, por la vida cultural que atraviesa Roma durante su pontificado.

${ }^{57}$ A comienzos del s. XVI, en Roma se encuentran, entre otros, muchos españoles que a raíz de las conocidas circunstancias históricas -la expulsión dispuesta por los Reyes católicos-, por una parte, y las estrechas relaciones políticas, militares, religiosas y culturales, por la otra, habían abandonado la península ibérica. Muchos de ellos habían llegado en los tiempos de los Borgia, otros se encontraban bajo la dependencia del embajador ante la Santa Sede, otros aún eran clérigos al servicio de los cardenales y de la curia. Roma es, en todo sentido, el centro de recepción y difusión de las culturas más distintas y los ricos comitentes -cardenales, embajadores, banqueros- aunque también aquellos personajes -rameras y bisoños - tan presentes en las comedias de nuestro autor proceden de distintos lugares y pertenecen a distintas nacionalidades (como lo ejemplifica la jornada segunda de Tinellaria con sus distintas expresiones linguísticas).

${ }^{58} \mathrm{La}$ presencia de dramaturgos en Roma es notable. A parte de la conocida permanencia en la ciudad de Juan del Encina, -cuya comedia, quizás Plácida y Victoriano fue representada en la casa del
} 
en el teatro) refleja, de alguna manera la cada vez más compleja composición de la ciudad y constituye una convergencia de los multifacéticos aspectos y comportamientos de la sociedad y, de este modo, es también una expresión de lo que en términos contemporáneos denominamos multiculturalidad - $\mathrm{y}$ también interculturalidad-, condiciones que la ciudad expresa a través de distintas formas.

Julio II muere el 21 de febrero de 1513 y el 11 de marzo será elegido el Papa Medici. Nos detenemos, como ejemplo, en la fiesta que caracterizó el fin del pontificado, es decir, el carnaval que celebra la apoteosis de las conquistas de Julio II, el conocido Papa-guerrero que durante su pontificado mostró más dotes de político y militar que de religioso. El plan religioso y el político coincidieron plenamente en su proyecto junto con el gusto por las artes y la promoción de construcciones de obras artísticas (recordemos las obras de Bramante, Rafael, Miguel Ángel, entre otros), descuidando, naturalmente, la edificación espiritual.

La fiesta se articula en una «muestra» de la ciudad (autoridades, corporaciones, jugadores) a través de un cuento por imágenes de los hechos políticos, en carros alegóricos y en el mito de Roma (los jóvenes vestidos con trajes antiguos), con narraciones de un médico de Florencia, de un cronista de Urbino, de un embajador de los Este. Se dan fiestas y comedias en la casa del cardenal Sanseverino y de Agostino Chigi (personaje que aparece citado en la comedia Tinellaria). El orador de Mantua, Stazio Gadio, registra el 10 de enero una cena con las «pazzie» de fra Mariano; en una carta del 11 de enero de 1513, informa que en la casa del

cardenal d'Arborea- y la de Torres Naharro, señalamos que, junto con Emanuel I de Portugal, llega a Roma Gil Vicente. Por otra parte, en la ciudad aparece la traducción italiana de la Celestina, (primera edición en una lengua extranjera), realizada por Alfonso Ordóñez, en 1506. Es interesante notar, visto el carácter 'licencioso' de la obra, que el traductor era familiar del Papa Julio II. Francisco Delicado trascurre algunos años en la ciudad y en su famosa obra La lozana andaluza bien narra la vida romana de entonces. Vasco Díaz Tanco se encuentra en Roma hasta 1527. Por otra parte, en las cortes se introducen y leen muchas obras en lengua castellana. Gran difusión tiene la lírica, desde las coplas, romances, villancicos, motes, invenciones, glosas hasta la poesía erótica y cortesana; se traducen libros de caballería como el Amadis; libros de costumbre y amor, como la ya mencionada Celestina y Cárcel de Amor, circulan los libros morales y de erudición de Antonio de Guevara, y los textos que comentan las guerras de Carlos V. Vale la pena recordar, poco más tarde, también a todos aquellos intelectuales al servicio o relacionados con la corte de Carlos V que en varias ocasiones visitan la ciudad como Garcilaso de la Vega, Juan de Valdés y su hermano Alfonso, Diego Hurtado de Mendoza, Juan Ginés de Sepúlveda etc. 
cardenal d'Arborea se representa una "comedia" de Juan del Encina 59 ; el 19 de enero se narra otra cena con danzas, bufones y músicas y dos comedias: una en latín, una en vulgar y cazas de toros en Campo dei Fiori, el 8 de febrero una cena con el cardenal de Mantua, otra comedia para lodar a los Gonzaga, carreras de búfalos y cerdos etc. (Cruciani, 1983, 8).

Poco después, más allá de la muerte del Papa, se sigue con el clima festivo. En el mes de marzo sigue la coronación de León X y en el mes de abril el solemne Possesso, ampliamente documentado y magnificado, con una cabalgata y espléndidos arcos de triunfo que celebran la nueva edad de oro ${ }^{60}$.

\footnotetext{
${ }^{59}$ La referencia se encuentra en una carta del 11 de enero de 1513 escrita por Stazio Gadio, orador mantovano en el séquito del Joven Federico Gonzaga y dice: «Zovedì a VI, festa de li Tre Re, il signor Federico (...) si redusse alle XXIII hore a casa dil cardinale Arborensis, invitato da lui ad una commedia (...) Cenato adunque si redussero tutti in una sala, ove si havea ad representare la comedia. Il predetto reverendissimo era sedendo tra il signor Federico, posto a man dritta, et lo ambassador di Spagna a man sinistra, et molti vescovi poi a torno, tutti spagnoli: quella sala era tutta piena di gente, e piú de le due parte erano spagnoli, et piú putane spagnole vi erano che homini italiani, perché la comedia fu recitata in lingua castiliana, composta da Zoanne de Lenzina, qual intervenne lui ad dir le forze et accidenti di amore, et per quanto dicono spagnoli non fu molto bella et pocho delettó al signor Federico(...)» (Cruciani, 363).

Juan de Valdés considera que se trata de Plácida y Victoriano, como así mismo Moratín cree que fue imprimida en Roma en el 1514. Por otra parte Carolina Michaëlis de Vasconcellos en «Nótulas sobre cantares e vilhancicos peninsulares e a respeito de Juan del Encina», RFE, 5 (1918) (337-66), considera que se trata de la Representación sobre el poder del Amor. F. Wolf y M. Manéndez Pelayo son de la opinión que se trata de la égloga ya citada en «Sobre Juan del Encina », La España Moderna, 7 (1895), (91-98). Para mayor información al respecto consultar, Introducción, en Juan del Encina, Teatro Completo, edición de Miguel Angel Pérez Priego, Cátedra, Madrid, 1998, segunda edición, (1516).

${ }^{60}$ «Un evento minuziosamente preparato e diretto, nel corteo e negli apparati, nei programmi iconografici dei letterati e nel lavoro degli artisti; un evento che divenne esemplare (e serví da modello per l'entrata in Firenze di Leone X nel 1515), in un trionfo del classicismo, e che ebbe appendici per tutto l'anno negli ingressi sfarzosi delle varie missioni di obbedienza dagli altri stati italiani ed europei (tra gli altri quello dell'inviato imperiale Matteo Lang)» (Cruciani, 1983, 8)
} 
Erasmo (en 1515) escribirà de León $\mathrm{X}^{61}$ como de un Papa digno de ser celebrado por haber restituído la paz al mundo (pax orbi restituta) contrariamente a su predecesor famoso por haber encendido sólo guerras. La esperanza, llena de ilusiones, lleva a Erasmo a contraponer la imagen de Julio, Papa de la guerra, a la de León, pontífice de la paz. Sin embargo, Roma bajo León X fue una fiesta continua. Dentro de un clima mundano por demás se desarrolla el gusto por las representaciones teatrales consideradas como expresión típica del placer. Las comedias de Plauto, la Mandragora de Maquiavelo o la Calandra del cardenal Bibbiena, representadas integralmente en el Vaticano, gustaban fundamentalmente por su carácter picante y escandaloso.

La dramaturgia de Torres Naharro se encuentra en estrecha relación con el período que concierne al pontificado de los dos papas mencionados. Por cierto, una de las comedias -Tinellaria- fue representada frente a León X, y, como ya lo hemos mencionado, el mismo Papa concede a Torres Naharro el privilegio para la publicación de su obra. Soldadesca, por otra parte, se escenificó probablemente en presencia de Bernardino Carvajal y de sus ilustres amistades: «it was no doubt performed in the palace of some prince of Church, probably after dinner, wich would explain the speaker's reference to those who still lingered over their drinks , Intr., 27, and may well have sobered the distinguished audience» (Gillet, 1961, 503). Asimismo, los críticos suelen ver en muchos de los textos del autor la personificación del Papa Julio II - Stanislav Zimic, en la Sátira y en la Soldadesca; y, en ocasión del episodio recordado en Bomarzo, Naharro escribe la comedia Trofea: uno de los tantos

\footnotetext{
${ }^{61}$ En una carta que escribe Erasmo al Papa (21 de mayo de 1515) especifica que «nosotros debemos combatir dos guerras». La primera en contra de los vicios, los únicos enemigos de la religión de Cristo. La segunda en contra de los bárbaros, los turcos, enemigos de la cristianidad y de la santa sede. La primera, es la más necesaria y, también, la más difícil. Ella depende de «nosotros» mismos y hay que tratarla con la máxima atención.

Escribe Erasmo sobre León X en Dulce bellum inexpertis,(970): «El papa León X, quien es un verdadero pacificador en esta tierra, nos exhorta a la paz... todos sus deseos, designios y empeños están dirigidos a unir en concordia a todos los que están unidos por la misma fe... tiene carácter bondadoso y sereno... trajo al papado una vida y una reputación sin mancha... no quiso el papado para sí... fue llamado... por una voz divina para traer socorro a un mundo abrumado por las largas convulsiones de la guerra».

A pesar de estos bellos propósitos que Erasmo deposita en la figura del Papa, León X no demostró durante su pontificado estar a la altura de la situación.
} 
divertimenti ofrecidos al huésped probablemente después de un magnífico banquete. Dentro de este ambiente mundano, con sus privilegios y defectos, Naharro busca sugerencias para la composición de sus comedias representadas, además, en el contexto de las tantas fiestas.

Cruciani distingue, entonces, los siguientes tipos de fiestas: fiestas de la ciudad que incluyen el carnaval, las carreras, las cazas de toros, los juegos, las procesiones, las entradas triunfales, los cortejos, etc.; fiestas de la cultura, en las que los hombres cultos celebraban la imagen de su rol; fiestas en la corte, que se celebraban en las variadas cortes de Roma: la del Papa, las de los cardenales, la de los embajadores, la de los nobles, en las cuales se celebraba el poder a través de entretenimientos organizados de arte y de placer, se exaltaba el mecenazgo y se exhibía el propio lujo y magnificencia; fiestas privadas, que giraban alrededor de las fiestas de la ciudad, de la cultura, de la corte y adquirían una dimensión burguesa (18-19). La fiesta en su conjunto, no en sus modos y elementos, es la forma espectáculo del Renacimiento que supera las parcialidades que la constituyen. El objeto fiesta se presenta como un espacio y un tiempo no cotidianos, como una unidad formalizante de acontecimientos, sistema pluralista de lenguajes y formas expresivas de por sí autónomas, espejo de la sociedad que se propone a sí misma. No se trata, por lo tanto, de reconstruir el objeto autónomo fiesta, se trata de usar a la fiesta en su valor conceptual e ideológico, de asumirla como unidad estructurante de las componentes expresivas de la sociedad, cada una con la propia autonomía (Cruciani, 16).

\section{Las «composiciones romanas» de Torres Naharro}

Con la denominación de «composiciones romanas», como ya lo hemos mencionado, nos referimos a aquellos textos cuya acción se desarrolla en la ciudad de Roma. Aludimos, pues, a las comedias «a noticia», como asimismo a los textos cuya 
temática se refiere a acontecimientos o personajes relacionados con la ciudad papal. A continuación, analizaremos las comedias Soldadesca y Tinellaria y nos detendremos, en algunos aspectos, a nuestro parecer, interesantes de la comedia Jacinta, no propiamente comedia a «noticia» pero cuya acción se desarrolla en las cercanías de Roma. En segundo lugar, nos centraremos en las piezas satíricas - el Capítulo III, la Sátira y el Concilio de los Galanes y cortesanas de Roma invocado por Cupido- que en muchos aspectos ilustran las reflexiones del autor respecto del contexto romano.

Cabe recordar que no existe una cronología atendible y convergente respecto de la fecha de composición (y representación en el caso de los textos dramáticos) de las piezas de Naharro - sea de las comedias, sea de las restantes obras tomadas en consideración. Solo podemos documentar con certeza la realización de la puesta en escena de la comedia Tinellaria a partir de la información que nos brinda la edición suelta de la misma, anterior, sin duda, a la publicación de Propalladia en $1517^{62}$.

En linea general, las discusiones que se han llevado a cabo en torno a las fechas de composición de las comedias específicamente $-\mathrm{y}$, por lo tanto, a los períodos a los que el autor se refiere en las mismas - toman como punto de partida la «Chronology» (1961, IV, 470-479) de los textos dramáticos de Naharro propuesto por Gillet y que, sin embargo, ha sido discutido por la crítica posterior. En cada uno de los apartados, dedicado al comentario específico de las obras, nos detenemos en las interpretaciones de críticos como J.P.W. Crawford, O. Green, M. Bataillon, S. Zimic, entre otros. Una excepción es la comedia Jacinta -caso específico que a nosotros nos interesa- en que Gillet sigue la propuesta de J.P.W. Crawford (1937). Gillet ofrece la siguiente cronología:

1. Diálogo del Nacimiento $1505-1507$

2. Comedia Seraphina 1508-1509

3. Comedia Soldadesca 1510

4. Comedia Trophea 1514

5. Comedia Jacinta 1514-1515

6. Comedia Tinellaria 1516

7. Comedia Ymenea 1516

${ }^{62} \mathrm{Al}$ respecto remito al punto 3.1 .2 , pp. 122-123, notas 78 y 79 del presente trabajo de investigación 
8. Comedia Calamita c. 1519

9. Comedia Aquilana (I) c. 1520; (2) 1523 [?] fecha acompañada por la nota: Cf. Note 2, p 478, above, on the inconsistency of this date. O.H Green. ${ }^{63}$

Cabe recordar que son diversos los catálogos y estudios anteriores al s. XX que brindan información sobre el teatro español del s. $\mathrm{XVI}^{64} \mathrm{y}$, en el caso específico, sobre Naharro. A partir de los mismos se fundamentan las interpretaciones posteriores.

En el presente trabajo de investigación, con respecto a las comedias «a noticia», apoyándonos, sobre todo, en la lectura que ofrece Stanislav Zimic que sitúa los acontecimientos narrados en el período del pontificado de Julio II, presentamos primero la comedia Soldadesca. Con respecto a Tinellaria, no existen dudas, como lo hemos ya mencionado, de que la comedia fue representada, por cierto, en presencia del Papa León X circunstancia que nos obliga, por lógica histórica, a comentarla después de Soldadesca.

\subsection{Las comedias «a noticia» Soldadesca y Tinellaria}

Naharro, en sus comedias «a noticia», teje situaciones a partir de hechos reales así como se lo propuso en el Prohemio de Propalladia. Narra de «cosa nota y vista en realidad de verdad». En el caso de Soldadesca, de la vida de los soldados mercenarios españoles en la Roma de comienzos del s. XVI; en el caso de Tinellaria, de los preparativos de un banquete en la cocina de un cardenal romano. Estas dos comedias, definidas muchas veces por la crítica como «cuadros de costumbre», describen con amarga, aunque incisiva, ironía las dificultades que deben enfrentar las

\footnotetext{
${ }^{63}$ Gillet aborda los problemas bibliográficos con extremo rigor en el tomo I de Propalladia and other works of Bartolomé de Torres Naharro (1943).

${ }^{64} \mathrm{Cfr}$. Bibliografía, puntos 2 y 3 respectivamente.
} 
capas más desamparadas de la sociedad. Los personajes pertenecen a un submundo dominado por las más bajas pasiones y, en sus expresiones, vemos mucho de aquello que solemos identificar con la imaginerie del realismo grotesco, como asimismo, con el mundo de la picaresca. Los personajes, que se destacan por su conducta inmoral y por sus bajos instintos, le permiten a Naharro hacer una reflexión aguda, y una crítica abierta-, sobre la injusticia social pero, fundamentalmente sobre la corrupción de la jerarquía eclesiástica.

Muchos son los aspectos comunes que encontramos en las comedias: el respeto de la estructura y de los criterios expuestos en el prohemio de Propalladia; las referencias a la cotidianidad que, de alguna manera, consolidan la idea de realismo en ambas comedias: el poliglotismo de los personajes -que se expresan en castellano, italiano, alemán, latín, portugués, catalán, vascuence, francés- llegados a Roma con la intención de obtener algún beneficio, la referencia a lugares conocidos sea en España, sea en Roma; las citas de personajes históricos; las alusiones a fenómenos sociales comunes en la época; la referencia a batallas realmente llevadas a cabo en aquellos años.

\subsubsection{La cuestión de Soldadesca}

La crítica del pasado ha puesto el acento sobre dos puntos centrales en esta comedia: por una parte, el realismo que la caracteriza en la descripción de las situaciones y de sus personajes, -según María Rosa Lida la obra representa «la primera tentativa de poner en escena el soldado español en Italia, y sin duda la única que aspira a la representación "viva, directa, libre, realística" que Croce echaba de menos en el teatro italiano» $(1958,274)$; por la otra, la comicidad con que el autor pinta alegres cuadros de costumbre sobre las peripecias de los ejércitos mercenarios según Menéndez Pelayo, comedia escrita «para arrancar fáciles carcajadas a León X» (1941, 343) y que constituye «el más antiguo cuadro dramático de costumbres y desafueros militares» (344). 
Moratín no tenía una idea muy distinta: «esta pieza, meramente episódica, no tiene particular interés, ni se busque en ella objeto moral, idea de la cual el autor estuvo distante; quiso únicamente hacer una pintura exacta de las costumbres corrompidas de una soldadesca disoluta, y supo desempeñarlo con facilidad y ligereza cómica» (1944 [1830], 184).

Sin embargo, en tiempos más recientes, la crítica ${ }^{65}$-nos referimos aquí a los estudios llevados a cabo por S. Zimic, Hermenegildo, entre otros- ha ofrecido otras lecturas de la comedia. Con respecto al marcado realismo que caracteriza la obra se puede, sin duda, afirmar que Naharro se inspira en personajes de la vida real, en los soldados españoles en Italia, aunque estos «referentes vivos, de carne y hueso, probablemente surgidos de su propia existencia personal, son reelaborados, recodificados en una comedia» (Hermenegildo, 1990, 160) con el fin de ofrecer una visión crítica del soldado español en la Italia renacentista. Por otra parte, Zimic, que considera esta comedia como una de las mejores piezas del teatro español de todos los tiempos, escribe que «además de ser una condena general de la mentalidad bélica y de los desafueros soldadescos, es simultánea y más específicamente una crítica al belicismo y a la política inmoral del Papa Julio II» (Zimic, 1977, 64). Agrega el crítico que Torres Naharro en sus comedias «se revela como un hombre penosamente consciente de la magnitud y gravedad de las lacras del mundo en que le toca vivir y que se propone, como fin importante de su existencia, exponerlas a la luz del día por medio de una crítica sensata y de una sátira a menudo genial, ideológica y artísticamente»1976, 49).

Los críticos encuentran cierta dificultad en definir el período en que se desarrollan los acontecimientos narrados. Algunos, (Zimic, 1977; Gillet, 1961) ${ }^{66}$

\footnotetext{
${ }^{65}$ M. Sito Alba (1984) ofrece una interpretación interesante de la comedia. Según el crítico, Soldadesca alcanza la culminación del teatro histórico. Se detiene, específicamente, en la identificación de algunos personajes encontrando sus referentes en personalidades de la vida real. Toma menos en consideración los aspectos cómicos del texto para subrayar, en cambio, las intenciones críticas de Naharro.

${ }^{66}$ Gillet justifica del siguiente modo la fecha de composición de la comedia: «If the marching and singing exit of the characters in Gil Vicente's Exhortação da guerra (1513) was suggested by the final scene of the Soldadesca; if, on the other hand, Lucas Fernández was acquainted with the Soldadesca (through a printed edition or otherwise) when he wrote his Farsa o quasi comedia (Sold. III, 186; cf.
} 
ubican los hechos durante el pontificado de Julio II, el famoso Papa guerrero conocido por sus hazañas militares; otros, en cambio, durante el pontificado de León $\mathrm{X}$ (Menéndez Pelayo, Mazzei, Bataillon) ${ }^{67}$. Nos parecen plausibles las dos posiciones, aunque resulta, quizás, más convincente la interpretación de Zimic ${ }^{68}$. Más allá de la especificación del período, Naharro describe una situación de degradación de los ejércitos mercenarios que es común en ambos pontificados. De hecho, no aparecen alusiones concretas a uno u otro Papa en la comedia.

Martinez de la Rosa $(1827-30,195)$ escribe que La Soldadesca «se reduce a representar una recluta de soldados, semejante a la que se ve en algunos sainetes, pintada con verdad y con gracia, pero sin trabazón en las escenas ni verdadero plan dramático». La palabra sainete, utilizada, quizás, por el crítico con cierto menosprecio literario, denota aspectos de la obra que consideramos reveladores. Sin querer ir demasiado lejos en la historia literaria cabe quizás la pena recordar que, en muchos casos, el sainete se ha expresado a través del lenguaje grotesco. Basta recordar los sainetes de Arniches o el mismo grotesco criollo argentino, Discepolo, o, más aún, la hipótesis lanzada por Vicente Zamora según el cual Luces de Bohemia de Valle-Inclán se habría inspirado en una «literatura de arrabal», es decir en una forma de sainete paródico - La golfemia de S.M. Granés, en realidad una parodia de $L a$

Aur vol. I, p. 83, note), which was published in 1514, the parallels in question may be held equally well if not more justifiably to point to the early part of the year 1510, when the Holy League was about to reveal a new European alignment, rather different from that of the League of Cambrai of 1508 and directed -this time- against the French. The year 1510 would also be consonant with the fact that the battles of Cerignola and the Garigliano (1503) are mentioned in the play (I, $153 \mathrm{f}$.), but not the battle of Ravenna (1512), which had even wider repercussions (Epist. IV, 88, note)» (1961, IV, 473-474).

${ }^{67}$ Menéndez Pelayo (1941, 295, nota 1) indica que la Soldadesca fue escrita en 1514, a juzgar por los versos 1107-1126 de la cuarta jornada. Bataillon, por otra parte, discute la posición de Gillet: «Bien fragiles sont les indices que la Soldadesca ait été lue par Gil Vicente avant 1513 et par Lucas Fernández avant 1514. Et si les soldats espagnols de cette comédie parlent des batailles de Cerignola et du Garigliano (1503) mais non de celle de Ravenne (1512) 'wich had even wider repercussions', il suffit, por se l'expliquer, que les premiéres fussent des victoires et la derniére une défaite des Espagnols. (...) rien ne défend de croire que ces deux tableaux ont été écrits coup sur coup vers $1516 \ldots \gg(1967,162)$

${ }^{68}$ «Nos parece evidente que toda la acción se sitúa en el papado de éste [Julio II] (1503-1513), porque Guzmán añora el tiempo de Alejandro VI (1492-1503). De desarrollarse los episodios dramatizados en la comedia en la época de León X (1513-1521), sería absolutamente inconcebible que Guzmán no lamentara la muerte de Julio II, tan notorio en toda Europa entonces, precisamente por su lamentable entusiasmo por las aviesas relaciones diplomáticas y por la solución militar de todo desacuerdo» (Zimic, 1977, 66-67). 
Bohème de Puccini. Quizás, sin quererlo, y sin comprender la estética de fondo de la escritura narrahesca, Martínez de la Rosa califica con el término sainete la afinidad del lenguaje de la comedia con lo grotesco.

En la obra de Naharro asistimos a la destrucción de algunas categorías de orientación en el mundo: el concepto de personalidad, el orden histórico, la coherencia lingüística, las leyes estéticas (lo bello, lo feo, lo cómico, lo trágico). Lo grotesco como sabemos está intrínsecamente asociado a lo tragicómico. Se trata de un género que mantiene un equilibrio inestable entre lo que es cómico y lo que es trágico, dado que cada género supone su contrario sin considerar la actitud definitiva (Pavis, 1990, 247). El mundo narrado por Naharro se caracteriza por su deformación, fundamentalmente moral y social. Se trata de un mundo sin armonía. Lo grotesco renuncia a dar una imagen armoniosa de la sociedad, reproduce miméticamente el caos y al mismo tiempo ofrece una imagen reelaborada del mismo.

Con respecto a la falta de plan dramático que denuncia Martínez de la Rosa consideramos que, por el contrario, Torres Naharro estructura las jornadas y sus escenas con plena conciencia artística y dramática. «Todos los detalles están empleados de manera eficaz, con el propósito específico de crear una situación en que se colocan unos personajes representativos, cuyas motivaciones se exploran de manera sugestiva» (Zimic, 1977, 86-87). El dramaturgo tiene bien claros los objetivos dramáticos y conduce con lucidez al lector a lo largo de la comedia.

El argumento de la comedia es muy simple. El Papa necesita un nuevo ejército de quinientos peones. El Capitán recibe el encargo de reclutarlo y con la ayuda de Guzmán y Mendoça, soldados veteranos, y del Atambor, encargado de pregonar la leva, juntan el grupo de mercenarios: Manrique, Juan, Pero y un fraile apóstata cuyo nombre es Liaño. Guzmán con un compatriota decide sustraer las remuneraciones que corresponden a los soldados y desertar. Después de una serie de peripecias, entre ellas 
la permanencia de los bisoños $^{69}$ en la casa del villano italiano Cola, la comedia acaba con los soldados que se marchan cantando un villancico.

Los personajes de esta comedia no se distinguen mucho, en sus comportamientos y actitudes, de los sirvientes de Tinellaria, como veremos a continuación. Encontramos en ellos un mismo impulso de fondo: mejorar su condición de vida a cualquier precio, y si es necesario, a través del engaño, de la burla y de la traición de los más cercanos. En el texto asistimos a una serie de «enfrentamientos», de «invasiones» de los espacios dramáticos de los distintos grupos de personajes (Hermenegildo 1990, 162). Los soldados veteranos -Guzmán, Mendoça y Manrique- tienen un amplio conocimiento de los engaños de la vida militar y, consecuentes con el cargo que ocupan, esperan, por sobre todas las cosas, el momento justo para embaucar al Capitán robándole el dinero invertido en esta empresa y huir luego con mujeres en busca de otra ocasión mejor. Los bisoños, en cambio, son soldados novatos que han abandonado la vida en el campo y que buscan en la guerra mejores condiciones de vida. Ignorantes y poco dúctiles en el idioma y las costumbres italianas son constante objeto de burlas y desprecio por parte de sus compañeros y de los italianos, rústicos, que los alojan.

El Capitán es el único personaje que se diferencia por el rango militar y al que todos, aparentemente, respetan; sin embargo, a pesar de su cargo, tiene como único objetivo engañar a los soldados quedándose con sus sueldos. El Atambor, por su parte, pregona la noticia del reclutamiento por los lugares más 'adecuados', es decir, por los burdeles y tabernas y, como los otros personajes, aspira, en esta empresa, a obtener los mayores beneficios posibles. Por último, el fraile Liaño abandona, sin ninguna rémora, su ropaje clerical para dedicarse a los placeres de la vida terrenal.

La invasión de los distintos espacios dramáticos por parte de los personajes se presentaría de la siguiente manera: el Capitán, con la complicidad de Guzmán y el Atambor, invade el espacio dramático de los bisoños, convenciéndolos para que entren en esta guerra. Guzmán, a su vez, se coloca en un espacio opuesto al del

\footnotetext{
${ }^{69}$ Croce explica el significado del término bisoño del siguiente modo: «(...) bisogno (cioè soldato di fresco arrolato) (...)» (Croce, 1968, 186-187).
} 
Capitán, complotando con Mendoça para robar los sueldos y escapar con sus amigas. Juan y Pero se enfrentan a Cola, pero también, Cola y Joan Francisco se oponen a Juan y Pero. El Capitán y Guzmán, al final de la comedia, «construyen un espacio dramático desde el que intentan robar a sus propios soldados y engañar al ejército papal» (162). Es decir, en esta comedia, todos se oponen a todos, creando diferentes redes de complicidad. Escribe Hermenegildo con respecto a los espacios dramáticos invadidos por los distintos grupos de personajes que se trata de «espacios diferentes, ocupados por personajes que se oponen mutuamente en torno a problemas cotidianos, banales, pero que en el fondo pertenecen todos a un mismo campo axiológico, el de los tristes militares españoles, que se oponen al campo axiológico de los señores de la guerra, al de la clase dominante, al del «sistema» encarnado en la figura del Papa» (162).

No faltan en esta comedia los elementos indicados en el capítulo III que hacen al vocabulario de la plaza pública. De acuerdo con la preceptiva narrahesca, la comedia se abre con un introito declamado por un rústico que se expresa en el lenguaje pastoril llamado sayagués. Según la crítica, Torres Naharro sistematiza el uso del pastor cómico - presentador del espectáculo- en los introitos de sus comedias. Los pastores, simples, bobos, graciosos cuyas características se enmarcan dentro del mundo de lo popular, son los que mayormente han sido considerados como manifestación textual del «loco festivo». El rústico de los introitos de Torres Naharro, (excepción hecha de la comedia Tinellaria) se enmarca dentro de esta tradición carnavalesca. Es «una manifestación más de la figura del loco carnavalesco» (Hermenegildo, 1990, 159) $^{70}$.

\footnotetext{
${ }^{70}$ Los críticos, desde ópticas distintas, se han ocupado de relevar problemas de fuentes, dependencias textuales, aspectos dramáticos definidos por el aspecto cómico del personaje del rústico. Sin embargo, la imagen del pastor que emerge de estos estudios resulta ser, según Hermenegildo, reductiva: «una máquina de producir comicidad», en el mejor de los casos, o un simple «enunciador de prólogos, introitos, loas, etc» (Hermenegildo, 1995, 40-41). Propone, por lo tanto, «reemplazar el estudio de las fuentes por el de la inserción dinámica de un texto en el entramado de signos que constituye una producción teatral determinada» (Hermenegildo, 1995, 9). Indica que es necesario considerar el texto literario, pero también el no literario, como una encrucijada en la que dialogan una serie de textos situados en un determinado contexto, distinto en cada momento de la historia. Prefiere observar «de qué modo una tradición textual pasa a convertirse en intertexto dinámica y dialécticamente inserto en la red sémica que constituye el corpus» (9).
} 
Los rasgos que determinan la estructura profunda del loco de la fiesta popular, en términos bajtinianos, es recurrente en el teatro español del s. XVI. El pastor rústico de los introitos de Naharro está cargado de aquellos signos que caracterizan la fiesta popular. A través del mismo se desencadena el espíritu de la fiesta carnavalesca, aunque dentro de los límites definidos por el discurso oficial. No debemos olvidar que el pastor, y los graciosos en general, sirven para reafirmar la verdad oficial dominante. El momento de la fiesta popular es, por lo tanto, una liberación controlada y limitada en el tiempo y en el espacio.

El pastor rústico se mueve en un espacio marcado por el espíritu cómico popular en oposición dialéctica al espacio serio y oficial de la corte. «La relación entre los dos espacios y la violación de la frontera que los separa constituye el desencadenamiento de la acción teatral justificada por la existencia misma de la dramaticidad. El espacio pastoril, enfrentado al espacio ocupado por el discurso oficial y sus signos correspondientes, constituye la iconización de una especie de «dualidad del mundo», de manifestación de la segunda vida, del «mundo al revés» sin el que no podría existir el mundo 'al derecho'» ( Hermenegildo, 1995, 67).

\section{Introito y argumento}

El pastor de la comedia Soldadesca abre un largo monólogo. «The most biting, bold, and contemptuous of all the prologues opens the play» escribe Gillet (1961, 503). En contraposición a la vida de los poderosos, exalta las virtudes de la vida sencilla. Sin dar más detalles sobre su persona comienza el introito saludando a los presentes. «Dios mantenga y remantenga / miafé, a quantos aquí estáis / y tanto prazer os venga / como creo que desseáis / ¿Qué hazéis? / Apostá que más de seis / estáis el ojo tan luengo, / y entiendo que no sabréis / adevinar a qué vengo» (vv. 19). De inmediato adopta una actitud desafiante que, por una parte, funciona como instrumento eficaz para atraer la atención del público, mientras que, por la otra, en 
cambio, establece una separación clara entre la extracción social de quien lo está escuchando y la suya. No sólo se dirige al público tratándolo como ignorante, «cada qual es bachiller / y presumen anfenito; / después no saben comer / ni desollar un cabrito / los letrados / que enfingen de necenciados» (vv.11-16)- sino también lo considera como posible estafador $-« Y$ apostalles he el cayado / que más de quatro estirados / no me hurten un ducado» (vv.17-19). El auditorio se ha reunido para escuchar al pastor, presume saberlo todo, -«todo quando presumís / es un aire loco y vano. / Véis, aquí todos venís / ascuchar este villano» (vv. 36-39)- sin embargo, no tiene los conocimientos que, él, sí posee -«Bovarrones, / que cegáis con presunciones, / y bivís todos ascuras, / que Dios reparte sus dones / por todas las creaturas» (vv. 40-44). Sin entrar en el problema de su descendencia familiar o de sus aventuras eróticas comienza a ironizar sobre las dificultades de quién ocupa espacios de poder. «Por provar, / ora os quiero preguntar: / ¿quién duerme más satisfecho, / yo de noche en un pajar, / o el Papa en su rico lecho? / Yo diría / qu'él no duerme toda vía, / con mil cuidados y enojos, / yo recuerdo a mediodía / y aún no puedo abrir los ojos» (vv. 55-64). Y aquí el objetivo de sus ataques es el Papa. En este sentido, individualiza los aspectos positivos de su vida contraponiéndolos a los del Papa -«Más verán / que dais al Papa un faisán / y no come dél dos granos, / yo tras los ajos y el pan, / me quiero engollir las manos. / Todo cabe; / mas aunque el Papa me alabe / sus vinos de gran natío, / menos cuesta y mejor sabe / el agua del dulce río» (vv. 65-74). El pastor duerme mejor en su lecho de paja que el Papa, come con más ganas, bebe el agua del río y fundamentalmente «vive como cristiano» trabajando con sus manos. A través de esta relación dialéctica con el público el pastor se sitúa socialmente y hace resaltar aquellas que son las virtudes de la vida sencilla en contraposición a la vida de los poderosos. «Yo, villano, / bivo más tiempo y más sano, / y alegre todos mis días, / y bivo como christiano, / por aquestas manos mías. / Vos, señores, / bivís en muchos dolores / y sois ricos de más penas, / y coméis de los sudores / de pobres manos agenas. / Y anfenitos / Que tenéis los apetitos / Tan buenos como palabras, / no comeriedes cabritos / si yo no criase cabras» (vv. 75-89). Es de notar que, como el mismo pastor nos indica, este 
auditorio que «chupa el mosto» probablemente estuviera asistiendo a la representación durante un banquete. - « Ora ver / quién me sabrá responder / destos que chupan el mosto: / ¿En qué mes suele caer / Sancta María de agosto?» (vv. 2529).

El rústico concluye su performance con la presentación de las cinco jornadas.

\section{Jornada primera}

Guzmán canta las glorias pasadas y lamenta la condición presente.

Un largo monólogo de Guzmán abre la primera jornada. En las palabras del personaje se va delineando la figura del soldado español experimentado en busca de trabajo por la Roma renacentista. «No sabéis adónde os ir, / todo el mundo está perdido, no halláis a quién servir / ni siquiera un mal partido. / ¡Gran dolor, un hombre tan servidor / que no halle un pan que coma! / ¿No vernía un atambor / por estas calles de Roma: / tan, tan, tan, / ea, ta, la, la, lan?» (vv. 210-220). Torres Naharro, escribe María Rosa Lida, ha desechado la intriga, desarrollando en una serie de cuadros la vida de la tropa en sus varios niveles: «por una parte, "el plático", con pretensiones nobiliarias que hacen reír a los otros españoles, pronto a reñir por un quítame allá esas pajas, veterano de campañas famosas y de la miseria de Roma y de las trampas del oficio, que emprende ya como aparcero del capitán contra sus camaradas, ya con sus camaradas contra el capitán, e incapaz de resistir a la tentación de hacer una jugarreta al bisoño» (Lida de Malkiel, 1958, 274-275). Para este personaje, la guerra se convierte en un instrumento necesario para sobrevivir: la paz es infructuosa, «sobra paz por la tierra» (v. 226), dice Guzmán, y a él, pobre soldado, es «la paz que le haze guerra» (v. 228). Tampoco le da resultado hacerse «prete» porque en este mundo perdido han desaparecido los «benefficios»y las «calongías». En su discurso se percibe, abiertamente, la nostalgia de los tiempos pasados en que el Papa Alejandro VI y su hijo César Borgia triunfaban sobre los pequeños estados italianos -«Desdichados, / que por los nuestros peccados / se llevó Dios su camino / al padre de los soldados, / 
el buen Duque Valentino» (vv. 254-258). César Borgia, «humano», «liberal y cortés», le ponía a Guzmán en las manos «veinte ducados al mes» (v. 268). Esta nostalgia define al tipo de personaje. César Borgia era un estratega lúcido -el príncipe de Maquiavelo que hubiera podido lograr el objetivo de unificar la península itálica- pero también un hombre evocado por su astucia e inagotable ferocidad. Todo el pontificado de su padre, Alejandro VI, se caracterizó por la corrupción moral y por la ambición de acrecentar el poder del Estado pontificio; sin embargo, paradójicamente, el recuerdo de Guzmán es melancólico: «quando yo le acompañava / las noches más sin abrigo: / tanto de mí se preciava, / que sólo se iva comigo» (vv. 260-264). Quizás, no es del todo errada la observación de Gillet cuando escribe con respecto a las glorias citadas por Guzmán que «essentially he [Torres Naharro] remains a Spaniard, mourning the Spanish dead, singing the Spanish victories...» (Gillet, IV, 426).

\section{Guzmán y el Capitán organizan la tropa.}

Entra en la escena el Capitán para comunicarle a Guzmán, con tono jovial y extremadamente gentil, casi hiperbólico, que trae una «buena nueva»: «el Papa mandó por mí / y hame dado esta conducta; / y al presente / me ha mandado expressamente, / porque no pudo ser antes, / que haga de buena gente / hasta quenientos infantes» (vv. 307-313). Alabando al compañero: «ya sé que por vuestra mano / cresce la fama española» (vv. 340-341), le informa que le dará el cargo de «sotacapitán», y el «alférez» será Manrique. Muy convencido de sí mismo, de su bondad y de su rol, subraya que de esta compañía no quiere dineros; al contrario, «Los dineros, / partildos los compañeros / y aved con ellos plazer, / que, pues que sois cavalleros, / ya me daréis de comer» (vv. 324-328). Se percibe en las palabras del Capitán demasiada ostentación de cortesía que se mostrará luego como falsa. La raposa de Esopo, escribe Zimic, tiene en el Capitán un discípulo brillante. «El recuerdo de la astucia en las famosas fábulas no es fortuito, porque toda la Soldadesca, en varios aspectos, invita al paralelo» $(1977,69)$. 
Guzmán, por su lado, se propone al Capitán como excelente soldado recordando sus éxitos en importantes campañas militares: en las batallas francoespañolas de Chirinola, es decir Cerignola (28 de abril de 1503), y la de, Garellano, es decir Garigliano (28 de diciembre del mismo año). Estas batallas resonaron durante largo tiempo por las pérdidas enormes de combatientes en ambos campos. Recuerda también que diez veces combatió en Bugía y que «en Trípol de Bervería / pudiera ser coronel» (vv. 352-353); ciudades que fueron conquistadas por los españoles en el año 1510. Poco a poco, se va esbozando en Guzmán la figura del soldado jactancioso, presumido y fanfarrón pronto a arrasar con todo para sacar algún provecho de la situación. El Capitán le ordena que vaya en busca de un Atambor y de otro soldado plático, Mendoça.

Apenas Guzmán se retira, el Capitán cambia de actitud y resultan claras sus verdaderas intenciones. Se informa con un nuevo personaje, el criado Tristán, sobre el plático preguntando con cierta ironía «¿que haze del cavallero?». Éste último responde, sin titubeos «su padre fue un açacán / y él ha sido un malcochero» (vv. 372373), además de ser un presuntuoso. «Ayúdenos a juntar / una vez la compañía, / que después en el pagar / perderá la fantasía» (vv. 380-383) dice el Capitán y comprendemos, así, que su propósito es quedarse con las ganancias de sus reclutas. En realidad, el Capitán no tiene ninguna estima de Guzmán, a pesar de la cortesía inicial, al contrario, con picardía y sagacidad hace todos los cálculos para sacar provecho personal. Se burla del plático: «y sé lo que an menester / estos Guzmanes bravosos, / muy peinados, / presumiendo de esforçados / y sirviendo por antojos, / pues con cada tres ducados / les quiero quebrar los ojos» (vv. 387-393); y le dice a su criado que el motivo que lo lleva a organizar el ejército del Papa es «procurar / de mejorar esta capa; / que suelen poco durar / aquestas guerras del Papa» (vv. 395-398). La alusión a la brevedad de las guerras la había ya hecho Guzmán en su monólogo. Estos personajes, no obstante sus riñas, comparten un mismo mundo de necesidades y, naturalmente, desean que las guerras sean lo más largas posibles. Zimic ve en estos versos una referencia satírica por parte del autor a los frecuentes y caprichosos 
cambios en los planes políticos de Julio II $^{71}$ que a menudo firmaba y quebraba alianzas con la inevitabilidad de muchas y breves guerras. Todos los hechos, según Zimic, confirman sólidamente la hipótesis de que la Soldadesca «se escribió con "el Terrible Papa" en la mente del autor» $(1977,71)$.

En la primera jornada se define el límite que separa a los soldados veteranos, por un lado, y al Capitán, por el otro. Se revela el juego de engaños entre los personajes donde cada uno defiende sus propios intereses. Los mecanismos que se instauran entre los personajes, en algunos aspectos, parecen preludiar a aquellos que se manifestarán en la literatura picaresca.

\section{Jornada Segunda}

\section{Entran en la escena los bisoños.}

Dentro de las varias voces que se expresan en la plaza pública Bajtín coloca al mensajero del ejército, o heraldo de armas, «que anuncia la movilización, el asedio, la guerra, la paz y cuyas proclamas se dirigen a todas las clases y corporaciones» (Bajtín, 2003, 158). A través de esta figura se percibe, de alguna manera, el aspecto histórico de la plaza. El Atambor narrahesco abre la segunda jornada evocando al Papa Juan y pregonando para juntar la leva: «Quién querrá tomar dineros? / A pozo Blanco se dan. / Tres ducados a los pláticos soldados / y diestros en renegar, / y a los bisoños onrados / dos y medio y el tragar» (vv. 461-467). El mensajero, veterano, él también, de ejércitos mercenarios, habla con el tono del charlatán de feria, «grita» con el tono propagandístico del vendedor ambulante y provoca, burlonamente, a los presentes. El primero que acude a la llamada del Atambor es Mendoça. Entre ambos

\footnotetext{
${ }^{71}$ Papa codicioso, vanidoso, con un desenfrenado deseo de poder, en un momento de fragmentadas y débiles alianzas políticas, inicia una fase guerrera. Promueve contra Venecia la Lega de Cambrai, en 1508, (con la adhesión del Emperador Maximiliano, Luis XII, el rey de España y el duca de Ferrara) y, en 1511, forma la Lega Santa (con Venecia, España, Inglaterra) para echar a los franceses de Italia. Con este acto favorece la sustitución de los franceses con los españoles en la península. Otra de sus batallas políticas es la convocación del V Concilio de Letrán (1512) en respuesta a la provocación del Concilio cismático de Pisa $(1511)^{71}$, en el que se encuentra involucrado Bernardino Carvajal, protector de Naharro.
} 
nace una discusión cómica en la que el plático se jacta de sus cualidades militares esperando, por ellas, una recompensa mayor: «Y aquesta disposición, / cabello, garbo y cintura, / ¿paréscete que es razón / passar por essa mesura?» (vv. 474-477). El Atambor le responde burlándose: «No sé nada. / Daros han paga doblada / si jugáis bien de piquer» (vv. 479-480) etc.; luego, busca una reconciliación justificando su atrevimiento porque ya había oído hablar de él.

La crítica, en general, no cree que sea decisiva la influencia de la literatura anterior en la aparición del tipo de soldado narcisista y jactancioso, -como Mendoça y Guzmán también-, en las obras del Renacimiento. Plauto y Terencio pueden haber inspirado a los fanfarrones de las literaturas modernas; «sin embargo, es también seguro que cada época en la historia tiene sus propios representantes vivos, de carne y hueso, como se suele decir, a quienes específicamente retrata el escritor, su contemporáneo» (Zimic, 1977, 75). Naharro habrá seguramente tenido como referentes a Pyrgopolynices y Thraso aunque los modelos de la vida cotidiana le habrán resultado seguramente más interesantes. María Rosa Lida subraya, por otra parte, que «las escenas bilingües (italiano estropeado por españoles, español estropeado por italianos) son buen reflejo de la admirable objetividad del poeta que, por añadidura, incluye en su comedia la visión italiana del soldado español, pero omite - precisamente porque su galería de personajes es verdadera- el figurón convencional del soldado fanfarrón» $(1958,275)$.

La alusión a los «soldados de Papa Juan» de los versos iniciales se refiere, según Gillet, al Papa Juan XXIII: «first a corsair, then anti-pope (1410-1415), seems to be the only one who might be prominently associated with soldiers. Incidentally, he was dropped from the list of popes in 1947. John XXIII is known to have organized a solid papal army under the best mercenary chief» (1951, III, 414). Más adelante agrega que «soldados de Papa Juan» puede ser interpretado, irónicamente, como soldados muy ancianos, es decir, muy pláticos. Zimic, en cambio, siguiendo su hipótesis ve una equiparación de los mercenarios en perspectiva de Julio II con los de Juan XXIII, «con lo cual, en efecto, se identifica la muy notoria piratería del antipapa del siglo XV con la del papa actual» $(1977,74)$. 
Aparecen los soldados subordinados, o bisoños, como explica Mendoça, que, cuando quieren pedir de comer, dicen siempre «Daca el bisoño, madona» (v. 512). El plático, los introduce, descalificándolos, con la expresión «bisoños grosseros»y agrega que «tienen presunción / y son bestias en sus modos» (vv. 506-507); son de origen campesino y no conocen la lengua italiana. El bisoño Juan, por su parte, como si hubiera escuchado a Mendoça, entra en la escena recalcando que «questo italiano / nunca lo pude entender» (vv. 531-532). En una escena tragicómica que linda con lo patético explica qué es lo que lo ha llevado a entrar en el ejército mercenario: la mujer lo ha echado de su casa y tiene que mantener a sus hijitos. El bisoño Pero, con respecto al comportamiento de la mujer, nota que tendría que haberla cargado de palos. «Peor fuera», responde Juan «porque nunca más la viera / y allí me hundiera a gritos, / después quiçá no tuviera / quien criara mis hijitos» (vv. 558-562) y comienza a contar cómo hace tres años dejó su tierra y ahora lo «traen con engaños / capitanes y diabros». Lleva una vida miserable durmiendo en los establos y la guerra es la única alternativa que le ha quedado: «Y por ellos [los hijitos], / como quien por los cabellos, / soy salido de mi tierra / y a buscar de mantenellos / en esta maldita guerra» (558-567).

Los bisoños son los personajes que parecen despertar mayor simpatía en el autor. Naharro pone en tela de juicio los ideales que motivan las guerras, supuestamente, "santas". Los hombres que constituyen los ejércitos mercenarios, no encontrando respuesta a sus necesidades en la sociedad, acceden a la profesión en busca de una situación mejor. Pronto, el bisoño Pero vuelve a la realidad inmediata y concreta. Quiere definir los sueldos con el Atambor. Con listeza advierte que «poner la vida al tabrero / bovería es de soldados, / mas yo digo que más quiero / la vida que tres ducados» (vv. 589-591).

Para completar el panorama de los hombres que constituían los ejércitos mercenarios, Naharro introduce a un fraile, Liaño, que bajtinianamente, será ridiculizado y degradado - no sólo por el autor- sino, también, por sus propios compañeros. Éste ingresa en la escena exclamando las siguientes palabras: «Sanidad / os dé Dios por bondad / y al alma después reposo. / ¿Queréis hazer caridad / a este 
pobre religioso?»(vv. 608-612). Los presentes reaccionan con cierta agresividad hacia el fraile. Percibimos en ellos el rechazo del personaje como representante de una categoría cuya conducta religiosa se demuestra hipócrita, exterior y desviada: «Y os aviso/ que Dios no quiere ni quiso / que biváis vos de donaires. / ¿O pensáis qu’el paraíso fue hecho para los flaires?» (vv. 648-652). Y, de inmediato, las palabras del Atambor bajan al fraile a la misma categoría de los soldados: «Yo os prometo / qu'el soldado más pobreto / de quantos podéis hallar, / es oy a Dios más acepto / qu'el flaire más regular» (vv. 653-657). El mismo Atambor sugiere al religioso que abandone sus hábitos para unirse al grupo: «juguémoslos a tres dados, / aquí sobr'este atambor» (vv. 636-637). El fraile vacila, aunque no necesita mucho para dejarse convencer: «Dexadvos de iproquesía, / buscad, señor, un ducado. / ¿Cómo qué? / No vais vos contra la fe; / del resto, bien que pequéis, / luego yo os absolveré / quantas vezes vos querréis». (vv. 641-647). Al respecto Zimic señala que estos versos recuerdan muchas referencias satíricas e indignadas de Erasmo «a la facilidad con que se otorgan las absoluciones a cualquier crimen, cuando el confesor lo encuentre conveniente para sí, e incluso las promesas de absolución antes de cometerse el pecado» $(1977,84)$. El fraile se identifica rápido en el grupo adoptando los mismos códigos y proponiendo tomar sus hábitos «según usança moderna, / y allí los remataremos / en una sancta taverna» (vv. 695-697). Resulta ser claramente frágil la devoción religiosa de Liaño vista la rapidez con que se despoja de sus paños. Naharro desaprueba su conducta en estos versos y recalca nuevamente que los frailes «rezáis de mala gana / tomáis el ábito ayer / y renunciáislo mañana» (vv. 665-667).

Respecto al vocablo «moderna», utilizado por Naharro, Gillet comenta: «the flayre may felt that gambling his frock away for drinks proved him clever and up-todate... The word is manifestly an expression of pride in a new world» (1961, IV, 127). Por otra parte Zimic, considera que se está refiriendo a una práctica corriente «entre sus correligionarios, que él sin duda menciona como disculpa y aliciente para su propia decisión» $(1977,85)$. El autor, satirizando la actitud del religioso, se está refiriendo, específicamente, a una práctica de la actualidad. 


\section{Jornada Tercera}

\section{El Capitán se encuentra con los soldados y les ofrece un discurso monumental.}

El Capitán adopta un tono solemne -en el que recuerda que los honores se ganan con gran fatiga y que cada uno de ellos está obligado «a seguir tras su vandera / hasta morir o vencer» (vv. 710-711)- en el que se percibe cierta ridícula exaltación patriótica. Destaca la importancia de la responsabilidad individual, la fama ganada en el pasado que se debe defender, la lealtad, el honor personal. Sin embargo, detrás de tanta pomposidad y de tantos valores heroicos que salen de su boca esconde otras intenciones, la contracara de la verdad, es decir, el engaño y la estafa a los reclutas, que se exteriorizará claramente en las jornadas siguientes. Mientras se ajustan los sueldos el Capitán enumera a su tropa - «a los buenos y a los nobles / se les den, como es onesto, / sus moços y pagas dobles. / Después van / el mi Sotacapitán, / Alférez y Canciller, / los Cabos y el Capellán, / un Sargento y Furrier, / y aun siquiera / diez conpaños de vandera, / Pífaro y dos Atambores; / y aun la enseña toda entera / pagaré de mis sudores» (vv. 724-735)-, utilizando, así, un recurso frecuente en la literatura renacentista: las enumeraciones, que formaban parte del ambiente típico de la plaza pública (Bajtín, 2003, 159). Por otra parte, también hablando de las dificultades que se encuentran en juntar el dinero para la soldada el Capitán dice «Yo tengo que contentar / las personas singulares, / aunque lo sepa robar / de encima de los altares»(vv. 747-751). El robo poco tiene que ver con el honor y lealtad mencionada poco antes $\mathrm{y}$, menos que menos, robar de los altares en defensa de los cuales, se supone, están combatiendo. Los pláticos, por su parte, fingen lealtad y complicidad en las posibles tramoyas que han de hacer juntos. Guzmán, refiriéndose al refrán «Es más el ruido que las nueces» propone que cinco o seis soldados pasen varias veces ante la persona que da los sueldos para que el Capitán pueda cobrar como si tuviera un ejército más numeroso. Son cómplices y enemigos al mismo tiempo. Podemos decir que están condenados a este rol ambivalente. Los veteranos también esconden su tendencia natural a cambiar de actitud si las circunstancias lo 
requieren. De hecho, sigue una disputa entre los pláticos, Manrique y Mendoça, que transforma el tono triunfal y monumental del comienzo uniéndolo al tono jocoso de la plaza pública, al tono de las injurias, imprecaciones y blasfemias. La risa acompaña esta escena inicial de la tercera jornada dejando traslucir un fondo grotesco en las actitudes de sus personajes.

Esta jornada se caracteriza, también, por la escena cómica que se lleva a cabo entre los soldados bisoños y los villanos italianos en la casa de Cola. El Capitán encuentra a los bisoños y a Liaño. Según el Atambor «buena gente, / por los quales yo me obligo / que os servirán gentilmente» (vv.845-847). Y subraya, mostrándose hombre honesto, que querría «que les hagáis cortesía / sin que resciban engaño, / al menos por causa mía» (vv. 849-851). El Capitán los manda a alojarse en lo del villano Cola. Aquí surge un choque/enfrentamiento cómico entre los soldados bisoños y los villanos italianos debido a la incomprensión lingüística recíproca. Unos hablan en castellano, los otros en italiano. Asistimos, también, a la definición de los distintos caracteres que tienen los personajes y los distintos objetivos que los mueven en sus acciones. Los villanos, en un primer momento, se muestran complacientes hacia los huéspedes - «Quelo ch’a io vi darò / volentier, di bona voglia» (vv. 919920)-, por el contrario, los bisoños se sienten de inmediato «capitanes» y exigen con cierta presunción un lecho y buen comer.

Las incomprensiones lingüísticas nacen en torno al tema de la comida. Dice Liaño «Daca, danos colación, / saca algunas golosinas. / P: Mate, mate un buen capón / o qualque par de gallinas. / C: Non c’è niente. / J: Bastan diez, / quanto más veinte. / C: Deh, misier, non ho nesuna. / J: Tanto mijor, buena gente, / pues que tiene veintiuna» (vv. 899-907). A parte de la incomprensión entre niente-veinte, nesunaveintiuna, el juego de los malentendidos sigue con voglia-olla, roba-boba, nula-mula etc.. Además, el bisoño Pero queriendo demostrar que conoce el idioma italiano, pide al villano que mate un queso para comer, naturalmente mal descifrando el significado de la palabra «formaje»; más adelante Juan demanda que ponga «agua a rostir» etc.

Pero, el juego de las incomprensiones se tranforma en pelea cuando el villano Cola dice una frase que, para el lector del s. XXI, puede resultar algo inquietante, es 
decir: «Non tocate la fanciula» (v.956). Zimic, con su excesiva voluntad de ver en cada palabra de Naharro un acto de denuncia, interpreta esta frase escribiendo: «La indignidad de la acción, que el autor quiere obviamente destacar, lo es muchísimo más $^{72}$, suponiendo que la violada es la hija, en presencia del padre». En este sentido, también recuerda que Erasmo se refiere en sus obras (Dulce Bellum inexpertis) a la violencia de los soldados contra las mujeres. Y efectivamente, la reacción del padre demuestra una fuerte irritación - «iAy, vilani! / Non vi curate, marrani. / Anchora, si Dio vorrà, vi darò tanti malani / che so vi rencrexerà» (vv. 958-962)-, tanto que tiene que intervenir el aldeano Joan Francisco para calmar la situación ${ }^{73}$. Naharro puede haber querido marcar el aspecto referido a la violencia física ejercida por los soldados; aunque no creemos que esto sea con la intensidad crítica que interpreta Zimic. En el análisis de algunos pasajes, como por ejemplo éste, el crítico exagera, decididamente, con sus juicios e interpretaciones olvidando que en la Roma de comienzos del s. XVI eran muy pocos aquellos que se indignaban frente a una «violación», asesinato o cualquier acto caracterizado por una ausencia total de moralidad. Dudamos de que en esta escena haya sido «violada» la hija del villano. Resulta ser excesivo el realismo tout court que algunos críticos quieren ver en Naharro, olvidando que en esta comedia -como en Tinellaria- el lenguaje ambivalente grotesco se perfila a menudo. La escena de esta «fanciulla» debe de haber provocado en el espectador cortesano la misma risa que habrán provocado todas las otras escenas de las dos comedias que estamos analizando en las que Naharro lanzaba constantes provocaciones.

Joan Francisco calma a Cola manifestando la siguiente idea sobre los bisoños: « fa buon fogo, concia il leto, / dagli depo magnar e bere. / Simel gente / voglion questo solamente; lassa andar per una sera» (vv. 976-980) y continúa con una burla

\footnotetext{
${ }^{72}$ Zimic señala que Boughner, en The Braggart in the Renaissance Comedy, cree que Cola es un ventero, pero el texto no lo indica en ninguna parte (1922, 92, nota 39).

${ }_{73}$ «Los bisoños, perdida la esperanza de enriquecerse en Italia, se dan por felices con comer bien en el alojamiento que les ha señalado el Capitán, y no aterrorizan al posadero ni intentan robarle; en boca de éste se halla la única alusión a mujeres (III, 253): "Non tocate la fanciula", y, sin duda, no la tocan, pues en la queja que luego presenta, no figura agravio de esa clase. No es el posadero quien comete errores cómicos por no entender español, sino los bisoños, por no entender italiano» (Lida de Malkiel, 1958, 279)
} 
lingüística de los españoles. Los dos villanos se califican mutuamente con los términos «coglione» $\mathrm{y}$ «mincione» que bien denotan su cultura de pertenencia. No son tan inocentes como los pinta Zimic. Se bufonea Joan Francisco «iMajadieros! / Io tiengos muchos dinieros / en la Cúrdubas, Sibilias; / míos patres cavalieros, / siñores de las Castilias» (988-993) y pasa a demostrar, siempre a través de la comida, que conoce el castellano -como antes presumían entender los bisoños el italiano- «las cole vo dir caolata, / tuncinos vo dir presuto, / las oglia vo dir pignata» (vv. 10001002). El italiano de los villanos presenta algunas inflexiones dialectales que indica, además, su falta de cultura urbana. Al hacer hablar Torres Naharro a sus personajes en varias lenguas y dialectos quiere, no sólo ofrecer una imagen fiel de la realidad, sino expresar también el modo de ser y la pertenencia social de los personajes.

Concluye Cola diciendo «Sono certi spagnolaci / che no vaglion tre denari, / manigoldi, forfantaci, / naturali montanari» (vv.1019-1022) y se va en busca de ayuda para dar «cento bastonate» a los bisoños.

\section{Jornada Quarta}

\section{La trampa de los pláticos}

« (...) Esta jornada proporciona un caso admirable de anagnóris, en el sentido de que se ponen penosamente de manifiesto las verdaderas intenciones de los supuestamente leales soldados Guzmán y Mendoça, representantes simbólicos de todos sus congéneres» (Zimic, 1977, 98). Los pláticos planean desertar después de hurtar «una dozena de pagas» (v. 1041). Ambos se muestran avispados y se adjudican, con la actitud de quien ya conoce las vueltas del oficio, vocación para el engaño. Mendoça subraya que ya está «al cabo de todo». Guzmán sugiere acordarse 
los dos «para bien y para mal. / Y si van / las cosas del Capitán, / como vemos, a la clara, / vámonos luego a Milán, / a Génova o a Ferrara» (vv. 1055-1061). Argumentan la trampa apoyándose en la idea de que no hay que fiarse de capitanes: «Ya sabemos / cómo quanto dél avremos / no bastará para bragas» (vv. 1037-1039). En el tramar su fuga alternan consideraciones que provocan comicidad y que remiten a aquellos clichés o arquetipos de comicidad que se basan sobre la complicidad entre hombres en temas de mujeres. Nos referimos a los versos que indican la fuga de los pláticos con sus amigas: «Si podemos, / sendas hacas nos compremos / de razonable valía, / al menos, en que llevemos / a vuestra amiga y la mía»; Mendoça protesta: «Voto a Dios, / que yo quiero llevar dos / y no la tengo en dos higos» (v. 1072-1074); Guzmán replica: «Y una os basta para vos» (v. 1075), pero, «otra quiero para amigos» (v. 1076). Siguen burlándose sobre el tema hasta proponer llevarse un carro y hasta cincuenta «bellas». Al fin, se llevarán a una sacada del «poder de su marido» (v. 1096) y a otra «de cas de su padre» (v.1101).

La conversación cambia de tono y comienza una de las frecuentes reflexiones del autor sobre cuestiones que afectan el presente puestas en boca de los personajes. Así lo hace en Tinellaria, por ejemplo, cuando habla el personaje del Escalco -y asimismo, en varias ocasiones los escuderos- sobre la condición de pobreza en que vive, siempre en busca de beneficios que nunca llegan sino al alto precio de compromisos corruptos; o, en las piezas en que denuncia la actitud enviciada de la Iglesia y el proceder pecaminoso de quien la conduce, como, asimismo, en el caso del Capítulo, de la Sátira y del Concilio. En los versos que siguen los personajes reflexionan a partir de un discurso que los coloca exactamente en el límite entre ser considerados víctimas o verdugos de la situación. El tema que se introduce es el de las frecuentes guerras que implican a los pequeños Estados italianos disputados entre las grandes potencias. Guzmán comenta que «un hombre bien de creer / me dixo, y sé que no yerra, / que se quiere rebolver / una grandíssima guerra» (vv. 1108-1111). Entran en juego los genoveses, los «florentines», los venecianos, Milán, Ferrara, el Papa, el Rey, los franceses, el Emperador y los ingleses. No falta nadie. Las consideraciones que hacen los personajes al respecto se mueven entre la ingenuidad 
de quien vive en condiciones precarias y la maldad de quien ha entrado a formar parte de un sistema en el que gana siempre el más astuto. Los caracteriza una actitud afín a la de los futuros pícaros. Los personajes apelan a Dios para justificar sus pensamientos. «Que no ay duda», dice Mendoça, «sino que el tiempo se muda / d'ora en ora y Dios lo ordena, / porque la gente desnuda / se vistan a costa ajena» (vv. 1127-1131). En la lógica pícara de los pláticos resulta casi obvio recurrir a un orden supremo para librarse de responsabilidades. En la lógica del autor, comprendemos que está ilustrando una amarga realidad, condición social, fatal de alguna manera, cuya responsabilidad es atribuible no tanto a Dios cuanto al hombre. Mendoça justifica su conducta con la apelación a las condiciones sociales y a su mala suerte censurando la soberbia de los ricos, aunque el autor pone en su boca algunas reflexiones penosas sobre la realidad: «¿sabéis qu’es el dinero? / Una noche muy escura; / donde llega, paresce que luego ciega / la discreción en llegando, / y el buen camino nos niega / y al malo nos va guiando» (vv.1150-1156) ${ }^{74}$. Una actitud bondadosa se desprende de Mendoça. El personaje sueña cómo sería su generosidad si gozara de riquezas: «Si yo fuesse, / yo os prometo que supiesse gastar de galantería; si duque o conde me viese, / yo os diré lo que haría», etc. (vv.1167-1171). Muy poco dura su quimera. Guzmán con pocas palabras lo hace volver a la actualidad: «No os matéis. / Por agora bien podéis / partiros desse cuidado, / muy mejor es que penséis / de dónde avréis un ducado» (vv.1192-1196) ${ }^{75}$.

Los soldados no abandonan el tono burlón durante el diálogo: «que si al pobre la pobreza / haze bivir en estrecho, / que a los ricos la riqueza / no les tenga buen provecho» (vv. 1138-1141) o «Queréis ver / cómo este mucho tener / los que lo

\footnotetext{
${ }^{74}$ Los versos siguientes tienen el mismo calibre:

«iQuántos son / los que tienen discreción / quando pobres compañeros / y les falta la razón / como le sobran dineros! / ¿Por qué aquéstos / no cobran alegres gestos / y alaban a Dios por ellos, / y en pensamientos onestos / no despenden lo más dello?» (vv. 1157-1166).

También en otras obras Torres Naharro expresa pensamientos parecidos, como es el caso de la Epistola VII.

${ }^{75}$ Zimic respecto a este pasaje observa: «Toda esta escena, en que se satiriza la ética perversa, la envidia y el orgullo profesionales del maleante, se destaca por un finísimo análisis psicológico, que nos hace recordar, en varios momentos, a los residentes del patio de Monipodio, excluyendo la gracia que caracteriza a éstos, por supuesto. En efecto, los proyectos que Guzmán y Mendoça delinean después, representan un antecedente muy meritorio de tretas parecidas que encontramos con cierta frecuencia en la literatura picaresca posterios (...)» $(1977,99)$.
} 
buscan son locos? / Que a muchos mata el comer / y de hambre mueren pocos» (vv. 1142-1146). Para ratificar la alianza terminan la jornada burlándose del bisoño Juan al que le sugieren enjabonar la pancera del uniforme. El concepto de diversión que manejan los personajes se funda en la complacencia de ver al prójimo en apuros. La escena, -que en el manejo de la comicidad recuerda el Auto del repelón ${ }^{76}$ de Juan del Encina- observada a través del tiempo, puede ofrecer, no sólo una lectura cómica, a partir de un preconstituido cultural y literario, situado en un tiempo histórico preciso. Desde otra óptica, distinta a la del cortesano, la escena adquiere un sentido más bien tragicómico. Lo que aquí relevamos es el punto de vista de la percepción de la historia que, seguramente, no es la de los bisoños, sino la del cortesano, el cual se desinteresa del fondo trágico que se esconde detrás de la burla de los personajes. Toda comicidad esconde siempre, pero a su vez revela, una parte de la realidad que generalmente no debe ser contada.

\section{Jornada Quinta}

\section{Los engaños continúan}

Juan ha tomado al pie de la letra el consejo de enjabonar la pancera. Deben escapar antes de que lleguen los villanos a darles las «cento bastonate» prometidas en la tercera jornada; sin embargo, el bisoño, en su ingenuidad, persiste en el acto del enjabonamiento. También, poco después, cae en la trampa que prepara Cola para detenerlos: conociendo la gula que caracteriza a los soldados novatos, los frena con una mágica palabra «¡Carne! ¡Carne!» (v. 1272). Los soldados, obsesionados siempre por el comer, interpretan este llamado como la invitación a un convite; se encuentran, en cambio, con los insultos y golpes de los aldeanos. Y aquí, identificándose con el rol

\footnotetext{
${ }^{76}$ El texto trata de la burla de un grupo de estudiantes contra dos aldeanos que van al mercado. Allí son maltratados tanto que deben abandonar sus bienes y escapar. Estos desventurados no sólo, por efecto de una broma, han perdido sus productos y sus burros, sino que uno de ellos, si no recupera el burro, deberá pagárselo al amo y esto significa perder la ganancia de un año. El sentido del tema se reduce al del villano que baja a la ciudad y es objeto de burlas.
} 
que han asumido, imploran, sumisos, que no los golpeen y que los dejen en nombre del Comendador Solís, del Visorrey y del Rey «Hombres son tan d'estimar, / que por justicia y por ley / te lo sabrán demandar» (vv. 1293-1295). Al fin, se supera el litigio entre Cola y los bisoños con la intervención del Capitán. Éste juega una función de intérprete lingüístico y de mediador, diríamos hoy, cultural. Escucha con atención a los villanos que lamentan todos los agravios sufridos y, en un italiano aparentemente correcto, persuade a los mismos para que también se alisten en el ejército. Es de notar que el italiano hablado por el Capitán se distingue por su estructura correcta, aunque con inflexiones dialectales, del italiano grosero de los bisoños. «Lassa fare, / che ti voglio far pagare / fin al ultimo quatrino, / anche farò castigare / quel manigoldo sassino, / Viene qua; io voglio, si Dio vorrà, / far una poca de gente; si a voi altri piacerà, / vi pagarò gentilmente» (vv. 1346-1355). Subraya Zimic que «al hacer Torres Naharro hablar a sus personajes en varias lenguas y dialectos, se muestra fiel a la realidad, no sólo en el sentido de asociar un individuo con el dialecto o idioma nacional correspondiente, sino en su intento de relacionar debidamente la forma expresiva con el modo de ser de un personaje, en el aspecto social y anímico» (1977, 97-98).

Resulta interesante recordar que, en la comedia Trofea, el autor realmente introduce la figura del traductor -«un interprete verná / que entiende bien su dezir, / y al Rey ha de referir / lo que cada cual dirá» (vv. 259-262)- como acto de cortesía hacia el huésped ilustre.

A la aparente integración final del ejército que se prepara para desfilar ante el Papa -que quiere ver a «quien da su dinero»- sigue una nueva alianza que quiebra el orden apenas establecido. El Capitán manda que todos se retiren para quedarse a solas con Guzmán: «dejadnos hablar un poco». La comedia, en realidad, acaba así como había comenzado: los dos personajes quieren organizarse para sacar más dinero a los soldados, cobrando más por los «cosaletes», sacando más «petos» y exigiendo un «furrier», un «capellán» y un «barvero». Es decir, los dos personajes que toman los acuerdos al comienzo de la comedia terminan siendo los cómplices más fuertes en el 
engañar a los reclutas, robarles y sacar provecho del ejército papal ofreciendo, en cambio, un conjunto de personajes degradados.

La comedia Soldadesca es una sátira de la guerra y las ideas que, al respecto, tienen los individuos que la ejercen. El autor pinta los excesos y el clima degradado de los ejércitos mercenarios de entonces. Un villancico final cierra la comedia. Todos los soldados, pláticos y bisoños, se ponen en marcha para desfilar ante el Papa:

¡Sus, al orden, tres a tres!

Cada qual tome su lança.

iSus, sus, sus, al ordenança!

Las grullas en su bolar

por orden las vemos ir,

los pueblos para durar

por orden se an de regir:

pues ordene su bivir

todo aquel que seso alcança.

¡Sus, sus, sus, al ordenança!

1450

La sátira narrahesca brota nuevamente. Hace sonreír la apelación al orden civil en boca de los mercenarios. El villancico final «viene a escenificar la irremediable presión que ejerce el sistema sobre la miserable existencia de los soldados, enzarzados entre ellos y siempre listos para aceptar un triste modo de integrarse en la sociedad sacando dinero a la gente que los contrata para seguir arrastrando una vida miserable» (Hermenegildo, 1990, 166).

\subsubsection{La cuestión de Tinellaria}

Tinellaria respeta la estructura y los criterios expuestos en el Prohemio de Propalladia: introito, argumento y cinco jornadas. Contrariamente a lo indicado en la introducción preceptiva, un coro de personajes (más de 20) da vida a la comedia, «el subjeto della», se justifica el autor, «no quiso menos». Se trata, pues, de una 
comedia-mosaico, un heterogéneo pero funcional mundo de «voces» que habla de vicios: envidia, lujuria, pereza, traición, pero fundamentalmente de hambre (no vicio propiamente). El argumento consiste en la descripción de los preparativos de un banquete en el tinello de un cardenal romano. El núcleo de la narración está constituido por la glotonería y el buen beber de los sirvientes en presencia de la corte: « los mayores / que aquestos grandes señores / ora pudieran venir, / de cómo sus servidores / piensan otro que en servir / ¿Quán continas / las tardes y las matinas / los veréis haziendo guerra / a las pobres cantinas / hasta meterlas so tierra! » (vv. 6574). «Y acontece / que la familla [del Cardenal] padece / por esta descortesía, / y aquéllos, según paresce, / se emborrachan cada día» (vv. 149-153). Los instintos básicos, animales, del ser humano, la brutalidad, la grosería, la ignorancia son el recurso que Naharro utiliza -también en el sentido que les dará Bajtín- para describir el degrado de la curia y de un ambiente secundario del palacio renacentista.

\section{Introito y argumento}

Entre elogios, juramentos y reflexiones agudas se abre la comedia Tinellaria, comedia atípica en varios aspectos: el mayor número de personajes es uno de estos aspectos; el introito declamado por el mismo autor, otro. En el caso de Tinellaria, el autor abandona la figura del rústico como presentador del espectáculo y se propone a sí mismo. Ya Gillet había subrayado esta circunstancia, más tarde sondeada por Luisa de Aliprandini. La expresión «recitada esta comedia Tinelaria», que aparece en el fragmento de la dedicatoria al cardenal Bernardino Carvajal, publicada en la edición suelta de la comedia, nos informa, de este modo, que Tinellaria fue representada. Sin embargo, Torres Naharro no nos aporta ninguna información acerca de cuándo, dónde y en qué ocasión el Papa León X, invitado principal, -dato, este, último que no olvida de transmitirnos el autor-, y su primo Julio de' Medici habrían asistido al espectáculo. Luisa de Aliprandini $(1985,20)^{77}$ señala que críticos

\footnotetext{
${ }^{77}$ De Aliprandini supone que la dedicatoria a B. de Carvajal fue escrita cuando el autor estaba todavía al servicio del cardenal Giulio de' Medici.
} 
mayormente interesados en la vida y la dramaturgia de Torres Naharro y menos atentos a los problemas del espectáculo, se han ocupado de identificar más bien a los ilustres personajes y los posibles espacios que marcan este evento y no la situación cultural que el mismo representa. Los historiadores, que concuerdan en datar el acontecimiento entre 1515 y 1516, sitúan la representación casi seguramente durante una fiesta privada, un banquete, por cierto, que terminaba siempre con la representación de una comedia ${ }^{78}$. Nada nos impide pensar, (junto con Luisa de Aliprandini, 1985, 29-31), que Torres Naharro haya sido el mismo metteur en scène de la comedia. Existen ejemplos ilustrativos en este aspecto. Recordemos que Ariosto realizó 'la puesta en escena' de sus textos dramáticos en Ferrara, y que Juan del Encina, en varias oportunidades, dirigió y protagonizó a los rústicos de sus églogas. Es decir, estamos hablando de una de las tantas funciones que podía llevar a cabo el cortesano literato.

El autor utiliza el verbo recitar $^{79}$ con el significado de recitare $^{80}$ : los cómicos actúan en la escena y no se limitan a declamar, simplemente, los versos, costumbre, por otra parte, muy frecuente en los salones humanistas. Después de haber anunciado brevemente el tema de la comedia, agrega: «Si esperáis, / haremos como veáis / lo que agora oído avéis». El uso de veáis no tiene otro significado que el ver representado totalmente lo que se ha apenas expuesto y el mismo Naharro, suponemos, dirigió los pasos del espectáculo. De Aliprandini considera probable que hasta los propios sirvientes del banquete del Papa hayan sido utilizados por el autor,

\footnotetext{
${ }^{78}$ Gillet supone que la comedia fue representada en el palazzo Sisto Mellini en Roma, residencia entonces del Cardenal Bernardino Carvajal al cual la obra está dedicada (dato que se encuentra en Rodocanachi, 33), Luisa de Aliprandini, en cambio, piensa que fue representada en el palacio de' Medici. Podemos suponer, que el cardenal Julio de' Medici haya decidido ofrecer un entretenimiento al primo, el Papa León X, en su palacio, y que Torres Naharro haya sido el mismo metteur en scène de la comedia, (De Aliprandini, 1985, 29-31).

${ }^{79}$ En el diccionario de autoridades: «Referir, contar u decir en voz alta un discurso u oración».

En la comedia Trophea (Introito, 242, vv. 213-214) Torres Naharro escribe: «por esso os quiero anunciar, / si quigerdes atender, / que una comedia ha de ser / que os vernán a rescitar». En la dedicatoria de la suelta de Tinellaria «después de recitada esta comedia»; y el verbo se utiliza dos veces en el Prohemio «de donde la comedia queda mejor entendida y rescitada» $(1994,8)$ y «hauiendo respecto al lugar y a las personas a quien se recitaron» $(1994,9)$.

${ }^{80}$ Documentado ya desde el s. XIV con el significado de «Declamare de' comici sulle scene ne' teatri», Nicolò Tommaseo, Dizionario della lingua italiana, Milano, Rizzoli, 1977, XV, p. 552, acepción 3.
} 
presentador del espectáculo, para la representación. Naharro, además, ofrece informaciones precisas no sólo sobre el contenido de la comedia y su función (irónicamente didáctica: «Y a mi ver, / los que podrán atender / ganarán un paraíso / y no sólo un gran plazer, / mas un gran e útil aviso» vv. 60-64) sino, también sobre aspectos inherentes a la lengua («Yo’s prometo / que se avrán visto, en effecto, / de aquestas comedias pocas; / digo, qu'el proprio subjeto / quiere cien lenguas y bocas,» vv. 35-39) y, también, a la organización misma del espectáculo; en este sentido, la indicación final, con respecto a las dos horas de duración, resulta ser un indicio interesante («Del tardar, / dos oras puede durar, / poco más, según yo siento» vv.110113) como, asimismo, la referencia al «escaño», símbolo popular del teatro y de la plaza, mencionado al final del argumento («Al yantar / os podéis también llegar / los que yantado no avréis, / con un real singular / y un escaño en que os sentéis» vv. 164168). Naharro, pues, utiliza varias veces el verbo ver en el introito y argumento ${ }^{81}$ : «Su familla, / rica y grande a maravilla, / variis linguis que veréis, / bien que serán de Castilla / de siete partes las seis,» (vv. 134-138), «¿Queréis ver? / ora vernán a comer / en este sancto tinelo; / los que querréis attender, / no podrán tardar un pelo,» (vv. 154-158). Puede parecer obvio y hasta casi redundante detenerse en aspectos que aluden a la supuesta representación teatral y a Torres Naharro como presentador del espectáculo, pero, si llevamos dichos aspectos al contexto expuesto en el punto $1 \mathrm{de}$ este capítulo, la imagen que obtenemos de los mismos amplía y enriquece su significado.

Los versos iniciales, junto con los elogios del público ya citados, plantean, de inmediato, algunas cuestiones en torno al quehacer del literato: voluntad, doctrina y conveniencia son los temas tratados. Sin embargo, consideraciones como: «que en verdad, / bien que guíe voluntad, / si doctrina no acompaña, / ante tanta magestad / quien más osa más s’engaña» (vv. 10-14) o «Mas ¡andar! / Que la grandeza del mar, / do qualquier río se expande, / tal cara suele mostrar / al pequeño como al grande» (vv. 25-29) son, seguramente, de orden general, pero encierran, ya desde el

\footnotetext{
${ }^{81}$ «se avrán visto de aquestas comedias» y «si esperáis, / haremos como veáis / lo que agora oído avéis» los hemos apenas mencionado.
} 
comienzo, intenciones de reflexión seria en el tratamiento general de la obra. El autor, por otra parte, no abandona el tono juglaresco, como tampoco la degradación del lenguaje: «Cierto, creo, / convernía del deseo / hazer lenguas y razones, / como hazen, según veo, / de la pasta macarrones» (vv. 20-24), jugando, además, con intencionadas reminicencias clásicas, como el uso del latín «Ora, pues, / si mis versos tienen pies, / variis linguis tiren coces, / que vatibus hic mos est / centum his poscere voces» (vv. 30-34) y la referencia a Plauto «Pues, mis amos, / la comedia intitulamos, / a tinelo, Tinellaria, / como de Plauto notamos / que de asno dixo Asinaria» (vv. 90-94).

Naharro presenta al Gran Doctor llegado de Egipto recibido con honor por Papa Benedicto ${ }^{82}$. Los elogios se transforman rápidamente para dar lugar a la degradación de esta figura. El personaje cambia de cara y «Prestamente, / por ser su fama excellente, / fue Cardenal de San Jano / y llamado vulgarmente / el Cardenal de Bacano» (vv. 129-133). Como mencionamos en el análisis bajtiniano del capítulo III, la fusión de imágenes elogiosas y denigratorias conllevan la idea de un mundo en estado de permanente imperfección. La imagen dual, -no casual en este caso- como escribe Bajtín, es una imagen que corona y derroca al mismo tiempo $(2003,150)$.

En los versos siguientes el autor presenta el comportamiento, indecente, y las acciones de los sirvientes o familla «rica y grande a maravilla» del cardenal y subraya que se expresan en distintas lenguas: castellano, catalán, italiano, francés, portugués y latín macarrónico, como veremos en la segunda jornada.

\footnotetext{
82 De la provincia de Egipto 
Cierra el argumento el anuncio de que está por entrar (en escena) el credenciero, cuyo nombre, Barrabás, es todo un decir y, naturalmente, recuerda el atributo que caracteriza al personaje del Evangelio: «Barrabás era un ladrón».

Más no spero,

porque viene el credenciero,

Barrabás diz que se llama,

nombre como carne y cuero

tan conjunto con su fama.

Jornada Primera

La acción dramática corresponde a la preparación de la mesa para el banquete del Cardenal $^{83}$.

Barrabás está en la escena.

El credenciero entra echando maldiciones, injurias y reproches en contra de Lucrecia, «lavandera de consejo» y amante suya. Ella tarda en traer «las tovajas» limpias para poner la mesa mientras que él, trabajador, aparentemente de conducta intachable -«iSi piensa la scopetera / que me duermo yo en las pajas?» (vv.176177)- concentra todos sus esfuerzos para mantenerla dándole «pan y carne y vino, / que summa buenos quatrines» (vv.184-185). Barrabás, entre imprecaciones -como «scopetera», «necia», «spero llegar a verla morir de hambre»- e indicios sobre su persona - «que a mí no puede faltar / por mis dineros corambre»- le reprocha la falta

\footnotetext{
${ }^{83}$ A continuación, interpretamos la función del nombre Cardenal como nombre proprio.
} 
de aprecio por todo el bien que hace por ella. Según Zimic, este reproche esconde un doble discurso: Barrabás es un ladrón y está convencido de que lo más importante en esta vida es el precio de las cosas y «Lucrecia le pertenece como cualquier cosa comprada» (1976, 123). Sus imprecaciones, al fin, se deben sólo a la falta de puntualidad de la lavandera. De los pocos versos iniciales comprendemos que el mayor interés de Barrabás es robar para vivir bien, comer y beber. El sentimiento que nutre hacia Lucrecia responde exclusivamente a los intereses comunes -robar, en primer lugar-que los unen.

Entra Lucrecia y con esta breve introducción al tema que, de alguna manera, anticipa todas las relaciones engañosas y deshonestas entre los personajes del tinello, se desarrolla una ácida conversación entre ambos. El diálogo introduce elementos conocidos y de amplio impacto en el contexto hispánico. Nos referimos al mundo narrado en la Celestina y la Lozana Andaluza como, asimismo, al de la picaresca. La «scopetera» no admite haber llegado tarde. Recuerda sus dotes de juventud: belleza, lealtad y buena crianza y «como toda buena pícara, Lucrecia, sabe ensalzar y pregonar sus propias cualidades y simular gran ofensa e indignación ante la menor duda» (Zimic, 1977, 124). La respuesta directa y maligna de Barrabás hace mención a su proveniencia: ella viene del Burgo Viejo, donde están las lavanderas de consejo. Según Gillet, Lucrecia -no obstante su nombre que remite a otra figura legendaria ${ }^{84}$ más veces propuesta en el teatro castellano- presenta algunas características de Lozana. En su lamento/reproche, sólo en boca de Barrabás ella es fea y vieja; nadie en esta vida la ha maltratado como él; se ha dejado escapar a un mercader que podía mantenerla; ha negado por Barrabás hasta a la madre que la parió y dice «Bien me niembra / que quien en ruin tierra siembra / diz que coje mal y tarde» (vv. 268-270). La pelea se va atenuando y Lucrecia concluye exclamando que aquél de Barrabás, es

\footnotetext{
${ }^{84}$ Dionisio de Halicarnaso, Livio y Ovidio nos han transmitido la historia de Lucrecia, ejemplo de honor y castidad femeninos. Rina Walthaus en su tesis doctoral, La nieve que arde o abrasa - Dido \& Lucretia en el drama español de los siglos XVI y XVII, publicada en lengua holandesa, escribe: « Las dos mujeres mítico-legendarias resultan sumamente controvertidas: son descritas como modelos de constancia y fidelidad o como mujeres fáciles, como castas y santas o como apasionadas y lascivas. Fueran o no castas originalmente, en la literatura se han convertido en propiedad común, pasando de mano en mano, de pluma en pluma, idealizadas o degradadas».
} 
el beso de Judas (v. 337). Asistimos a un cambio de actitud: Barrabás busca la pacificación elogiándola y prometiéndole provisiones. Es el momento del intercambio de intereses, práctica corriente en la sociedad y motivo recurrente en las comedias. Lucrecia también demuestra que para ella el interés material es el único estímulo en sus relaciones «Ve, que tú me manternás, / mas otro me gozará» (341342) y «no lo puedo más ver / que al diablo del infierno» (vv. 346-347). Se trata de una venganza típica del mundo picaresco: «toda relación humana presupone un mutuo engaño, explotación y parasitismo» (Zimic, 1977, 125).

Con tono juglaresco Lucrecia, dirigiéndose al público, declara abiertamente, que Barrabás roba: «(...) si supiesse el Cardenal / por dónde van sus pañotas!» (351352). Y agrega: «mundo astroso,/ que a un traidor y a un malicioso nunca falta que le den, / si este fuera un virtuoso, / en su vida oviera bien» (vv. 358-362). Se refiere a Barrabás pero no sólo a él. Podemos decir que la crítica asume dimensiones más amplias: está dirigida también al Cardenal y con un efecto resonante involucra, igualmente, a los presentes. Entre un reproche y otro se despiden con una cita para la cena: pollos, con su tocino, pan blanco, buen queso, peras y vino, (v. 380) que Barrabás se ocupará de robar. No falta en esta despedida la siguiente actitud hipócrita: «B: Dios te guie, mi señora; L: y él te guarde mi señor; B: Contenta va la traidora / oy que le hize el favor» (vv. 394-397). Esta conducta falsa precede siempre al engaño; es más, tiende a encubrirlo para facilitarlo (Zimic, 1977, 125). Lucrecia tiene un comportamiento pecaminoso como, asimismo, Barrabás. Todos los personajes de esta obra parecen ser conscientes de su propia corrupción pero, a pesar de ello, persisten en su actitud. Es regla aceptada en el tinello que el engaño es un modo de actuar «lícito y merecedor de una recompensa correspondiente al empeño y a la ingeniosidad con que se efectuó» (126). El moto perpetuo de esta obra es, pues, el engaño y sus variantes que tienden a mostrar todos los «matices de la ruindad humana y de la corrupción social» (127). 
Sale Lucrecia y entra el Escalco ${ }^{85}$

La conversación entre los dos personajes de esta escena, Barrabás y el Escalco, gira en torno a tres cuestiones: las mujeres, la comida, los beneficios.

«Como cuentan mis vezinas, / mayormente Celestina, / diz que las viejas gallinas / hazen buena la cozina» (vv. 419-422). Son palabras de Barrabás cuando alaba las dotes sexuales de Lucrecia y, además, «Es de aquellas / qu'el hombre se sirve dellas / y bive y haze su hecho, / y aún más de quatro donzellas / no son tales en el lecho. / No te rías, / que en aquestas noches frías / ya me escallenta un poquito» (vv. 408-415). Naharro asocia al personaje de Lucrecia con la vieja alcahueta ${ }^{86}$. No sólo ejerce la misma profesión de prostituta, sino también de intermediaria junto con Barrabás. Este aspecto particular que caracteriza la actividad de la pareja aparece mencionado en dos momentos de la comedia. Cuando Escalco explícitamente solicita al credenciero que le consiga «una dessas putas viejas»-y no importa si «abadessa» o «prioressa»- como asimismo cuando fijarán una cita con el siervo Mathía para que encuentre a una muchacha. Este siervo Mathía, por lo dicho en el texto, mantiene una

\footnotetext{
${ }^{85}$ Del longobardo skalk que significa siervo. 1. Siervo encargado de trinchar las viandas en las mesas de los señores medievales y renacentistas; 2 . En la antigua corte pontificia, el camarero que servía en la mesa del Papa, en Vocabolario della Lingua Italiana, Zingarelli.

El nombre del personaje del Escalco está a mitad de camino entre nombre proprio y común. Nosotros optamos por tratarlo como nombre propio.

${ }^{86}$ La Celestina ha sido un punto de referencia constante para los autores de teatro del siglo XVI. En las obras se encuentran con frecuencia elementos de la obra de Rojas. Se reconocen similitudes entre los personajes, la trama, sino totalmente, muchas veces se asemeja y así mismo se reproducen las mismas situaciones dramáticas. Pérez Priego (1998, 65) escribe al respecto: «Habitualmente se imitará sólo un personaje aislado o un grupo de personajes (la tercera, la pareja de amantes, los criados), nunca el repertorio completo, y sí siempre convertidos aquéllos en tipos desprovistos de su condición de caracteres. La trama argumental, por su parte, será igualmente simplificativa y reducida a pura "comedia" con final feliz, renunciándose, en consecuencia, al desenlace trágico y a la compleja mixtura del expediente de "tragicomedia" al que había tenido que recurrir Fernando de Rojas. La imitación de las situaciones dramáticas se producirá también de forma aislada y circunstancial: se mantendrá siempre el escenario urbano, pero se escamotearán las escenas prostibularias, y será muy variable y diversa la imitación de episodios particulares, tales como las entrevistas de los amantes, sus quejas de amores, el ir y venir de criados, las intervenciones y conjuros de la tercera». El crítico (1993) agrega también que: «Lo celestinesco creemos que es aquí, más que nada, un fermento, un estímulo y un conjunto de posibilidades argumentales, a las que a veces recurren los dramaturgos de la época. Pero, como queda dicho, no llegó a ser nunca elemento único y dominante, ni su imitación se producirá de forma plena sino sólo parcial y episódica. Lo celestinesco podrá aparecer así en la «égloga», en la «comedia urbana», en la «tragedia» o incluso en el «auto» y la «farsa» religiosos.
} 
relación homosexual con el escudero Moñiz que le requiere «que cavalgue su muleto /quantas veces me pluguiere» (vv. 631-632).

Barrabás y el Escalco descubren, además, que Metreianes y el Canavario tienen juntas sus «bagassas»y, también juntos, roban (v.472). Aquí interviene otro elemento que Bajtín coloca dentro del lenguaje cómico grotesco: las refriegas y palizas. Deciden esperarlos a la noche y darles «mil bastonadas / que no sepan dó les vienen» (vv. 481-482). Durante todo el tiempo dramático de la Jornada, los personajes piensan en esconderse para almorzar y disfrutar, robando la comida de la despensa del cardenal. Zimic opina que todas las relaciones entre los criados son deshonestas. «Crear intereses es la estrategia que produce infaliblemente los resultados deseados» $(1977,131)$ como enseña Celestina. Los criados son cómplices y enemigos al mismo tiempo. Se trata de una competencia organizada entre ladrones, de cuya licitud no dudan. El Escalco y Barrabás se consideran con mayor derecho simplemente porque ocupan una posición superior en la jerarquía tinellera. Nosotros, más que cargarlos de tanta identidad definida preferimos considerarlos más bien como marionetas, elementos funcionales y usuales en la composición de la comedia. Se mueven dentro del código del lenguaje cómico-grotesco. La imagen que percibimos de estos personajes, se inscribe más bien y quizás, en la línea esperpéntica -aludida por Bataillon (1967, 143-70)- de la deformación grotesca de la realidad, de la presentación de los personajes como si fueran títeres, caricaturas absurdas y ridículas, dominadas, naturalmente, por un total distanciamiento afectivo y la ausencia de moralidad.

El tema eje de la comedia, alias, la comida es un ritornello. Metreianes (Maître Jean) debe preparar un almuerzo para ambos: faisanes, hígado, antepasto, salsa beata, caolada, malvasía (vv. 440-455). Las descripciones detalladas de las comidas son muy frecuentes en esta comedia. Mientras que, en este caso, el menú se distingue por su abundancia, lo que ellos servirán, más tarde, a los otros criados se distinguirá, al contrario, por su escasez. La escasez y tardanza de la comida son un tópico de la comedia. La intención de estos personajes es retirarse a la cámara de Barrabás para comer a escondidas. Asistimos, así, a la preparación de un banquete y 
al de dos contrabanquetes o, si queremos mejor, a tres preparativos concéntricos: el banquete del cardenal que los criados están disponiendo, el almuerzo de los tinelleros y el banquete real del cardenal que asiste al espectáculo. Podemos hablar de un juego de espejos, o apelando a una terminología más cercana en el tiempo, de metateatro o de teatro en el teatro. El procedimiento asume, desde el punto de vista performativo, una eficacia singular. Los criados se divierten y se emborrachan (en sus contrabanquetes) de la misma manera y contemporáneamente al Papa y a su corte mientras están mirando la representación. Por ello resulta interesante la observación de Luisa de Aliprandini en el sentido de que los sirvientes utilizados para el banquete real organizado por el Cardenal, son los mismos que aparecen en la representación del espectáculo.

Los personajes discuten un tema entonces actual: la venta de beneficios. Se representa, así, a través del mismo, un momento histórico, con las condiciones imperantes en la sociedad. La corrupción y deshonestidad en Tinellaria no quieren ser sino la imagen refleja de la corrupción de su tiempo. La ambición de bienes materiales como, asimismo de títulos eclesiásticos, aparece, así, en las jornadas siguientes.

El Escalco sugiere que la deshonestidad depende de las inadecuadas recompensas por los servicios rendidos, «Beneficios / ya no se dan por servicios» (vv. 544-545). Gillet (1961, vol. IV, 395; 413) y Bataillon (1967, 159-160) identifican las vicisitudes de este personaje con las de Naharro por las quejas referidas a la falta de salario que, de alguna manera, pueden remitirse a la vida del autor, como, así también, por la protesta frente a la venta de beneficios, que también, remite a su propia condición. Escribe Torres Naharro en el Prohemio: «toda mi vida pobre, ordinariamente pobre y, lo que peor es, ipse semopaganus, etc.» (1994, Prohemio, 7). «La queja de Escalco [...] refleja muy probablemente la opinión del autor mismo sobre el asunto de salarios apropiados, pero carece de buena justificación cuando la consideramos en el contexto total de la actuación del quejoso tinelero. Su afirmación sobre su 'afanar y servir' es, en efecto, una prueba evidente 
de su cinismo truhanesco, de fariseísmo prepóstero o, por lo menos, de un juicio terriblemente desquiciado» (Zimic, 1977, 133).

Un desajuste no menor se produce entre vida -reflejada en sus poemas autobiográficos- y ficción, cuando nos proponemos observar la posición de Naharro con respecto a las mujeres. Zimic se detiene también en este aspecto y subraya la actitud libidinosa que tiene el Escalco frente a las mujeres cuando entra en la escena, actitud que contrasta con la del autor, pues Naharro es un «amante sumido en la tradición del amor cortés» (1977, 128, nota 22). Observa que sus poemas autobiográficos revelan una amplia gama de sentimientos por parte del poeta enamorado, pero, en ningún caso, se vislumbra el deseo libidinoso hacia la amada. Más adelante, en el lamento del Escalco de la jornada quinta, también los críticos mencionados ven representado al autor ${ }^{87}$. Este pasaje ofrece «pruebas patentes de la ruindad moral del Escalco» (1977,178). La imagen que nos da Naharro del Escalco es de ladrón, corrupto, borracho, deseoso de grandes comilonas y de mujeres, como asimismo hábil en el vivir a expensas de los otros criados del palacio. Es decir, nada más y nada menos de lo que ofrece el mosaico de personajes que encontramos en toda la comedia. «La gratificación animal de sus más bajas pasiones resulta en grave daño para el prójimo» $(1977,179)$. Consideramos que el lamento forma parte de la

\footnotetext{
${ }^{87}$ ESCALCO ¡Ora Dios sea loado! 2075

Si la afectión no me engaña, yo soy el más desdichado que jamás vino d'España. ¿No me entiendo? Toda mi vida serviendo y pobre ansí como ansí, paresce que van huyendo los beneficios de mí. ¡Gran afán! ¿Y no me proveerán 
expresión coral de la obra en la que el autor, a veces, usa a los personajes para decir e igualmente negar sus posiciones. Podemos decir que la mentalidad astuta y corrupta del Escalco, su juego cínico con los otros tinelleros $^{88}$, responde al intercambio de engaños que se establece entre los personajes, no a la imagen refleja del autor. Zimic habla de «sicología perversa» y de «actitud paranoica» en la conducta del personaje. Sin exagerar con interpretaciones psicoanalíticas, creemos que el lamento del Escalco es una denuncia más dentro de la comedia, cargada quizás de un tono melancólico, aunque siempre satírico, propio del lenguaje y del estilo de Naharro.

La Primera jornada termina con el Escalco que llama a Barrabás y a Mathía. Se van finalmente a almorzar, «los bocados no son de perder» dice Barrabás.

Esta jornada puede ser ejemplificadora de las demás. Recordemos, resumiendo, que: 1. el instinto animal, embrutecido de los sirvientes, la referencia constante a las necesidades primarias, el comer, beber, fornicar, es decir, todo aquello que concierne a las necesidades que se realizan a través de las partes bajas del cuerpo caracterizan las actitudes de los personajes; 2. toda relación entre los tinelleros prevé el mutuo engaño. Crear intereses es la estrategia y todo ello remite al mundo de la Celestina y de la inminente picaresca. En este mundo encuentra su espacio la complicidad aparente entre algunos de los criados que esconde, facilita y precede el engaño; 3. el carácter especular entre la preparación de los banquetes de los criados y el banquete de quien está asistiendo al espectáculo es un juego (intencional y propio del teatro) entre realidad y ficción; 4. la crítica social, los

\footnotetext{
${ }^{88}$ El nombre común tinellero (una españolización del italiano) ha sido adoptado por los críticos para definir a los criados de la comedia de Naharro. Sin embargo, su grafía ha sido españolizada quitando la doble $l l$ propria del original italiano. Es el caso de Zimic que en su estudio utiliza el término tinelero/tineleros. En este trabajo de investigación, hemos preferido adherir al original manteniendo la doble $l l$.

Por otra parte, el mismo título de la comedia Tinellaria es una latinización a partir del italiano. Como lo dice el mismo autor en el Introito de la comedia:

«Pues, mis amos, 90 la comedia intitulamos, a tinelo, Tinellaria, como de Plauto notamos que de asno dixo Asinaria».

Y el mismo Naharro usa tinelo y tinello. Es un ejemplo, por demás interesante, para reflexionar sobre el relevo lingüístico, sobre el que nos alerta Bajtín.
} 
salarios inadecuados, la ambición de títulos eclesiásticos, todo esto forma parte de una denuncia por parte de Naharro embebida de una visión erasmista de los acontecimientos que dominan la época.

\section{Jornada Segunda}

A continuación: «la greguería políglota»

Es medio día. En la escena se encuentran Barrabás y Mathía juntos. Mathía tiene que «dar las baquetadas» pero comprueba que en la cantina no se encuentra nadie. Falta, además, lo principal: el vino para la comida. Los criados están llegando al tinello. Entra Francisco denunciando que seguramente Escalco -cuya fama es de borrachón a costas de los demás (a confirmación de lo que sostiene Zimic)- no está ayuno de vino.

Comienza la famosa escena coral y pluringüística en la que los criados llevan a cabo una discusión patriótica expresándose cada uno en su lengua: Fabio habla en italiano; el Tudesco, alemán, habla en latín; el Portugués en portugués; Miguel habla en catalán; el Vizcaíno en vascuence; el Petiján (petit jeune o Jean) habla en francés. Mathía es andaluz. Las opiniones en torno a esta ouverture de la segunda jornada han sido varias y variables. Moratín la considera confusa por temática y multitud de personajes aunque, con una intuición (genial) y paradójicamente cercana a la filosofía de Bajtín, la define «una greguería poliglota». Crawford, por otra parte, la considera una obra maestra del humor. Zimic, sin alejarse de la lectura general que hace de Naharro, subraya la intención crítica del autor.

Las actitudes grotescas se muestran desde el comienzo. Golpes, luchas con espadas, «pancadas», expresiones como «voto ao corpo de Deus», «aqueles porcos iudeus», «fi de cau» y otras delicadezas acompañan el tema inicial de la discusión: Francisco parece haber robado «il feno». En el discurso bajtiniano, los derechos y libertades del carnaval aseguraban la impunidad de los golpes, palizas y peleas y su 
significado se encuentra en estrecha relación con la destronización ${ }^{89}$. En esta escena percibimos algo expuesto varias veces por Bajtín en el desarrollo de su estudio: la posibilidad que se le otorga al autor de moverse dentro de un terreno (o lenguaje) que le permite tratar un argumento o un punto de vista no oficial sobre la materia en cuestión. En Castilla se está juntando gente para cierta guerra. Los personajes, grotescamente, exaltan las maravillas de sus lugares de proveniencia: la «Gran Castilla / Que si saca su quadrilla / no ay (...) quien se le acueste» (vv. 702-703), sólo «Sevilla puede sacar una hueste» (vv. 705-706), Bilbao «tiene mucho buen puerto» (v. 721) y «vus ete vus sabi bien / notre studi de París» (vv. 723-724), pero, al mismo tiempo cada una de estas imágenes elogiosas tiene su contracara. Así es que los personajes se refieren a «la merda para Lisboa» (v. 711), «el bordell de Valencia» (v. 716) y, «pel cul de Deu» (v. 715); degradando sus expresiones se burlan los unos de los otros. Los castellanos tienen cola, Cristo fue Portugués mientras que Judas viene de Córdoba. Naharro satiriza poniendo las virtudes nacionales en boca de personajes cuyo comportamiento moral es discutible, no obstante pretendan personificar las glorias patrias. Petiján exalta la superioridad intelectual francesa en un francés macarrónico. El personaje del Portugués aparece blasfemo, peleador, antisemita, y muestra desprecio hacia los españoles, que para él son marranos. Miguel está obsesionado por las instituciones conocidas de su ciudad. Fabio, el italiano, al fin, parece ser el primer hispanófobo italiano (Gillet, 1961, IV, 515) en la literatura en lengua castellana.

En el capítulo II de su estudio, Bajtín (2003, 171-172) se detiene en un episodio que, por la pluralidad lingüística, se asemeja al de Naharro. Nos referimos a cuando el joven Gargantúa, cansado de la curiosidad de la muchedumbre de París, comienza a inundarla de orina. Rabelais, en este caso, no describe la muchedumbre sino que refiere sus imprecaciones. Brinda, escribe Bajtín, un sorprendente cuadro dinámico de la plaza de entonces en su multiforme composición social y en su heterogeneidad lingüística: el guascón, el italiano, el alemán etc. Naharro, por su

\footnotetext{
${ }^{89}$ En los ejemplos mencionados por Bajtín generalmente el bufón personifica al rey que es golpeado y, por ende, destronizado.
} 
parte, parece hacer lo mismo evocando el ruidoso ambiente tinellero. Lo interesante que subraya Bajtín respecto de los juramentos de la multitud es que cada uno tiene «un matiz específico y suscita una especie de asociación suplementaria» (2003, 172); agrega, además, que es probable que nosotros no logremos captar las numerosas alusiones que, en cambio, resultaban claras para sus contemporáneos. Nos detenemos en algunos. Dice el portugués: «Ollai lá: / pois si Portogal querrá / armar ha suas caravelas / en cantas guerras avrá. / Ora andai e cagai nellas» (vv. 698-701). Según Gillet ${ }^{90}$ esta última expresión está precedida por un gesto que indica el objeto del verbo. Se trata de una interpretación plausible desde el punto de vista teatral, pero nos preguntamos si realmente el personaje se refiere a algún objeto cercano o a las mismas caravelas o si, simplemente, era una exclamación usual dirigida a los demás criados. «Dai cá, irmaons; / eu vos digo que marraons / son, de casta do diabo. / Naun brinquéis con castelaons. / Que trazen tan longo rabo» (vv. 737-741). Existe, al respecto, la leyenda de los hombres con cola cuyo origen y desarrollo Gillet analiza $^{91}$. «Cosa cierta / es aver luego rehierta / con quien va fuera de ley, / y con quien diz que a su puerta / cagó el cavallo del rey» (vv. 742-746). Proverbio que se burla de la ridícula presunción de la gente ${ }^{92}$.

Bajtín escribe que el Renacimiento es la única época, en la historia de las literaturas y de las lenguas europeas, que marca el final de la dualidad de las lenguas y el advenimento del «relevo» lingüístico. La barrera entre las dos culturas -la popular y la oficial- «pasaba directamente, en una de sus partes, por la línea divisoria de las dos lenguas: lengua vulgar y latín» (2003, 421). «Pero el problema no se limitaba solamente a las dos lenguas: la lengua nacional popular y el latín de la Edad Media; las fronteras de las otras lenguas presentaban también algunos puntos en común con esta frontera principal; la orientación recíproca de las lenguas era un fenómeno complejo y presentaba múltiples aspectos». El autor se detiene en la

\footnotetext{
${ }^{90}$ «The last words of this line (e cagai nellas) are probably preceded by a thigh-slapping gesture which sufficiently indicates the object of the verb. Cf. Sold. III, 87 ¡Para éstas! - ¡Cagá en ellas! Cf. Cal. IV, $460 \operatorname{cagar}(n) »$, (III, 1951, 478, n.59).

91 «Raboso, rabudo, cobarde (Tradición y semántica)», en NRFH, III (1949), 372-378.

92 «A proverb deriding ridiculous presumption, and current at the time in Italy as well as in Portugal» (III, 1951, 481, n.103). Gillet cita unos cuantos ejemplos.
} 
reflexión sobre una tercera lengua -el deseo de restituir al latín su antigua pureza clásica lo convierte ineluctablemente en una lengua muerta ${ }^{93}$ - como, asimismo, sobre la «orientación mutua» intensiva de los dialectos en el interior de las lenguas nacionales. Los dialectos se convierten en «una especie de imágenes integrales, de tipos consumados del lenguaje y del pensamiento, de máscaras lingüísticas» (425). $\mathrm{Y}$ es así que recuerda el conocido uso de los dialectos italianos en la comedia del arte como asimismo -algo que nos atañe- el uso típico medieval, con función cómica, de la lengua extranjera o inventada e inexistente. Las frases pronunciadas en lenguas desconocidas debían provocar la risa por su ininteligibilidad (425, nota 1). La actitud de Torres Naharro, como también la de los dramaturgos a él contemporáneos (Gil Vicente, Encina), frente a las lenguas extranjeras es familiar. Las encontramos en Serafina, con escenas en valenciano, italiano y latín y en Soldadesca con los personajes que hablan en italiano. Por otra parte, también vemos la presencia de la lengua española con fines paródicos en las comedias de autores italianos. Basta citar a Aretino.

Bajtín nos revela también el mismo proceso en la relación interdialectal dentro de la lengua nacional. «Si la orientación y la iluminación recíprocas de las grandes lenguas han agudizado y concentrado el sentido del tiempo y de las alternancias, la iluminación recíproca de los dialectos dentro de los límites de la lengua nacional ha agudizado y concentrado, en cambio, la sensación del espacio histórico, intensificando y dando un sentido al sentimiento de la originalidad local, regional y provincial. Se trata de un elemento capital en la nueva percepción diferenciada del espacio histórico de su país y de su mundo, característica de la época que se reflejó vivamente en la obra de Rabelais» (425). Este «relevo» lingüístico es

\footnotetext{
${ }^{93}$ «El renacimiento de la imagen de «renacimiento», pues su otra cara es la muerte. El renacimiento del latín de Cicerón transformó el latín en lengua muerta (...) El latín de Cicerón vino a iluminar el verdadero carácter del latín medieval, su verdadero rostro, que los hombres veían prácticamente por vez primera: hasta entonces habían poseído su lengua (latín medieval), sin poder observar su rostro deforme y limitado»(Bajtín, 2003, 422). «En este proceso de iluminación mutua de las lenguas, la época contemporánea viva representa todo lo nuevo, lo que no existía antes: las cosas, nociones y opiniones nuevas, logorando así una toma de conciencia de una agudeza realmente excepcional; las fronteras de los tiempos, las fronteras de las épocas, de las cosmovisiones y de lo cotidiano son palpadas de manera bastante precisa» (423).
} 
susceptible de ser aplicado también a nuestra comedia. Por otra parte, en sus estudios lingüísticos, Bajtín nos revelará también el plurilingüismo presente en toda sociedad.

Entran en la escena Escalco y los escuderos, Godoy, Moñiz y Osorio.

Si intentamos establecer una jerarquía tinellera, podemos individualizar tres grupos de personajes. Según la posición que cada uno de ellos ocupa distinguimos a: los oficiales, los escuderos y los criados. Los oficiales serían el Mastro, el Escalco, Barrabás y Mathías que se encargan de «administrar los gastos, comprar los víveres necesarios, preparar las mesas, tener a punto la comida, mantener la limpieza y salvaguarda de manteles y cubertería, velar, en fin, por el buen orden y funcionamiento del tinelo» (Teijeiro Fuentes, 1997, 134). A partir, naturalmente, de la posición que ocupan tienen mayor acceso a beneficios como, asimismo, mayor facilidad para llevar a cabo operaciones ilícitas. Los escuderos Moñiz, Osorio y Godoy representarían el segundo grupo. «Encargados de acompañar al Cardenal en los actos oficiales, su situación en el tinelo es muy incómoda y se quejan continuamente del mal trato que reciben y de las injusticias a las que se ven sometidos por sus superiores» (134). En fin, los criados que llevan a cabo los trabajos más humildes pero que no dejan de pensar en el propio provecho, como hacen todos los personajes de esta comedia.

Los escuderos entran en la escena adoptando, entre sí, un lenguaje formal. Se saludan con el tratamiento de 'vuestra merced' y 'cavalleros', tratamiento que teniendo en cuenta el lugar y la circunstancia en que se desarrolla-, parece adquirir un tono irónico. «Su ridículo sentido del honor choca con sus necesidades diarias, y si, por un lado, se quejan con indignación de sus superiores, a quienes acusan de traidores y cobardes a sus espaldas, por otro, procuran ganarse su amistad con el fin de lograr algún beneficio» (135). Godoy, sin distinguirse mucho de los demás personajes, entra en la escena muerto de sed y reclama, en vano, que le sirvan vino. 
Consecuente al mencionado tratamiento formal, Naharro pone en boca de Godoy una referencia al aspecto físico del escudero Moñiz: «iO, cómo venís polido! / Muéranse ora los barveros» le dice irónico (vv. 815-816). Los escuderos en sus conversaciones tratan los temas clave de la obra: «el mal trato que reciben, los deseos de ascenso social, las injusticias de que son víctimas, los delitos que se cometen sin el conocimiento del Cardenal, la falsa concepción del honor...» (135). Sin embargo, respecto a sus criados adoptan la misma actitud chantajista que sus superiores tienen con ellos. Lo vemos en el ejemplo de la riña entre Moñiz y Francisco (vv. 817-861) en la que el primero le pide al Escalco «Que a mi moço le matéis / y no le deis contumacia» (vv. 820-821) ${ }^{94}$. Este diálogo recuerda las peleas de Lazarillo con sus amos y es posible evidenciar en el mismo un rasgo picaresco. Naharro pone de manifiesto la explotación sistemática del criado por parte de Moñiz que trata de gratificarlo con alguna prenda gastada «¿Qué hezistes? / ¿Unas calças que me distes? /¡Por mi fe, frescas y bellas! / Dos reales, y aun bien tristes, me dio un judío por ellas» (vv. 852-856).

Sigue el diálogo entre Godoy y Moñiz en el que vuelve a manifestarse el mismo malestar de la jornada anterior: mal vino y mala comida «dan pan que sepa al molino, / la carne hiede un poquito, / y el agito dan por vino/ y el vino dan por agito» (vv. 893-896). Critican al traidor Mastro de casa, sus engaños, robos, presunción y soberbia. Quieren transmitir estas críticas al Cardenal para que éste remedie la situación y lo despida, a pesar de la indiferencia que suele mostrar. En este mundo de engaños y de turbia escalada social, Moñiz se cuida bien de estar siempre en buena relación con sus superiores, aunque deba tolerar abusos, porque, de este modo, se asegura una carrera sin obstáculos. El Mastro de casa es el oficial principal y Moñiz ha sido sorprendido por Godoy haciéndole reverencias humillantes; relevante es su preocupación por congraciarse.

\footnotetext{
${ }^{94}$ Dar contumacia: «Frase familiar, con que se explica que a algún convidado le dejaron sin comer, no queriendo aguardarle, porque tardó en venir a la hora regular: lo que se suele usar con frecuencia en las Universidades entre los Estudiantes, que están alojados a patio», en DA.

«En caso de contumacia el amo debiera pagar por la comida del criado en otra parte» (Zimic, 1977, 142)
} 
Al diálogo entre Godoy y Moñiz se suma Osorio. Hablan de voces que circulan y, en particular, las referidas a la impotencia de Osorio. Godoy menciona a su Madalena como autora de una de esas voces «Pero sabed que se suena,/ y aun se afirma reziamente,/ que la vuestra Madalena/ dize que sois impotente» (vv. 983-986). El diálogo grotesco es previsible y asume lineamientos casi esquemáticos. A la acusación sigue la réplica jactanciosa de Osorio «Sí, por Dios/ ya me ruegan más de dos,/ las cuales puedo mostraros» (vv. 987-989) y la contrarréplica de Moñiz sobre las mujeres que lo estafan «Callad, peccador de vos, / que éssas andan por pelaros» (vv. 990-991); «que la pensión que vendistes / se la comió Catalnilla» (vv. 10001001). El consejo que le dan los otros dos escuderos a Osorio es que sería mejor que se ocupara de servir a monseñor y no andar «al rabo de putas». La conversación, que denota algunos estereotipos en el pensamiento masculino sobre la mujer, deriva, en su lineamiento casi esquemático, al tema de las mujeres. «Es muger dulce veneno, / quando es mala mayormente, / y es como el fuego en el seno / y en la halda la serpiente», (vv. 1013-1016). Se refieren también a Salomón, David y Sansón que por culpa de las mujeres se cautivaron y tuvieron lo mismo que Osorio.

Godoy cambia bruscamente de conversación y se entra al reiterado tema del intercambio de beneficios «Mudemos otra cuestión:/ ¿vuestra cosa es expedida ?» (vv. 1038-1039). Godoy manifiesta que hay que rogar que Juan Vincle ${ }^{95}$ no la encuentre. De esta expedición depende el ascenso social. Se comprende que Osorio está solicitando un beneficio. En la conversación hablan del, ya mencionado, Monseñor del Bacano ${ }^{96}$ a quien un astrólogo judío le ha asegurado que será Papa; si

\footnotetext{
${ }^{95}$ Escribe Gillet (III, 403) «Osorio's supplicación (I. 398) was evidently a request for a benefice. At that time one of the prominent men greatly interested in benefices was a German named Johann Winkler, a notary of the Rota under Leo the Tenth, later referendario under the austere Dutch Pope Adrian VI».

«Johan Winkler, notario bajo León X, que acumulaba beneficios eclesiásticos en su persona. Parece que Osorio ha pedido un beneficio. La reserva que se cita más abajo se refiere a cierta clase de beneficio que no se concedía sin bula» (D.W. Mc Pheeters 1979, 135, nota 21).

${ }^{96}$ Ya en el capítulo IV de la Tercera parte, hemos mencionado la tesis de Gillet, quien supone que el nombre aludido se refiera a Giulio de' Medici, sin descartar que pueda tratarse, quizás, también del Cardenal Carvajal. A partir de Menéndez Pelayo, algunos críticos sospechan que el tinello del Cardenal romano no era otro que el de Carvajal; otros, en cambio, suponen que la referencia tenga que ver con Del Río, Medici o Suriano. De estas diferentes interpretaciones, se pueden ver las dificultades que encuentra la crítica en identificar a las personas con los personajes y los espacios en los cuales se
} 
el escudero lo seguirá, podrá tener un confesionario. Naharro transmite a través de los escuderos lo que es una aspiración y una práctica general: el que todos piensen en el proprio ascenso en la escala social y eclesiástica. $\mathrm{Y}$ es a través del comercio de favores que se obtienen los títulos y los beneficios, así como se da y se obtiene la comida en el tinello. No deja de ser absurdo, impertinente, pero al mismo tiempo cómico-grotesco, que un futuro Papa crea en predicciones que contrarían el mismo Cristianismo. La pretensión del Cardenal del Bacano es ilusoria y delirante -lo cual agranda la comicidad de la escena- ya que los propios escuderos mencionan a León $\mathrm{X}$, ungido Papa en 1513, de quien se dice que vivirá mucho tiempo y quien, justamente en ese momento está asistiendo a la representación de la comedia. Naharro satiriza en este fragmento no sólo las pretensiones del escudero, sino también la corrupción de valores que connotan el poder de la jerarquía eclesiástica

La jornada se cierra con la borrachera de unos veinte tinelleros reunidos en la cámara del Coco a los que se suman los escuderos.

\section{Jornada Tercera}

\section{El banquete entre bendiciones y maldiciones.}

Durante toda esta jornada se desarrolla una comida, con una delimitación rigurosa de las jerarquías. Las dos mesas -la de los escuderos, por una parte, y la de los criados, por otra- constituyen dos mundos diferentes, unidos, sin embargo, por el mismo tipo de quejas. No sólo el desarrollo de la jornada consiste en la comida, sino que el tema fundamental de las conversaciones es la comida misma, en una interrelación o superposición permanente entre cuanto está sucediendo y cuanto se está hablando.

desarrolla la comedia. Por otra parte, si la obra fue representada en el palacio Medici, este dato apenas da pie para colegir que el cardenal del Bacano sea el propio Medici; vale lo mismo con respecto a Carvajal y las otras personas posibles. Conviene recordar, asimismo, que en el Introito aparece el cardenal de san Jano, llegado de Egipto, quien también es identificado con Medici o con Carvajal, respectivamente (ver Aliprandini y Zimic, 192-201) y quiere llegar al trono pontificio. 
El primer motivo de esta jornada es el de la bendición. Quien debe hacerla, el capellán, no está, obstáculo que no arredra a los comensales y, por el contrario parece convenirles «que ora, por gratia de Dios, /no avrá ningún capellán» (vv. 1117-1118). Godoy, confesándose «medio sacristán», se ofrece para hacerla y «será mejor que ninguna» (v. 1125), porque la bendición, en boca de Godoy va acompañada de la maldición. Si, por una parte bendice «al que todos adoramos, / porque nos guarde de mal, / y al que nos da que comamos, / qu'es el señor Cardenal» (vv. 1127-1130), por la otra, maldice a los «traidores officiales»: «al Cozinero / que da la menestra flaca» (1137-1138) , «al Despensero, /que compra mula por vaca» (vv. 1139-1140), al Canavario que les da «ruin vino» (v. 1141) y al Escalco que les «sangra el ordinario» (v. 1145 $)^{97}$. A la maldición sigue la imprecación a Dios -que produce un efecto cómico- para que les mande sus favores, les preste sus orejas pero, también, los «libre de traidores, / lites y putas viejas».

A continuación se introduce un motivo iconográfico-diplomático, el lugar que cada cual debe ocupar en el convite. El tema de la discusión gira en torno a quién debe ocupar la cabecera, privilegio que, en la práctica protocolar, sólo es tal cuando se ofrece. Por el contrario, en una animada acción dramática, los comensales se disputan, como en un codo a codo, el derecho a ocupar ese sitial. Estamos en presencia de una concepción distorsionada de las relaciones sociales pero que, al mismo tiempo, refleja también las ambiciones desmedidas. El tratamiento de este desajuste protocolar constituye, al mismo tiempo un expediente cómico.

Los lamentos sobre la mala comida ocupan toda la jornada: falta el vino y la menestra es flaca: «Apostar / qu'este caldo singular / es agua con yervezillas, / que era puesta a escalentar / para lavar escudillas» (vv. 1261-1265). Osorio quiere hablar con el Cardenal pero, como es difícil contar lo que pasa en el tinello -hecho consecuente con la astucia, que no esconde una cobardía- deciden escribirle una carta anónima, circunstancia ésta que aumenta la villanía. Los lamentos sobre la mala comida parecen una continuación de las quejas de la jornada precedente. Las

\footnotetext{
${ }^{97}$ Ordinario: «Se llama el gasto de cada día, que tiene qualquiera en su casa, y también lo que come regularmente y sin hacer exceso, ni tener demasía: y esta acepción se usa como sustantivo», en DA.
} 
acusaciones, las amenazas de delaciones y extorsiones se repiten a la llegada de dos palafreneros (los dos capellanes anunciados por Mathía al comienzo de la jornada. v. 1119), que quieren entrar a tomar unas copas -reivindican ser bien recibidos adonde vayan- y son rechazados por el Escalco. Ellos lo amenazan con contarle al Cardenal cómo roba. El Decano, por su parte, acusa al Escalco de ser tacaño, quien, a su vez, «¿Quién oyó / y en quál tinelo se vio / tractar mal nigún villano / a un Escalco como yo/ del Cardenal de Bacano?» (vv. 1371-1375), amenaza con denunciarlo al Cardenal.

En la mesa de los criados, se reitera una conversación multilingüística, en la cual el vizcaíno pide una porción para su amo que le es rechazada. Estalla una pelea alrededor del Tudesco que trata de esconder un pedazo de carne en la manga, pero que se le cae debajo de la mesa, por lo que recibe dos meses de suspensión. Por su parte, el Tudesco indica al Catalán que ha robado un pedazo de pan y se hace pasible de la misma punición. En este último caso, la delación toma el lugar de la posible complicidad o solidaridad entre los criados, de lo cual se deduce la ausencia de un código de clase y sí la presencia -podríamos decir amoral- de una constante que es el engaño, casi sistemático.

En la mesa de los escuderos, el tema reiterativo es el de la comida y el vino. El compartir una manzana da motivo a una crítica explícita -que ya estaba implícita en la misma acción- a lo malo que han comido. Aparece un indicio sobre la autoridad que da la posición; así, Moñiz critica a Escalco, que ha ganado en presunción desde que ha cambiado la pelleja, al que le hace coro Godoy «Aquí se haze un león / en la calle es un oveja» (vv. 1469-1470).

Llega el Mastro de casa y apuestan a que los va a mandar a cabalgar para acompañar a la puta suya que ha muerto ese día. Efectivamente van a cabalgar, pero al bautismo del embajador de Guinea, pagano que se ha convertido al Cristianismo. Al igual que en la escena en la que el hecho de acceder a la cabecera de la mesa, como privilegio que se ofrece, se trastoca en una disputa grosera por el lugar, del mismo modo la escena del cortejo por el embajador se convierte en la representación de una farsa, con tintes y dimensiones carnavalescas. El efecto cómico es evidente: 
¿qué impresión podía producir una procesión llevada a cabo por semejantes individuos para nada cristianos e inmorales acompañando al guineo pagano que realmente quiere convertirse a la religión cristiana? Se trata de una escena deliberadamente grotesca. Al referirse a la misma, Zimic $^{98}$ dice que recuerda a Quevedo y a las pinturas negras de Goya $(1977,166)$.

Más adelante, en diálogo entre el Escalco y Godoy se plantea una situación interesante que toca el problema de la separación de roles, que asume una dimensión ética, por un lado, política por otro. El Escalco comunica a los escuderos que Monseñor le ha dicho que todos deben hacer la guardia que les toca, bajo pena de que quien peca por vez primera no come por un mes, quien insiste será licenciado. El lamento de Godoy en el sentido de que el Escalco obra con arbitrariedad al dejar fuera de su lista «más de dos», encuentra como respuesta que debe ocuparse de sus cosas y no de las demás. Se acusan mutuamente, hasta el momento en que el Escalco manifiesta que brinda sus favores a Godoy en calidad de amigo, lo cual tiene como respuesta que el hecho de ser amigos, no priva al escudero del derecho de criticar su gestión de la casa, «mas no impide la amistad / que el hombre diga lo que siente. / Vos sabéis que la igualdad / la loan Dios y la gente» (vs. 1552-1555). Es éste uno de los diálogos, exentos de comicidad, en el que emerge una nota, diríamos, didáctica, concorde, quizás con los principios que Naharro compartía.

En la jornada que nos ocupa, Godoy alude varias veces, de un modo severo a la condición de pobreza en que se encuentran los escuderos. Esta circunstancia lleva a Zimic a opinar que, si nos proponemos encontrar algún retrato de Naharro en esta comedia, el fiel de la balanza se inclina más por Godoy que por el Escalco (1977, 154). Conviene recordar que, de algún modo, el escudero forma parte de un estrato social, parte de cuyos intereses se identifica, en realidad, con los de los sirvientes, mientras que sus aspiraciones van por el lado de los oficiales.

\footnotetext{
${ }^{98}$ «La pregunta de Godoy es apropiadamente sugestiva: «pues, ¿quién lo bautizará?» (p.235). En la mente del escudero hay justificadas dudas de que en Roma se hallen individuos espiritualmente calificados para ello. El lector debe ahora representarse en la imaginación la procesión en honra del embajador que va a realizarse por la tarde: ¡el guineo pagano y hondamente deseoso de converstirse a la religión cristiana, rodeado del concurso pomposo pero cínico, materialista, inmoral, malintencionado, descreído y, en suma, nada cristiano!(...)»
} 
Las miserias narradas por Godoy inician un recorrido de críticas similar al que desarrolla el sirviente Rosso de la Cortigiana de Aretino, el Prudencio del Diálogo y discurso de la vida de Corte de Castillejo, etc. (Gillet, 1961, 513). Gillet piensa que la comedia va más allá de la descripción de una jornada típica de la vida en el tinello del Cardenal y en las habitaciones privadas de los oficiales. Se trata de una descripción objetiva de los hechos, un realismo puro que linda con el naturalismo. Gillet se pregunta si las comedias Soldatesca y Tinellaria, sobre todo la segunda, no podrían ser verdaderos estudios sociales; sólo con un toque de positivismo las haría tales en el siglo XIX. Nadie mejor que Naharro, según el mismo Gillet, desarrolla una comedia de la sociedad políglota reunida en Roma (513-514).

Es de notar, por lo que se refiere a la estructura, que la bendición, acompañada de la maldición están en el comienzo y en el final de la comida. No ha aparecido ningún capellán y Moñiz, como antes Godoy, se encarga de la ceremonia, que adquiere características cínicas. Comienza bendiciendo al jolgorio en torno a Campo de Flor y a la desidia con que piensan en servir al Cardenal, como, asimismo a la Navidad por la «torta tan ancha», y maldiciendo al oficial «porque demanda la mancha» (v. 1595). Esta estructura se repite hasta el final; a cada bendición sigue una maldición: «bendigo a Mastre Bramante / que a Sant Pedro començó, / maldigo aquella vacante / que aquel traidor me llevó» (vv. 1602-1605). La referencia a Bramante, el noto arquitecto que dirigió la construcción de la basílica de San Pedro a comienzos del s. XVI, como asimismo la mención a Pasquín «En fin fin, / bendigo a Mastre Pasquín / que se aparta deste afán, / maldigo solo el quatrín / que en mi bolsa hallarán» (vv. 1606-1610) son ulteriores pinceladas de actualidad que Naharro nos ofrece ${ }^{99}$.

\footnotetext{
${ }^{99}$ Las «pasquinate», una de las tantas formas de expresión de la literatura popular, eran escritos satíricos anónimos, generalmente contra los papas, que se colocaban sobre una estatua fragmentaria llamada Pasquino que se encontraba al costado del Palacio Orsini, hoy Palacio Braschi, en Roma. Citamos algunos ejemplos de pasquinate: por la muerte de Alejandro VI «Qui giace Alessandro sesto. È sepolto con lui / quanto venerò: il lusso, la discordia, l'inganno, / la violenza, il delitto»; por la muerte de León X «Gli ultimi istanti per Leon venuti, / egli non poté avere i sacramenti. / Perdio, li aveva venduti!». Otros ejemplos: «Vuoi farti ricco e rendermi tue gentillezze accette? Dammi pei miei sollazzi fanciulli e verginette»; o Marforio y Pasquino, las dos estatuas hablantes de Roma dialogan: «Come vanno gli affari? Benissimo Marforio, commandano i giullari».
} 
En el Diálogo del Nascimiento, Naharro se había ocupado de indicar los abusos más destacados de las prácticas religiosas. En la última escena de la Addición del Diálogo pone también en evidencia la dicotomía entre lo que debería ser la palabra de la oración y en lo que realmente se transforma. Recuerda la bendición de esta jornada pero, asimismo, nos remite al personaje del arcediano de la jornada quinta no admitido, como veremos, al banquete final de los tinelleros. «La religión practicada sólo exteriormente es, en efecto, nada menos que una parodia de la religión» (Zimic, 1976, 72-73). Estos personajes, religiosos desobedientes, representan en la obra de Naharro un «microcosmos siempre reconocible», según Zimic, que, en realidad, más que micro era macro.

Sin embargo, es de notar, el tono con el cual Moñiz cierra su bendición en la que se vislumbra una cierta autenticidad de sentimientos y que contrasta con el final de la bendición de Godoy.

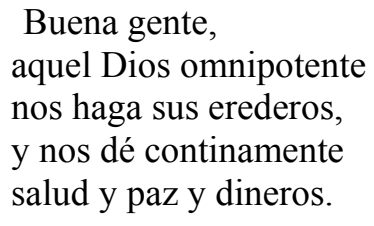

Se van «a ver a dos pares de moças» (v. 1620).

\section{Jornada Quarta}

«De sobremesa»

El despensero se lamenta de los pocos beneficios que ha obtenido en su vida. Anhela un dinero que, por contraposición -según su lógica simple- nada significa para la hacienda del Cardenal. Se proponen, junto con el Mastro de casa, escapar «hermanamente» después de haber robado, pero nos encontramos, otra vez, con la acusaciones recíprocas y la lógica de los engaños picarescos. De la misma índole es el 
diálogo que sigue entre el Mastro y Osorio, que no quiere compartir el cuarto, también aquí con reprensiones recíprocas, tretas, amenazas, y atribuciones de culpabilidad. Hay, sin embargo, algunas referencias de orden didáctico-moral, como éstas en boca de Osorio: «Do se ataja/ que quien sin orden trabaja,/ sus afanes poco duran,/ y con el tiempo y la paja/ los peruétanos maduran» (vv. 1775-1779).

La novedad de esta jornada es la aparición del personaje de Manchado, comparado por Gillet con Juan Gonçález y Pero Pardo en Soldadesca, llegado de Castilla en busca de beneficios. «G: Mas codicio / que me digáis quál indicio / vos hizo venir a Roma. / M: Vengo por un beneficio / que me dé que vista y coma» (vv.1970-1974). El personaje recuerda a Betiseo del Diálogo del nascimiento que llega a Roma con el único propósito de ver reliquias y comprar indulgencias. Ambos personajes presentan un carácter ingenuo y credulón, como aprendices apenas de las astucias y estratagemas del arribismo social. «M: El Papa diz que los da [los beneficios] / a todos quantos los quieren. / G: Con favor / havréis en Campo de Flor / un par de canonicatos. / M: Miafé, no vengo, señor, / a buscar canes ni gatos» (vv. 1978-1984). En tren de comparar, es interesante subrayar cuanto dice Zimic con respecto a «cierta dueña» que Betiseo encontró en Francia y que le habló de las reliquias de Roma. Naharro, según Zimic, sugiere «la estrecha relación entre la superstición de las reliquias y los chismes, las consejas de viejas, desautorizando simultánea y satíricamente ambas cosas» $(1976,51)$. El diálogo sigue de la siguiente manera:

\begin{tabular}{ll} 
GODOY & $\begin{array}{l}\text { Con razón. } \\
\text { Queriendo, Papa León } \\
\text { vos puede sacar de mal, } \\
\text { y aun con un sancto bastón } \\
\text { hazeros un cardenal. } \\
\text { Gran prazer. }\end{array}$ \\
MANCHADO & $\begin{array}{l}\text { ¿Y no lo sabrías ser? } \\
\text { MOÑIZ }\end{array}$ \\
MANCHADO & $\begin{array}{l}\text { A la fe que resabría. } \\
\text { GODOY }\end{array}$ \\
¿De qué manera? \\
MONCHADO & \multicolumn{1}{c}{ En comer } \\
más de diez vezes al día. \\
& $\begin{array}{l}\text { Por tu vida, } \\
\text { ¿qué sería tu comida? }\end{array}$
\end{tabular}


MANCHADO Mucha carne con mostaza

y a cada pascua frolida

una gorda gallinaza.

Zimic subraya el siguiente fragmento del Diálogo: «Señor, no dudéis / que muchas más cosas en Roma veréis / iglesias devotas, de grandes perdones, / y todos los días del mundo podéis / a vuestro plazer ganar estaciones» ( 1976, 54). «Patrispano [el otro personaje del diálogo] obviamente conoce muy bien el poder imaginativo de los promotores romanos del turismo. Iglesias devotas de grandes perdones es una expresión de felicísima ironía, por lo gráfico con que se refiere a la supuesta parcialidad de Dios y los santos con respecto a varias iglesias. Todos los días del mundo - nótese la hipérbole - a vuestro plazer, son asimismo, versos muy tersos y sucintos, llenos de significado satírico: abundancia de comodidad comercial que uno compra en cualquier momento a su antojo. De una disposición espiritual apropiada para dirigirse a Dios ni una palabra» $(1976,54)$. Esta visión de Roma se asemeja a la actitud también de Manchado.

\section{Jornada Quinta}

\section{Bacanal}

Es el momento de la fiesta, al anochecer, cuando los oficiales se preparan de nuevo a comer.

La jornada se abre con el ya mencionado lamento del Escalco sobre su condición de pobreza. «Yo soy el más desdichado / que jamás vino de España (...). Toda mi vida sirviendo / y pobre ansí como ansí, / paresce que van huyendo / los beneficios de mí» (1994, 399, vv.2077-2083. Estos versos han sido motivo de divergencia de opiniones entre los críticos. En varios puntos de su estudio Zimic $(1977,127,177-182,202)$ ha refutado la interpretación de Gillet y Bataillon que ven en el Escalco un autorretrato del autor. Sin detenernos mayormente en este aspecto ya tratado, nos centramos en una frase importante que escribe Gillet respecto de la última escena de Tinellaria: "Also de roistering slaves of the Stichus may have suggested the final scene of the Tinellaria, wich makes the reader think of the more 
elaborate "Propos des bien yvres" in Rabelais' Gargantua» (1961, IV, 516). La referencia a Rabelais quizás no es casual y el desenlace festivo final nos hace retomar, una vez más, a Bajtín. El Escalco y Mathía renuevan la discusión, ya presente en la Celestina y también en la comedia Himenea sobre si los sirvientes deben esperar o exigir -verbos que explicitan dos actitudes diferentes y contrapuestas frente a la realidad- los premios debidos. Uno de los sirvientes aparece con una buena selección de vino. La comida promete bien. Se prepara el banquete. Las imágenes de los convites, - del comer y del beber-, con su fuerte tendencia a la abundancia y a la universalidad - «su hiperbolismo positivo, su tono triunfal y alegre» (Bajtín, 2003, 250)- determinan la formulización misma de las imágenes. Muchas de las caracteríticas del banquete, citadas por Bajtín, se encuentran en la obra de Naharro y, en algunos casos, adquieren el mismo significado. Los personajes en esta última jornada beben, comen, cantan y bailan compulsivamente. Notemos que el Arcediano, que ha perdido la reputación, y Retama no son admitidos y que, con cierta ironía, es mencionado Agustín Guis ${ }^{100}$, famoso banquero de Roma calificado de pobrecito. La situación es un naufragio en la oscuridad. Esta escena remeda paródicamente a las grandes catástrofes épicas. No se pueden parar y con los brazos hacen como si fueran lanzas y tratan de apagar una vela. Algunos están en el piso, otros hacen movimientos de natación, tratan de alzarse para juntarse con los otros. El naufragio y la oscuridad, aquí, nos remiten a aquel sistema de imágenes que, como dice Bajtín lleva a «una nueva compresión de la verdad», in vino veritas, «el vino libera de la piedad y del temor. «La verdad en el vino» es una verdad libre y sin temor» (257) que permite un encuentro triunfal y alegre con el mundo.

Aquí recordamos un aspecto ya mencionado en páginas anteriores, que se refiere a la vinculación, puesta en evidencia por Bajtín, entre el banquete y la sátira. Las imágenes del banquete, en algunos casos, revisten una tendencia estrictamente satírica y, por lo tanto, negativa; sin embargo, las mismas imágenes, en cuanto tales, mantienen su naturaleza positiva. Esta tendencia negativa no pervierte la materia

\footnotetext{
${ }^{100}$ Agostino Chigi. El tercer soneto de Naharro escrito en italiano aparece dirigido a un figliolo del rico Augustino, según Menéndez Pelayo (1941, 299), y se trasluce que es poesía mendicante.
} 
misma de las imágenes, que asume una relevancia positiva. En este sentido, repetimos, las imágenes con una finalidad satírica continúan viviendo su propria vida en el convite. No se agotan en la tendencia a la cual sirven, ni se esclavizan a la misma. Consideramos que es éste el sentido y la perspectiva con los que debemos leer e interpretar las imágenes cómico-grotescas en la comedia Tinellaria. Si bien los personajes revisten características extremamente negativas -glotonería, envidia, lujuria, mentira, etc- , las imágenes que utiliza el autor para mostrar los vicios y aberraciones de los tinelleros conservan la misma fuerza positiva de la que habla Bajtín. Desde este punto de vista, la comedia muestra una fuerte carga satírica mediante la cual se denuncia la corrupción eclesiástica y las variadas formas en que la misma se manifiesta en la práctica religiosa.

\subsection{La especificidad de la comedia Jacinta}

J.P.W. Crawford sostiene que la comedia Jacinta fue compuesta para celebrar la visita de Isabella d'Este a Roma, hipótesis que, más tarde, harán suya también otros críticos ${ }^{101}$. «The Jacinta may be dated among the earliest plays of Torres Naharro, that is, in 1514 or 1515, probably after the Comedia Trofea and before the

\footnotetext{
${ }^{101}$ Gillet, acepta dicha hipótesis aunque no con total certeza (1951, III, 602). Otis Green, en cambio, sostiene con convicción la propuesta de Crawford (en Gillet, 1961, IV, 524). Oleza, a partir del dato «si recitò una certa Farsetta alla spagnola, qui hebbe assai dil galante, durò circa hora e meza»- que aparece en una carta escrita por Isabella d'Este, desde Nápoles, a Bernardo Capiluppo, escribe: «¿Quién pudo ser el autor de esta "farsetta alla spagnola", que no era rústica sino "galante", y cuya duración excedía con mucho a las de las farsas españolas del Renacimiento? (...) A la Jacinta le convienen la ocasión (el homenaje a Isabella d'Este), las posibilidades del autor (pues bien pudo estar en Nápoles quien unos días antes estaba en Roma), el estilo "alla spagnola" (por sus múltiples referencias a temas hispanos, como el de la persecución de los judíos), la condición de "assai galante" (el leve argumento es una excusa cortés para rendir homenaje a una dama) y hasta la duración (apropiada a la más corta de las comedias de Naharro, con sólo 1307 versos). Aún así se trata de una mera especulación, y no es muy seguro que una espectadora tan culta y tan amante del teatro -aunque al mismo tiempo tan frívola- como Isabella d'Este llamara "farsa" o "farsetta" a una pieza que se presentaba dividida en cinco jornadas, por mucho que en el Argumento el rústico la bautizara como "breve comedieta". Sea como fuere, lo que parece indudable es que Torres Naharro escribió la Jacinta en homenaje a Isabella d'Este con ocasión de su viaje de 1514-15» $(2004,234)$.
} 
Tinellaria» $(1937,76)$. La estadía de la marquesa revistió el carácter de un verdadero fasto, pleno de extravagancia y espectacularidad ${ }^{102}$, como lo testimonian los documentos de la época. La comedia cuyo argumento «parece más propio de los cuentos maravillosos o los relatos de caballerías que del teatro en sí» (Teijeiro Fuentes, 1997, 121) narra de una dama, Divina, que exhorta a los transeúntes por sus tierras a detenerse y a contarle sus desventuras: «Una dama muy loçana, / de gran vertud y nobreza, / tenía una fortaleza / d'un camino muy cercana. / Poníase a la ventana / muchas vezes a prazer, / con voluntad y con gana / de nuevas nuevas saber» (vv. 85-92). Naharro ofrece un cúmulo de reflexiones, podemos decir casi de carácter universal, en el que confluyen temáticas atinentes a la relación entre el amo y su servidor, la amistad y la vida en general. Los personajes Jacinto, Precioso y Fenicio expondrán sus quejas, respectivamente, en las jornadas primera, segunda y tercera, mientras que Divina -que para algunos críticos se identifica con la misma Isabella d'Este- aparecerá en la jornada V. Una caracterización precisa nos brinda el autor sobre los caminantes: «Todos tres van sospirando / sin prazer y sin dinero, / cada qual por sí quexando, / quexosos muy por entero, / de señores el primero / y de amigos el segundo / y el otro de todo el mundo, / qu'es el tercer compañero» (vv. 101-108).

Esta comedia ha sido objeto de las más diversificadas interpretaciones por parte de los críticos. S. Gilman (1963-64) es quien más se arriesga en su lectura al fundar su hipótesis a partir de la idea lanzada por Castro ${ }^{103}$ e identificar en los personajes de la comedia a un cristiano viejo, Jacinto, «abandonado por su amo», a

\footnotetext{
${ }^{102}$ Marin Sanudo en sus Diarii cuenta la festosidad que acompañó su estadía y la atención que le brindaron el Papa y los cardenales. La marquesa había asistido, lo citamos como ejemplo de ostentación y magnificiencia, a una cacería ofrecida en su honor por el Papa, en la que se movilizaron 3.000 caballos y en que se capturaron 50 ciervos y 20 jabalíes (Marín Sanudo, XIX, 391, cit en J. Oleza, 2004, 1).

${ }^{103}$ Hemos ya mencionado que Américo Castro toma en consideración la posibilidad de que Naharro fuese un converso. El crítico deja abierto el camino a esta interpretación en La realidad histórica (México, 1962, 185). Ver nota 49 de este trabajo de investigación.

Cabe recordar que Roma representa una atracción para los eclesiásticos literatos españoles - como lo es Naharro - y, en particular, para aquellos de origen judío. Esta comunidad ocupa un lugar importante en la ciudad y la aceptación que demuestran los papas hacia ella es grande, circunstancia que favorece la difusión de la cultura y literatura hispánica - teniendo también en cuenta que buena parte de la literatura castellana de la época estaba escrita por conversos de origen judío.
} 
un converso, Precioso, «más o menos sincero, atormentado por amigos y vecinos», a un marrano errante, Fenicio, y a un morisco, -el servidor de Divina-, Pagano. Gilman no rechaza el reconocimiento de Isabella d'Este en Divina, aunque como él mismo escribe, «en otro nivel de significación», puede tratarse de Roma misma «acogiendo en sus brazos abiertos a todos los refugiados que huyen del fanatismo periférico» (36). Roma representa el lugar en el que encuentran protección, «en ese abrazo verdaderamente católico» los conversos de toda especie. Zimic (1977) decididamente desecha esta suposición y rebate punto por punto las argumentaciones de Gilman. Se trata -para Zimic, y en contraposición con las suposiciones de otros críticos- de la última pieza teatral incorporada por Torres Naharro en Propalladia «porque parece revelar que a pesar de todos los terribles males que Torres Naharro vio y padeció en su vida y que dramatizó en las comedias anteriores, no abandonó por eso su optimismo y su esperanza con respecto al género humano» $(1977,306)$.

Hemos decidido detenernos en la lectura parcial de esta comedia por dos motivos fundamentalmente: el primero, se refiere a la fuerza con que se impone el rústico del introito de Jacinta, «mucho más ignorante, enrevesado y ridículo que los personajes análogos de Lucas Fernández y Juan del Encina» (Gilman, 1963-64, 20); el segundo, porque a través de sus personajes el autor introduce el tema de la crítica al estilo de vida licencioso dominante en las cortes romanas y que analizaremos en los apartados siguientes. El juicio de Naharro se demostrará más severo en las piezas por nosotros comentadas que en la presente comedia.

Los introitos, como lo hemos dicho en el capítulo II, eran recitados por un rústico que, a través de sus burlas, se proponía familiarizar con el público para introducirlo, así, en la ficción dramática. Este rústico, profundamente arraigado en la tradición carnavalesca respecto del lenguaje en el que se expresa y las imágenes que nos brinda, es singularmente grosero y casi obsceno. «Rebentado muera yo, / como la burra dell otro, / si lugo no m’aquestotro / como entre gentes estó. / ¡La puta que me parió! / Porque no me acuerdo ya... / mas cro que sí ... nantes no. / Ea, bovo, harracá» (vv. 1-8). La lengua rústica en la que se expresa resulta ser mucho más marcada que la del introito de la comedia Soldadesca. Gillet restaura el «puta que me 
parió» atenuado en las ediciones tardías del s. XVI y XVII (1951, III, 587, nota al verso 5). El personaje, en su performance cómica, se detiene en cuestiones de descendencia familiar -«Noramala acá nascí / hi de neja, pan perdido, / que solía, hendo assí... / atronar todo 'll exido, / Una grita y un croxido, / y en la mitá del invierno, qu'el diabro del enfierno / cuido que estava esmarrido (vv. 29-36)- para pasar luego a la descripción de algunos juegos populares que caracterizan la festiva ambientación villana. Dice el rústico:

Ver a las mil maravillas los juegos que allí s'armavan: unos que nunca callavan, otros a dar conbadillas, correnderas las bovillas todas ellas, juri a nos; al toro, las correndillas, y al salto d'espera en Dios, vos comigo, yo con vos, que no quedava nenguno, quando apárate con uno, quando apárate con dos. Oras a hurta el capote, oras a daca el ovillo, oras asconde ' 11 orillo, oras a dile más diote, oras a hinca el picote 65 oras a passa morato, y a la chueca y al garrote, $\mathrm{y}$ al tejo y a guarda el hato.

Es conocida la importancia que adquieren los juegos en la cultura cómico popular, contextualizados en el ambiente específico de la fiesta. «Los juegos de todo tipo (desde las cartas hasta los deportivos), las predicciones, adivinaciones y augurios de toda clase, ocupaban un lugar preponderante en la expresión popular y pública de la fiesta» (Bajtín, 2003, 207). El vocabulario que ofrecían era amplio y, a partir de los mismos, se extraían metáforas y comparaciones, a menudo también alusivas. Naharro menciona aquí varios juegos: entre ellos, combadillas, por ejemplo, que consistía en 
dar volteretas, la chueca ${ }^{104}$, en cambio, era una especie de jockey practicado por rústicos, etc. Escribe Gillet que «The speaker happens to remember an amazing number of country games, a recital of which must have brought to the audience a powerful suggestion of amorous dalliance on the green, of freedom an joy» (1961, IV, 521). Gilman, por su parte, opina en cambio que «la crudeza del Introito y la infame genealogía del personaje que lo recita contrastan vivamente con la presentación apacible y cuasi-bucólica de los conversos que aparecerán más tarde» (1963-64, 20-21).

Notamos que la comicidad, como lo indica Noël Salomon (1985) se encuentra en estrecha relación con la contigüidad espacial en la que se realiza la representación. Nos referimos al desajuste cultural entre personaje y espacio, desajuste que, por lo demás, se presenta como uno de los atributos fundamentales de lo cómico; en nuestro caso, el hecho de situar a un pastor burdo e irreverente en la corte. El efecto cómico existe desde el momento en que el contexto se convierte en inadecuado para el personaje. La forma típica utilizada para provocar la risa frente a un público culto es, por lo tanto, la de «echar a unos villanos palurdos, con pesadas almadreñas, en medio de un elegante auditorio de salón» (60). En linea general, en las piezas de Naharro, la figura del pastor inculto y grosero se manifiesta en los introitos; sin embargo, cabe recordar que, en la comedia Trofea (jornada II), recordada en las páginas de Bomarzo (Mujica Lainez, 1967) y en el Diálogo del Nacimiento, el personaje rústico se incorpora a la acción principal de las obras mismas.

El pastor de Jacinta concluye su introito con las siguientes palabras «A la mi fe yo's presento / una breve comedieta» (vv.81-82); la palabra «comedieta» denota, de alguna manera, el carácter ligero que Torres Naharro quizo darle a este texto.

El primero que entra en la escena es el personaje de Jacinto que procura «huir / desta vida y de su nombre, / pues un pobre gentil hombre / no puede en ella vibir. /

\footnotetext{
${ }^{104}$ Se entendía un tipo de «diversión que se desarrolla posicionándose los participantes en dos grupos, uno enfrente de otro, procurando cada uno que una bolita pequeña (la chueca en cuestión), empujada por los contrarios con unos palos de punta combada, no pase de una raya o meta». Se encuentra documentado con anterioridad en la Égloga de Plácida y Victoriano de Juan del Encina y en las farsas de Lucas Fernández, entre otros lugares. (Di Pasterna, 2003, 245)
} 
Porqu'están oy, sin mentir, / de maldad lo pueblos llenos, / y vemos por bien servir / de lo más venir a menos» (vv. 169-176). Se lamenta ampliamente del mal trato que los señores tienen con sus criados - que estiman a «los traidores por discretos/ y los buenos por grosseros» (191-192)- y de la forma indigna en que los usan. En un crescendo siempre más intenso, Jacinto ataca a los «tiranos traidores» (v. 217) que tienen en sus manos el poder y que, sin vergüenza, se aprovechan de los «agenos sudores»; llega hasta poner en tela de juicio a la misma ciudad de Roma «qu'es lo peor, / siendo la tierra mejor / de lo poblado del mundo» (vv. 238-240). Jacinto «al hablar del mal del mundo, (...) destaca especialmente a la Ciudad eterna, como centro de iniquidad» (Zimic, 1977, 228). Más adelante, en la jornada V, el personaje de Precioso, que procede de Roma, pondrá el acento en los vicios que conciernen al Papa y en los abusos que los ricos ejercen sobre los pobres, siempre en busca de beneficios. «En Roma los sin señor / son almas que van en pena, / no se haze cosa buena / sin dineros y favor» (vv. 1057-1060). Los personajes se indignan frente a la corrupción e injusticia en la ciudad, aunque lo hacen de una manera, casi genérica. Se trata, efectivamente, de una sátira/denuncia aparentemente blanda con respecto a la que encontramos en la misma Sátira o en el Capítulo III; sin embargo, según Zimic, es importante notar que «no se trata de una diferencia de intensidad satírica, sino tan sólo de la manera de expresarla» $(1977,232)$. El personaje dirá, inclusive que «Dos cosas no pueden ser / de plazeres y dolores / ni peores ni mejores, / que son Roma y la muger» (vv. 1065-1068): seres paradójicos, según Gilman, «a la vez divinos e infernales» $(1963-64,37)$ que, por lo tanto, pueden ser identificables en un mismo sujeto dentro de la comedia. Roma es, para el crítico, a la vez corrompida y entregada a las prácticas paganas pero también «capital de la armonía y del placer» (38). Cuesta creer que Naharro haya querido dar una imagen confortable y salvadora de la ciudad pontificia. Creemos, junto con Zimic, que todo lo que se dice en la comedia sobre Roma es negativo mientras que la mujer es presentada con tonos superlativos. Nos referimos, aquí, al diálogo de la jornada IV, entre los tres peregrinos, en el que muestran sumo respeto, gratitud y admiración hacia el sexo femenino. 
Hemos leído los versos de la comedia Jacinta sobre Roma como una preparación / preámbulo a la lectura de los apartados siguientes en que emerge explícitamente la sátira aguda de Torres Naharro.

\subsection{Escritos satíricos}

Roma se convierte, en la Sátira y en el Capítulo III, en un objeto literario con función crítica. En el primer texto el autor enfoca el tratamiento del tema romano a partir de una visión amplia, casi universal; en el segundo, en cambio, a partir de su experiencia personal - «Yo he hablado / según he visto y palpado» (vv. 120-121). En el Concilio de los Galanes y cortesanas de Roma, invocado por Cupido, sólo tangencialmente, la ciudad en sí es objeto temático. El autor, más bien, centra su atención en la corte papal y en su lascivia.

Naharro ofrece una imagen tajante de la corrupción de la corte pontificia y de sus costumbres. Podemos decir que se trata de textos complementarios de las comedias, cuyo contenido remite al degrado espiritual y moral en el que se encuentra la Iglesia. La literatura cómica de la Edad Media encuentra su apoteosis, -escribe Bajtín- durante el apogeo del Renacimiento, en el Elogio de la Locura de Erasmo, una de las creaciones más eminentes del humor carnevalesco en la literatura mundial (Bjtín, 2003, 19). Los textos satíricos de Naharro comparten el mismo mundo de ideas de Erasmo: «podemos afirmar sin vacilación que en este escritor no falta ninguna de las posturas fundamentales de lo que conocemos como erasmismo. Lo repetimos: crítica de la corrupción eclesiástica, de las formas externas de la religión y una simultánea exaltación del sentimiento religioso interno, inspirado en la vida ejemplar de Cristo. Aspiración a unas relaciones más humanas caracterizadas por la sencillez, probidad, caridad y justicia. Éstas se determinan precisamente por el recto sentir religioso, según Torres Naharro. Podemos comprender más claramente que ésta es la verdadera postura del autor si recordamos que 'El erasmismo se alimentó de restricciones más que de afirmaciones'» (Zimic, 1976, 93). 


\subsubsection{La Sátira}

La Sátira es uno de los primeros poemas, tras las Lamentaciones, que inaugura Propalladia. El autor se propone ofrecer una visión de la Roma contemporánea partiendo del «esquema mítico de las edades de la humanidad, como queda claro por las alusiones al reino de Cronos que abren el poema, con elementos tomados de la Genealogia deorum de Boccacio (VIII, 1) al hacer la aretología del dios» (Escobar, Montero, 2005, 390).

Aquel que sus hijos está deshaziendo y ansí se los come después de creados su hos en la mano, los hombros cargados, los ojos sumidos y el gesto arrugado; tan lleno de canas, tan mal figurado, la barva salida, los dientes caídos, perdida la vista, también los oídos, cargado de días y suelto de pies.

Aquel viejo ruin si digo quien es:

del Cielo y de Vesta segundo eredero $(\ldots)^{105}$

Gillet, opina que el personaje de Saturno-Chronos personifica toda la corrupción de Roma ${ }^{106}$, Zimic, por el contrario, considera que Saturno personifica a un individuo determinado y que éste sería Julio II. «La ingeniosidad de Torres Naharro consiste precisamente en identificar el canibalismo feroz de Saturno con el del Papa, sugiriendo además varios otros aspectos horripilantes» $(1976,29)$. Saturno devora a sus propios hijos y a Julio II, también, se lo acusa del mismo pecado. Se le imputa, además, de ser el anticristo mismo, de haberse rebelado contra Cristo y San

\footnotetext{
${ }^{105}$ «Llama poderosamente la atención en ese texto [la Sátira] la elección métrica: el verso de arte mayor se despliega en la novedosa forma de pareados (salvo el verso inicial, que queda suelto). La solemnidad del viejo metro se reviste así de una andadura de poesía sentenciosa y gnómica» (Escobar/ Montero, 2005, 390).

${ }^{106}$ «This picture of Saturn-Chronos, to whose evil planetary influence, the poet here traces the whole moral corruption of Rome, with perhaps a veiled side-glance at the Renaissance Pope, or so, at least some people believed... can be understood as an expression of the medieval quality of Torres Naharro's imagination...» (Gillet, 1943, I, 66-67).
} 
Pedro y de haber causado catástrofes en toda Europa, «su gloria es el mundo, su Dios el dinero: / tras éste envegecen los hombres en Roma» (vv. 73-74) escribe Naharro.

Erasmo condena en muchas de sus obras -Dulce bellum inexpertis, El elogio de la locura - la conducta inmoral del Papa. En Julius exclusus, obra escrita y publicada después de la muerte de Julio II, critica y satiriza los abusos del pontífice. En las cartas que Erasmo escribe durante su viaje por Italia (1506-1508) muestra adversidad hacia el Papa soldado y combatiente, y expresa horror frente a las devastaciones de las guerras e indignación hacia el Papa y sus triunfos, que se asemejan más a aquellos de Pompeo y César y no a los de Pedro.

El personaje de la Sátira corresponde en muchos aspectos a la figura Julio II (Zimic, 1976, 31-32) ${ }^{107}$ : «Su hoz en la mano» (v. 3); «Del Cielo y de Vesta segundo eredero» (v.10); «y a quien subiectaron por orden grossero / los años y meses, semanas y días, / las oras y puntos, por todas las vías» (vv. 11-13); «Cargado de días y suelto de pies» (v. 8). Toda la Sátira critica al Papa y la condición inmoral en la que se halla la humanidad. Naharro alterna con el tono general, descriptivo e impersonal, un «yo» (acompañado de un «y muchos otros») marcadamente presente y defraudado, «bivimos ascuras, / huyendo virtudes, seguiendo locuras, / loando lo malo, tachando lo bueno, / lisonja en la lengua, maldad en el seno. / Las cosas más feas traemos en palmas; / triunphan los cuerpos, mas iguay de las almas!» (vv. 20-25). Este juego de alternancias le permite crear imágenes que impactan por la precisa contraposición que ofrecen entre lo que es malo y lo que es bueno, y reflejan la crítica y el lamento por la pérdida de los valores espirituales. «No ay hombre de nos que piense en el cielo, / ni quien haga caso del siglo futuro: / el mal va por bien, el ayre por muro, / lo negro por blanco, lo turbio por claro, / virtud por estiércol, maldad por reparo, / lo sucio por

\footnotetext{
${ }^{107}$ Gillet supone también que se podría tratar de Alejandro VI. Al respecto Zimic escribe, «nos parece absurdo suponer que Torres Naharro pensara en un Papa muerto, cuando tanto tenía que decir del vivo, cuyo papado coincidía con su estancia en Roma» $(1976,33)$. Tampoco podía tratarse de León X, Papa estimado por Torres Naharro como también por Erasmo; Zimic también escribe en referencia a los retratos de Rafael de Julio II y de Ticiano de Alejandro VI: «Rafael, favorecido por Julio II, no dejó de sugerir el aspecto engañoso del carácter un tanto bonachón en el retrato que hizo del Papa. En efecto, varios rasgos fisionómicos en la descripción de la Sátira coinciden de manera interesante con ese retrato. Es cierto que también Alejandro VI, pintado por Ticiano, corresponde en muchos detalles al retrato en la Sátira», 1976, 33.
} 
limpio, lo torpe por bueno, / la ciencia por paja, doctrina por heno, / justicia en olvido, razón desterrada» (vv. 95-102). Asistimos a lo que algunos críticos llaman «inversión de los valores» ${ }^{108}$ y que, una vez más -aunque con una visión distintaremiten a Bajtín. En el caso de Zimic y Villanueva la «inversión de los valores» responde, más bien, al querer marcar claramente la conducta inmoral del Papa. Desde lo alto de su función, el pontífice debería ser un ejemplo moral para sus fieles, virtud que no posee. «Lo más interesante de la estructura de este poema es su carácter circular. El ejemplo que da el Papa con su conducta inmoral llega al último rincón de la sociedad y la mala semilla empieza, como es natural, a germinar» (Zimic, 1976, 35). Digamos que Zimic le atribuye un carácter moral, con función casi didáctica, al uso que Naharro hace de las imágenes opuestas.

«Y huyen d'un sancto gran predicador / y siguen de grado tras un hechizero» (vv. 71-72). En estos versos, Torres Naharro alude a Savonarola y el «hechizero» resultaría ser Julio II. También Erasmo menciona la hechicería de este Papa en el Julius exclusus.

Roma aparece mencionada en el verso 74 cuando la crítica adquiere un carácter más específico en contra de aquellos que aspiran a conseguir beneficios y dignidades eclesiásticas. Podemos decir que, en la visión del autor, la degradación de la ciudad es el reflejo de la degradación del mundo «y, al mismo tiempo, el síntoma e incluso su causa» (Escobar, Montero, 2005, 392). Se retoma así la idea ya expuesta por Naharro a través del personaje de Jacinto cuando decía «Practican más mal que fundo / y en Roma, qu'es lo peor, / siendo la tierra mejor / de lo poblado del mundo» (vv. 237-240).

\footnotetext{
${ }^{108}$ Zimic retoma el análisis llevado a cabo por Francisco Márquez Villanueva quien en su estudio Espiritualidad y literatura en el siglo XVI (Madrid, Alfaguara, 1968) menciona esta inversión de los valores, no sólo en la Sátira sino también en otros autores de la época. Escribe Villanueva «...Fue Erasmo quien la consideró uno de los argumentos decisivos para condenar la maldad de los tiempos, pues dicha inversión de valores en la inmediata vecindad de los príncipes, que debieran de dar el ejemplo contrario, se instala después en todos los niveles sociales y llega a pervertirlo todo» (p.84, cit. en Zimic, 1976, 35, nota 27).
} 


\subsubsection{El Capítulo III}

Este Capitulo ofrece una mirada bien concreta hacia la ciudad y encarna la verdadera sátira antirromana en la poesía de Torres Naharro (Gillet, 1961, IV, 419). El poeta, a partir de su experiencia en la ciudad, rechaza las opiniones comunes y corriente sobre la misma; por ejemplo: «Roma caput mundi» o « communis patria», «Roma que los locos doma» ${ }^{109}$ etc. Escribe Naharro: «Otros» la llaman «cabeça del mundo» (v. 22), en cambio, «yo cabeça de inmundicia» (v.23). Y para definirla, entre otras expresiones, utiliza también «castillo de malicia» (v. 20), «cueva de pecadores» (v. 40) «purgatorio de bondad / infierno de caridad / paraíso de luxuria» (vv. 69-71).

Así Roma, para Naharro, no es una «communis patria, / mas común padrastro, sí» (vv. 28-29). Lugar de perdición en el que encuentran refugio los más grandes pecadores: una escuela «de peccar / do quien bive sin matar / paresce que haze harto» (vv. 51-53). En Roma quien miente gana el perdón, hacer bien es una traición y robar es el pan bendito. «Un mercado do se vende / lo que nunca tuvo precio» (vv. 94-95). «Basta que en Roma, a mi ver, / no queda mal por hazer / ni bien que venga en efecto» (vv. 111-113); «digo que Roma es lugar / do para el cuerpo ganar / havéis de perder el alma» (vv. 129-131). Con una fuerte intención crítica y moralizante Naharro desenmascara el ambiente que caracteriza la ciudad. A través de una ironía, que adquiere tonos en algunos momentos polémicos («Si alegáis / que en ella os abilitáis / para en corte o fuera della, / son maldades que amparáis / o con que al mundo sirváis, no bondad maldita aquella» vv.132-137) Naharro retoma (o reflexiona contemporáneamente) el discurso llevado a cabo por Erasmo, cuyo fundamento es la renovación radical de la conciencia cristiana mediante el retorno a las fuentes del Cristianismo, a una religiosidad interior, más allá de la Iglesia, de sus ritos, del clero y de sus instituciones.

\footnotetext{
${ }^{109}$ Gillet investiga en el capítulo III (57-58; 64) de su Propalladia el origen de estas expresiones tan comunes.
} 
El autor lamenta la proliferación de epitafios dentro y fuera de las iglesias y hace una irónica mención de la compraventa de indulgencias «Hazen de Dios tal extima / que les passan por encima / a mil cuentos indulgencias» (vv. 86-89).

Recordemos que las sátiras contra la ciudad eran tan comunes entonces como también en el pasado clásico y medieval. Conocidas son las fórmulas de «Roma meretrix» o su variante «Roma Babylonia». La voz de Naharro en el Capítulo y en la Sátira se suma, en la historia literaria, a la de aquellos autores que en muchas de sus obras censuraron las costumbres de la ciudad.

«Nuestra Roma un gran jardín / de muchas frutas poblado» (vv. 79-80) es, quizás, la expresión más blanda que utiliza el autor para pintar la ciudad eterna. Estos versos denotan la heterogeneidad de su composición y, de alguna manera, su ambivalencia. Si, por una parte, es manifiesta la crítica a las costumbres de Roma, por otra, debajo de la misma subyace el lamento, más insinuado y apenas explícito, de que las cosas sean así en una ciudad que debería ofrecer una contracara diferente.

\subsubsection{Concilio de los Galanes y cortesanas de Roma, invocado por Cupido}

El Concilio es también un poema satírico. Gillet supone que el mismo fue escrito en ocasión de la visita de León X a Boloña ${ }^{110}$. El motivo de la visita del Papa a esta ciudad es el encuentro con Francisco I, rey de Francia ${ }^{111}$. Zimic, en cambio, insiste en subrayar que se trata de las dos visitas que Julio II hizo a la misma ciudad. En el Julius exclusus Erasmo condena las empresas de este Papa contra Boloña y en el mismo Concilio trasluce el dato de que esta visita no había sido del todo pacífica.

\footnotetext{
${ }^{110}$ Least important, perhaps, as poetry... is the Concilio... of which a journey to Bologna with the Papal Court (December, 1515) was the occasion... is a part of the tradition of medieval burlesque, mingling religious and erotics elements...» (IV, 422).

${ }^{111}$ El motivo de esta visita del Papa a Boloña es el encuentro con Francisco I, rey de Francia que, aliándose con Venecia, había reconquistado el ducado de Milán, Parma y Piacenza, éstas dos últimas asignadas al estado pontificio tres años antes. León en aquella ocasión deja que Francisco I actúe, pero por otra parte, inicia tratativas secretas para regularizar definitivamente la cuestión religiosa en Francia. Un año después este acuerdo será uficializado en el quinto Concilio ecuménico de Letrán que León X cierra el 16 de marzo de 1517. Los históricos recuerdan este hecho como la única nota positiva del Concilio que,Julio II había convocado como respuesta a los cismáticos del Concilio de Pisa.
} 
Lo recuerda la presencia de dos mil soldados en la ciudad «Y si algunas deste pan / no dan tan buenos bocados, / en Bolonia hallarán / del modo que los querrán / dos mil gentiles soldados» (vv. 366-370). Por otra parte, la visita de León X sí había sido pacífica. El significado global del Concilio es que la corte Papal, corrupta, esté donde esté, todo lo transforma y embrutece.

En la breve introducción al poema, Torres Naharro expresa el deseo de establecer el orden en el «enamorado vivir» de los galanes y cortesanas de Roma dado que éste no tiene «ni ley ni orden»y entre las dos partes existen «continuas renzillas y espessos escándalos». Este restablecer el orden, irónicamente, tiene como objetivo que los sujetos puedan ejercer sus funciones con más provecho y eficacia, de ninguna manera que éstos hagan una revisión moral de sus actitudes poco ortodoxas. El poema se estructura en dos partes. En la primera, el alto Cupido, «dios y señor conoscido / de toda la gran libido / con las provincias de Amor» (vv. 3-4) propone «de hazer reformación / sobre la torpe Luxuria.» (vv. 9-10), es decir, reglamentar los vicios relacionados con la lujuria a través de la introducción de algunas leyes. «Tres son las cosas que en los hombres serán reformadas» ${ }^{112}$, «cuatro en las mugeres ${ }^{113}$. «La república ordenada del vicio, propuesta por Cupido, garantiza, y ésta es la intención principal de la reforma, un servicio más puntual y una ganancia mucho más segura» (Zimic, 1976, 59). Además Cupido «escúsase de reformar la sodomía» ${ }^{114}$ : en estos versos dedicados al vicio de sodomía (según el uso del término en la época), el mismo dios de la libido la condena pero, al mismo tiempo, se muestra incapaz de poder controlarla. Zimic ve aquí, de nuevo la alusión a Julio II.

El autor dedica algunos versos a lo que él subtitula «quién son los que han de dar y tomar», en «con quién harán (las damas) las caricias fingidas» y «con quién

\footnotetext{
112 «Por las damas contentar / será allí determinado / quién deve dar y tomar, / y quién las ha de pagar / y quién ha de ser pagado. / Sobr'este caso haremos / lo qu'es razón que se haga, / de modo que juzgaremos / y por ley aclararemos / cómo se entiende esta paga» (vv. 41-50).

113 «Por quitar daños y males / que causan muchas señoras, / nombraremos a las tales / con quién han de ser leales / y con quién serán traidoras; / y a las que caçan las vidas / con caricias lisonjeras, / pornemos leyes devidas / con quién usen las fingidas / y con quién las verdaderas» (vv. 51-60).

${ }_{114}$ «De la nefanda passión / qu'el infierno multiplica, su justa reformación / era tornar en carbón / al cuerpo que tal paltica; / mas nuestra pluma lo calla, / no cierto por covardía, / sino porque ya se halla / que quiso Dios reformalla / está peor cada día. Por tan ruin vicio se toma / y ansí Dios dél se querella, / que ya se teme de Roma / no haga el fin de Sodoma, / pues lleva el principio della;» (vv. 61-75).
} 
serán las caricias verdaderas». En la segunda parte del Concilio encontramos un Vando proclamado por Cupido en que invita a las damas a alcanzar a sus galanes en Boloña «las damas que, sin partidos, / puestas en gran cirimonia, / s'están en Roma en sus nidos, / porque los sus favoridos / mueran de hanbre en Bolonia» (vv. 331335). Se nota cierta dependencia entre los galanes y las damas. Ellas no pueden estar sin «obispo y escritores» y ellos, los favoridos no pueden estar sin ellas. Los favoridos, naturalmente son corruptos que «codician más de dos / con los dineros de Dios / enriquecer al diablo» (vv. 173-175) ${ }^{115}$.

Muchos son los intereses que las damas romanas pueden encontrar en Boloña ${ }^{116}$. A través de ellos Naharro denuncia, una vez más, el comportamiento licencioso de los cortesanos. Se trata de mostrar el espíritu orgiástico y sensual de la corte. Cuando la corte se corre de lugar lleva consigo sus males. La referencia al Coliseo ${ }^{117}$ adquiere un sentido simbólico, -el Papa se lleva consigo también el monumento que, entre otras cosas, representa el martirio de los cristianos. Zimic irónicamente subraya la inutilidad del esfuerzo de Gillet en buscar el indicio de un Coliseo en Boloña.

La estructura del poema ha sido pensada según los concilios papales verdaderos de aquella época. Cupido, dios de la libido, más que del amor, una vez más puede ser identificado con Julio II. No sabemos, en realidad, si se trata realmente de Cupido/Julio II o de Cupido/otro Papa. Lo claro y evidente es que la sátira está dirigida en contra de la Curia y esto es lo que nos interesa. Subrayamos las siguientes palabras del comienzo del Concilio, en que Cupido se introduce y que indican esta afinidad entre estructura conciliar y poema. Zimic utiliza el subrayado para identificar a Julio II y los concilios por él convocados. «Nos el muy alto Cupido / por el humano favor / Dios y Señor conoscido / de toda la gran libido / con las provincias

\footnotetext{
115 ¡Quán santos y quán benditos! / ¡Qué colorados y gordos! / Pero pobres infinitos / van tras ellos dando gritos, / y ellos haziéndose sordos. / Mas dexémoslos andar / pues que son de nuestro vando, / vosotras avéis de obrar / para que podáis gozar / lo que ellos ganan cantando.» (vv. 176-185).

116 «En Bolonia está la corte, / las rentas y el despender, / en Bolonia ay el deporte / los plazeres y el conorte, / que mayor no puede ser. / Y si vuestras devociones / os hazen en Roma estar, / en Bolonia ay estaciones, / indulgencias y perdones, / quantas quisierdes ganar» (vv. 371-380).

117 «No falta allí el Coliseo / y otras cosas de plazer / con que perdáis el deseo / de ver las galas y arreo / que en Roma se suelen ver» (vv. 381-385).
} 
de Amor; llamada congregación en nuestra raviosa Curia, quedamos en conclusión / de hazer reformación / sobre la torpe Luxuria, / Que se reforme mandamos / en Concilio general... » (vv. 1-12) «Fue fecha por mi mandado / y en Consistorio ordinario, signada...» (vv. 431-432).

Además se encuentra, en los versos iniciales del Vando a las sobredichas señoras, referencia a las bulas de Julio «Yo Cupido, Dios de amor, / que todo el mundo poseo, (...) mandando en Roma hazer / un pregón contra las tales. / Ansí que hago mandar (...)» (vv. 316-346).

Vale la pena recordar que nos encontramos en años de concilios ecuménicos. Por una parte, el Concilio cismático de Pisa $(1511)^{118}$, en el que se encuentra involucrado Bernardino Carvajal, el protector de Naharro, por la otra, el V Concilio de Letrán convocado por Papa Julio II (1512) en respuesta a la provocación de Pisa. León X cierra en 1517 este Concilio, última ocasión, según algunos históricos, para evitar la ruptura que poco después se daría en el mundo cristiano con Lutero. Una farsa, según algunos históricos, que no cambió de aspecto ni durante el pontificado de Julio II ni durante el pontificado de León X.

Que la figura del pontífice Julio II fuese moralmente dudosa es claro. Sin embargo, vale la pena también preguntarse si, realmente, León X ha sido una figura moralmente intachable, -citando también la opinión de Erasmo ${ }^{119}$ - e incorrupta. Muchos de los vicios que se le atribuyen a uno caracterizan también las actitudes del

\footnotetext{
${ }^{118}$ Los cardenales que acompañan a Carvajal en esta aventura son Borgia Francesco, Briçonnet, Sanseverino y René de Prie y con el sostén de Luis XII y Maximiliano. A los fines de la lectura de las sátiras de Naharro y de las interpretaciones de Zimic este hecho resulta significativo. Sobre todo porque algunos históricos escriben que Carvajal acepta, en aquella ocasión, el título de antipapa (Martín VI) en Milán, hacia donde se transfiere más tarde el Concilio. Julio II excomulga a los rebeldes y los depone de sus cargos. Carvajal escapa a Francia pero más tarde, durante el pontificado de León X renuncia formalmente al cisma y es restaurado en su cargo.

${ }^{119}$ Escribe Zimic $(1976,33)$ «Por otra parte, a León X, sucesor de Julio II, que además no se asemeja en absoluto al retrato, ni física ni moralmente (de la Sátira), Torres Naharro no tenía razones para satirizarlo». En la nota 26 (33) Zimic habla de los admiradores de León X entre los cuales se encuentra Erasmo que escribe en Dulce bellum inexpertis: «todos sus deseos, designios y empeños están dirigidos a unir en concordia a todos los que están unidos por la misma fe....». Recuerda que Naharro se refiere a León X siempre con cordialidad, mientras que el Papa en el privilegio de Propalladia llama al autor «dilectus filius». Para Zimic, estas palabras «son más sinceras y de tono más personal de lo que se suele pensar». Asimismo recuerda que fue estrecha la relación que Naharro tuvo con el primo del Papa Julio de' Medici, futuro Clemente VII. Remito a la nota 26 (33) que ofrece información exhaustiva.
} 
otro. Como hemos dicho al comienzo, algunos críticos suponen que Torres Naharro se escuentra en Roma a partir de 1508 bajo la protección del cardenal Bernardino Carvajal. Si aceptamos esta posibilidad, es posible que Naharro se inspirara, para escribir sus sátiras, en las ideas reformadoras que circulaban en torno a Carvajal. El Concilio de Pisa fue una tentativa fallida de reformar la Iglesia. Y en tal caso resulta plausible que el blanco de las sátiras de Naharro es, como supone Zimic, Julio II.

En estos escritos satíricos, como hemos visto, Naharro nos presenta elementos, informaciones, situaciones que, de uno u otro modo, son desarrollados de manera similar, más orgánica y sistemática, en las comedias, de las cuales pueden ser considerados complementarios.

\section{Un excursus necesario: el Diálogo del Nacimiento}

En el curso de este trabajo de investigación hemos apenas mencionado el Diálogo del Nacimiento, pieza dramática de contenido religioso en la que se exalta la festividad del nacimiento de Cristo y que es considerada una de las primeras escritas por el autor ${ }^{120}$. El argumento que caracteriza esta obra apenas roza la centralidad del tema que nos ocupa aunque en ella encontramos algunos elementos generadores que serán determinantes en lo que hemos denominado «composiciones romanas». Nos referimos aquí a la presencia de la sátira antirromana que se vislumbra en sus versos y a la de los rústicos en el desarrollo principal de la acción, circunstancias que explican la oportunidad de este excursus.

\footnotetext{
${ }^{120}$ La fecha de composición de la obra según M. Pelayo es 1512; Bataillon y Zimic sostienen la misma hipótesis. Gillet, en cambio, la considera más temprana, entre 1505-1507, escrita en el ambiente de ortodoxia religiosa española, antes de llegar a Roma. Según el crítico el introito y la Addición serían de época romana, circunstancia que Zimic contradice.
} 
Las referencias religiosas, la continua alusión a personajes bíblicos, los pasajes relacionados con sucesos de la historia sagrada, están tomados de las Escrituras y son la parte reflexiva de la obra. No se recuerda ningún ejemplo en la literatura española del Renacimiento, anterior a esta breve pieza, en el que se emplee el diálogo como instrumento intencionado de un intercambio de ideas y como medio de abogar por una postura filosófica (Zimic, 1976). La religiosidad que encontramos en el Diálogo coincide, para Zimic, con los principios éticos propugnados por Erasmo. Naharro recurre también a la alegoría, haciendo aparecer a personajes como Humildad, Prudencia y Virginidad, como elemento moralizador de la historia. Con la introducción de los pastores, en la Addición al Diálogo, se introduce, en cambio, el elemento cómico grotesco.

Dos peregrinos, de carácter muy distinto (Patrispano tiene una fe interior firme, Betiseo en cambio, concibe la religión como un negocio para enriquecerse), se encuentran, una noche, en un lugar indeterminado. Patrispano viene de Jerusalén, Betiseo -que se nos presenta indignado porque unos «ladrones cosarios» le han robado algo fundamental, la calabaza llena de vino, o «sangre de nuestro señor»-, en cambio, viene de Santiago de Compostela y se dirige hacia Roma para participar del sorprendente espectáculo, en todos los sentidos, que ofrece la ciudad. Una cierta «dueña» le ha contado «de tantas reliquias y cosas de ver, que en Roma vería, si pluguiese a Dios, / por do desta vez yo stoy por creer / que santos y buenos iremos los dos. / Contóme, por tanto / que entre otras reliquias y cosas d'espanto / vería las alas de Sant Gabriel / y un cierto jubón d'Espíritu Sancto, / y aun unas coraças de Sant Michael» (vv. 696-704), a lo que Patrispano responde, subrayando con amargura irónica el aspecto multifacético de la ciudad «Señor, no dudéis / que muchas más cosas en Roma veréis, / iglesias devotas, de grandes perdones, y todos los días del mundo podéis, / a vuestro plazer, ganar estaciones». «Patrispano conoce muy bien el poder imaginativo de los promotores romanos del turismo. Iglesias devotas de grandes perdones es una expresión de felicísima ironía, por lo gráfico con que se refiere a la supuesta parcialidad de Dios y los santos con respecto a las varias iglesias» (Zimic, 1976, 54). Betiseo, más adelante, agrega que quiere comprar un 
«confessionario» y que «Daquessos que entienden / me quiero informar a cómo se venden; / después otra cosa tras désta haré: / si quartos y ardites acá se despenden, / algún Agnus Dei tembién compraré» (vv. 715-719). Betiseo quiere ver reliquias y comprar indulgencias en Roma con la misma credulidad e inocencia que encontramos en el personaje de Manchado de la comedia Tinellaria. De alguna manera en sus palabras se anuncia el tema, que más tarde y en otras obras de Naharro se hará explícito, sobre la religión vivida de manera superficial y exteriormente.

Cuando Betiseo se refiere a la guerra, anticipa, de alguna manera, la actitud frívola de los mercenarios de Soldadesca, además de exaltar las victorias famosas de los ejércitos españoles con el mismo patriotismo con que lo hacen los sirvientes de Tinellaria en la escena políglota de la segunda jornada; asimismo, cuando se detiene en la posibilidad de acceder, en Roma, a algún beneficio eclesiástico, se asemeja en su comportamiento a los servidores de Tinellaria.

En el introito, el rústico se detiene en los pormenores de su matrimonio con una campesina. Los une, ante todo, una fuerte atracción sexual y, naturalmente, la dote. Impresiona en este introito, como en el de Jacinta, el lenguaje directo del personaje y la limpieza de las imágenes que ofrece: «Si acá te toviesse, la mano en las tetas quiça te metiesse, / y aquessa bocacha quiçá te bessasse, / y en éstas y en éstas, si no me mordiesse, / mi boca en su lengua gela recalcasse» (vv. 50-54).

La Addición del Diálogo comienza con la llegada de dos rústicos Herrando y Garrapata que desconocen por completo el mensaje divino y que viven todo lo que atañe al discurso religioso con extrema actitud cómica. Con ellos inicia la «degradación» bajtiniana de la conversación llevada a cabo hasta este punto por los peregrinos. El juego con las cosas sagradas se convierte en el punto clave de estos versos. Lo rústicos interpretan, por ejemplo, el nacimiento de Cristo a su manera y se preocupan por cuestiones como, por ejemplo, si el niño nació desnudo o con faldeta «H: que nasció Dios en faldetas. / P: No lo dudo. / B: No nasció sino desnudo / y como hombre, aunque era Dios» (vv.791-794). Dirigen preguntas absurdas a los peregrinos tratando de ponerlos en apuros y de descubrir su ingenio, como «¿por qué nasció en Bethlem?» (v. 823), «¿por qué nasció so el portal?» (v. 843), «¿ por qué lo 
parió su madre / nel pesebre naquel día, / sin partera, sin compadre / y sin otra compañía / con Josepe?», (vv. 848-852) etc.. Camino de la Misa del Gallo, además, imaginan las pullas y advertencias que harán al «abad», al «vicario», al «çaçardote», al «monazillo», al «beneficiado»y al «capellán», como, asimismo a los hombres y mujeres. Transcribimos estos versos porque nos resultan ejemplificadores de la burla a las figuras religiosas.

H: Yo'os lo aprisco, que sé pullas a barrisco, más de mil en una riça, para en dóminos bovisco y para el ju benediça.

G: ¡Hi del moro!

$\mathrm{Y}$ al peroña secoloro, ¿qué dirás, si lo dirán?

H: Que le salte encima un toro al puto del sacristán, y espetado se lo saque de pobrado, que no taña más campanas y que no coma bocado destas ochenta semanas.

$\mathrm{G}$ : $\mathrm{Y}$ al vicario, porque cunpra el trentanario, ¿qué le dirás quando canta?

H: Maldición de Santelario se le pegue a la garganta; nell ermita

le den todos una grita que muestre Dios gran mesterio; ranilla, sarna y moquita lo saquen d'o al cementerio.

G: Di, cogote, ¿qué dirás al çaçardote quando dirá el davangello?

$\mathrm{H}$ : Que con un gruesso garrote le çahundan el cabello; la corona, que se la roya una mona. las orejas los ratones y al rabo d'una atahona le saquen los compañones.

G: Di, carrillo, ¿qué dirás al monazillo 
quando va por el guisope?

H: Que lo tome Dios un grillo

qu'el diabro no lo tope,

tan chequito,

que si en casa diere un grito

que no lo oyan en la calle,

y lo sopren como a hito

1015

$\mathrm{y}$ apenas nadie lo halle.

G: ¿Qué as pensado

dezir al beneficiado

para el dóminos obisco?

H: Que allí donde está sentado

le salte un asno morisco, y roznando,

lo dexe muerto sudando

que no pueda resollar,

solo que de quando en quando

se esconda tras ell altar.

G: Pues, verás,

¿al capellán qué dirás

para el juva benediça?

H: Que le pongan por detrás

huego a la sobrepelliça;

y d'un cerro

l'assomen al rabo un perro,

y el mi burro lo bendiga

con sus quatro pies de hierro

y el pico de la barriga.

G: $\quad \mathrm{Y}$ a los hombres

¿qué dirás que los asombres

al dar en las mataduras?

$\mathrm{H}$ : Començaré por los nombres que quitan las callenturas:

Sant Andrés

los haga coxos de pies, y sordos, ciegos y mudos, y sus mugeres, después, los hagan grandes cornudos.

$\mathrm{G}$ : $\mathrm{Di}$, si quieres,

¿qué dirás a las mugeres después daquessotra gente?

H: Que se tomen sus prazeres comigo primeramente; y si essas tales se salgan por los corrales, huyendo de sus maridos, a topar con los zagales que estamos por los exidos. 
Los peregrinos durante esta conversación entre los pastores guardan silencio. La parodia final es el canto del Ave Maris Stella, entonado por Patrispano y seguido burlescamente por los otros compañeros de viaje.

P: Celorum via nobilis est Maria.

H, G: Celorum via nobilis est Maria.

P: Ave maris stella,

Dei mater alma atque semper virgo, felix celi porta.

H, G: Celorum via.

B: En fin, fin, cante el padre por latín, dexáme a mí por romance.

G: Puto sea y hi de ruin quien no acetare esse lance.

P: Celorum via nobilis est Maria.

H: Zagales bía, qu'en Nápoles es María.

P: Sumens illud ave.

$\mathrm{H}$ : Soncas como sabe.

P: Gabrielis ore.

H: La miel y el arrope.

P: Funda nos in pace.

$\mathrm{H}$ : Damos buena parte.

P: Mutans Eve nomen.

$\mathrm{H}$ : Mil huevos por hombre, celorum via.

P: Monstra te esse matrem.

$\mathrm{H}$ : Moscas que te maten.

P: Sumat per te preces.

H: Çúmante los peces.

P: Qui pro nobis natus.

$\mathrm{H}$ : Que perros y gatos.

P: Tullit esse tuus.

H: Royan huessos tuyos, celorum via.

P: Virgo singularis.

$\mathrm{H}$ : Vinos singulares

P: Inter omnes mitis. 
H: Entre hijos míos.

P: Nos culpis solutos.

H: Vayan para putos.

P: Mites fac et castos.

H: Essos abadazos,

celorum via.

En la Addición del Diálogo Torres Naharro, entonces, propone las «pullas» que la gente solía arrojar en ocasión de las fiestas de Navidad. Gillet reproduce documentos fehacientes sobre estas prácticas. Según Zimic, la presencia de estas escenas en los textos de Naharro no corresponde, simplemente, a una atracción hacia lo popular o folklorístico por parte del autor, sino más bien a un deseo de ilustrar «la pedantería, la grosería y la ignoracia humanas, ostentadas con entusiasmo y una cerrada convicción de que representan la más fiel y pura devoción a Cristo» (1976, 70). Zimic no piensa en ningún momento en algo tan evidente como es el lenguaje del realismo grotesco; donde toda la celebración se degrada a nivel de burla ambivalente. No es casual que el mismo Patrispano, diga al rústico «tan sabiamente has hablado / que merescías ser papa» (vv. 807-808). En el uso que hace Naharro de estas escenas aparece claramente el concepto de sniženje de Bajtín. Zimic habla de intención contrastiva en Naharro: paz, amor y fraternidad que caracterizan la Navidad, por una parte, y vulgaridad y «bajeza» de estas escenas, por la otra. Sin embargo no explicita su pensamiento a través de la interpretación bajtiniana que a nosotros nos resulta más adecuada. 


\section{Conclusiones}

Nuestro trabajo de investigación se inicia con la consideración, bastante difundida, de cierta lectura perspectivista del teatro del siglo XVI (en particular con respecto a Lope de Vega), que hasta época muy reciente ha impuesto sus propios parámetros de análisis, soslayando tanto el significado como la especificidad del teatro renacentista, y de manera muy particular imponiendo su interpretación del vocablo popular a partir de las interpretaciones que del mismo se hicieron en el análisis de la obra del mismo Lope.

A través del estudio de un fragmento particular -que es la dramaturgia de Torres Naharro- perteneciente al inmenso corpus que representa el teatro de comienzos del s. XVI, hemos tratado de ilustrar, entre otros aspectos, la ruptura con esta actitud perspectivista. Nuestra intención, como lo hemos mencionado en la introducción, se apoya en ilustrar esta ruptura a través de la aproximación de la teoría bajtiniana acerca de la cultura cómica popular a una específica dramaturgia del s. XVI. Como mencionamos en nuestro trabajo, la teoría del crítico ruso sobre la cultura cómica popular ha sido considerada en España sólo parcialmente, sobre todo en el análisis del teatro de comienzos del s.XVI, en particular para el estudio de los personajes rústicos; prácticamente no ha sido tomada en cuenta la totalidad del significado de su teoría acerca del carnaval que, a nuestro parecer, se encuentra no sólo en muchas de las obras de este período, y no circunscripto a un único personaje, sino también en las obras analizadas de nuestro autor y que ofrece una perspectiva absolutamente distinta sobre la interpretación de lo popular en este teatro.

Cabe aquí una breve digresión. Las críticas a las obras de Bajtín han sido numerosas y diversas. Las dificultades que surgen al abordar sus trabajos -que abarcan una producción de cincuenta años- están, en primer lugar, en cómo sistematizarlos o reunirlos en un único corpus, teniendo en cuenta que, además de su 
variedad, algunos se contradicen. Baste para ilustrar estas dificultades los períodos fenomenológico, sociológico, lingüístico e histórico literario, que Todorov le atribuye al estudioso ruso o las etiquetas de formalista, post-formalista, semiólogo, marxista, materialista, humanista, neokantiano que le han atribuido, sin excluir las discusiones en torno a la paternidad de algunos escritos atribuidos a miembros menores de su grupo, como podemos leer en la páginas de Amícola ([1997], 2001, 147-152). Hoy en día nos encontramos, con respecto a este estudioso, con una inmensa crítica de su obra, proveniente de distintas corrientes, y en particular con muchas objeciones a su teoría sobre lo carnavalesco, en las que no faltan también muchos cuestionamientos de base. En algunas lecturas, la inversión de los valores no es lo «otro» del sistema, sino una parte de éste; es la contracara de una misma moneda. La organización de la cultura considerada como instrumento de poder confirmaría esta posición. Algunos críticos hablan, también, de una perspectiva mitológica en Bajtín que exalta el concepto de la fiesta en la plaza pública; dicha perspectiva puede encontrar su explicación en su relación con el marxismo. Por su parte, Wellek recuerda que, al igual que las instituciones, los géneros son convenciones, desafíos a las formas, a la tradición estilística que, de ningún modo tienen que ver con una «esencia», que subsiste, cambia, se renueva y vive en la memoria objetiva. Este último autor juzga que las reificaciones a las que induce Bajtín pueden tener asidero sólo sobre la base de una teoría que cree en los universalia ante res, es decir lo contrario de lo que muchos, entre ellos el mismo Wellek, consideran como los universalia in rebus ([1991] 1995, 508).

Creemos que, a pesar de las diferentes críticas que se puedan formular a su teoría, lo fundamental en la interpretación de Bajtín es el haber individualizado el aspecto central que atañe a la cultura popular, es decir el mundo de imágenes del realismo grotesco y el aspecto central respecto a la intelección de la cultura popular, es decir, el lugar que ocupa la figura del letrado en cuanto «filtro», según el término introducido por Ginzburg. El letrado que interpreta y expresa valores de la cultura popular, por otra parte, no puede hacerlo desde una atalaya olímpica; él mismo, como creemos haberlo demostrado en la figura de Torres Naharro, es ya una convergencia 
de su tiempo y espacio, de los valores en que se ha formado y de aquellos que intenta transmitir. Su mediación -el término mismo es significativo- no sería posible sin una conciencia clara de los valores contiguos que lo tocan y lo involucran.

Como sucede también con muchos otros estudiosos, formulaciones y aspectos importantes de la teoría de Bajtín pasan a conformarse como una metodología, como instrumentos válidos para iluminar ciertos estudios. Pensamos, en este sentido, que dichas formulaciones y aspectos no han perdido ninguna vigencia. Así, nos parece fundamental, sobre todo para la índole de nuestro trabajo, por ejemplo, la idea de que, ante todo, los estudios literarios deben establecer un vínculo más estrecho con la historia de la cultura. Toda obra nace en la historia, y la aserción de Bajtín de que la literatura es parte inescindible de la cultura y que no puede ser comprendida fuera del contexto de toda la cultura de una determinada época, nos parece significativa. En esto el estudioso ruso es muy claro, también frente a algunas consideraciones o prejuicios marxistas que quieren hacer depender directamente el curso de la literatura de factores exclusivamente económico-sociales. Bajtín no excluye la importancia que estos factores adquieren en la conformación de la cultura como fenómeno total, pues considera que sólo a través de ésta y junto con ésta, los mismos pueden tener relación con la literatura ([1979] 1988, 342). El arte literario no puede prescindir de los factores histórico-sociológicos y fundamentalmente culturales; fuera de ellos es imposible la compresión auténtica del fenómeno artístico.

En nuestro trabajo nos hemos detenido en todos aquellos aspectos contextuales que enriquecen la comprensión de la obra de nuestro autor y que definen las contigüidades culturales a las que nos referimos en el título. Dado que toda obra nace en la historia, en el caso particular de Naharro, su experiencia en los ámbitos romanos, el clima cultural, las relaciones con personajes del poder papal, etc. son elementos que deciden en su poética programática y coadyuvan a explicar muchos aspectos. Estas contigüidades - conformadas por los diferentes contextos que inciden en la práctica social- abarcan por igual los aspectos diacrónicos y sincrónicos, e inclusive las relaciones de Torres Naharro y de su obra con la tradición, pero también con la intención y el destino de tal obra, en un plano temporal amplio, como, asimismo, con 
el presente que le ha tocado vivir al autor y donde se ha generado la obra, es decir con el espacio y el clima culturales del momento. En el caso particular de Naharro, este momento y este espacio constituyen una etapa crucial, de decadencia y, al mismo tiempo de discusiones y cambios, contigüidades a las cuales nuestro autor no podía sustraerse. Por otra parte, la misma tradición literaria comparte, necesariamente, un espacio contiguo con los nuevos lenguajes y reflexiones renacentistas. Como recordamos en el Capítulo II, en la historia del teatro español de los siglos XV y XVI, aparecen, como un problema para nada marginal, los límites de los géneros literarios. No siempre es fácil establecer cuándo los límites entran en una confusión no deliberada o cuándo se trata de una decisión del autor, ya sea para provocar una ruptura con la tradición, ya por una necesidad meramente expresiva. Esto, si nos referimos estrictamente al texto literario. Recordemos que todo texto dialogado se llamaba comedia. Pero la práctica del espectáculo abarcaba un abanico de celebraciones, liturgias, fiestas de las más diversas, etc. donde se entretejían las contigüidades propias de la vida y del espectáculo.

Burke hacía notar que la aspiración a la restauración del pasado clásico era para los artistas del Renacimiento, no tanto un proyecto deliberado cuanto, simplemente, un sueño. El desajuste entre tal aspiración y la realidad del medio cultural y social en que vivían los llevaba a confundir los términos; es decir mientras aspiraban al modelo de la Roma antigua, como el ideal más cercano, estaban, paradójicamente, próximos a lo que experimentaban como lo más lejano, «la edad del medio», como la llama Burke. Por más que rechazaran las creaciones y la filosofía de su tiempo, se habían formado con los elementos que les podía ofrecer la cultura tardomedieval, muchos de cuyos valores habían incorporado y obraban necesariamente como un horizonte semántico, que les impedía escapar a la fricción con su tiempo o evadirse totalmente de él. De poco podía servir que rechazaran el reciente pasado del arte «gótico», de la filosofía «escolástica, y de la latinidad 'bárbara'», ya que ellos se habían formado dentro de esta cultura tardo-medieval que aún les pertenecía en muchos aspectos (Burke, 1990, 30). La literatura nos brinda muchos ejemplos al respecto, y esto lo vemos claramente en el teatro. Las creaciones individuales del 
período imitan de cerca los modelos antiguos, pero el contexto social y cultural es muy distinto. El mismo Burke acuña el término de «híbridos» (31) culturales clásicos, en algunos casos, y cristianos en otros. Los hombres del Renacimiento eran cristianos, pues no podían pasar por alto la cultura en que se habían formado. Existen, en este sentido, espacios y tiempos culturales contiguos, que a menudo suponen una contaminación constante entre los elementos clásicos y cristianos en las obras de arte. En el caso del Renacimiento, la idea de una ruptura tajante con la Edad Media carece de sustentación. Resulta lícito concebir el Renacimiento como el resultado de un desarrollo gradual, donde las viejas concepciones tardo-medievales van cediendo espacio a otras nuevas que anhelan la impronta clásica. En este sentido, el Renacimiento no constituyó un hecho repentino, único, originado de una vez para siempre, sino un momento que requería una nueva expresión, sin abandonar la continuidad, por una parte y el compromiso y la conciliación entre las varias tradiciones.

En la época que nos ocupa, aparece gradualmente una nueva concepción del espectáculo y específicamente una nueva idea de teatro: la idea moderna de teatro y de espacio escénico. Y esta aparición no es gratuita ni ingenua y en la misma las contigüidades se dan en todas las direcciones. Cruciani considera que el teatro es expresión de la cultura en la que se engendra y que el mismo no nace de una mera especulación teatral, sino de un encuentro dialéctico, bastante complejo entre una ideaforma elaborada y las prácticas, y lo denomina teatro «epifito», que se integra en la cultura de la cual forma parte y que, al mismo tiempo, expresa, y que, agregamos nosotros, constituye él mismo una cultura. Por ello, Cruciani, cuyas ideas compartimos plenamente, puede deducir que la historia del teatro del Renacimiento, no consiste tanto en la reconstrucción cuanto en la complejidad cultural, de la cual el mismo es «coagulo e portatore» y decir, al mismo tiempo, que las formas de representación son múltiples y no sistematizadas ni institucionalizadas. Los oficios del teatro no existen como tales, sino en función de procedimientos expresivos más amplios y de organismos de producción distintos entre sí (Cruciani, 1983, 7). Para estudiar el teatro de comienzos del s. XVI, y en particular el teatro italiano en cuyo 
contexto obra Naharro, nos pareció necesario, por lo tanto, tener en cuenta que el mismo es parte integrante activa y el resultado dialéctico de la rica y polifacética cultura del espectáculo construida en la época, tal como lo tratamos en el Capítulo IV.

En nuestra Introducción, dedicamos espacio a la problemática que se refiere a las relaciones entre la cultura popular y la cultura oficial, (ejemplificamos con esta oposición, pero son varias las denominaciones que han tratado de aclarar la cuestión); problemática que hemos ido ilustrando y aclarando en el curso de nuestro trabajo. Ambas comparten espacios contiguos. Los estudios de Bajtín revelan que el papel desempeñado por los hombres de cultura en esta contigüidad ha sido considerable.

La Roma en la cual vivió Naharro era una ciudad multicultural, teñida de internacionalismo, en la que confluían la cultura católica y la impronta de la Antigüedad. A partir de la mitad del siglo $X V$, se convierte, en una ciudad internacional por su estructura social y en supranacional por los numerosos intelectuales, provenientes también de otros países, como Juan del Encina, Gil Vicente, Torres Naharro, etc., que encuentran allí acogida y ocasiones de trabajo (Cruciani, 47). En este sentido, como escribimos en el Capítulo IV, la cultura que encuentra su expresión en la fiesta (o en el teatro) representa la cada vez más compleja composición social y cultural de la ciudad y constituye un espacio donde convergen los multifacéticos aspectos y comportamientos de la sociedad. Y en esta Roma no es casual que las lenguas linden constantemente, así como aparece claramente en las comedias de Naharro. Podemos hablar de una sociedad compuesta de hombres pertenecientes a otras culturas que interactúan y que comparten un mismo mundo.

«Le cose grandi» e «le cose vane» de las que nos habla Macchiavelli, en una carta del 1515 a Vettori, aluden a la coexistencia de aspectos que pueden resultar aparentemente contrarios. Lo cómico y lo trágico, para el autor del Príncipe, ocupan un mismo nivel de significación en la vida del hombre. En su escritura no existe oposición entre aspectos que podemos colocar dentro de lo ligero, inconstante, frívolo o vano, y aquello que estimamos serio, honesto y propio de los hombres «graves» como él mismo lo define. Escribe Macchiavelli: «perché noi imitiamo la natura che è varia e chi imita quella non può essere ripreso» $(1961,374)$. La concepción que nos 
ofrece presenta la idea de coexistencia, de alternancia entre los extremos, de circulación y contigüidad entre lo «alto» y lo «bajo», entre lo «serio» y lo «cómico» al fin. $\mathrm{Y}$ este pasar de las cosas vanas a las cosas grandes adquiere el valor de un movimiento vital, esencial a la entera medida del hombre.

Hemos encontrado en la figura de literato de Torres Naharro y en su misma obra literaria (que hemos analizado) la expresión de un arte que conjuga todos los elementos -o contigüidades- de que venimos hablando y que determinan la especificidad, no sólo de su teatro (y aquí, adrede, utilizamos una expresión genérica; bien sabemos que la misma abarca el texto dramático y espectacular y todas las contiguidades que lo conforman), sino también de un período. Podemos afirmar que Naharro comparte un mismo mundo de imágenes teatrales y culturales de clara presencia también en toda Europa, con códigos y prácticas reconocibles como tales, que se encuentran todavía lejos de aquellos que conformarán el teatro posterior.

Contrariamente a la tradición crítica que había individualizado en el texto dramático español, desde sus orígenes, características que lo separaban de la dramaturgia europea y que le conferían una identidad prevalentemente popular frente a la mayor proyección de otros teatros europeos, creemos haber señalado, a través del estudio de las comedias «a noticia» de Torres Naharro, que las mismas comparten un espacio de contigüidad con la creación dramática europea de su tiempo y son superadoras de aquellas concepciones que ven la esquemática disyuntiva entre los opuestos que hemos tratado en nuestro trabajo.

En la demostración de nuestra hipótesis, la elección de un autor como Torres Naharro nos ha parecido emblemática, no sólo en cuanto ilustración y ejemplo del eje de nuestro estudio, sino también porque su propia experiencia y obra constituyen un punto de partida para la comprensión de los primeros pasos en la escena moderna europea. 


\section{Bibliografía}

\section{Ediciones}

Aliprandini de, L., (ed.), Comedia Tinellaria, Bologna, Arnaldo Forni Editore, 1985.

Cañete, M., Menéndez Pelayo, M., (eds.), Propaladia, Madrid, Libros de Antaño de la Librería de los Bibliófilos (IX-X), 1880-1900.

Gillet, J.E., (ed.), Propalladia and other works of Bartolomé de Torres Naharro, Bryn Mawr- Pennsylvania, 1943-1951 [1943 (I), 1946 (II), 1951 (III)].

López Morales, H., (ed.), Comedias (Soldadesca, Ymenea y Aquilana), Madrid, Taurus, 1986.

McPheeters, D.W., (ed.), Comedias (Soldadesca, Tinellaria, Himenea), Madrid, Castalia, 1979.

Pérez Priego, M.A., (ed.), Obras completas de Bartolomé de Torres Naharro, Madrid, Turner, 1994.

Propalladia, ed. Facsimilar, Madrid, RAE, 1990.

\section{Catálogos: teatro español del s. XVI}

Barrera y Leirado, C. A. De la, Catálogo bibliográfico y biográfico del teatro antiguo español desde sus orígenes hasta mediados del s. VIII, Madrid, 1969, [1860].

Cotarelo Mori, E., Catálogo de obras dramáticas impresas, pero no conocidas hasta el presente, con un apéndice sobre algunas piezas raras o no conocidas de los antiguos teatros francés e italiano, Madrid, 1902.

García-Bermejo Giner, M. M., Catálogo del teatro español del siglo XVI, Salamanca, ed Universidad de Salamanca, 1996. 


\section{Estudios sobre Bartolomé de Torres Naharro}

Aliprandini, L. de, «La Tinellaria nella cultura italiana del primo Cinquecento», en Bartolomé de Torres Naharro, Comedia Tinelaria, Boloña, Arnaldo Forni Editore, 1985.

- «La representación en Roma de la Tinellaria de Torres Naharro», en El teatre durant l'Edat Mitjana i el Renaixement (Actes del I Simposi Internacional d'Historia del Teatre, Sitges), Barcelona, Universidad de Barcelona, 1986, pp. 127-35.

Bataillon, M., «Le Torres Naharro de Joseph E. Gillet», en Romance Philology, XXI, n² (1967), pp. 143-70.

Berthelot, A., «La Propalladia du Mans », en BHi, LVI, 1954, pp. 167-74.

Böhl de Faber, C., Teatro español anterior a Lope de Vega, Hamburgo, 1832.

Canet, J. L., «La primera réplica en la Propalladia de Torres Naharro», en Criticón, $83,2001$.

Corbató, H., «El Valenciano en la Propalladia de Torres Naharro », en $R P h$, III, 1950, pp. 262-70.

Cox Davis, N., «Torres Naharro's Comic Speakers : Tinellaria and Serafina », en $H R$, LVI, 1988, pp. 139-55.

Crawford, J.P.W., «A note on the Comedia Serafina of Torres Naharro », en MLN, XXXVI, 1921, pp. 15-17.

- "Who is the character of Divina in the comedia Jacinta», en $H R, \mathrm{~V}$, No. 1, 1937.

Croce, B., «La Propalladia de Torres Naharro» en Quaderni della critica, V, 1949, pp. 79-87.

- La Spagna nella vita italiana durante la Rinascenza, Bari, Gius. Laterza \& Figli, 1968 (colección artículos publicados en los años 1893-1906).

Escobar Borrego, F.J., Montero Delgado, J., «La Sátira Antirromana en la Obra Poética de Torres Naharro» Salamanca, Semyr, Universidad de Salamanca, 2005, pp. 387-398. 
Falconieri, J. V, «La situación de Torres Naharro en la historia literaria», en Hispanófila, I, 1957, pp. 32-40.

Fernández de Moratín, L., Orígenes del teatro español, en Bibliotéca de Autores Españoles, desde la formación del lenguaje hasta nuestros días, ordenada e ilustrada por Buenaventura Carlos Aribau, Madrid, Nueva Edición, 1944, [1830].

Ferrario de Ordina, L., «Sobre la Ymenea de Torres Naharro», en Studia Philologica et Letteraria in Honorem Leo Spitzer, Berne, Franche Verlag, 1968-70, pp. 259-65.

Gillet, J., Propalladia and other works of Bartolomé de Torres Naharro, (transcribed, edited and completed by O. H. Green), Philadelphia, University of Pennsylvania Press, 1961 (IV).

- «Une édition inconnue de la Propalladia de Torres Naharro», en $R R Q, \mathrm{XI}$, 1920, pp. 26-36.

- «The original version of Torres Naharro's Comedia Tinellaria», en $R R Q$, XIV, 1923, pp. 265-75.

- «Notes on the language of the rustics in the drama of the Sixteenth Century», en Homenaje a Ramón Menéndez Pidal, Madrid, 1925, vol.I, pp. 443-53.

- "Torres Naharro and the Spanish drama of the Sixteenth Century», en Estudios Eruditos in Memoriam de A. Bonilla y San Martín, Madrid, 1930, t.II, pp. 437-68.

- «The date of Torres Naharro's death», en HR, IV, 1936, págs. 41-46.

- «Torres Naharro and the Spanish drama of the Sixteenth Century», en $H R, \mathrm{~V}$, 1937, pp. 203-206.

- «Doña Bisodia y Santo Ficeto», en $H R, X, 1942,68-70$.

- «Spanish fantasía for presunción», en Studia Philologica et Litteraria in Honorem Leo Spitzer, Berne, Franche Verlag, 1958.

- Torres Naharro and the drama of the Renaissance, Transcribed, Edited and Completed by Green, O. H., en Propalladia and other works of Bartolomé de Torres Naharro, Philadelphia, University of Pennsylvania Press, 1961 (IV).

Gilman, S., «Retratos de conversos en la Comedia Jacinta de Torres Naharro», en NRFH, XVII, 1963-64, pp. 20-39. 
Giordano Gramegna, A., «Influencia italiana en Bartolomé Torres Naharro», en Teatros y prácticas escénicas: La comedia, (ed.) Juan Oleza, Londres, Tamesis Books-Institución Alfonso el Magnánimo, 1986, vol. II, pp. 11-49.

Grismer, R.L., "Another reminiscence of Plautus in the Comedias of Torres Naharro», en $H R$, VIII,1940, pp. 57-58.

Heugas, P., «Torres Naharro, raro inventor», en Homenaje a José Antonio Maravall, Madrid, Centro de Investigaciones Sociológicas, 1985, t. II, pp. 319-32.

Laitenberger, H., «Bartolomé de Torres Naharro, poeta y dramaturgo del amor cortés», en Homenaje a Alberto Navarro, 1990, pp. 321-46.

Lampillas Javier, Saggio storico apologético della letteratura spagnola contro le pregiudicate opinioni di alcuni moderni scrittori italiani. Dissertazioni del Signor Abate D. Saverio Lampillas, Parte II, Tomo IV, Génova, 1781.

Legarda, A. De, «Primera frase vasca impresa conocida en Torres Naharro», en Boletín de la real Sociedad Vascongada de Amigos del País, VII, 1934, pp. 161-74.

Lenz, A., «Torres Naharro et Plaute», en RHi, LVII, 1923, pp. 99-107.

Lida de Malkiel, M. R., «Del Renacimiento español: Bartolomé de Torres Naharro», en Sur, 211-12, 1952, pp. 119-23.

- «El fanfarrón en el teatro del Renacimiento», $R P h, 11$ (1958).

Lihani, J., Bartolomé de Torres Naharro, Boston, Twayne Publishers, 1979.

- «La contienda social en la 'Comedia Aquilina' de Bartolomé de Torres Naharro», en Homenaje a Josep Maria Solá-Solé, 1984, II, pp. 199-209.

López Prudencio, J., «Los Naharros de la Torre de Miguel Sesmero», en REE, VII, 1984, pp. 161-67.

Martínez de la Rosa, F., Obras literarias, París, 1827-30, tomo I, II.

Mazzei, P., Contributo allo studio delle fonti, specialmente italiane del teatro di Juan del Encina e Torres Naharro, Lucca, Amedei, 1922.

McGrady, D., «Buena ropa in Torres Naharro, Lope de Vega and Mateo Alemán», en $R P h, \mathrm{XXI}, 1967$, pp. 183-85.

- «Italian influences upon Torres Naharro's Comedia calamita», en $B C, \mathrm{XXXV}$, 1983, pp. 181-87. 
McCready, W., Bibliografía temática de estudios sobre el teatro español antiguo, Toronto, 1966.

Menéndez Pelayo, M., «Bartolomé de Torres Naharro y su Propaladia», Obras completas, Santander, CSIC, 1941, vol. VII.

- Prólogo a la Propalladia de Bartolomé de Torres Naharro, Madrid, Libros de Antaño de la Librería de los Bibliófilos, 1900, vol. II.

Oleza, J., «En torno a los últimos años de Bartolomé de Torres Naharro», en P. Garelli y G. Marchetto (eds.), Un 'Hombre de bien'. Saggi di lingue e letterature in onore di Rinaldo Froldi, Alessandria, Edizioni dell'Orso, 2004, pp. 233-248.

Pickering, T., "A note on the Comedia Serafina and El Conde Alarcos», en MLN, LXXI, 1956, pp. 109-114.

Révah, I.S., «Un tema de Torres Naharro y Gil Vicente», en NRFH, VII, 1953, pp. $417-25$.

Rodríguez-Moñino, A., «El teatro de Torres Naharro (1517-1936). Indicaciones bibliográficas», en Revista de Filología Española, XXIV (1937), pp. 37-82.

Romera-Navarro, M., «Estudio de la Comedia Himenea de Torres Naharro», en Romanic Review, XII (1921), pp. 50-72.

Segura Corvasí, E., "Aportaciones al estudio del lenguaje de Torres Naharro», en Revista del Centro de Estudios Extremeños, VIII (1934), pp. 211-241.

Signorelli, P. N., Storia critica dei Teatri Antichi e Moderni, libri III, Napoli, 1777, pp.. 254-257.

Sito Alba, M. «El teatro en el s. XVI (desde finales de la Edad Media hasta comienzos del siglo XVII)», en Historia del teatro en España, vol. I, de J. M. Díez Borque, , Madrid, Taurus, 1984, pp. 215-261.

Surtz, R.E. y Weinerth, N., «Algún diabro de fiesta: la Comedia Trofea de Bartolomé de Torres Naharro», en Torre, I, 1987, pp. 575-83.

Teijeiro Fuentes, M. Á., «El teatro extremeño en el siglo XVI. La Calamita de Torres Naharro», en REE, XLVI, $\mathrm{n}^{\circ} 2$, 1990, pp. 415-28.

- «Bartolomé de Torres Naharro», en El teatro en Extremadura en el siglo XVI, Excma. Diputación Provincial de Badajoz, 1997, pp. 83-203. 
Tesoro del teatro español desde sus orígenes hasta nuestros días, Tomo I, Librería europea de Baudry, París, 1838.

Ulysse, G., «La Soldatesca de Bartolomé de Torres Naharro et la comédie italienne de son temps», en Etudes Hispano-Italiennes, I, 1987, pp. 163-82.

Weinerth, N., «Bartolomé de Torres Naharro's Diálogo del Nascimiento: A conversos christmas play», en Revista de Estudios Hispánicos de Puerto Rico, IX, 1982, pp. 249-54.

Zimic, S., «El pensamiento humanístico y satírico de Torres Naharro», Santander, Boletín de la Biblioteca de Manéndez Pelayo, LII, 1976, pp. 21-100; LIII, 1977, pp. 61-306; LIV, 1978, pp. 2-279.

\section{Estudios generales}

AA.VV, Director Oleza Simó, J., Teatros y prácticas escénicas I. El Quinientos Valenciano, Institució Alfons el Magnànim, 1984.

- Teatros y prácticas escénicas II. La Comedia, London, Tamesis Books Limited, en Colaboración con Institución Alfonso el Magnánimo, 1986.

Aliprandini de, L., "Il teatro spagnolo", en Il Teatro. Repertorio dalle origini a oggi, Mondadori, Milano, 1982, pp. 441-494 y 502-536.

Bataillon, Marcel, La Célestine selon Fernando De Rojas, Paris, Didier, 1961.

Crawford, J.P., Wickersham, Spanish Drama before Lope de Vega, Filadelfia, III ${ }^{\mathrm{a}}$ ed., 1967.

Cruciani, F., Teatro nel Rinascimento. Roma 1450-1550, Roma, Bulzoni, 1983.

Cruciani, F., Seragnoli, F., (edición) Il teatro italiano nel Rinascimento, Bologna, Il Mulino, 1987.

Chartier R., In scena e in pagina. Editoria e teatro in Europa tra XVI e XVIII secolo, Milano, Sylvestre Bonnard, 2001;

- Cultura scritta e società, Milano, Sylvestre Bonnard, 1999.

De Marinis, M., Comprender el teatro, lineamientos de una nueva teatrología, Buenos Aires, Ed. Galerna, 1997, trad. A.C. Prenz. 
Diago, M. V., Ferrer, T., (eds.), Comedias y comediantes, estudios sobre el teatro clásico español, Universitat de València, Departament de filologia espanyola, 1991.

Díez Borque, J. M., (dir), Historia del teatro en España, vol.I: Edad Media, Siglo XVI, Siglo XVII, Madrid, Taurus, 1984.

- Teoría, forma y función del teatro español de los Siglo de Oro, Barcelona, Oro Viejo Colección de crítica literaria, José J. de Olañeta Editor, 1996.

- Los géneros dramáticos en el siglo XVI (El teatro hasta Lope de Vega), Madrid, Taurus, 1987.

Di Pasterna, E., «hacia la edición crítica de La hermosura aborrecida de Lope de Vega», en Criticón, 87-88-89, 2003.

Ferracuti, G., «Opera buffa: teatro e cultura popolare nella letteratura spagnola del Rinascimento», Monografía de Lengua y Literatura Española, Universidad de Trieste, 1997-1998.

Ferrone, S., Commedie dell'Arte, Milano, Mursia, 1985.

Gilman, S., La Celestina: arte y estructura, Madrid, Taurus, 1978, 1982².

- La españa de Fernando de Rojas, Madrid, Taurus, 1978.

Hermenegildo, A., (ed.), Teatro Renacentista, Madrid, Colección Austral, Espasa Calpe, 1990.

- El Teatro del Siglo XVI, Madrid, Júcar, 1994.

- Renacimiento, teatro y sociedad. Vida y obra de Lucas Fernández, Madrid, Cincel, 1975.

- Juegos dramáticos de la locura festiva, pastores, simples, bobos, graciosos del teatro clásico español, Palma de Mallorca, Oro Viejo Colección de crítica literaria, José J. de Olañeta Editor,1995.

- (ed.), Teatro español del siglo XVI. Del palacio al corral, Madrid, ed. Biblioteca Nueva, 1998.

Heugas, P., La Celestine et sa descendance directe, Bordeaux, 1973.

Huerta Calvo, J., El teatro medieval y renacentista, Madrid, ed. Mayor, 1984. 
- Historia del teatro español De la Edad Media a los Siglos de Oro, vol.I, Madrid, ed. Gredos, 2003.

- El nuevo mundo de la risa, Palma de Mallorca, Oro Viejo, Colección de crítica literaria, José J. de Olañeta Editor,1995.

- «La teoría literaria de Mijail Bajtín (Apuntes y textos para su introducción en España)» en Dicenda: Cuadernos de filología hispánica, $\mathrm{N}^{\circ} 1$, Universidad Complutense de Madrid, 1982, pp. 143-158.

- «El lugar del teatro en la poética de Mijaíl Bajtín», Congreso en Madrid, 4-6 de julio de 1994, actas en José Romera Castillo, Mario García-Page y Francisco Gutiérrez Carbajo (eds.), Bajtín y la literatura, Madrid, Visor Libros 1995, pp. 459, con presentación de José Romera.

Lázaro Carreter, F., Teatro medieval, Madrid, Castalia , 1976 (IV ed.).

Lida de Malkiel, M.R., La originalidad artística de la Celestina, Buenos Aires, Eudeba, 1962.

López Estrada, F., Introducción a la literatura medieval española, Madrid, Gredos, 1979, (IV edición).

López Morales, H., Tradición y creación en los orígenes del teatro castellano, Madrid, Alcalá, 1968.

Maravall, José Antonio, El mundo social de La Celestina, Madrid, Gredos, 1968.

- Teatro y Literatura en la sociedad barroca, Barcelona, Crítica, 1990.

Georgina Masson, Cortigiane italiane del Rinascimento, Roma, 1981.

Menéndez Pidal, R., Poesía juglaresca y orígenes de las literaturas románicas, Madrid, Istituto de Estudios políticos, 1957.

Menéndez Pidal, Ramón, Poesía juglaresca y juglares. Orígenes de las literaturas románicas, Madrid, Espasa Calpe, 1991, ed. Ampliada, [1942].

Morón Arroyo, Ciriaco, Sentido y forma de La Celestina, Madrid, Cátedra, 1974.

Nicoll, A., Masks, mimes, and miracles. Studies in the popular theatre, New York, Cooper Square Publishers, 1963.

Olson, E., Wardropper, B.W., Teoría de la Comedia, Barcelona, Ariel, 1978. 
Pavis, P. Diccionario del teatro. Dramaturgia, estética, semiología, Barcelona, Paidós Comunicación, 1990, $\mathrm{I}^{\mathrm{a}}$ reimpresión.

Pérez Priego, M. A., (edición), Teatro renacentista, Barcelona, Plaza\&Janés, 1987.

- Estudios sobre el teatro del Renacimiento, Madrid, UNED, 1998

- Cuatro comedias celestinescas, UNED, Univ. De Sevilla, Univ. De Valencia, 1993.

Profeti, M. G., Introduzione allo studio del teatro spagnolo, Firenze, La casa Usher, 1994.

Rendina, C., I Papi Storia e segreti, Newton \& Compton editori, Roma 2005, (VIII edición) [1983].

Rico F., López Estrada F., Historia y Crítica de la Literatura española, Siglos de oro: Renacimiento, Crítica, 1980.

Ruiz Ramón, F., Historia del teatro español (desde sus orígenes hasta 1900), Madrid, Cátedra 2000 (décima edición), [1966].

Russell, P. E., Introducción a La Celestina comedia o tragicomedia de Calisto y Melibea, Madrid, Clásicos Castalia, 1991.

Salomon, N., Lo villano en el teatro del siglo de oro, Castalia, Madrid, 1985.

Samoná, Carmelo, Aspetti del retoricismo della Celestina, Roma, 1953.

Samonà, C., Mancini, G., Guazzelli,F., Martinengo, A., La letteratura spagnola. I Secoli d'Oro, Milano, BUR, 1993.

Sánchez Escribano, F., Porqueras Mayo, A., Preceptiva dramática española del renacimiento y el barroco, Madrid, Gredos, 1972.

Stern, Ch., «The Early Spanish Drama: from Madieval Ritual to Renaissance Art», en "Renaissance Drama", VI, 1974, pp. 177-223.

Strong, R., Arte e potere. Le feste del Rinascimento 1450-1650, Milano, Mondadori, 1987.

Shoemaker, Ronald B., The Multiple Stage in Spain during the Fifteenth and Sixteenth Centuries, Princeton, 1935, traducción española en Estudios Escénicos, 2, 1957, pp. 1-154. 
Ulysse, G., en Cruciani, F., Seragnoli, F., Il teatro italiano nel Rinascimento, Bologna, Il Mulino, 1987.

Wellek, R., Storia della critica moderna VII. Germania, Russia ed Europa orientale 1900-1950, Società editrice Il Mulino, 1995.

Wickham, G., Storia del teatro, Il Mulino, 1988, trad, italiana Clelia Falletti. Título original A History of the Theatre, Oxford, Phaidon Press Limited, 1985.

Wilson E. M. y Moir D., Historia de la literatura española 3. Siglo de oro: teatro Ariel, 1974

\section{Relaciones literarias hispano-italianas}

Arce, J., Literaturas Italiana y Española frente a frente, Madrid, Espasa-Calpe, 1982.

Arroniz, O., La influencia italiana en el nacimiento de la comedia española, Madrid, Gredos, 1969.

Beccaria, G.L., Spagnolo e spagnoli in Italia, Torino, Giappichelli, 1967.

Croce, B., La Spagna nella vita italiana durante la Rinascenza, Bari, Gius. Laterza \& Figli, 1968.

Gnisci, A., Sinopoli, F., Letteratura comparata. Storia e testi, Roma, Sovera, 1995.

Mazzei, P., Contributo allo studio delle fonti, specialmente italiane, del teatro di Juan del Enzina e Torres Naharro, Lucca, Tipografia Amedei, 1922.

Meregalli, F., Presenza della Letteratura spagnola in Italia, Firenze, Sansoni, 1974.

Siracusa, J., Laurenti,L., Relaciones literarias entre España e Italia: ensayo de literatura comparada, Boston, 1972.

Vasoli, C., «Aspetti dei rapporti culturali tra Italia e Spagna nell'età del Rinascimento», in La cultura delle corti, Bologna, Cappelli editore, 1980. 


\section{Cultura y literatura popular}

AA.VV, Cultura popular y cultura de masas, Buenos Aires, Paidós, 2000.

Amícola, J., De la forma a la información. Bajtín y Lotman en el debate con el formalismo ruso, Rosario, Beatriz Viterbo Editora, Orbis Tertius, 2001, I ${ }^{\text {a }}$ reimpresión, [1997].

Bajtín Mijail, La cultura popular en la Edad Media y en el Renacimiento, el contexto se François Rabelais, Madrid, Alianza ed., 2003, III ${ }^{\mathrm{a}}$ reimpresión, versión de Julio Forcat y César Conroy, [1965].

- Dostoevskij, poetica e stilistica, Torino, Einaudi, 1968 (2 $2^{\mathrm{a}}$ ed.), trad. G. Garritano, [1963].

- L'autore e l'eroe, teoria letteraria e scienze umane, ed. Strada Jovanovic, C., Torino, Einaudi, 1988, [1979].

- Esthétique et théorie du roman, París, Gallimard, 1978, trad. D. Olivier, préface de Michel Aucouturier, [1975].

Barrientos, J.A., Rodrígues Sánchez de León, M.J., Diccionario de Literatura popular, Salamanca, ed. Colegio de España, 1997.

Bell, D., The End of Ideology, Illinois, Glencoe, 1960;

- «Modernidad y sociedad de masas: variedad de las experiencias culturales», en Industria cultural y sociedad de masas, Caracas, Monte Ávila, 1974.

Bosisio, P., Popolaritá e classicitá nel teatro comico del Cinquecento, Milano, Principato, 1975.

Burke, P., Cultura popolare nell'Europa moderna, Milano, Mondadori, 1980.

- Il Rinascimento, Bologna, Il Mulino, 1990.

Caro Baroja, J., Teatro popular y magia, Madrid, Revista de Occidente, 1974;

- El Carnaval, Madrid, Taurus, 1965.

- «La littérature de cordel et les pièces à machines au XVIIIème siècle», Colloque sur le concept du populaire dans la littérature espagnole. Mélanges de la Casa de Velázquez, X, 1974. 
- Ensayo sobre Literatura de Cordel, Madrid, Istmo, 1990.

Chartier, R., «Letture 'popolari'», in Cultura scritta e società, Milano, Sylvestre Bonnard, 1999.

Díaz, L., «Concepto de la literatura popular y conceptos conexos», en «Anthropos», Literatura Popular, 166/167 (mayo-agosto), Barcelona, 1995.

García Canclini, N., Las culturas populares en el capitalismo, México, Nueva Imagen, 1982.

- «¿De qué estamos hablando cuando hablamos de lo popular? en Comunicación y culturas populares en Latinoamérica, Seminario del Consejo Latinoamericano de Ciencias Sociales, FELAFACSCE, México, Grijalbo, 1987.

- Culturas híbridas, México, Grijalbo, 1990.

- «Culturas populares, culturas híbridas, cultura del consumo», entrevista en «Causas y azares», año II, n², otoño $1995^{\mathrm{a}}$.

García de Enterría, M.C., Sociedad y poesía de cordel en el Barroco, Madrid, Taurus, 1973.

- Estudio introductorio, en «Anthropos», Literatura Popular, 166/167 (mayoagosto), Barcelona, 1995.

- Voz «popular» en Barrientos, J.A., Rodrígues Sánchez de León, M.J., Diccionario de Literatura popular, Salamanca, ed. Colegio de España, 1997.

Geertz, C., Interpretazione di culture, Bologna, il Mulino, 1998.

Ginzburg, C., Il formaggio e i vermi - Il cosmo di un mugnaio del '500, Torino, Einaudi, 1999, [1976].

Grignon, C., Passeron, J.C., Lo culto y lo popular, Miserabilismo y populismo en sociología y en literatura, Buenos Aires, Ediciones Nueva Visión, 1989.

Haymann, D., «Más allá de Bajtín: hacia una mecánica de la farsa», en «Humor, ironía, parodia Espiral», 7, Madrid, Fundamentos, 1980, pp- 69-117.

Jachia, P., Introduzione a Bachtin, Roma-Bari, Laterza, 1992.

Literatura Popular, «Anthropos», 166/167 (mayo-agosto), Barcelona, 1995, 
Nicoll, A., Masks, mimes, and miracles. Studies in the popular theatre, New York, Cooper Square Publishers, 1963.

Rochon, A., Letteratura e società nel Rinascimento italiano, in Il Rinascimento. Aspetti e problemi attuali, Firenze, Leo S. Olschki editore, 1982.

Williams, R., Keywords. A vocabulary of culture and society, London, Fontana, 1976, pp. 76-82.

- «The Idea of Culture», in McIlroy John, y Westwood Sallie, Border Country: Raymond Williams in Adult Education, Leicester, 1990.

- Sociologia della cultura, Bologna, il Mulino, 1983.

Zumthor, P., Introduction à la poesie orale, París, Seuil, 1983.

\section{Obras literarias citadas}

Delicado, F., ed. Ángel Chiclana, La lozana andaluza, Madrid, Espasa Calpe, 1988.

Erasmo de Rotterdam, Moriae elogium, id est, Stulticiae laus; Elogio alla follia, Roma, Get Newton, 2003², Introducción de Miccoli Paolo, Edición y traducción del latín D’Anna Gabriella, versión bilingüe latín-italiano.

- Dulce bellum inexpertis, Opera Omnia, vol II.

Machiavelli, N., Lettere, Milano, Feltrinelli, 1961, (ed.) Gaeta F..

Mujica Lainez, M., Bomarzo, Buenos Aires, ed. Sudamericana, 1967, III edición.

Rojas, F. de, La Celestina, Madrid, Cátedra, 2000.

Sanudo, M., Diarii (1496-1533), ed. por R. Fulin et al., Venezia, Fratelli Vicentini, 1879-1913, XIX.

Valdés, Juan de, Diálogo de la lengua, Madrid, Clásicos Castalia, 1985.

Villalón, Cristobal de, Ingeniosa comparación entre lo antiguo y lo presente, Madrid, Sociedad de Bibliófilos Españoles, 1898. 


\section{Diccionarios consultados para la traducción del Apéndice:}

Diccionario de Autoridades, Real Academia Española, ed. facsímil, Gredos, 1990, $1^{\text {a }}$ ed., 3 vols.

Diccionario Crítico Etimológico Castellano e Hispánico, Joan Corominas, Madrid, Gredos, 1980-1991, 6 vols.

Diccionario de la Lengua Española, Real Academia Española, Espasa Calpe S.A., $22^{\mathrm{a}}$ ed., 2 vols.

Dizionario della Lingua Italiana, Giacomo Devoto, Gian Carlo Oli, Le Monnier, 2004 [1979].

Dizionario Fraseologico Completo Spagnolo Italiano-Italiano Spagnolo, S Carbonell, Hoepli, Milano, 1981, 2 vols.

Tesoro de la Lengua Castellana o Española, Sebastián de Covarrubias Horozco, Edición integral e ilustrada, de Ignacio Arellano y Rafael Zafra, IberoamericanaVervuert, Madrid, 2006.

Vocabolario della Lingua Italiana, Nicola Zingarelli, Zanichelli, Bologna, $2002,11^{\mathrm{a}}$ ed.

Vocabulario de refranes y frases proverbiales y otras fórmulas comunes a la lengua castellana, Gonzalo Correas, ed. de L. Combet, revisada por R. Jammes y M. Mir-Andreu, Madrid, Castalia, 2000. 


\section{Apéndice}

\section{$\underline{\text { Traducción de la comedia Tinellaria al italiano }}$}

\section{Nota a la traducción}

La inserción como apéndice de la traducción al italiano de Tinellaria en el presente trabajo merece una breve explicación. En su intento de definir el significado, Roman Jakobson escribió que «el significado es lo que se traduce», con lo cual consideraba que el mismo podía definirse a través de una operación de traducción. Al iniciar nuestra investigación, consideramos que dicha operación a través de las diferentes etapas que la misma supone y por la atención que requiere, contribuiría, en muchos aspectos -también en nuestro trabajo-, a aclararnos dudas o a replantear algunos interrogantes, como, asimismo, permitirnos acceder a una ampliación del significado que la mera lectura -aunque sea atenta- no siempre puede garantizar. En este sentido, entendemos que la traducción puede convertirse en la más atenta de las lecturas.

En esta explicación, nos parece importante subrayar que este apéndice no es un simple agregado, sino que estuvo presente, de un modo concreto, en el proceso real de nuestro trabajo. Cada vez que la comedia Tinellaria entraba en cuestión, el remitir a la misma implicaba necesariamente remitir a la traducción, espacio en el que convergían, de un modo más seguro, en sus diversas facetas, los múltiples elementos de su problemática: traducir era entender a fondo.

Fue, pues, a través de la operación de traducción que se nos aclararon algunos aspectos del texto original. En este sentido, resultaron también más claras algunas interferencias lingüísticas del italiano en el texto original, hecho que ha enriquecido nuestra concepción sobre la lengua particular de Torres Naharro y que, de alguna forma, está presente en el espíritu de nuestro trabajo. La lengua italiana se convierte en el proceso de traducción en un pilar de comprensión 
intercultural. La contigüidad, una vez más, asume una relevancia particular también en la aproximación entre el castellano y el italiano. Se trata también en lo lingüístico de una sfumatura renacentista.

Para la traducción hemos consultado las Notas del III volumen de Propalladia and other works of Bartolomé de Torres Naharro, editado por Gillet, J.E., Bryn Mawr- Pennsylvania, 1951, que ha sido el pilar para esta traducción. Las interpretaciones del crítico, en los puntos oscuros del texto, fueron referentes esenciales para esta versión en lengua italiana.

En el presente trabajo de traducción utilizamos, en las notas a pie de página, las siguientes abreviaturas:

TLCE

VR

$\mathrm{DECH}$

DLE

VLI
Tesoro de la lengua castellana o española

Vocabulario de refranes y frases proverbiales y otras fórmulas comunes a la lengua castellana,

Diccionario de Autoridades

Diccionario crítico etimológico castellano e hispánico

Diccionario de la Lengua española

Vocabolario della Lingua Italiana, Zingarelli. 
COMMEDIA TINELLARIA 
Fino a qui in modo eccellente mi ha servito la mia sorte, che mi ha condotto in presenza di una così alta compagnia.

Certamente,

servire gente così nobile non è stato un brutto pensiero se il servizio è adeguato

a tanto merito

che in verità benché guidi la volontà, se la dottrina non accompagna, davanti a tanta maestà chi più osa più s'inganna.

Quale poeta

e a quale persona discreta basta l'animo, insomma, non per mettersi a servirvi ma che solo presuma pensarlo?

Certo, credo

converrebbe del desiderio

fare lingue e discorsi

come fanno, per quanto vedo, della pasta maccheroni.

Suvvia!

Che la grandezza del mare,

dove qualunque fiume si espande, è solito mostrare la stessa faccia al piccolo come al grande.

Ora, dunque, se i miei versi hanno piedi variis linguis diano dei calci que vatibus hic mos est centum his poscere voces. ${ }^{1}$

Vi assicuro

che si sono viste, in effetti, poche di queste commedie; dico, che il loro soggetto vuole cento lingue e bocche, di cui

alcune sono le più comuni nei tinelli di Roma, non tutte così importanti ma qualche parte hanno. Vedrete voi:

¡Jur’a Dio! ¡Voto a Dios!

¡Per mon arma! ¡Bay fedea!

¡Io, bi Got! y ¡Cul y cos!

¡Boa fe, naun, canada e mea!...2

Di questa gente ${ }^{3}$

\footnotetext{
${ }^{1}$ Ora, dunque, / se i miei versi hanno piedi / calcino in varie lingue / perché i profeti sono soliti / necessitare cento voci.

${ }^{2}$ Giuro su Dio ! Voto a Dios! / Per l’anima mia! / Sí, per la mia fede! / Sí, per Dio! e Culo e corpo! / Davvero, uno no, due litri e mezzo.
} 
va toccando brevemente

tutto il resto è castigliano,

che è un parlare più conveniente

per qualsiasi cortigiano;

che l'autore,

con il desiderio e l'amore

con cui procura servirvi

si è messo a lavorare

sulla commedia futura.

E secondo me,

quelli che potranno seguirla

vinceranno il paradiso

e non solo un grande piacere

ma anche un grande e utile avviso;

i maggiori [benefici]

che a questi gran signori

ora potrebbero venire

è scoprire come i loro servitori

pensano ad altro che a servire.

Di continuo

i pomeriggi e le mattine

li vedrete ${ }^{4}$ a far la guerra

alle povere cantine

fino a metterle sotto sopra!

Davvero

si trovano le bottiglie

buttate negli angoli

scorticando le pagnotte

bruciando il carbone.

E nemiche

queste persone delle fatiche

ma non degli inganni:

concili, bande e alleanze

quattrocento ogni dì.

Se aspettate

ora vedremo

ciò che avete udito

perché qui ridiate

e a casa lo castighiate.

Dunque, signori miei,

abbiamo intitolato la commedia,

da tinello, Tinellaria,

come notiamo in Plauto

cha da asino disse Asinaria.

E fra di noi,

tinello e asino, per Dio

non differiscono in nulla

perché già vedete che entrambi

si comandano a bastonate.

Per cui spero

che a tutti quanti

vi faremo ridere,

come quel falegname ${ }^{5}$

\footnotetext{
${ }^{3}$ Sujeto: la comedia
}

${ }^{4}$ Sujeto: los sirvientes 
che desiderava servirvi.

Da qui

credete, signori, in me

se l'autore in qualcosa ha errato,

è per ignoranza, sì

ma per malizia, no.

La durata

può essere di due ore

poco più, come io presumo

con ciò voglio ora raccontare

un po' dell'argomento.

\section{ARGOMENTO}

Dalla provincia d'Egitto

venne a Roma un gran dottore,

a cui Papa Benedetto

ricevette con grande onore;

e così è

che arrivò a baciare i piedi

del Papa con grande desiderio,

e fu alloggiato poi

in quel grande Colisseo.

Dove giunto,

essendo un uomo stimato,

le sue lettere degne di alloro,

gli diedero un vescovato

della Scala di San Pietro.

Presto,

essendo la sua fama eccellente,

fu Cardinale di San Giano

e chiamato volgarmente

il Cardinale del Baccano.

La sua famiglia, ${ }^{6}$

ricca e grande a meraviglia

parla variis linguis che vedrete

anche se, ${ }^{7}$ saranno in castigliano delle

sette parti, sei.

trionfavano;

miglior tinello davano loro

che ad alcuni cardinali

ma tutto rubavano

i traditori ufficiali. ${ }^{8}$

I suoi soggetti [del cardinale]

subbivano tali effetti

che se la passavano male

i ventri dei poveretti

\footnotetext{
${ }^{5}$ D.W. Mc Pheeters (1979) en su edición de la comedia escribe al respecto: «Puede ser alusión a cualquier tentativa de volar hecha a principios del siglo XVI. Recordemos las máquinas voladoras dibujadas por Leonardo da Vinci» (nota 5).

${ }^{6}$ Familla, famiglia, puede referirse de manera alusiva a la familia como a toda la gente que lo acompaña, incluso a los servidores. (...) variis linguis que veréis, como dijo en el introito los personajes hablan varias lenguas; repite el concepto y subraya que en la comedia lo van a ver. (...) bien que serán de Castilla /de siete partes las seis, se habla en varias lenguas aunque sei séptimos de la comedia están en castellano.

${ }^{7}$ En la comedia.

${ }^{8}$ Sirvientes principales. Se ocupan de mantener el buen orden y funcionamiento del tinello.
} 
e l'onore del Cardinale.

$\mathrm{E}$ avviene

che la famiglia patisce

per questa scortesia

e quelli, come sembra,

si ubriacano ogni giorno.

Volete vedere?

ora verranno a mangiare

in questo santo tinello;

coloro che attendete

non potranno tardare un attimo.

E sento che

questo basta per il racconto,

non vi dico i loro nomi

ma il tinello e l'argomento

oggi lo ignorano pochi uomini.

A mangiare

potete aggiungervi

quelli che non lo avete fatto

con un reale singolare

e uno sgabello dove sedervi.

Ma non aspettiamo oltre,

perché arriva il credenziere

dicono che si chiama Barabba

nome come carne e pelle

così congiunto con la sua fama. 


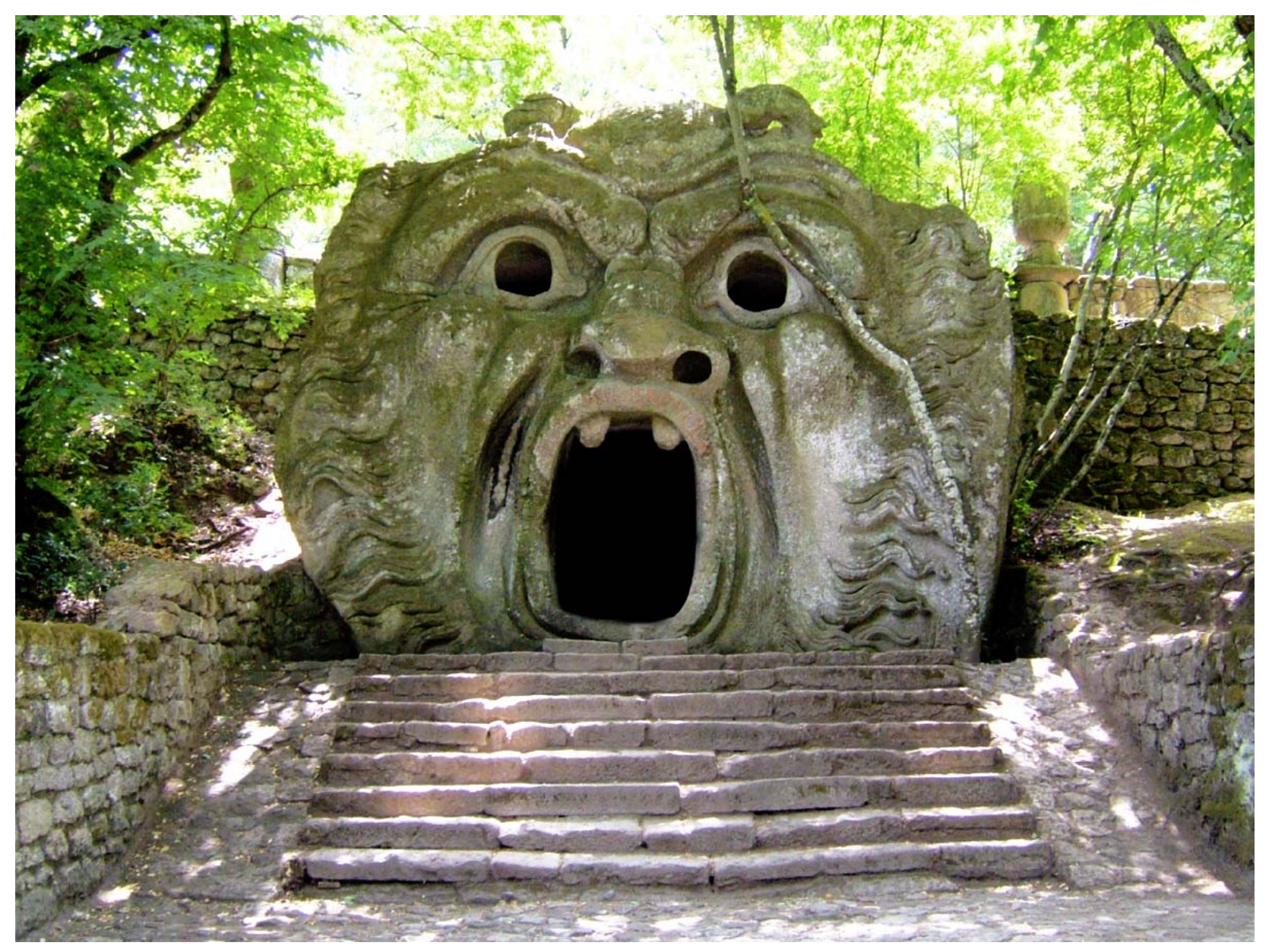

El Ogro, Parque de los monstruos, Bomarzo 
Barabba, credenziere. Lucrezia, lavandaia. Escalco. ${ }^{9}$ Metreianes. Mattia, servo.

\begin{tabular}{|c|c|c|}
\hline BARABBA & $\begin{array}{l}\text { Questa nostra lavandaia } \\
\text { non viene con le tovaglie. } \\
\text { Ma che pensa la schioppettiera } \\
\text { Che sono uno sventato? } \\
\text { Va già male } \\
\text { Per la vita del Cardinale } \\
\text { le farò avere una batosta } \\
\text { e che ancora non trovi un altro } \\
\text { credenziere del tinello. } \\
\text { Di continuo } \\
\text { le do pane e carne e vino, } \\
\text { che sommano buoni quattrini, } \\
\text { e ogni volta almeno } \\
\text { si porta via cinque carlini. } \\
\text { Ancora } \\
\text { so io che trionferebbe, } \\
\text { e con lei anche le sue vicine, } \\
\text { poiché solo con il pane potrebbe } \\
\text { mantenere cento galline. } \\
\text { Ma è testarda } \\
\text { Molte volte le dico: Lucrezia, } \\
\text { tieniti caro il mio buon partito, } \\
\text { ma il bene non si apprezza mai } \\
\text { finché non è perduto. } \\
\text { Ma, suvvia } \\
\text { che a me non può mancare } \\
\text { grazie ai miei denari il vino } \\
\text { e lei spero di arrivare } \\
\text { a vederla morir di fame. } \\
\text { E sono due. }\end{array}$ & 200 \\
\hline $\begin{array}{l}\text { LUCREZIA } \\
\text { BARABBA }\end{array}$ & $\begin{array}{l}\text { Buon giorno a te. } \\
\text { ¡Oh, che gran miracolo! } \\
\text { E buona notte a voi, } \\
\text { perché è la metà dell'anno. }\end{array}$ & 205 \\
\hline $\begin{array}{l}\text { LUCREZIA } \\
\text { BARABBA }\end{array}$ & $\begin{array}{l}\text { Ho fatto tardi? } \\
\text { Tanto da farmi arrabbiare } \\
\text { che farei scintille. }\end{array}$ & 210 \\
\hline LUCREZIA & $\begin{array}{l}\text { Ti giuro che ho aspettato } \\
\text { che suonassero le campanelle. } \\
\text { Che piacere! } \\
\text { Dimmi, chi deve aspettare } \\
\text { se ragioni come al solito }\end{array}$ & 215 \\
\hline
\end{tabular}

\footnotetext{
${ }^{9}$ «Del longobardo skalk que significa siervo. 1. Siervo encargado de trinchar las viandas en las mesas de los señores medievales y renacentistas; 2. En la antigua corte pontificia, el camarero que servía en la mesa del Papa», en VLI (trad. A.C.P).

En Gillet (III, 469): «Quegli, che ordina il convito, e mette in tavola la vivanda; e anche, quegli, che la trincia... He gives orders to Barrabás, the credenciero».
} 
le tovaglie il mangiare

o il mangiare le tovaglie?

LUCREZIA Non so niente.

Comunque sia stata allevata

sono sempre stata servita,

so ben poco del lavar i panni

e ancor meno di questa vita.

BARABBA Guai a me!

È da dieci anni che ti vedo

abitare nel Vecchio Borgo,

e da sempre ti conosco

come lavandaia pubblica. ${ }^{10}$

LUCREZIA Come cosa?

Non è da tanto che mi sono sposata:

guarda come menti bene,

ebbene sono stata abbastanza, davvero,

con il meschino di mio marito.

BARABBA Se vuoi,

dimmi quanti anni hai,

non negarmi la verità.

LUCREZIA Ventidue, per Dio, non di più, gli ho compiuti a Natale.

BARABBA Ora, dunque,

non voglio essere scortese,

ma, con l'aiuto di Dio,

credo che ne ha ventitre

e dice che ne ha ventidue.

LUCREZIA Dì, dunque, sù

che quella che è da te corteggiata

si può dare per pazza

io non sono mai stata vecchia e brutta

se non nella tua bocca maledetta.

Ay, persa!

Che nessuno in questa vita

mi ha così maltrattata,

né un uomo meno amata

né meno accarezzata.

E anche ieri,

per aver voluto amarti,

cosa che non mi conviene,

ho lasciato un mercante

che mi avrebbe dato quanto ha.

E ancora lo farebbe

andando da lui mi rivestirebbe,

e oggi mi prega d'ora in ora

e a casa sua mi terrebbe

servita come una signora.

Disgraziato,

dimmi, dove avresti trovato

un'altra sciocca come me,

che per te avrebbe negato

anche la madre che l'ha partorita?

Ricordo bene

che chi semina in una terra sterile

${ }^{10}$ Lavandera de concejo: « That is public, for hire to any one» (Gillet, 1951, III, 466, n. 54). 
BARABBA Taci, sposa;

per così poca cosa

non ti arrabbiare con me

che non esiste dama più bella, se mi chiedono, ai miei occhi.

Che vuoi ancora?

Vecchia o giovane, che tu sia, io amo di più le tue ciabatte ${ }^{11}$

che tutte quante le donne

venute dalla Castiglia.

LUCREZIA

Sì, certo.

Il tuo amare, nascosto

che non ha memoria di me,

o l'amare di chi è morto?

Abbia Dio in gloria la sua anima.

BARABBA Dì, chi è?

LUCREZIA Già te ne esci ${ }^{12}$

per sapere chi avrei detto ...

La mia signora donna Inés

che non avrebbe mai dovuto morire!

Con quale desiderio,

più che verso tutte le mie sorelle

ebbe nei miei confronti grande amore

e mi diede cose eleganti,

anche se io ero la minore!

Se arrivava

qualche cosa di valore

dalla India o da Venezia,

a quel punto diceva:

«Questo è per Lucrezia».

Che signora!

Se fosse ancora viva,

mai tu, traditore crudele,

mi faresti ingoiare d'ora in ora

sorsi di fiele amaro

come fai.

Ma tu mi perderai

per la brutta vita che mi dai,

e poi mi loderai

quando mi avrai persa.

BARABBA Taci, amica, non ti affaticare tanto perché mi burlo di te,

che qualunque ragione mi obbliga

ad esserti buon amico.

LUCREZIA Ay, che discorso

Se Dio mi guida in questo modo

io sarò ben liberata

\footnotetext{
${ }^{11}$ Xervilla, servilla: «Especie de calzado, que son unas zapatillas de cordovan con una suela delgada. Covarr. quiere se llamase así, porque las usan las siervas, o mozas de servicios; pero es mas natural venga del Arábigo, y en su rigor se llaman xervillas. Lat. Calceamentum servile», en DA.

${ }^{12}$ Ya salías al través. Al través: «Modo adverbial, que vale por algunos de los lados, y no rectamente», en DA.
} 


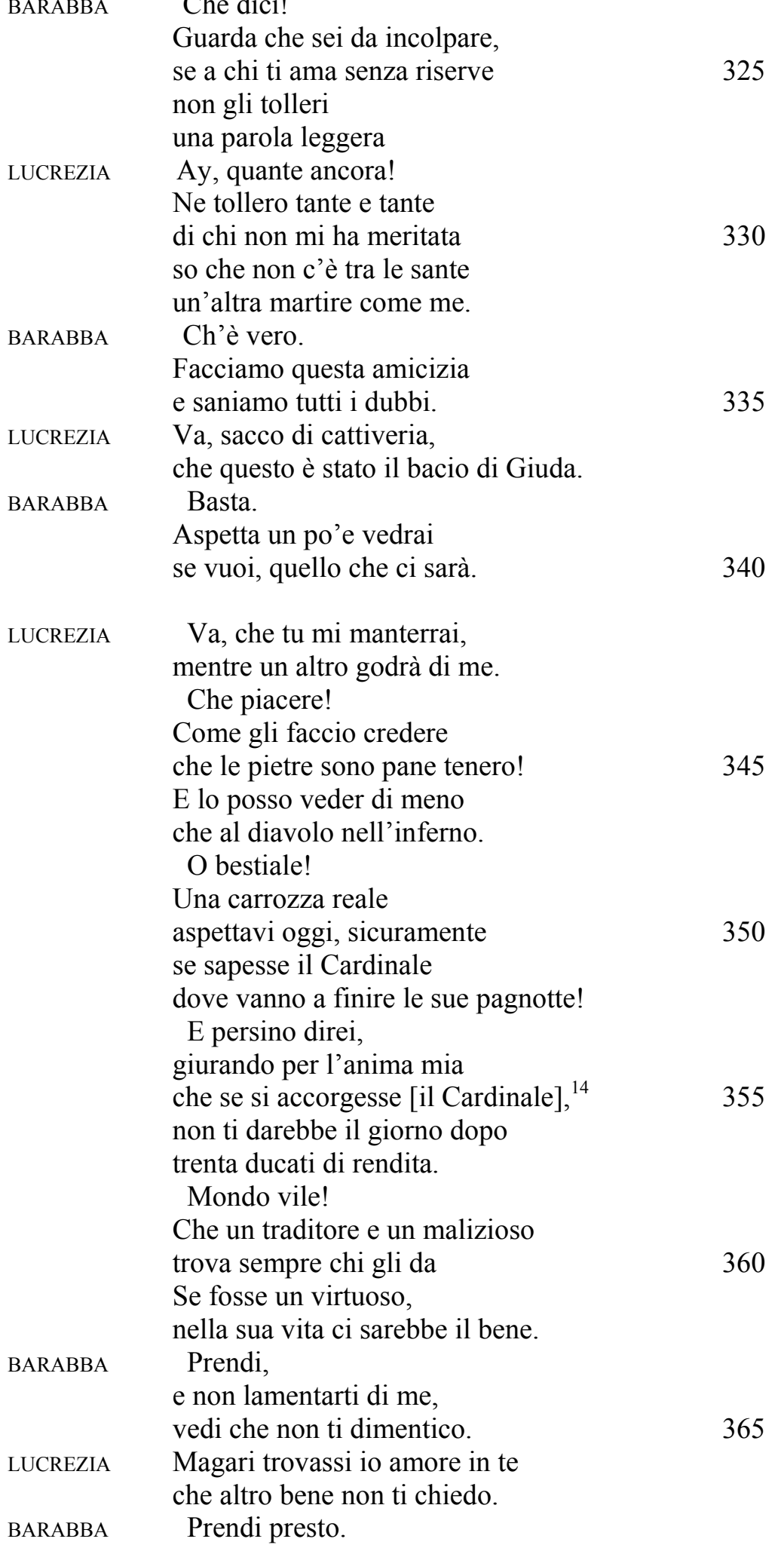

\footnotetext{
${ }^{13}$ Descalabrar: «Herir en la cabeza, rompiéndola con pietra, palo u otra cosa. Covarr. siente puede tener su origen del nombre Calabéra, y que añadida la preposición des se dixo descalaberar, y de allí con corta corrupción descalabrar», en DA.

${ }^{14}$ Caer en la cuenta: «Advertir algún error que se había concebido, y estaba remoto del conocimiento, y también en los yerros de la vida quando se corrige y sale del desorden que se ha tenido en ella. Lat. In milioren mentem venire», en DA.
} 
Vai ora via con questo

bada a coprirlo,

io farò poi il resto

quando andrò a dormire

LUCREZIA A cena

non farmi aspettare.

BARABBA Se tardassi, cena e taci,

che io non posso mancare

di adempiere con la canaglia.

Se mi aspetti, porterò ${ }^{15}$ ad ogni modo

i miei polli con il lardo,

pane bianco, buon formaggio e pere,

e un paio di boccali di vino

LUCREZIA Così farò

BARABBA Tarderò solo un'ora,

per questo voglio che mi aspetti.

Prepara un buon fuoco per il mio arrivo,

e invita chi vuoi.

Non osare

informare nessuno

che questi servetti sono furbi.

Se ti chiedessero cosa porti,

di che sono i panni sporchi.

LUCREZIA Va bene

BARABBA Dio ti guidi, mia signora.

LUCREZIA E lui abbia cura di te, mio signore.

BARABBA Contenta va la traditrice

oggi che le ho fatto il favore.

SCALCO Barabba,

non vantarti/gonfiarti, come stai?

BARABBA Digiuno.

SCALCO Per Dio, vile difetto. ${ }^{16}$

Ma, alla fine, non lo sarai,

che la ragazza se ne va allegra.

BARABBA Di piacere,

perché da ieri

avevamo qualche diverbio.

SCALCO Deve essere molto giovane, ora che muta i denti.

BARABBA È di quelle

di cui l'uomo si serve

e vive e fa il fatto suo,

e persino più di quattro donzelle

non sono tali al letto.

Non ridere,

che in queste notti fredde

mi riscalda ${ }^{17}$ un po'.

So bene che col passar dei giorni non ha perso l'appetito.

\footnotetext{
${ }^{15}$ Levar: « lo mismo que llevar . Es voz anticuada», en DA.

${ }^{16}$ Tacha: «Falta, nota, u defecto, que se haya en alguna cosa, y la hace imperfecta. Covarr. dice puede venir del Lat. taxare, que significa también menoscabar», en DA.

${ }^{17}$ Escallentar, escalentar: «lo mismo que calentar. Voz antigua», en DA.
} 
BARABBA

Hai indovinato/ci azzecchi bene.

Come raccontano le mie vicine,

soprattutto la Celestina,

dice che le vecchie galline

fanno buona la cucina.

SCALCO Vieni qua,

tu che già le conosci

e capisci le loro storie, ${ }^{18}$

cercami ora da quelle parti

una di quelle vecchie puttane.

BARABBA Badessa?

SCALCO E anche se fosse priora.

Fai in modo che venga qui

presto $^{19}$ con le tovaglie

mentre mando a prendere il vino.

BARABBA Dì, villano,

non pranziamo prima

che suoni la bacchetta

435

SCALCO Chiamiamo il cuoco

se ha qualcosa da offrirci.

Metreianes!

METREIANES Mon ami?

SCALCO Ho del pane

e una brocca di malvasia.

Hai cercato i fagiani

come ti ha detto Mattia?

METREIANES Acuté:

par ma foi g'i ballaré

chiosa di bon compañón. ${ }^{20}$

BARABBA

Certamente, io so già

che lui avrà giudizio.

SCALCO Fai in modo

di offenderci

con la tua fretta e la nostra spesa.

450

BARABBA Guarda, che tutto il fegato

lo dividi dall'antipasto.

E dunque, attento:

fai una salsa beata

che sia a noi riservata,

e il grasso della pignatta

passalo nella nostra caolata. ${ }^{21}$

METREIANES Farò bene.

SCALCO Non è il caso di pungergli

i calcagni ${ }^{22}$

BARABBA Oh figlio di puttana, ma chi?

SCALCO Giuro per Dio che è un buon compagno.

BARABBA Non vi accorgete?

Le due libbre che gli date

da portare dove ben sapete

\footnotetext{
${ }^{18}$ Conseja: «Cuento, patraña, o fábula que se inventa y dice, algunas veces para sacar de ella alguna moralidad, y las más para diversión y pasatiempo», en DA.

${ }^{19}$ Apriessa, apriesa: « adv. con presteza, brevedad y prontitud. Viene del latino Presto», en DA.

${ }^{20}$ Senta: / per la mia fede, io vi darò / una cosa, da buon compagno.

${ }^{21}$ Caulada. En it. caulo=cavolo, en VLI.

${ }^{22}$ No es menester que le den / del aguijón al calcaño:
} 


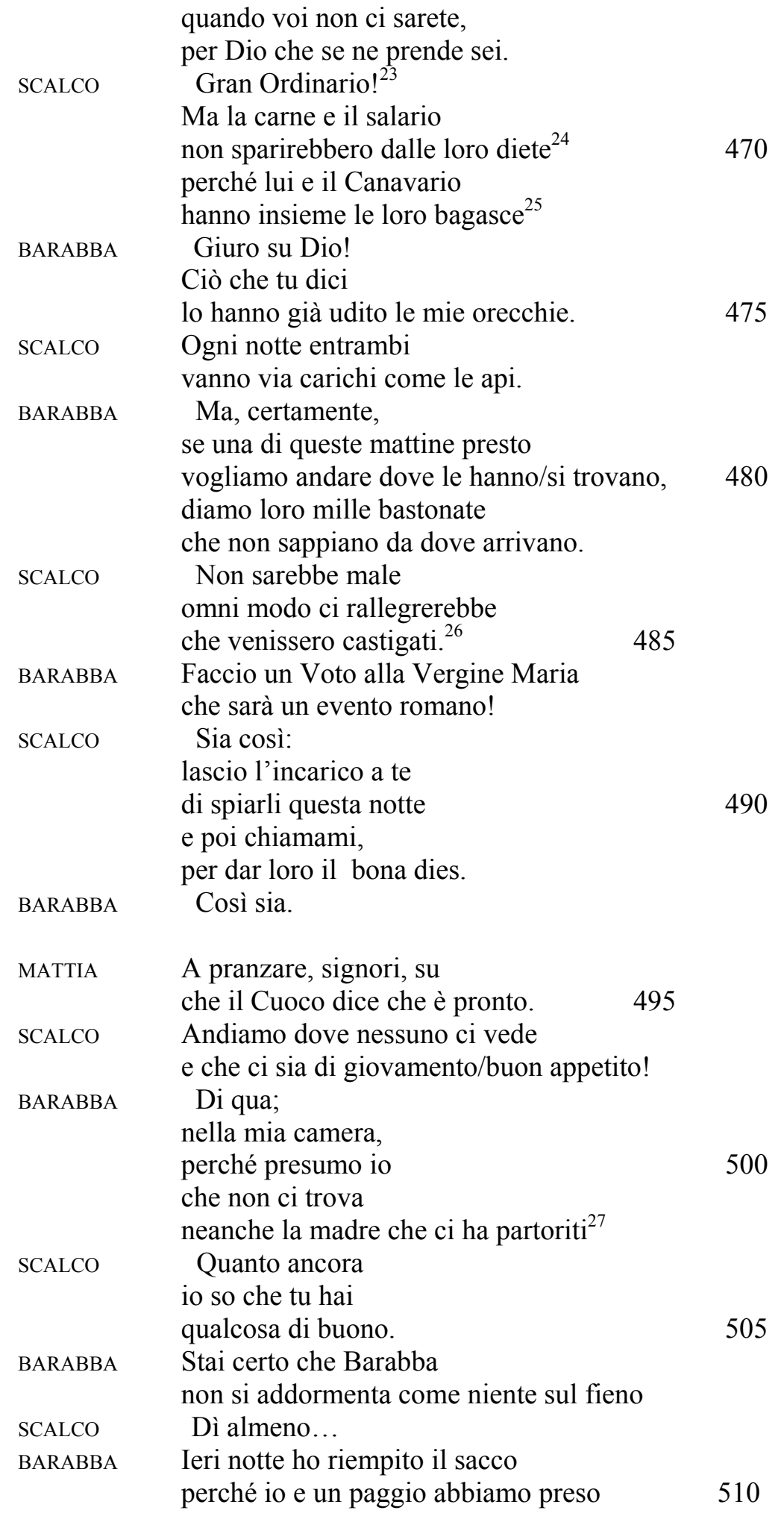

\footnotetext{
${ }^{23}$ Gran Cossario: « en buena parte el que es muy versado y ordinario en ir y venir algún camino, o traginar, y tener trato de alguna cosa», en TLCE; «el ordinario en cualquier oficio: como carretero rosario; vinatero rosario; panadero rosario; panadero rosario», en VR.

${ }^{24}$ Tassa: «Vale también medida, regla, o dieta, que se impone a alguno en la comida, o porte, por enfermedad, o castigo. Lat. Modus. Taxatio», en DA.

${ }^{25}$ Bagassa: «nombre injurioso que se da a las mugeres perdidas y de mal vivir. Trahe esta voz Covarr. y dice que viene de Vagabondo, porque estas mugeres andan siempre vagando y libres. El P. Guadix dice que viene de Bagax Arágibo, que significa engaño. Lat Meretrix», en DA; del italiano bagascia, etim. incierta, en VLI

${ }_{26}^{26}$ (...) holgaría que llevassen una mano. En VR dar una mano corresponde a castigar.

${ }^{27}$ la madre que nos parió.
} 
sette pasticci molto buoni

di cervo e maiale selvaggio.

SCALCO Buon colpo

Ma io te lo rilancio

con una gallinona ${ }^{28}$ gentile.

BARABBA Ma ieri tutti quelli del convito ${ }^{29}$

siamo stati uomini di raccolta? ${ }^{30}$

SCALCO Che vuoi ancora?

Il mio servo consuma piaceri, anche se non è molto astuto,

ieri ha alleggerito un paio di bicchieri

che valgono i loro ducati.

BARABBA Bada, fratello,

che quel giovane è un gran villano,

e dicono, da quel che ho sentito,

che, da tempo, mancano

non so quali piatti d'argento.

SCALCO Stupido!

Non lo sai? Voglio dirlo

che sono voci false,

perché lo stesso credenziere

ne ha fatto sparire alcuni.

MATTIA Che state facendo?

Non so cosa aspettate.

Che ritardo spiritoso!

SCALCO Hai bisogno di noi?

MATTIA Muovetevi,

che quella cosa si raffredda.

SCALCO Fra un po' arriviamo

Se continuiamo a parlare

noi soli perdiamo,

che serviamo e fatichiamo

e non abbiamo guadagno.

Benefici

non si danno per i servizi;

vedo pure, che è così,

che a quelli che hanno mestieri

dovrebbero dare un tanto al mese.

BARABBA Posso dirvi

che ho sentito

alcune nuove, e quali nuove!

che vogliono dare da vestire

a tutti gli ufficiali.

SACALCO È peggio,

cosa dirò a Monsignore

che io mi tiro fuori.

555

BARABBA E perché?

SCALCO

Per il colore,

che si chiama verde speranza.

BARABBA Basta.

\footnotetext{
${ }^{28}$ Somada, Soma : «En la Germanía significa la gallina. Juan Hidalgo en su Vocabulario», en DA.

${ }^{29}$ Combite, del italiano Convito: «Pranzo solenne a cui sono invitate più persone», en VLI.

${ }^{30}$ Levada, del italiano Levare =togliere, portar via= sacar, llevarse; «for levar, llevar (...) was still current in the sixteen century» (Gillet, 1951, III, 474, v. 344).
} 
Io vi dico che Barabba

lo ha saputo da una fonte sicura.

SCALCO Vieni qui, quanto mi darai

d'ora in poi per la mia parte?

BARABBA Come, quanto?

Dieci ducati ti darò,

la metà in castigliani.

SCALCO Prenderò dieci reali

eppure ringrazierò Dio.

MatTIA Giuro su Dio!

Aspettando voi due

la caçuela si è raffreddata.

BARABBA

Vai avanti tu, Scalco,

io e Mattia ti seguiamo.

MATTIA Come così?

BARABBA Vieni qua, tieni da quella parte, mettiamo queste tovaglie.

MATTIA Tu vuoi, per l'anima mia, che arriviamo alle briciole?

BARABBA Non lo faranno,/ Non succederà

ci aspetteranno.

Tira ancora,

MATTIA

Che bene sta.

580

BARABBA

Queste altre.

MATTIA

BARABBA

Quanta fatica!

Ora finiamo, già.

Smettila.

che arriverai in tempo.

Metti lì quelle due saliere.

MATTIA Finisci una volta per tutte, Barabba, che i compagni aspettano.

BARABBA Per l'anima tua, che adesso mi sono ricordato, sono ricomparsi i piatti.

MATTIA

Quali piatti?

BARABBA Non lo so.

I sei che avevi perso?

MATTIA Sì, per Dio.

Gli avevi persi tu

prestandoli a gente vile.

BARABBA Io ne so solo di due che sono a casa di Lucrezia.

MATtia Così stanno le cose,

e il Canavario ne ha altri tre.

Rimedierò con lo stagno.

Quanto guadagno al mese

me lo tolgono a fine anno.

BARABBA Oh, disgraziato,

che mi ero dimenticato

quello che ieri ti avevo promesso!

Che ragazza ti ho trovato

che ti darà fino a qui!

MATtia Non mi dispiace.

BARABBA Bella, dritta e tesa,

certamente graziosa, gentile. 


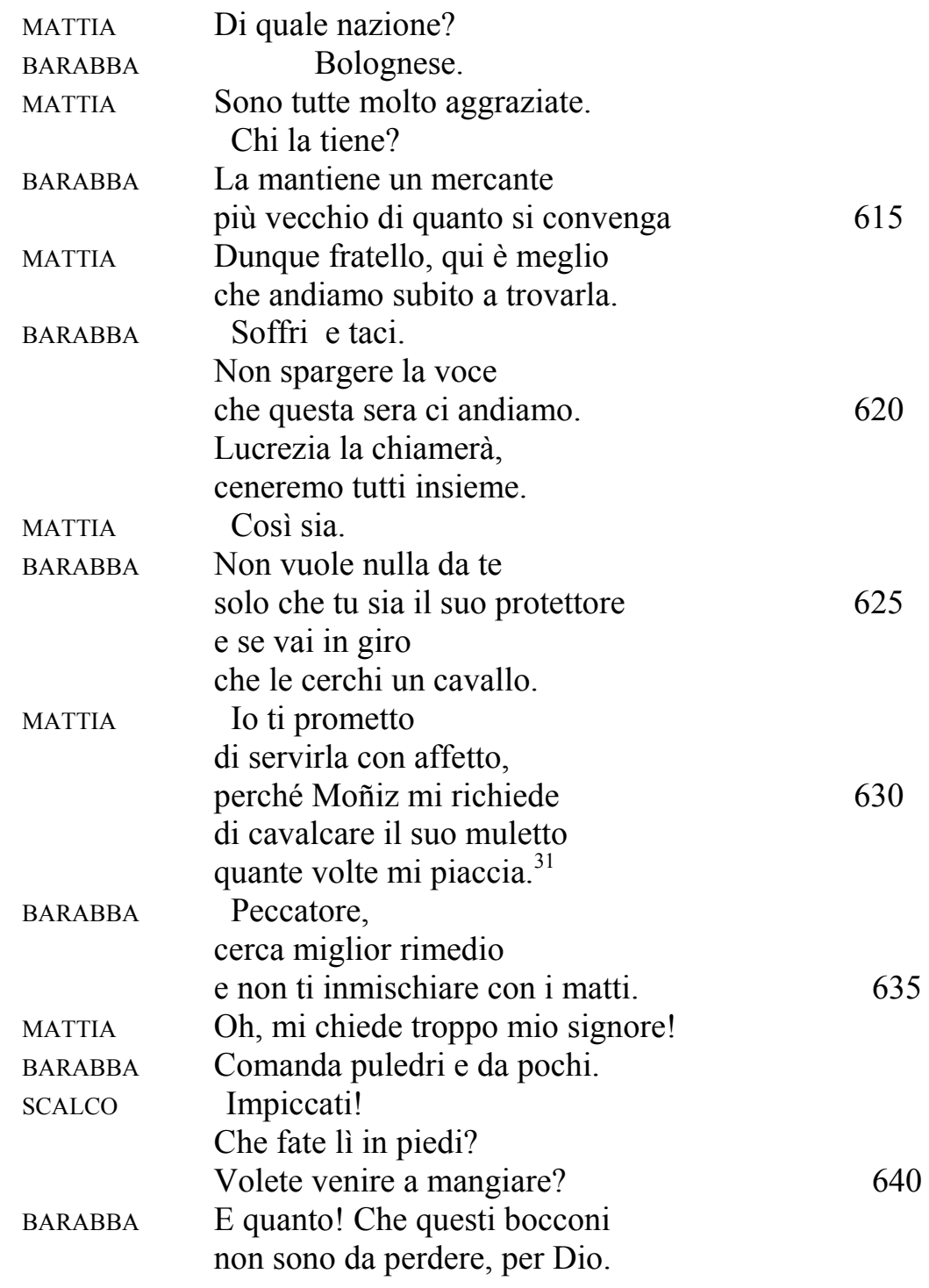

${ }^{31}$ Gillet interpreta a muleto, como mulo pequeño, de poca edad o cerril «Moñiz owned a mule which he probably rode in the train of his master» (Gillet, 1951, III, 476, v. 458). 


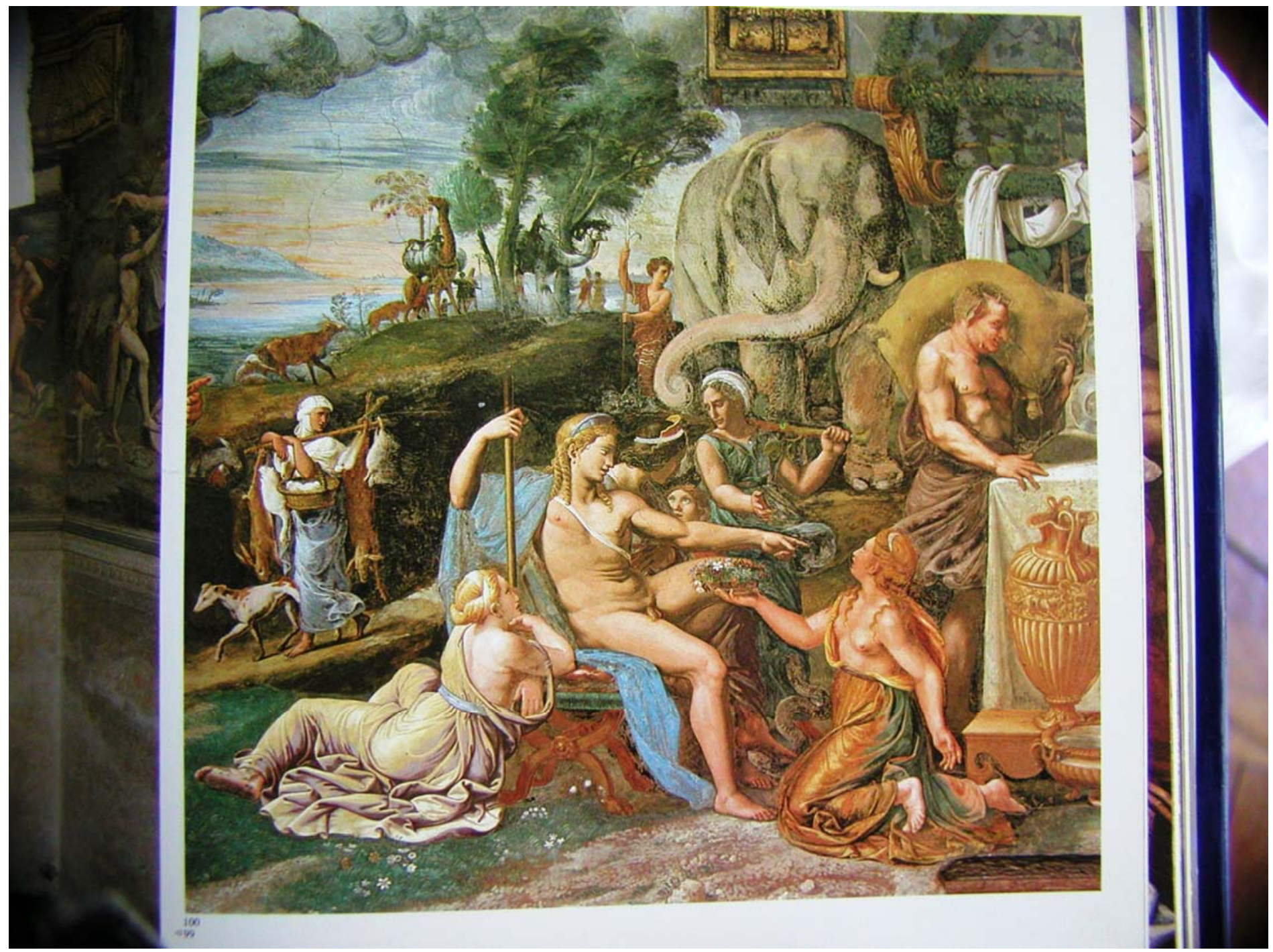

Giulio Romano, particular del banquete nupcial, sala de Psique, Palacio Te, Mantova (1527-1529) 
Barabba, credenziere. Mattia, servo. Francisco, servo. Fabio, servo. Portoghese, servo. Tudesco, servo. Miquel, servo. Biscaglino, servo. Petiján, servo. Scalco. Godoy, scudiere. Moñiz, scudiere. Osorio, scudiere.

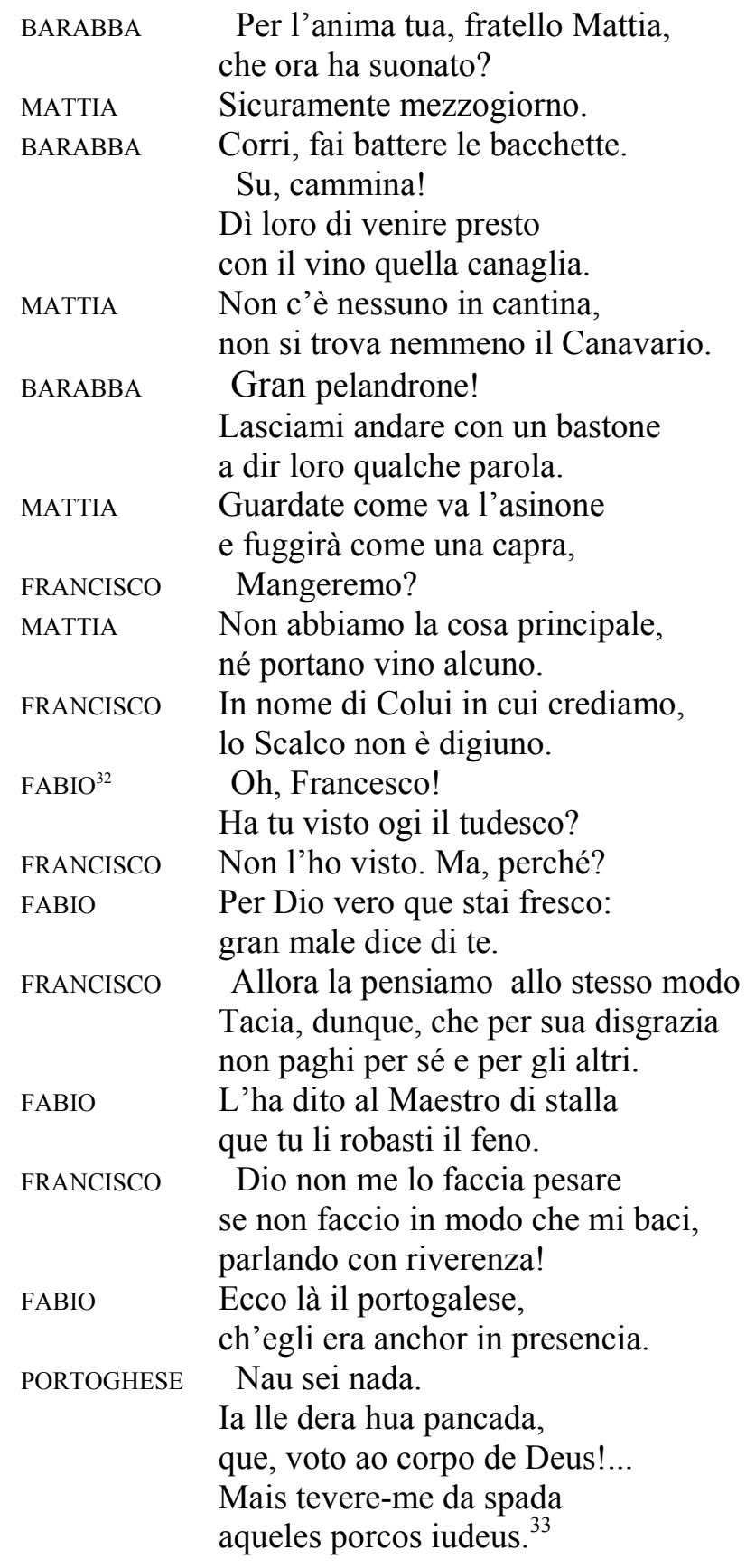

\footnotetext{
${ }^{32}$ En el original Fabio habla en italiano así como lo transcribimos.

${ }^{33} \mathrm{P}$ : Non so nulla.

Io gli darei un colpo,

che, giuro sul corpo di Dio!...

Se non mi prendessero la spada quei sporchi giudei.

T: Io no.

Per Dio!
} 


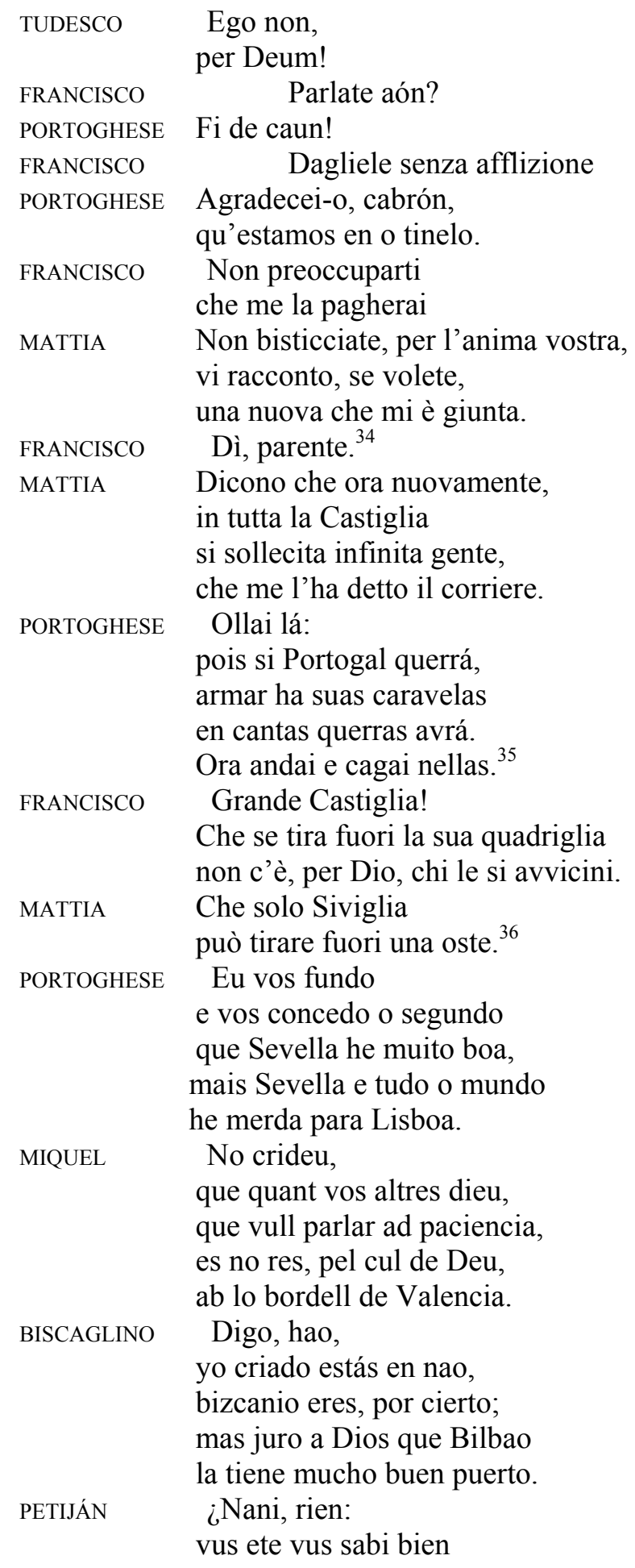

F: Parlate ancora?

P: Figlio di un cane!

F: Dagliele senza afflizione.

P: Ringrazia Dio, cornuto, che siamo nel tinello

${ }^{34}$ Pariente: «En estilo familiar y cortesano se llaman el marido y la mujer», en DA.

${ }^{35}$ P: Guardate lá: se il Portogallo vuole armerà le sue caravelle in tutte le guerre che ci saranno.

Ora, andate a cagare in esse.

${ }^{36}$ Hueste: «(del lat. hostis, enemigo, adversario.) f. Ejército en campaña», en DLE, RA. 
notre studi de París?

FRANCISCO Che mi diano legnate

se capisco quel che dite.

PETIJÁN Mon ami,

per la xar de notre Di,

lo gran Roy y lo Delphín... ${ }^{37}$

FRANCISCO Ora, per amor mio,

che tu scodi ${ }^{38}$ un mastino.

PETIJÁN Gran mersé. ${ }^{39}$

BISCAGLINO Castillanos, a la fe,

la tiene mil raposías. ${ }^{40}$

FRANCISCO Io, per Dio, non ne conosco alcuna.

BISCAGLINO Juro a Dios, sabido avías. ${ }^{41}$

PORTOGHESE Dai cá, irmaons;

eu vos digo que marraons

son, de casta do diabo.

Naun brinquéis con castelaons,

FRANCISCO Una cosa poi è certa

Si finisce a botte

con chi va fuori legge,

e con chi dice che alla sua porta

ha cagato il cavallo del re.

MATTIA Che gente!

${ }^{37}$ P: Sono d'accordo

e ti concedo la seconda,

che Siviglia è molto buona;

ma Siviglia e il mondo intero

è spazzatura comparata con Lisbona.

M: Non urlate,

che tutto quel che voi dite,

voglio discuterlo con pazienza,

non è nulla, per il culo di Dio,

comparato con il bordello di Valenza.

B: Dico, hao,

fui servo in nave,

biscaglino sono per certo;

ma giuro su Dio che Bilbao

ha un porto molto buono

P: No, in nessun modo:

voi conoscete bene

la nostra università di Parigi?

F: Che mi diano legnate se capisco quel che dite.

P: Amico mio, per il nostro Dio incarnato, il grande Re e il Defino

${ }^{38}$ Sorrabar: «Lo mismo que derrabar, o cortar el rabo a algún animal. Es voz antiquada», en DA.

${ }^{39} \mathrm{P}$ : Tante grazie.

${ }^{40}$ Raposías = raposería, de Raposera: «Astucia de zorro y mañas suyas», en DA.

B: I Castigliani, per l'anima possiedono mille astuzie.

${ }^{41}$ B: Giuro su Dio, che le conosci.

${ }^{42} \mathrm{P}$ : Di là in qua, fratelli; io vi dico che i marrani sono, della razza del diavolo. Non giocate con castigliani, perché portano la coda lunga. 


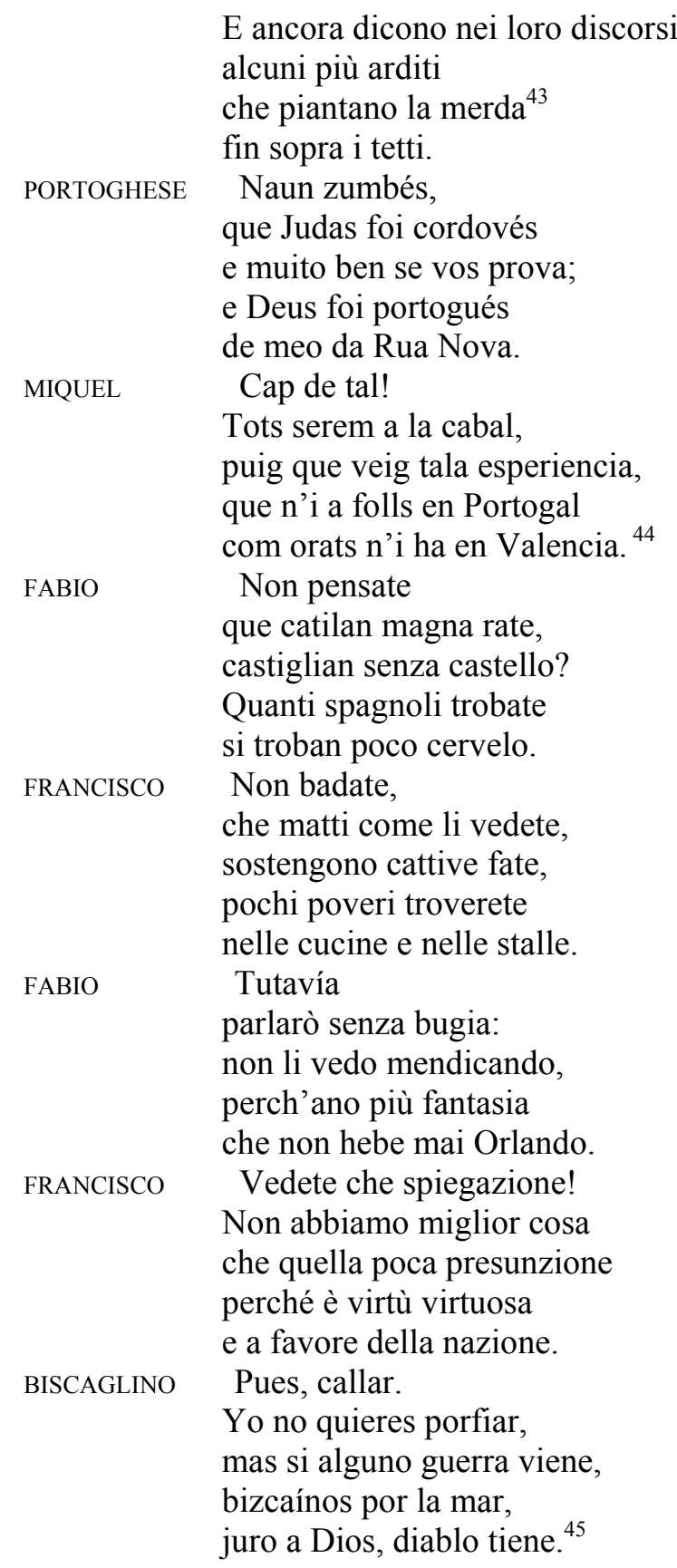

${ }^{43}$ que chantava os cagallones / por enriba dos tellados: «Cf, Reynosa, ap. Gallardo, Ensayo, IV, 1406 (...). Cf. Salaya, Farsa, 1. 1092 f. Chanto (chantar is the archaic plantar, fincar) muytos cagallones / por mita de os tellados, (...)»» (Gillet, 1951, III, 481, v.108).

${ }^{44}$ P: Non burlarti, perché Giuda fu di Cordoba, e molto bene vi si dimostra; e Dio fu portoghese, di in mezzo alla Rua Nova.

M: Corpo di un tale! Tutti dobbiamo renderci conto, come vedo, ci sono tanti matti in Portogallo come dementi a Valenza.

${ }^{45} \mathrm{~B}$ : Dunque tacete. Non voglio ostinarmi, ma se arriva qualche guerra, i biscaglini in mare, giuro su Dio, sono come il diavolo. 


\begin{tabular}{|c|c|}
\hline FABIO & $\begin{array}{l}\text { Certamente, } \\
\text { buzcaíno l'è valente, } \\
\text { ¡al corpo de Jesuchristo! }\end{array}$ \\
\hline FRANCISCO & $\begin{array}{l}\text { So che state guardando della gente } \\
\text { che tale non avete mai visto. }\end{array}$ \\
\hline FABIO & Dici bene. ${ }^{46}$ \\
\hline FRANCISCO & $\begin{array}{l}\text { Però vi faccio sapere che, } \\
\text { quando partirà il nostro esercito, } \\
\text { attraverso l'Italia dove siete } \\
\text { trascinerà molta gente. }\end{array}$ \\
\hline FABIO & $\begin{array}{l}\text { Puis, irmano, } \\
\text { ¿per qués cosas restirano } \\
\text { istas gentes que dieazís? }\end{array}$ \\
\hline FRANCISCO & $\begin{array}{l}\text { Qui e lì, di mano in mano, } \\
\text { proteggeranno tutto il paese. }\end{array}$ \\
\hline SCALCO & $\begin{array}{l}\text { Che cosa state facendo? } \\
\text { Sapete che non mi piace } \\
\text { che facciate qui taverna? }\end{array}$ \\
\hline & $\begin{array}{l}\text { Se sperate che vi minacci, } \\
\text { vi ricorderete di me. }\end{array}$ \\
\hline GODOY & $\begin{array}{l}\text { Che rumore! } \\
\text { Buon giorno, mio signore. }\end{array}$ \\
\hline SCALCO & Ben venuto sua mercé. \\
\hline GODOY & $\begin{array}{l}\text { Potete farmi un favore, } \\
\text { che sono morto di sete? }\end{array}$ \\
\hline SCALCO & $\begin{array}{l}\text { Con piacere, } \\
\text { se il vino fosse arrivato. }\end{array}$ \\
\hline MOÑIZ & Buon giorno, cavalieri. \\
\hline GODOY & $\begin{array}{l}\text { Oh, come siete aggraziato! }{ }^{48} \\
\text { Che ora stesso muoiano i barbieri. }\end{array}$ \\
\hline MOÑIZ & $\begin{array}{l}\text { Dite bene. } \\
\text { Scalco, mi fate } \\
\text { una grandissima grazia? }\end{array}$ \\
\hline & $\begin{array}{l}\text { Uccidete il mio servo } \\
\text { e non dategli contumacia. }{ }^{49}\end{array}$ \\
\hline FRANCISCO & $\begin{array}{l}\text { Come sarebbe? } \\
\text { Per non darmi un po' del grosso } \\
\text { devo mangiare in osteria? }\end{array}$ \\
\hline MOÑIZ & Vigliacco, sì, lo confesso. \\
\hline FRANCISCO & Oh che gentile cortesia! \\
\hline MOÑIZ & $\begin{array}{l}\text { Cosa credi? } \\
\text { Che per le tue vigliaccherie } \\
\text { devo rimetterci io? }\end{array}$ \\
\hline FRANCISCO & $\begin{array}{l}\text { Signore, mai per colpa mia, } \\
\text { siete arrivati fino a qui. }\end{array}$ \\
\hline
\end{tabular}

\footnotetext{
${ }^{46}$ Bien digáis. Fabio, ahora habla en castellano.

${ }^{47}$ Dunque, fratello, per chi rimarrà qui questa gente che tu dici?

${ }^{48}$ Polido=pulido «(Del lat. politus): Agraciado y de buen parecer, pulcro, primoroso», en DA.

${ }^{49}$ Dar contumacia: «Frase familiar, con que se esplica que a algún convidado le dejaron sin comer, no queriendo aguardarle, porque tardó en venir a la hora regular: lo que se suele usar con frecuencia en las Universidades entre los Estudiantes, que están alojados a patio», en DA.

(...) y no le deis contumacia: «It here meas a penalty, by wich the servant will be prevented from having his meals in the tinelo, his master being obliged to pay for them elsewhere» (Gillet, 1951, III, 486,v. 179).
} 


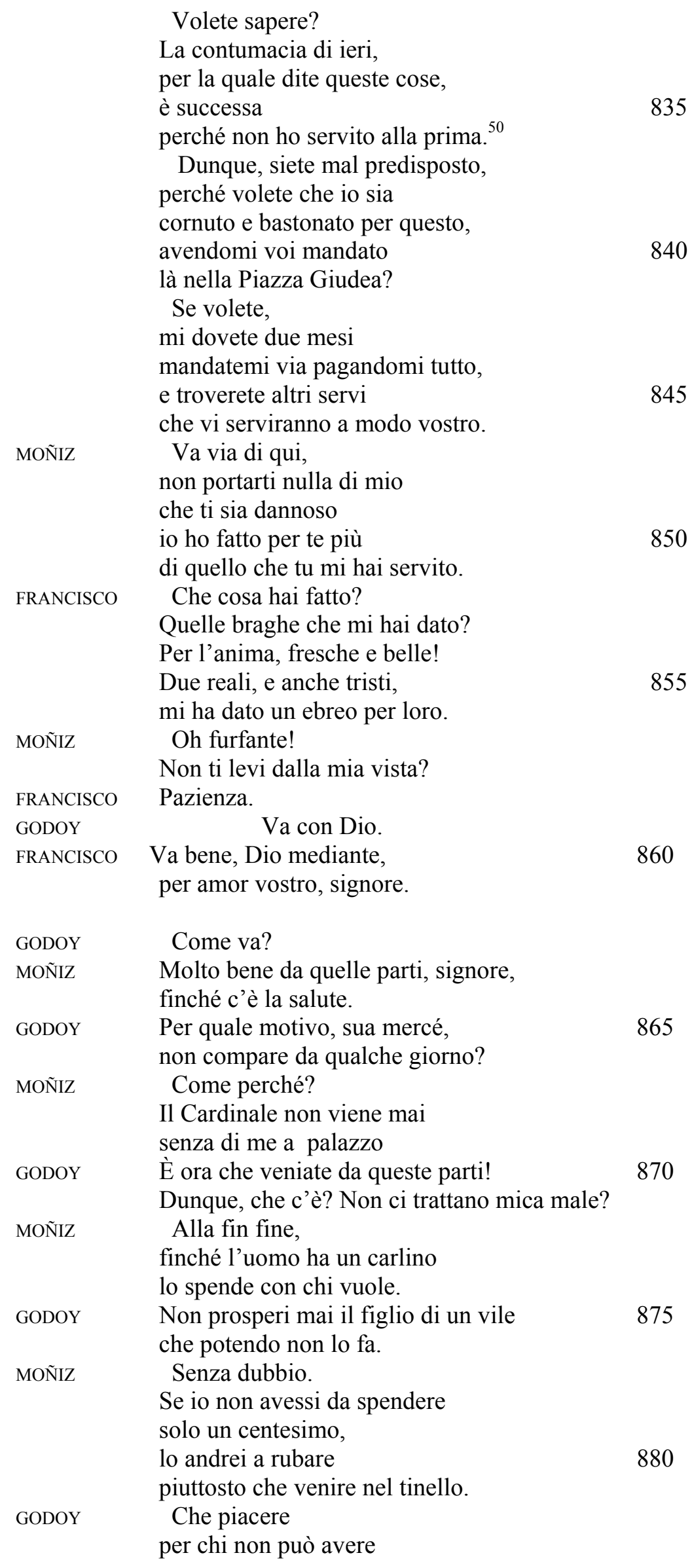

50 «That is a la primera mesa» (Gillet, 1951, III, 486, v.194). 


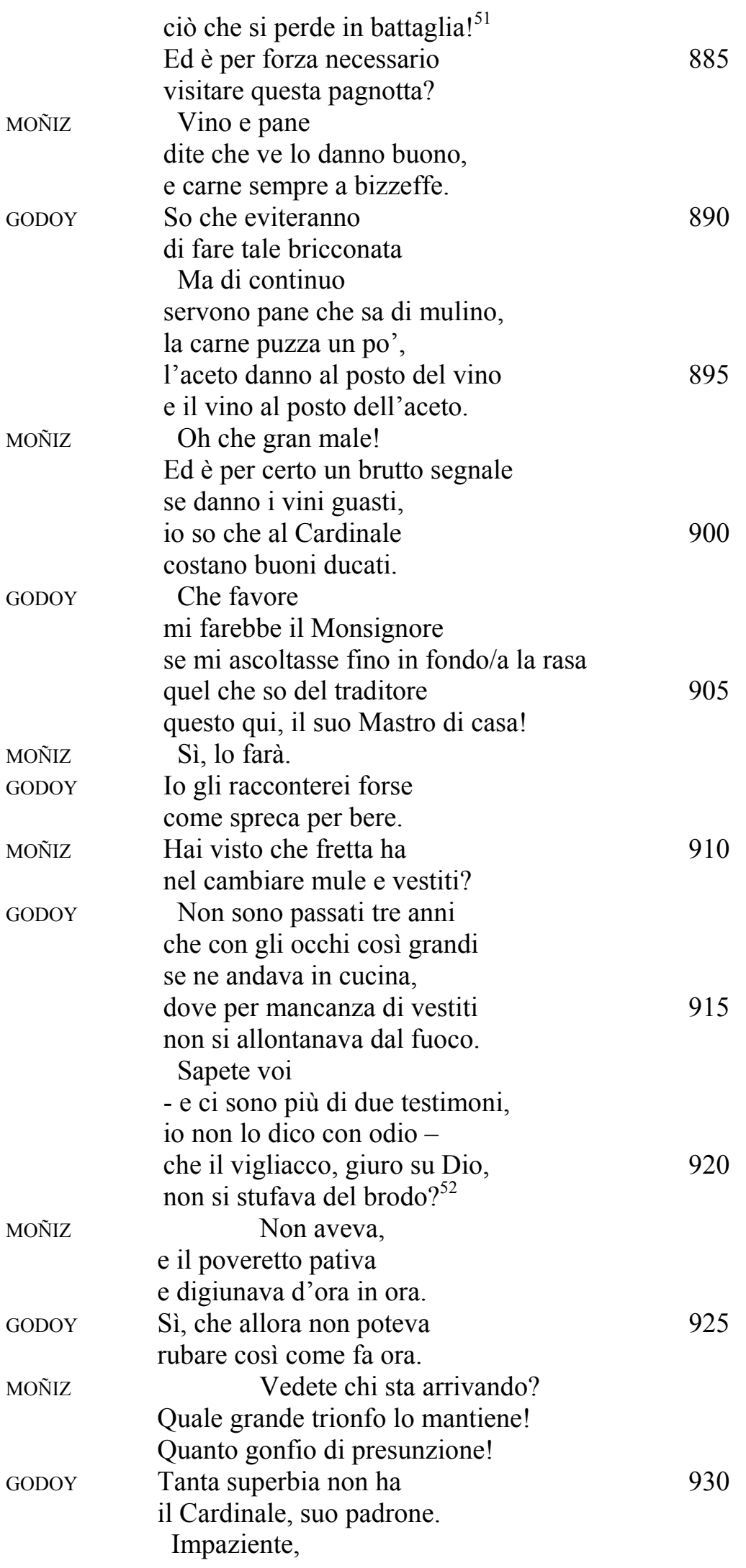

\footnotetext{
${ }^{51}$ iQué plazer / para quien no puede aver / quanto se dexa en la rota!: «Godoy continues to taunt the formerly affluent and uppish Moñiz: ¿Qué plazer debe ser [el acudir al tinelo] para quien no [siempre] puede disponer de cuantas riquezas se abandonaron en la rota» (Gillet, 1951, III, 486, v. 240).

Rota: 1. «Rompimiento del ejercito o tropa contraria, desbaratandola en batalla, y deshaciéndola», 2. «Lo mismo que Derrota», 3. «Tribunal de la Corte Romana», en DA.

${ }^{52}$ Brodio: «El caldo con algunos trozos de legumbres y sobras de la olla, que de ordinario se da a los pobres en las porterías de los monasterios y otras comunidades. Viene del italiano brodo, que significa caldo», en DA.
} 
senza amore e maldicente

tiranno di cattiva grazia,

diligente solo

a darvi contumacia.

MOÑIZ

GODOY

MOÑIZ

GODOY

MOÑIZ

OSORIO

GODOY

OSORIO

GODOY

OSORIO

MOÑIZ

GODOY

OSORIO

GODOY
Fareste bene

a non dire queste cose.

Suvvia, che non gli voglio male,

ma vedo, come vedete anche voi

che fa vergognare il nostro padrone;

vediamo bene

che tratta male

solo noi che possediamo poco

perché non possiamo

parlare così al Cardinale.

Le sue passioni

vanno tutte secondo simpatia,

se il Cardinale non rimedia,

ad alcuni da tre razioni

e agli altri non ne da né mezza.

Dai, fratello,

che il villano se ne andrà,

non durerà a lungo.

Diamogli poi una mano,

e il Cardinale si divertirà

Paroline!

Qui dite meraviglie,

e giuro su Dio e questa croce

che se lo vedete a quattro miglia

cominciate ad adularlo. ${ }^{53}$

che, giuro su Dio vero,

non mi tolgo mai la berretta

se lui non lo fa per primo.

Che siano delle buone abbazie

e, se no, non le vogliamo.

Scusate,

a dire il vero

vorrei rassicurarvi

Rassicuri tale volontà

dove possiate curarvi.

No, signore.

So che vi accertereste meglio

con quella vostra ragazza.

Dicono che siete un gran faccendiere.

980

\footnotetext{
${ }^{53} \mathrm{Buz}$ : «Cierto gesto halagueño hecho con los labios, o los hocicos: los quales porque se llaman buces dieron lugar a esta dicción, de la cual sólo se usa con el verco hacer, y se llama hacer el buz, mostrar un género de rendimiento, o una afect5ación estudiosa de agradar, con algún modo de adulación», en DA.

${ }^{54}(. .$.$) porque dais lexos del hito$
} 
Ma sappiate che si dice,

e si afferma con forza,

che la vostra Maddalena

OSORIO

ice che siete impotente.

Sì, per Dio,

già mi pregano più di due,

e posso mostrarvele.

MOÑIZ Tacete, peccatore,

che quelle stanno per spellarvi.

OSORIO Oh fortuna!

Dunque voi sapete anche di una

che porto in giro.

MOÑIZ Non c'è casa in cui entrate

che non vi prendano per incapace.

OSORIO Lo avete visto?

MONIZ Senza che me l'aveste detto

so che ormai sanno in tutta la Castiglia

che la pensione che avete venduto

se l'è mangiata Catalnilla

Peccatore!

Davvero, fareste meglio

a risparmiare per cose piccole

e servire il Monsignore

1005

OSORIO

che andare dietro alle gonnelle delle puttane.

Che difetti!

Altri girano più assoggettati

e dietro ad esse più attenti.

GODOY

Imitate i discreti

e non seguite i viziosi.

OSORIO Tutto è buono.

MOÑIZ La donna è un dolce veleno, quando è cattiva ancora di più, ed è come il fuoco nel seno e nella sottana il serpente.

OSORIO Salomone,

Davide ed il forte Sansone

per amore sono stati imprigionati.

MOÑIZ

Oh, che lodevole ragione!

Ditemi che ci hanno guadagnato:

lo stesso di voi.

GODOY Io intervengo contro voi due, che il giusto mezzo è amarle, ma Dio non ci manda

OSORIO a perderci con loro. Secondo me, amando bisogna perdere molte volte la pelle/la faccia, perché chi ci dice di amare

MOÑIZ non ci dice di seguire consigli.

I beni se ne vanno dietro quei piaceri, ed è contro Dio e coscienza.

OSORIO Finché Dio ci da le donne

GODOY Hai ragione.

Passiamo ad un'altra questione: 


\begin{tabular}{|c|c|c|}
\hline \multirow[t]{2}{*}{ OSORIO } & $\begin{array}{l}\text { quella cosa vostra è stata spedita? } \\
\text { La maledetta supplica? }\end{array}$ & \multirow[t]{2}{*}{1040} \\
\hline & Giuro su Dio che non è partita. & \\
\hline MOÑIZ & Ed è presto. & \\
\hline OSORIO & $\begin{array}{l}\text { Finché l'avrò in mano } \\
\text { mi farà mal di stomaco. }\end{array}$ & \\
\hline \multirow[t]{2}{*}{ GODOY } & $\begin{array}{l}\text { Dunque, pregate Dio, fratello, } \\
\text { che Giovanni Vincle non la trovi. } \\
\text { E con tutto ciò, } \\
\text { è in pericolo omni modo, } \\
\text { perché mi fa pensare }\end{array}$ & 1045 \\
\hline & $\begin{array}{l}\text { che andrà in fumo } \\
\text { la riserva di Sorrento. }{ }^{56}\end{array}$ & 1055 \\
\hline \multirow[t]{2}{*}{ OSORIO } & $\begin{array}{l}\text { Non ho paura, } \\
\text { che sono un suo gran servitore; } \\
\text { e se non basta la mia preghiera }\end{array}$ & \\
\hline & $\begin{array}{l}\text { c'è lì l'ambasciatore, } \\
\text { che mi darà poi il suo consenso. }\end{array}$ & 1055 \\
\hline GODOY & Spedito? & \\
\hline \multirow[t]{2}{*}{ OSORIO } & $\begin{array}{l}\text { Sì, mi ha già richiesto } \\
\text { con il fatto che, se voglio una cappa }\end{array}$ & \\
\hline & $\begin{array}{l}\text { e ancora se voglio un altro beneficio } \\
\text { mi sistemerà con il Papa. }\end{array}$ & 1060 \\
\hline \multirow[t]{3}{*}{ MOÑIZ } & $\begin{array}{l}\text { Cosa farei, } \\
\text { se avessi tale spinta! }\end{array}$ & \\
\hline & $\begin{array}{l}\text { Ti giuro su Dio, fratello, } \\
\text { non starei più un giorno }\end{array}$ & 1065 \\
\hline & con Monsignore del Baccano. & \\
\hline OSORIO & $\begin{array}{l}\text { Non parlare così; } \\
\text { che il Monsignore, se guardi bene, } \\
\text { sarà papa senz'altro. }\end{array}$ & \\
\hline GODOY & $\begin{array}{l}\text { A questo punto non partire, } \\
\text { così avrai un confessionario. }\end{array}$ & 1070 \\
\hline \multirow[t]{2}{*}{ OSORIO } & Io ho fiducia. & \\
\hline & $\begin{array}{l}\text { Più del suo destino/scelta } \\
\text { un giorno mi ha rivelato, } \\
\text { che un astrologo ebreo }\end{array}$ & 1075 \\
\hline \multirow[t]{3}{*}{ GODOY } & Hai visto? & \\
\hline & È la regola generale & \\
\hline & $\begin{array}{l}\text { che tutti pensino alla propria cappa: } \\
\text { il vescovo a diventare cardinale } \\
\text { e il cardinale papa. }\end{array}$ & 1080 \\
\hline \multirow[t]{2}{*}{ OSORIO } & Come no? & \\
\hline & $\begin{array}{l}\text { Perché anche io penso } \\
\text { di diventare il vescovo della mia terra. }\end{array}$ & \\
\hline GODOY & $\begin{array}{l}\text { Pensando di vincere, morì } \\
\text { mio padre, andando in guerra. } \\
\text { A mio avviso }\end{array}$ & 1085 \\
\hline
\end{tabular}

\footnotetext{
${ }_{55}^{55}$ ¿La negra suplicación?: «was evidently a request for a benefice» (Gillet, 1951, III, 490, v. 403).

56 (...) que os ha de poner del lodo / la reserva de Sorrento: «Sorrento is probably the Cardinal (Francisco Remolino) referred to in Sold. I, 219 (q.v.), or it might refer to the town. The 'Crusca' (1735) defines riserba, riserva as termine de' canonisti, e vale determinazione, che i benefici non si debbano conferire da altri, che dal Papa. Apparently a papal Bull, executed in due form by the Curia, was necessary for conferring benefits under reserva (...)» (Gillet, 1951, 491, v. 408).
} 
il pensare non è sapere

né il sognare è profezia,

chiediamo da mangiare,

che è un'altra mercanzia.

MOÑIZ Cattiva gente,

che fanno sempre in modo

da doverli aspettare.

FRANCISCO Lo Scalco e altri venti

1095 si stanno ubriacando.

MOÑIZ

Dove, dì?

FRANCISCO Gli ho visti, ora

nella stanza del Cuoco

MOÑIZ Signori, seguitemi,

GODOY Non facciamo tardi.

E vogliamo anche la nostra parte,

che ci tocca di diritto,

oppure faremo in modo

1105

che non abbiano una buona digestione. 


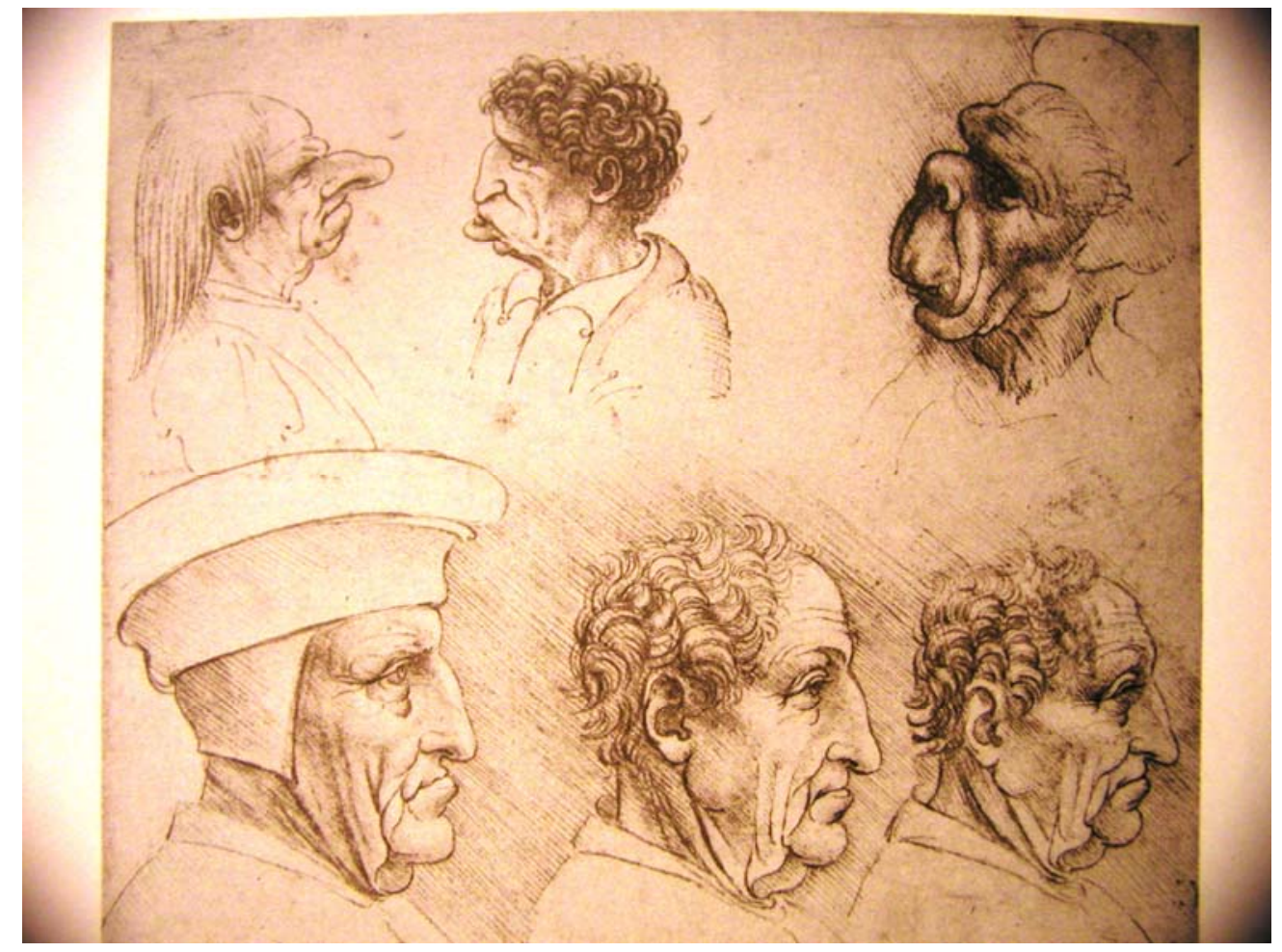

Leonardo da Vinci, Expresiones grotescas, Colección de Windsor Royal Library, 1480-1481 
Scalco. Mattia. Godoy. Osorio. Moñiz. Biscaglino. Francisco. Miquel.

Tudesco. Staffiere. Decano.

SCALCO Signori, su a mangiare.

Entrate quelli che avete da entrare

e, fattemi il piacere,

ognuno al suo posto.

1110

$\mathrm{Su}$, fratelli,

perché siete con le mani incrociate

senza benedirvi?

GODOY Cominciate da questa parte, villani;

ogni giorno sapete di meno.

1115

SCALCO Vedrete

che ora, per grazia di Dio,

non ci sarà nessun cappellano.

MATTIA Là fuori ce ne erano due.

GODOY Io sono mezzo sagrestano.

Se è necessario,

1120.

io farò la benedizione,

che la so dalla culla.

SCALCO Dilla, alla fin fine

sarà meglio che nulla.

GODOY Benediamo

colui che tutti adoriamo,

perché ci protegga dal male,

e chi ci da dà mangiare

ch'è il signor Cardinale.

Io benedico

il pane e il vino, come dico,

e tutti gli altri materiali,

e violentemente maledico

gli inservienti traditori.

Per primo,

maledico il Cuoco,

che fa la minestra magra,

e poi il Dispensiere,

che compra muli per manzi.

Malediamo,

per il vino cattivo che beviamo,

il fannullone del Canavario,

e lo Scalco, perché vediamo

ci succhia l'ordinario.

1125

Dunque, signori,

Dio ci faccia i suoi favori

e ci presti le sue orecchie,

e ci liberi dai traditori,

dai litigi e dalle vecchie puttane.

SCALCO Oh galante!

Passate avanti, signori, ognuno al suo posto. 
MOÑIZ

OSORIO

GODOY

OSORIO

GODOY

SCALCO

GODOY

SCALCO

GODOY

SCALCO

OSORIO

GODOY

MOÑIZ

GODOY

MOÑIZ

SCALCO

OSORIO

GODOY
Sua mercé non si spaventi, che ha da sedersi qui.

Cavaliere,

so già che passate voi per primo,

ne siamo tutti certi,

ma io sono cameriere.

Suvvia, che siete extra mura.

1160

Giuro su Dio!

Scalco, ditelo voi

per tirarci fuori da questa baruffa. ${ }^{57}$

Dopo aver bisticciato

vi ricordate del mestiere?

1165

Fantasie!

Giuro sulla Vergine Maria

che, anche se ciò a qualcuno pesa,

io mi siederò ogni giorno

a capo tavola.

Che per il bene

non so chi mi porterà

a guadagnare sul Ponte Sisto,

ma per male e disdegno,

Giuro su Dio, se fosse Cristo!...

1175

Per favore,

sedetevi ora, signore,

che dopo avrò il modo

di chiedere a Monsignore

che mi dia la lista di tutti.

1180

Venga il pane.

Con quale grazia lo daranno!

Prendi il piatto, scemo.

Scalco, ci danno pane cattivo.

Prendetevela con il fornaio.

1185

Che risposta!

Avete visto che fatica fa ora

a parlare bene, perché agisce male.

Questo lo danno per le feste,

di solito non è così.

1190

Senza canzoni,

scommettiamo i capponi

che il servo mi ha portato ieri,

che il vigliacco e i suoi ladri

non mangiano se non pane scadente.

Che dubbi!

Fareste meglio a tacere,

che ci portano l'antipasto.

Cominciate a servire di là

due a due come sono disposti

1200

Ho assaggiato.

Sembra che è salato

e ancora sa un po' di fumo.

Giuro che è affumicato!

Che sia sgozzato il Cuoco.

Che cosa guardate?

Invito nella mia dimora

\footnotetext{
${ }^{57}$ Bollicio=bullicio: «Lo mismo que tumulto y bullicio. Es voz anticuada», en DA.
} 
quanti di voi sedete a tavola,

se mi date soltanto

un trancio di fegato.

SCALCO Rapace, su,

dai il vino da quella parte

fai in modo di essere discreto.

OSORIO Se lo Scalco comanda, beviamo, che ne abbiamo motivo.

1215

FRANCESCO Allora, arriva

da queste parti?

Che moriamo di sete.

SCALCO

Silenzio, che sta arrivando.

FRANCESCO Bordone vostra mercé.

OSORIO Non vale niente.

MOÑIZ Che dite? Non vi piace?

Non sapete che cosa è buono; giuro su Dio che per l'insalata, vale un peso d'oro.

GODOY Anche se così fosse!

Mandiamo a prendere una brocca alla prima taverna.

MOÑIZ Attenti che costa un reale.

GODOY Che costi anche un ducato se vuole.

SCALCO Per piacere;

non fate tanto rumore;

per Dio, che mi meraviglio.

GODOY Scalco, fareste meglio

a prestarci un servo.

SCALCO Perché?

GODOY Perché vada dove io gli dirò per fermare una rissa.

SCALCO Scusate, per l'anima vostra, che non posso aprire la porta.

GODOY Oh gran morte!

ci hai dato il vino così forte che non possiamo gustarlo, né vogliono, per disgrazia, che l'uomo mandi a comprarlo.

OSORIO

Gran villano!

Darei tutto quello che guadagno, senza risparmiarmi nulla, pur di rompergli con la mia mano la bacchetta sulla testa.

MOÑIZ

Lo penso anche io.

Seguite ora me e cerchiamo di aver pazienza, non siamo venuti qui a far altro che penitenza.

SCALCO

Su Mattia,

portate le minestre.

OSORIO Datemi una che sia grassa.

MOÑIZ Anche io la vorrei.

SCALCO Tutte lo sono in abbondanza.

GODOY Scommettiamo che questo singolare brodo è acqua con erbette, 


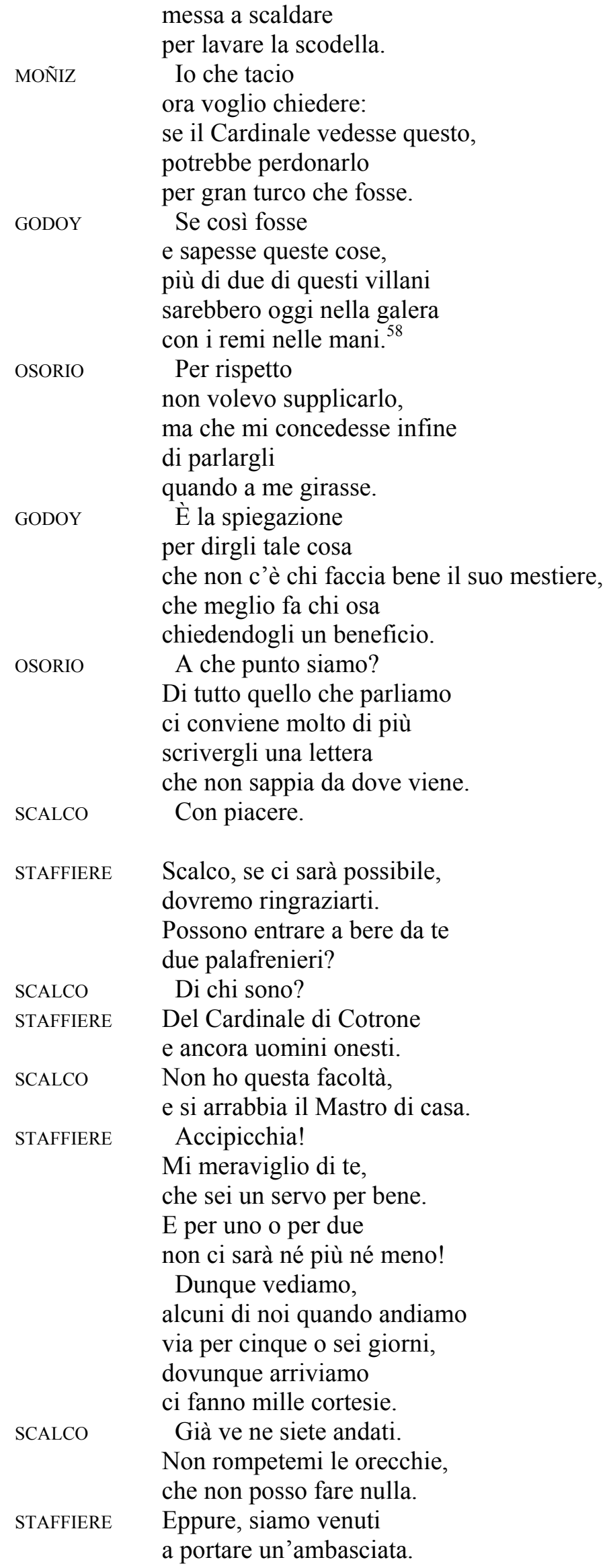

${ }^{58}$ Con los remos en las manos: «Pena de remar en las galeras», DLE, RA. 


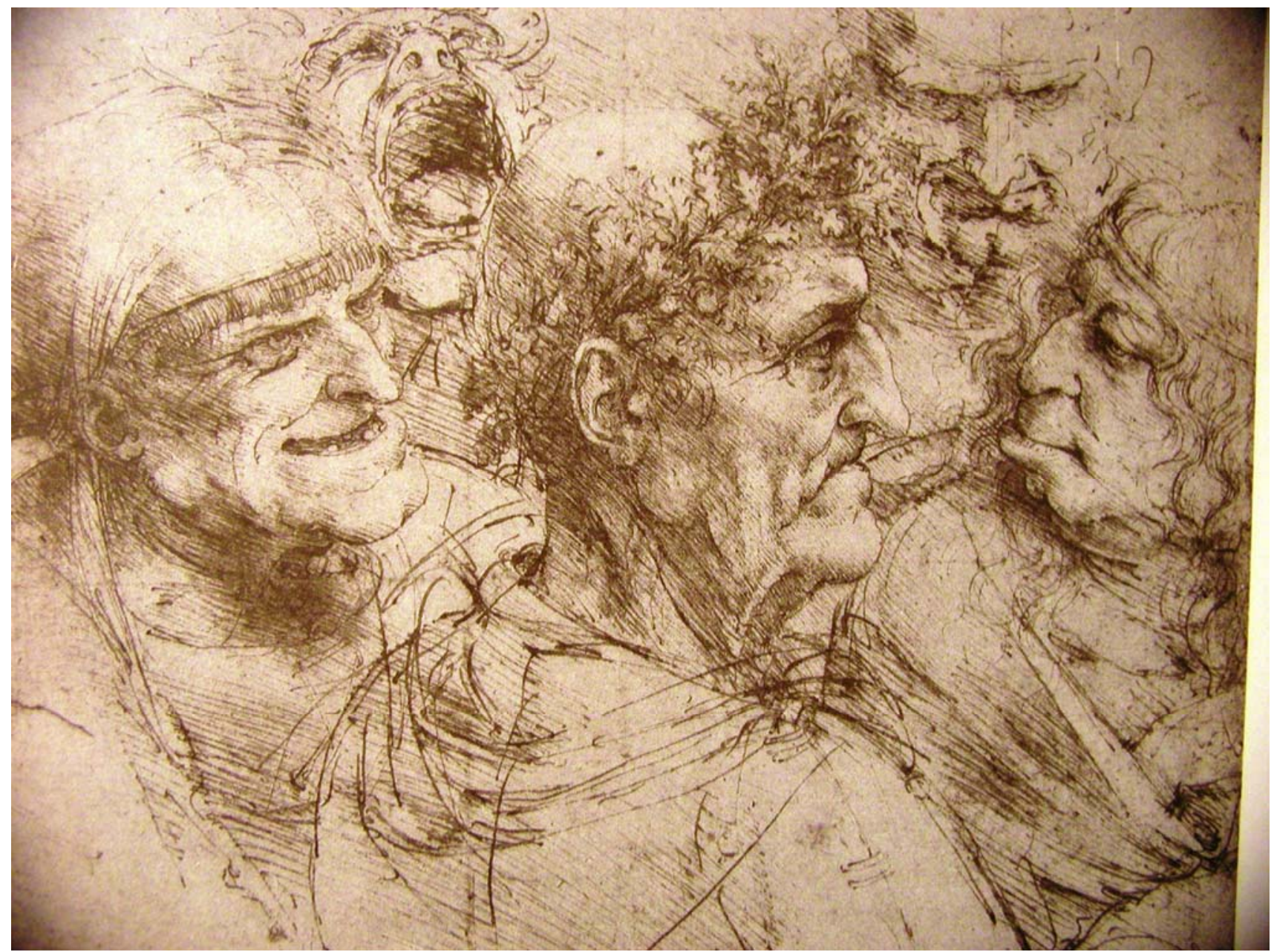

Leonardo da Vinci, Expresiones grotescas, Colección de Windsor Royal Library, 1480-1481 
Se guardi bene

si tratta dell'onore di Monsignore

e quello che tu gli rubbi

è una cosa ben peggiore.

SCALCO Sii cortese una volta, due e tre, e fammi il piacere.

STAFFIERE Vorrei più un centesimo di quanto tu puoi fare.

Comunque, vuoi che il tuo male non esca dalla mia bocca?

Lo dirò al Cardinale

la prima volta che cavalcherà.

Basta!

$\mathrm{Su}$, presto Barabba, la carne è già tagliata?

Perché non la porti?

OSORIO Dovrebbe essere già servita.

SCALCO Dunque, divertirvi?

Questo è il modo che avete di fare i bravi

MOÑIZ Giuro che ora lo minaccia!

GODOY Che dite, vogliamo mandare

a prendere un quattrino di mostarda?

MOÑIZ

Che spiritoso!

Lo Scalco fa il grazioso

per fare cortesia.

GODOY L'altro va contento,

là vedete la sua compagnia.

DECANO Non urliamo.

Scalco, tutti abbiamo

le nostre scuse

tu dici che non facciamo altro

che portare degli invitati.

Sii più sobrio,

che segui il camino errato,

sai che sei così meschino

che da te non ricordo

aver mai avuto un bicchiere di vino.

SCALCO Con le tue parole,

non pensare che mi spaventi

anche se venite in quadriglia

a fare i prepotenti nel tinello

mentre mangia la famiglia.

Fai male;

e se continui a fare

in questo modo con me,

lo dirò al Cardinale

e avrai alla fine il castigo che ti meriti. 
Chi ha mai sentito

$\mathrm{e}$ in quale tinello si è visto

che un villano qualunque

tratti male uno Scalco come me

del Cardinale del Baccano?

DECANO Non sprecarti,

che mentendo mi stai rispondendo.

SCALCO Guarda quanta paura mi hai fatto prendere?

Per l'anima, fareste meglio

a vendicare quello che vi hanno dato.

MOÑIZ

È possibile

che l'uomo possa mangiare

una carne di manzo così dura?

Lasciatela almeno cuocere bene

perché è pelosa.

GODOY Che gustosa!

Non ho mai visto una cosa così cattiva, né voi avete visto, se vi ricordate,

una carne così maliziosa

che senza mangiarla si è già stufi.

1380

Cavaliere,

MOÑIZ

perché non ci danno montone

o a volte anche vitello?

SCALCO La compra il dispensiere, ma la danno ai malati.

MOÑIZ Giustamente,

per consolazione.

Non li trattano bene?

BISCAGLINO Signore, ha detto il padrone

di mandarmi con la sua parte.

SCALCO Si, per Dio;

sembra che sono qui

a fare il servo di tutti.

Digli, per amor mio,

che la chieda al Cardinale.

1385

1390

BISCAGLINO No has quesido.
SCALCO Digli quello che hai

1405

SCALCO Digli quello che hai sentito.

Giuro che sta fresco.

FRANCISCO Vedi, signore, come ha nascosto

la carne quel tedesco?

1400

Ego non,

per Deum vivum. ${ }^{59}$

SCALCO Scansafatiche!

MIQUEL Io hu he vist, seynor, y tot. ${ }^{60}$

FRANCISCO Nella manica del giubbetto

TUDESCO Nite carne, yo, bi Got. ${ }^{61}$

FRANCISCO Per la mia vita,

è caduta sul tavolo.

SCALCO Non ho mai visto più bella grazia.

Veni foras. ${ }^{62}$

${ }^{59}$ Io no, / per Dio vivo.

${ }^{60}$ Io l'ho visto, signore, e tutto.

${ }^{61}$ Carne no, sì, per Dio. (Yo etc. ja, en Mc Pheeters, 1979, 147)

${ }^{62}$ Vai fuori 


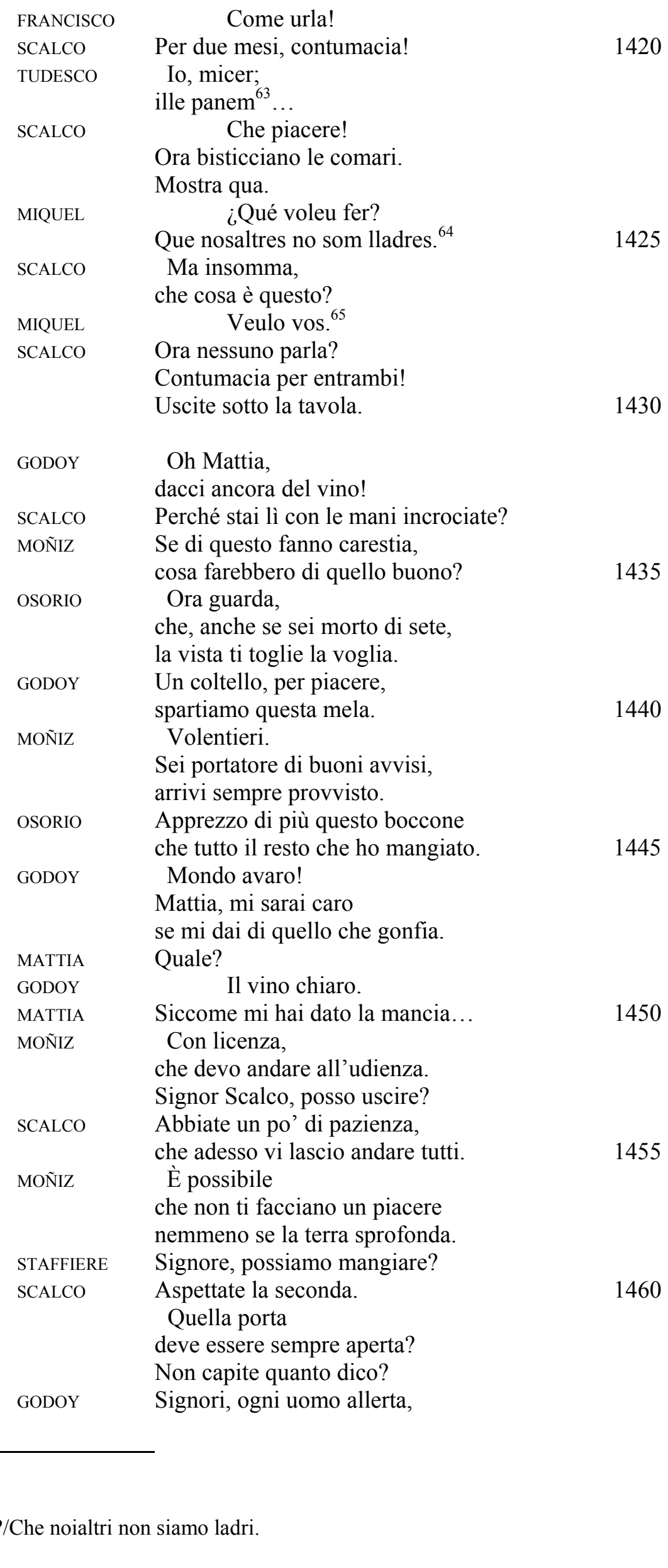

\footnotetext{
${ }^{63}$ Sì, signore; quel pane

${ }^{64}$ Che volete fare?/Che noialtri non siamo ladri.

${ }^{65}$ Vedi tu.
} 
non le porta con sé.

MOÑIZ Che scansafatiche!

Quanto ha guadagnato in presunzione

da quando ha cambiato puttana! $!^{66}$

GODOY Qui fa il leone

e per strada è una pecora.

OSORIO Ha tutto.

GODOY Sta arrivando il Mastro di casa.

SCALCO Porta il saliere, ragazzo.

MOÑIZ Per Dio, ci conviene stare zitti, perché conosciamo le sue furie.

OSORIO Sii discreto, attento che parlano in segreto.

MOÑIZ Che Dio porti loro un cattivo anno.

GODOY Certamente, perché, io vi prometto

che nessun bene del compagno...

MOÑIZ Scommettiamo

che ci manda a cavalcare?

E giuro sulla mia vita

che andiamo ad accompagnare

la sua puttana che oggi è morta.

OSORIO Dio sia con voi!

1485

Non dite nulla.

SCALCO A tutti, domini mei:

alle venti si cavalca. ${ }^{67}$

Non mancate, amore Dei.

1490

GODOY Dunque vediamo,

non sarà meglio sapere

dove andiamo, per crederci?

SCALCO Dicono che andiamo a accompagnare

l'ambasciatore di Guinea.

$\begin{array}{ll}\text { GODOY Non è pagano? } & \text { Sì̀ ma viene a diventare cristiano. }\end{array}$

GODOY Chi lo battezzerà?

SCALCO Il Papa ha già predisposto

un dottore che lo farà.

GODOY Faranno bene.

SCALCO Fermati, ragazzo, porta il pane.

FRANCESCO Abbiate gli occhi ben aperti.

SCALCO Chi è quel giovane?

Uno di quelli impiccati?

1505

FRANCESCO No signore.

SCALCO Per amore o per timore

non si castiga nessuno.

FRANCESCO Che uccidano come traditore

chi non gli da un fico.

1500

SCALCO Vieni qui.

Su Mattia, porta via il vino.

FRANCESCO Questa sì che è una cattiva notizia,

Dio gli porti sempre male.

MATTIA

C'è qualcuno che beve ancora?

\footnotetext{
${ }^{66}$ Pelleja: 1. «La piel quitada del cuerpo del animal: specialmente de las ovejas u carneros»; 2. «Volgarmente se da este nombre, como afrentoso, a la mujer de mal vivir, o ramera», en DA.

${ }^{67}$ «Cuatro horas antes de puesto el sol montamos a caballo (veáse Soldatesca, n.35)», en Mc Pheeters, $1979,149$.
} 


\begin{tabular}{|c|c|}
\hline GODOY & $\begin{array}{l}\text { No, amico, } \\
\text { piuttosto c'è chi si pente } \\
\text { di aver bevuto un vino così cattivo }\end{array}$ \\
\hline MOÑIZ & Io sì, voglio una sputacchiera. \\
\hline \multirow[t]{4}{*}{ SCALCO } & $\begin{array}{l}\text { Signori, dunque... quasi mi dimentico: } \\
\text { arrabbiato }\end{array}$ \\
\hline & $\begin{array}{l}\text { oggi Monsignore mi ha chiamato } \\
\text { e mi ha detto con la sua bocca } \\
\text { che tutti, di grado in grado, } \\
\text { facciate la guardia che vi tocca. } \\
\text { Chi peccasse }\end{array}$ \\
\hline & e mancasse una prima volta \\
\hline & $\begin{array}{l}\text { per un mese non mangerà un boccone; } \\
\text { la seconda volta, se necessario, } \\
\text { verrà licenziato. }\end{array}$ \\
\hline \multirow[t]{2}{*}{ GODOY } & Giuro su Dio! \\
\hline & $\begin{array}{l}\text { Sempre lasciate più di due } \\
\text { fuori dalla lista }\end{array}$ \\
\hline SCALCO & $\begin{array}{l}\text { Fate quel che vi tocca } \\
\text { del resto non immischiatevi. }\end{array}$ \\
\hline \multirow[t]{7}{*}{ GODOY } & Come no? \\
\hline & Figlio di puttana, \\
\hline & Con che cosa vieni fuori? \\
\hline & $\begin{array}{l}\text { Sono più gentiluomini di me, } \\
\text { o figli del grande Sufi? }\end{array}$ \\
\hline & Di solito, \\
\hline & $\begin{array}{l}\text { con quelli tacete, } \\
\text { anche se mancano per un mese o cento } \\
\text { e accusi gli altri }\end{array}$ \\
\hline & anche se mancano un momento. \\
\hline \multirow[t]{4}{*}{ SCALCO } & Che ti succede oggi? \\
\hline & Almeno a te non porto \\
\hline & molestie né dispiaceri; \\
\hline & $\begin{array}{l}\text { perché io e te, signor Godoy, } \\
\text { siamo soliti essere amici. }\end{array}$ \\
\hline \multirow[t]{5}{*}{ GODOY } & Sì, è vero; \\
\hline & ma l'amicizia non impedisce \\
\hline & che l'uomo dica quel che sente. \\
\hline & Sai che la uguaglianza \\
\hline & la lodano Dio e la gente. \\
\hline \multirow[t]{2}{*}{ SCALCO } & E fra di noi \\
\hline & l'hai vista venire meno? \\
\hline GODOY & $\begin{array}{l}\text { Non più di quello che dico, } \\
\text { perché alcuni sono figli di Dio } \\
\text { e altri del diavolo. }\end{array}$ \\
\hline \multirow[t]{3}{*}{ SCALCO } & Allora \\
\hline & che il Cardinale dia a te \\
\hline & la direzione della casa. \\
\hline GODOY & $\begin{array}{l}\text { Non sarebbe male, } \\
\text { ma io non lo accetterei. }\end{array}$ \\
\hline \multirow[t]{3}{*}{ SCALCO } & Che dici! \\
\hline & Guarda che sei presuntuoso, \\
\hline & lo vede anche un cieco ( che lo vuoi). \\
\hline \multirow[t]{2}{*}{ GODOY } & Così non posso vivere. \\
\hline & Volete che viva fra i fuochi? \\
\hline MOÑIZ & Fai bene, \\
\hline
\end{tabular}


di tante attenzioni/responsabilità

è bene che l'uomo si guardi.

GODOY Il Monsignore mi ha pregato.

SCALCO Su, proficiat, che è molto tardi.

È una grande fatica

non avere oggi un cappellano!

MOÑIZ Dio non ce lo faccia avere mai.

SCALCO Un'altra volta ne troveremo

di più che ne abbiamo bisogno.

MOÑIZ Senza passione,

1580

dirò la mia benedizione,

che è breve e compendiosa.

SCALCO Hai ragione.

GODOY Oggi ci tocca anche questa.

MOÑIZ Benediamo

1585

il buon tempo che passiamo

intorno a Campo dei Fiori

e al poco che pensiamo

a servire il Monsignore.

Per ciò

benedico il Santo Natale,

che danno la torta così grande,

maledico il vile servitore

perché chiede la mancia.

Con amore

benedico quel uditore

che ha sentenziato per me,

maledico con grande dolore

la mancia che gli diedi

E inoltre.

benedico al Maestro Bramante

che ha iniziato San Pietro,

maledico quella baccante

che quel traditore mi portò via.

1605

$E$ in fine fine,

benedico il Maestro Pasquino

che si allontana da questa fatica,

maledico solo il quattrino

che nella mia borsa troveranno.

Buona gente,

quel Dio onnipotente

ci faccia suoi eredi,

e ci dia continuamente

salute pace e denari.

1590

1595

1600

SCALCO Giuro su Dio,

siete andati bene tutti e due.

MOÑIZ Sappiate che siamo Mendoças.

GODOY Dove andremo?

MOÑIZ Dillo tu.

GODOY A trovare due paia di ragazze. 


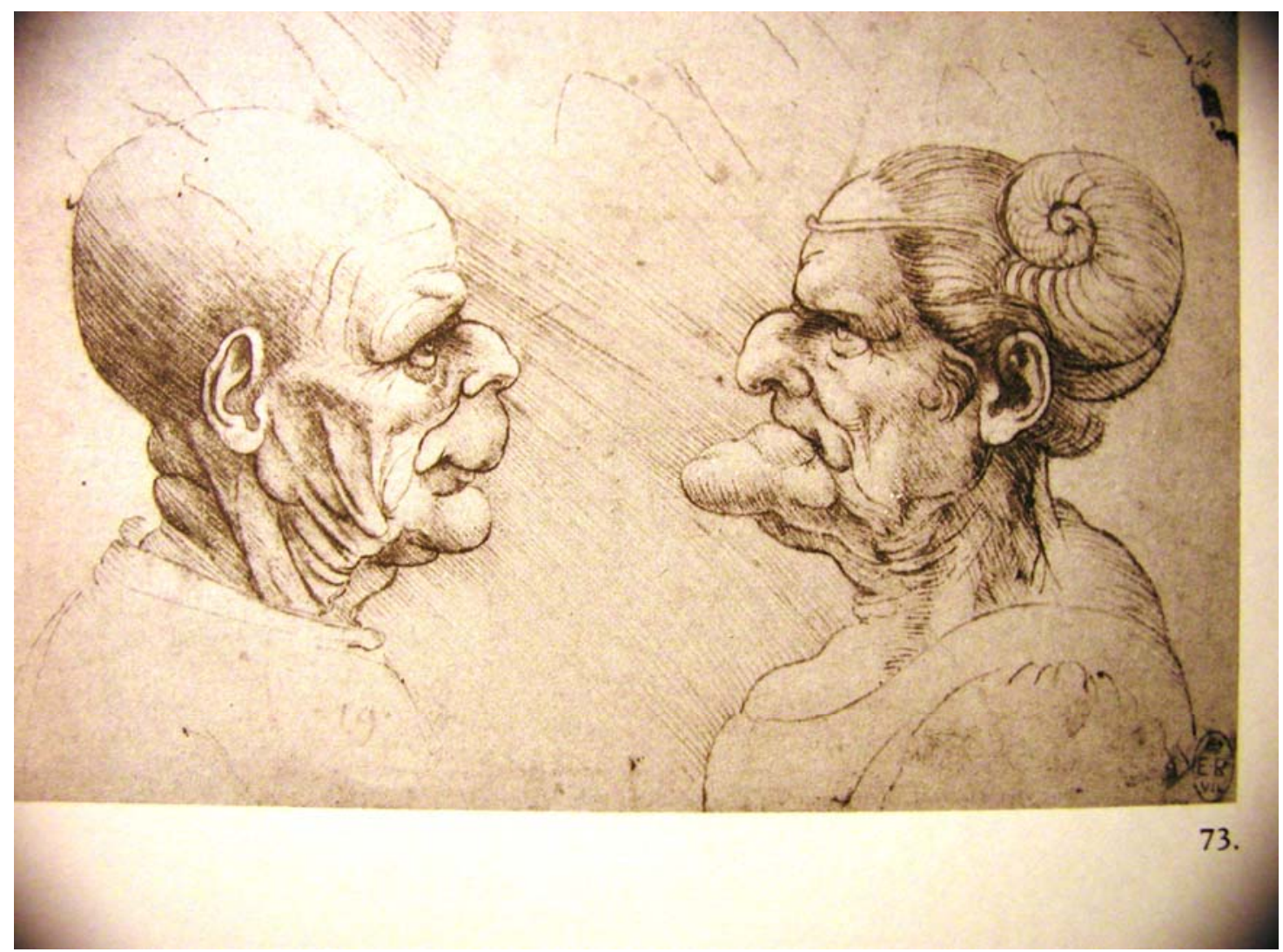

Leonardo da Vinci, Expresiones grotescas, Colección de Windsor Royal Library, 1480-1481 


\section{QUARTA GIORNATA}

Dispensiere. Mastro casa. Osorio. Moñiz. Godoy. Macchiato.

Trombetta.

DISPENSIERE Non si può continuare

a subire una vita così penosa.

Non si può vivere

con questo Mastro del nulla!

Non c'è pazienza che tenga

con un uomo così imprudente,

che di fatto vuole sempre

incolpare la mia coscienza

e prendersi lui i meriti.

Io muoio.

1630

Povero me, dispensiere, sono dieci anni o forse di più che non raggiungo nemmeno un centinaio di ducati!

Che cosa ci ho guadagnato?

Alcune case dove ho lavorato, vestiti in poca quantità, avrei dovuto comprare una buona scrittoria.

A piacere

oggi potrei avere

mille ducati in mano.

Che bisogno ha di questi denari

il Cardinale del Baccano?

Sorvoliamo,

che se il diavolo si divertisse

io vivrei come un papa.

Oh traditore, se non giocasse,

quanto varrebbe oggi la mia cappa!

MASTRO DI CASA Compratore

o Dispensiere Maggiore,

che cosa stai rimuginando?

Di rubare al Monsignore

e di non partire con me?

DISPENSIERE Io vorrei

che adottasse altri modi

per burlarsi di questo povero uomo,

perché sua signoria

è stato sempre ben servito da me.

MASTRO Sì, per Dio.

Don ladro, non ricordi

che avevamo accordato insieme

di rubare tutti e due

e poi partire fraternamente?

DISPENSIERE Così è

MASTRO E allora, dì, perché sei così scortese

e mi fai questo affronto,

sai che da più di un mese 
non mi rendi conto di nulla?

DISPENSIERE Non c'è di che.

MASTRO Come no? Io già so

che ci sono stati quattro mercati,

dove hai guadagnato, in buona fede,

quattro paia di ducati.

DISPENSIERE Ma no,

1675

perché il qui presente mi ha fregato. ${ }^{68}$

MASTRO Perdinci, indovini bene.

Solo è rimasto un mercato

in cui non hai comprato galline.

Se guardi bene,

gli altri tre gli hai ben goduti

in quello che tu saprai,

e sempre uova hai guadagnato

quanto sai e qualcosa in più

DISPENSIERE Che cosa va raccontando!

Non siamo rimasti che,

per meglio gonfiare la trippa,

avremmo rubato alla pari,

io al Mercato e tu nella Ripa ${ }^{69}$

MASTRO

È vero,

1690

ma per partire poi

come amici, senza inganno.

DISPENSIERE Più guadagni tu in un mese

che non io in un anno.

1695

E neanche tanto guadagno con te

perché ti metto alla mia tavola:

vuoi essere uguale a me

nel guadagno e non nella spesa.

DISPENSIERE Sai bene che

la rendita che tu hai

ti solleva da ogni preoccupazione,

e oggi o domani avrai

in carica un vescovato.

MASTRO

Basta.

1705

Facciamo i conti, se vorrai,

e smettiamola;

oppure, sai già

che posso licenziarti.

DISPENSIERE Ancora

io farò questa cortesia,

anche se mi costa caro,

di dare a sua signoria

per una veste.

MASTRO Non so nulla;

1715

più rubi nell'insalata,

che prendi nei cortili

e conti ogni volta

al meno due reali.

DISPENSIERE Perché

${ }^{68}$ qu'el presente me estorvó: «That is, probably: que el Escalco, aquí presente, me impidió la sisa» (Gillet, 1951, III, 511, v. 56)

${ }^{69}$ «La Ripa era un districo de mala fama, donde había huertos» en Mc Pheeters $(1979,157)$. 
non ci sentano urlare

per una cosa civile,

dico che voglio darla

per una mula gentile.

OSORIO Ah, signore!

1725

MASTRO Che vi manda?

OSORIO Per l'amor mio,

vedete che ce n'è motivo,

concedetemi il favore

di non farmi dormire nella locanda.

MASTRO

Posso dirvi che

1730

cerco di servirvi

ma dubito, la prima richiesta,

che non vogliate ridurvi

a stare con un compagno.

OSORIO Buon avviso!

1735

Non sarei accompagnato

se fossi figlio di Dio.

MASTRO Il Cardinale mi ha detto

di mettervi in coppia.

OSORIO Molto bene.

1740

A volte si usa stare

anche in tre,

ma tu sei scortese

e sistemi chi piace a te.

MASTRO Fino a questo punto

non potete mentire su di me

che abbia fatto le cose male,

io sistemo da solo

chi mi manda il Cardinale.

OSORIO

D'accordo;

ma io conosco un fianco [dell'edificio]

dove stanno da soli da tempo, ${ }^{70}$

che il Cardinale non lo comanda

e questi non valgono la mia scarpa.

MASTRO

Se è così,

1755

Per la vostra fede, non addentratevi

in un passaggio così stretto;

lo vogliate o meno,

io faccio così, ed è ben fatto.

Dio lo vuole.
Ma se l'uomo non muore

senza che gli mettano fretta,

ciò che un giorno io farò

sarà pure ben fatto.

MASTRO Per esempio, cosa?

Pensi che mi spaventerò

perché tu mi minacci?

Fammi, per l'anima tua,

il peggio che puoi.

OSORIO

Il vostro vizio

vi farà così male

${ }^{70}$ « El sentido es "Pero yo sé un lado [del edificio] donde están solos desde hace timepo". Osorio quiete una habitación sin compañero», en Mc Pheeters, 1979, 158, nota 35. 
che perderete la presunzione;

il Cardinale da il lavoro,

ma non la discrezione:

Dove si aggrappa

chi lavora senza ordine

poco durano i suoi affanni,

e con il tempo e con la paglia

i peri maturano.

E confido ancora,

secondo il mio giudizio,

che non durano a lungo

né le case vicino al fiume

né gli uomini vili negli incarichi.

MASTRO

Non badare,

che io ti farò parlare

con più cervello e sbagliando meno.

OSORIO Per l'anima mia,

faresti meglio

a trovarti un cane.

MASTRO

Va bene.

1790

MOÑIZ

Che si fa da queste parti?

MASTRO Passiamo la vita cantando.

MOÑIZ Sua mercé mi permette

di dirle due questioni.

MASTRO

Anche duecento.

MOÑIZ

Cerchiamo grandi rendite,

e saremo grandi signori.

MASTRO Lasciamo ora questi conti, non vogliamo fare i migliori.

MOÑIZ Pertanto, andiamo male.

1800

Perché non sono cardinale?

Certamente, saprei bene,

così bene come tanti,

fare quei palleggi.

MASTRO

I ducati,

1805

benefici e vescovati,

è bene saperli dare,

che le bestie e il bestiame

si sanno palleggiare.

MOÑIZ

Voglia il cielo,

che del tutto mi dia almeno qualcosa.

Ma quando, nonostante il diavolo,

verrà il mio ragazzo nel tinello

e il mio cavallo nella stalla?

MASTRO Se vogliamo,

credo che presto possiamo

trovar rimedio per il cavallo,

ma per quanto riguarda il ragazzo

non possiamo che accettarne mezzo.

MOÑIZ

Che ragionamento

per un uomo così saggio

stanco di reggere bene!

Ma è forse il mio ragazzo un melone

che lo dovete tagliare a metà?

MASTRO Non litighiamo,

non è cosa da uomini 
perdere le staffe.

Vedete che i poveri scudieri

hanno abbastanza due in uno.

MOÑIZ

Secondo me,

non possono mangiare insieme

due cavalli litigiosi

e ancora si dice che non è possibile

che un servo lavori per due signori.

MASTRO Ben si può.

1835

Ma viene messo sulla bilancia

chi fa altrimenti,

che chi introduce nuovi usi

viene molto giudicato.

Perciò,

essendo il vecchio uso tale,

chiunque sia buono si consola ${ }^{71}$,

si sa che il Cardinale

non vuole pregiudicare la corte.

MOÑIZ Come sarebbe?

1845

Siccome un vile prima applicava

una usanza vile, come si dice,

perché allora non rischierebbe

un uomo buono di applicarne una buona?

GODOY A che punto siete?

1850

Dunque, se parlate con me,

certamente non vi farà male.

MASTRO Parla bene, ascoltatelo;

chi sa può predicare. ${ }^{72}$

GODOY Andate con Dio.

1855

Vuoi tu ora conoscere

questa usanza così ben pensata?

Ma che rimanga fra noi due.

MOÑIZ

Ci danneggia?

GODOY

Non ci avvantaggia.

MOÑIZ Allora taci.

1860

GODOY Signore, devi sapere,

che, tra due, sicuramente si da

un servetto e

una stanza vuota.

E inoltre,

se mangi nel tinello

fai una vita molto sana,

hai il tuo pasto

tre volte alla settimana.

Così è

che mancando questi tre

già si fa e diventa possibile,

ma pagarvi dopo

questo lo do come impossibile.

Di continuo

1875

vi danno le uova perugine,

\footnotetext{
${ }^{71}$ Se conorte, conhorte, de v. conhortar: «Lo mismo que confortar, consolar y animar. Ya tiene poco uso», en DA

${ }^{72}$ Quien las sabe las tañe: « Refr. que explica, que los Maestros en qualquier arte son los que pueden dar voto; y no los que no las tratan ni profesan», en DA.
} 


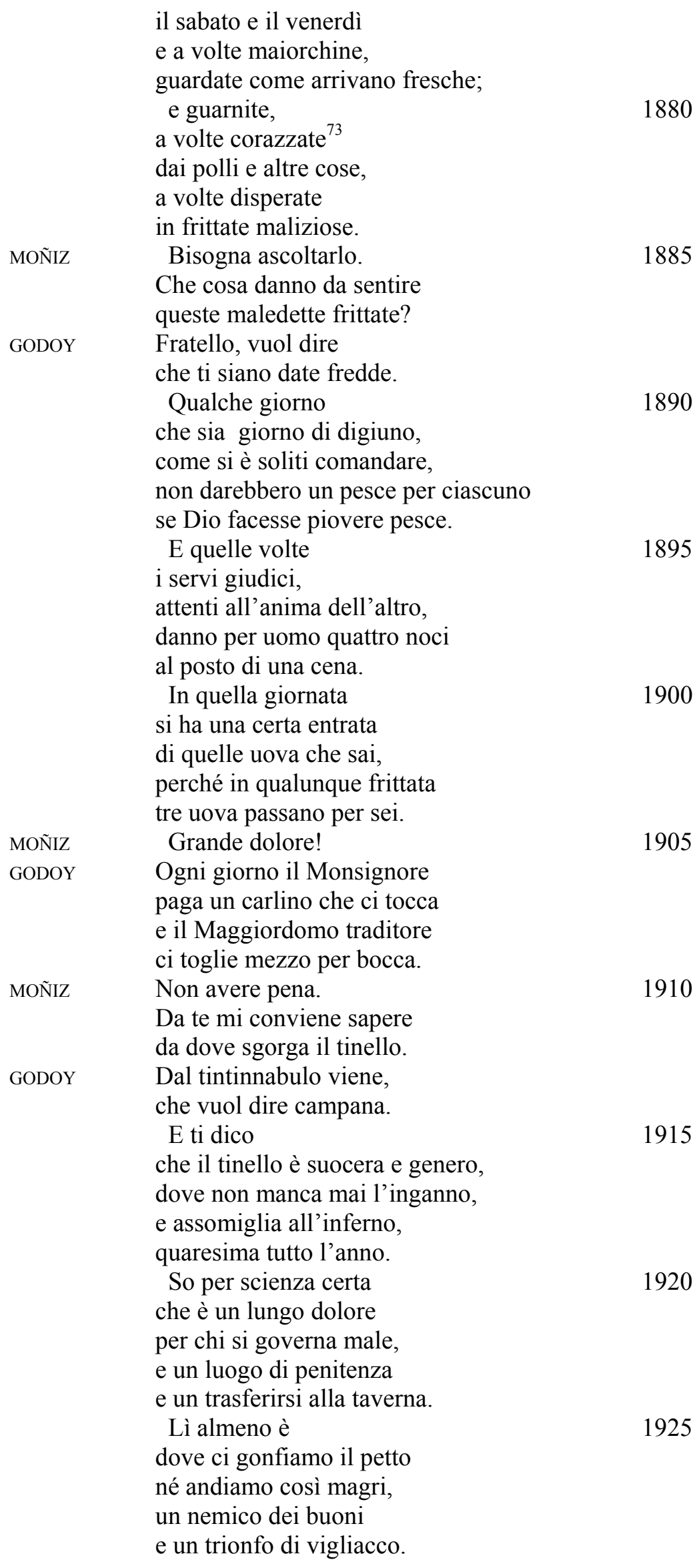

\footnotetext{
${ }^{73}$ Encoraçados, encorazado: « Cubierto y vestido de coraza. Tiene poco uso»; 2.«Vale también hecho a manera de corza, y cubierto de cuero».
} 
MOÑIZ

MOÑIZ

GODOY

MOÑIZ

GODOY

MACCHIATO

GODOY

MACCHIATO

GODOY

CCHIATO

GODOY

GODOY
Va bene.

È un'usanza vile

che al signore non porta guadagno,

che a nessun buono si da

se no fra due una stanza.

Fu fatta quando

1935

da quel che io so

erano tempi ragionevoli,

e la buona usanza era

che noi eravamo amabili.

Ma oggi giorno

1940

regna tanta fantasia

tra gli uomini, da quel che vedo,

che non c'è uomo che entrerebbe

nemmeno in tutto il Colisseo.

È vero.

1945

Giuro sulla mia fede che la tua bontà

mi riferisce molte cose.

Io voglio la tua amicizia

finché sarò a Roma.

$\mathrm{Ci}$ divertiremo

e staremo insieme,

tra di noi non ci sarà zizzagna

e avremo un buon servo

che l'ho portato dalla Spagna,

di fiducia,

1955

anche se non molto sveglio,

ma ci servirà bene.

Giunge fresco? Che peccato!

Sarà un bisogno. ${ }^{74}$

Eccolo, lì.

1960

Avvicinati, vieni qui.

Che fresco e che presto!

Copriti, non stare così.

Da dove giungi, fratello?

Dalla Castiglia.

1965

Non sarebbe meraviglia.

$\mathrm{Ma}$, di che terra è tua madre?

Quattro leghe da Siviglia,

di lì era anche mio padre.

Desidero

che tu mi dica quale indizio

ti ha portato a Roma.

Vengo per un beneficio

che mi dia da vestire e da mangiare.

Bene.

1975

Ma chi te lo darà?

Si richiedono lavori.

Dicono che il Papa li da

a tutti quelli che vogliono.

Con fortuna

avrai a campo dei Fiori

un paio di canonicati.

\footnotetext{
${ }^{74}$ I bisognosi, ver la comedia Soldatesca.
} 

MACCHIATO Per Dio signore, non vengo
a cercare né cani né gatti.
GODOY Con ragione.

Se il Papa Leone

lo vuole può togliervi dal male

e con un bastone santo

farvi diventare cardinale.

MACCHIATO Con molto piacere.

1990

MOÑIZ E lo sapresti fare?

MACCHIATO Certo che lo strasaprei.

GODOY In che modo?

MACCHIATO

Mangiando

più di dieci volte al giorno.

MOÑIZ Per la tua vita,

quale sarebbe il tuo pasto?

MACCHIATO Molta carne con mostarda

e ad ogni pasqua frollita

una gallinona grassa.

MOÑIZ Che ti sembra?

Che è un uomo che lo merita

e era in lui ben impiegato

e qualunque bene gli si offre.

Ma è un po' sfortunato.

MACCHIATO Da che lo deduci?

GODOY

Come, tu che hai grandi orecchie

non lo sai?

MACCHIATO In che cosa ancora?

GODOY

Che hai

la sfortuna in quelle sopracciglia.

MACCHIATO Si può provare

2010

a toglierle

senza che corra dei rischi?

GODOY Se vuoi pagare,

prima che passi un credo.

MOÑIZ

Fai tu

2015

che per servizio di Dio

è giusto che si faccia.

GODOY Che ci serva tutti e due,

che in fondo non voglio un'altra paga.

MACCHIATO Mi fa piacere.

GODOY

Guarda qui come si fa,

ma non devi mostrarlo.

MACCHIATO Che cosa mi fa e mi disfa?

Io saprò, signore, tacerlo.

GODOY Stai fermo.

2025

MACCHIATO Fermissimo, ${ }^{75}$

GODOY

Non avere paura

MACCHIATO Ay, ay, ay!

GODOY

O Dio che fastidio!

MACCHIATO Per Dio ci è mancato un dito

per strapparti l'occhio.

GODOY

Dunque, fratello,

quando esci, a questa mano,

dove vedrai certo calcestruzzo,

\footnotetext{
${ }^{75}$ Passito: «Usado como adverbio, vale quedito, con gran tiento», en DA. Quedo= quieto
} 
entra e uscirai sano,

che è la santa cantina.

MACCHIATO Dio lo voglia

con chi arriva in questa terra

e anche con chi vi sta!

Che diavolo, qui alla 'bodega'

la chiamano cantina!

Gente strana!

2040

e alla 'perra' dicono cagna,

e a molti uomini di grade affare,

e agli 'açumbres" ${ }^{76}$ della Spagna

gli chiamano qui boccali.

\begin{tabular}{ll} 
GODOY & Ha notato bene \\
MACCHIATO & E so ancora. \\
GODOY & \multicolumn{1}{c}{ Dimmi, } \\
& ma chi diavolo ti ha insegnato? \\
MACCHIATO & So messer sì, messer no
\end{tabular}

e il canchero che ti venga.

TROMBETTA Cavalieri,

2050

siamo cinque trombettisti,

diteci ora e vediamo

chi ci darà questi danari della mancia

che aspettiamo.

MOÑIZ

È chiaro

2055

che la darà il Maggiordomo.

Il nostro signore dà i denari a lui.

TROMBETTA Da Natale fino ad oggi

ci rimanda di giorno in giorno.

MOÑIZ Davvero?

2060

Allora voglia Dio

che il prossimo Natale abbia pagato,

e speriamo che vi dia la metà

di quel che avrebbe dovuto.

TROMBETTA È di quelli?

2065

Ci lamenteremo dopo

e si devono far conoscere i suoi modi.

MOÑIZ Ci sono più di tre

che si lamentano e il Cardinale più di tutti.

TROMBETTA Può essere?

GODOY

Io penso

che dobbiamo andare via,

i servi vogliono sicuramente

mangiare ora.

\footnotetext{
${ }^{76}$ Açumbres, azumbres: «Cierta medida de las cosas líquidas, como agua, vino, vinagre, o leche, que es la octava parte de una arroba: y promiscuamente se llama azumbre la medida, y lo que se contiene en ella: y así se dice comunemente que Fulano se bebió una azumbre de vino, esto es la cantidad de vino que se contiene en la medida dicha azumbre. Es voz árabe, que viene de zumbri, que significa esto mismo, y añadida la partícula A se dijo azumbre», en DA.
} 


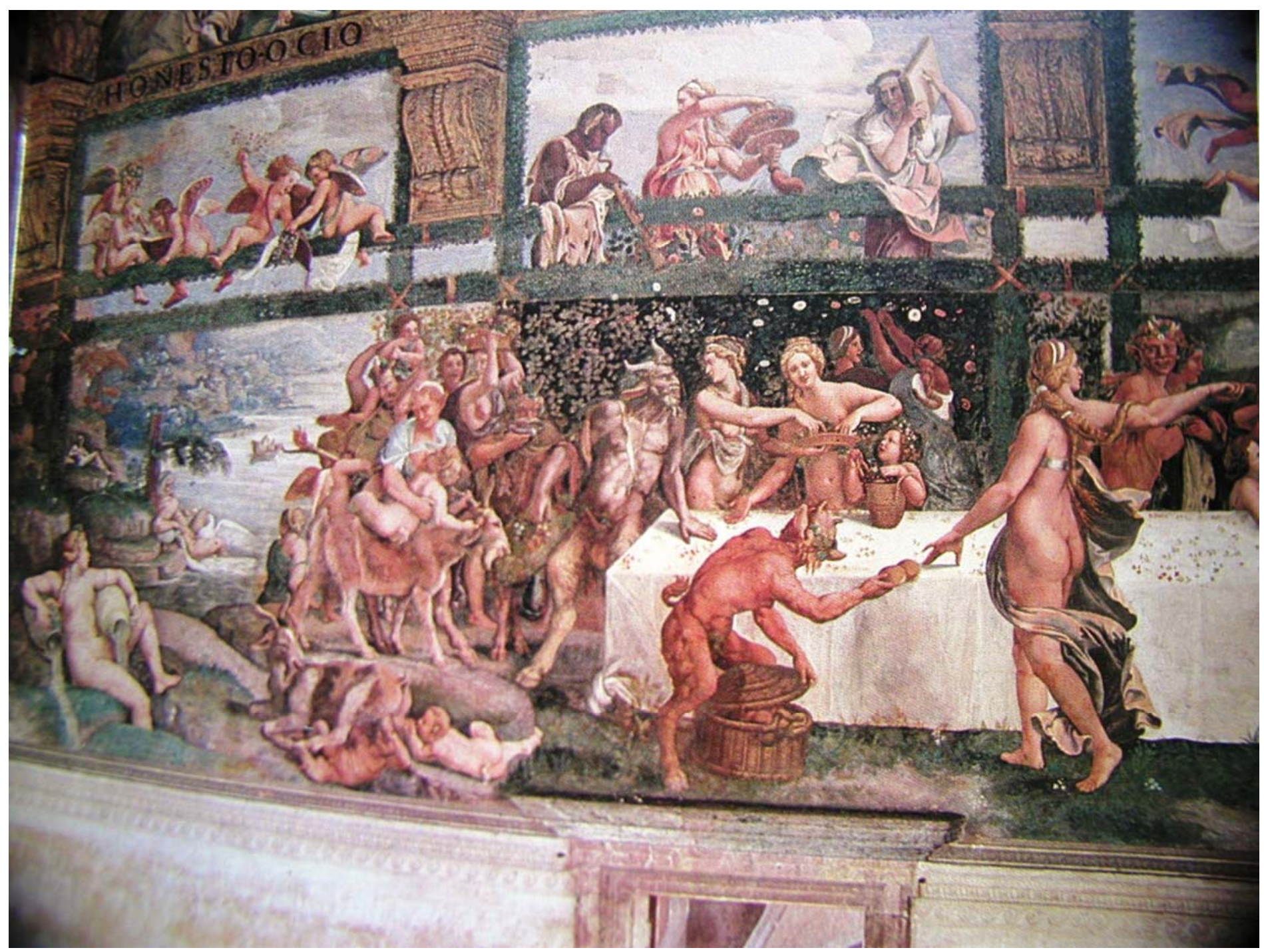

Giulio Romano, particular del banquete nupcial, sala de Psique, Palacio Te, Mantova (1527-1529) 
SCALCO Ora Dio sia lodato!

Se la mia inclinazione non mi inganna,

io sono l'uomo più sfortunato

che sia mai giunto dalla Spagna.

Non so che cosa mi succede

Tutta la vita servendo

2080

e povero così,

sembra che da me

fuggano i benefici.

Grandi fatiche!

E non conferiranno

almeno a me una ermita

Ma come me la danno,

poi l'altro risuscita.

Posso dire

che chi vuole vivere

mi dia la sua vacante

che, anche se sta per morire,

io vado che lui si alzi.

MATTIA Tu sbagli.

Non chiedi mai nulla,

ti perdi in fragilità.

Attenzione, se non importuni,

morirai in ospedale.

SCALCO Oh Mattia!

Oggi si trovano pochi uomini

con una sfortuna così grande come la mia

e tanto chiedono notte e giorno

quelli che servono bene e sanno star zitti!

MATTIA Sarà così;

ma, per quel che accade

fa centro chi si relaziona bene,

a me sembra una zucca

la testa che non parla.

SCALCO Senza dubbio.

Tacere continuamente

sarebbe una follia bestiale,

ma devi notare

quello che succede a me.

Cerca di capire,

semplice animale,

faccio un esempio simile:

se dessero al Cardinale

la vacante della tua terra;

e lui la attribuisse

al primo arrivato,

non penseresti che sbaglia?

Sarebbe bene che sapesse

chi siamo quelli di quella terra.

Se questo conta,

farà che Dio non lo dimentichi

aiutando chi patisce,

perché a volte chi chiede 


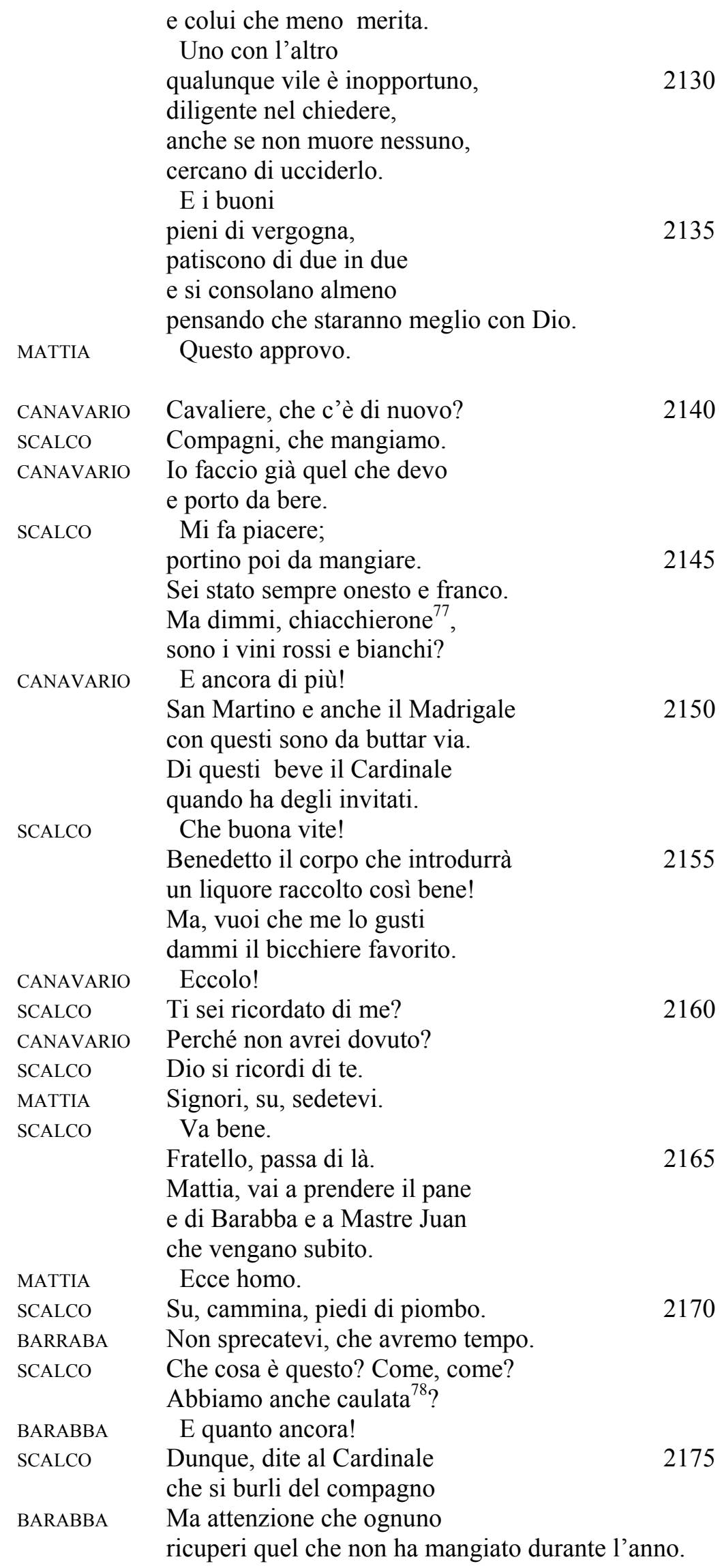

\footnotetext{
${ }^{77}$ Bachiller: «Comunmente, y por vilipendio se da este nombre, y se entiende por el que se habla mucho fuera de propósito, y sin fundamento», en DA.

${ }^{78}$ Caulada. En it. caulo=cavolo, en Zanicchelli.
} 


\begin{tabular}{|c|c|c|}
\hline \multirow[t]{6}{*}{ SCALCO } & $\mathrm{Su}$, gentiluomini! & \multirow[b]{2}{*}{2180} \\
\hline & $\begin{array}{l}\text { Vai di là, Metreianes, } \\
\text { e tu Barabba, sei secondo; } \\
\text { facciamo diminuire le fatiche } \\
\text { che passiamo per il mondo. }\end{array}$ & \\
\hline & $\begin{array}{l}\text { Tu, Mattia, versa ancora del vino, } \\
\text { non smettere mai e stai allerta. }\end{array}$ & 2185 \\
\hline & Io vorrei soprattutto & \\
\hline & $\begin{array}{l}\text { che tu non aprissi la porta a nessuno. } \\
\text { Vedi chi è? }\end{array}$ & \\
\hline & Tieni i piedi ben a terra. & 2190 \\
\hline BARABBA & Deve essere qualche villano. & \\
\hline CANAVARIO & Quante gente scortese c'è! & \\
\hline MATTIA & Signore, l'Arcidiacono. & \\
\hline \multirow{2}{*}{ SCALCO } & Lascia stare. & \\
\hline & $\begin{array}{l}\text { Che si stanchi di chiamare, } \\
\text { dato che è venuto così tardi. }\end{array}$ & 2195 \\
\hline BARABBA & Oggi lo farete digiunare. & \\
\hline CANAVARIO & Apritegli che non ha mangiato & \\
\hline \multirow{2}{*}{ SCALCO } & Come no? & \\
\hline & Sua madre puttana! & 2200 \\
\hline BARABBA & Di più mio padre con la gamba che si ritrova. ${ }^{79}$ & \\
\hline SCALCO & $\begin{array}{l}\text { Ha più rendita di me, } \\
\text { e vicino ha la taverna. }\end{array}$ & \\
\hline \multirow[t]{2}{*}{ BARABBA } & Che consolazione! & \\
\hline & $\begin{array}{l}\text { La presunzione in cielo, } \\
\text { la prudenza sotto i piedi. }\end{array}$ & 2205 \\
\hline SCALCO & $\begin{array}{l}\text { Se un giorno perde il tinello, } \\
\text { avrà da piangere per un mese. }\end{array}$ & \\
\hline \multirow[t]{3}{*}{ BARABBA } & $\begin{array}{l}\text { Non bisogna aprire, } \\
\text { perché ho sentito dire è un uomo }\end{array}$ & 2210 \\
\hline & $\begin{array}{l}\text { così miserabile e vile } \\
\text { che si lascerà morire }\end{array}$ & \\
\hline & pur di non spendere un quattrino. & \\
\hline \multirow[t]{2}{*}{ SCALCO } & Grande Uomo! & \\
\hline & $\begin{array}{l}\text { Non perde congregazione, } \\
\text { cavalca sempre con grazia. }\end{array}$ & 2215 \\
\hline BARABBA & $\begin{array}{l}\text { Non tanto per servire il padrone, } \\
\text { quanto per scampare alla contumacia. }\end{array}$ & \\
\hline \multirow{3}{*}{ SCALCO } & Sapete chi & \\
\hline & mi sembra un uomo per bene? & 2220 \\
\hline & Il suo compagno, l'Abate. & \\
\hline BARABBA & $\begin{array}{l}\text { Se mi date un carlino } \\
\text { io dirò qui la verità. }\end{array}$ & \\
\hline SCALCO & Dilla fratello. & \\
\hline \multirow[t]{2}{*}{ BARABBA } & Il cardinale Suriano & 2225 \\
\hline & l'ha licenziato per la sua testardaggine. & \\
\hline SCALCO & $\begin{array}{l}\text { Come mai il Monsignore Egiziano } \\
\text { stando così le cose lo ha assunto? }\end{array}$ & \\
\hline \multirow[t]{2}{*}{ BARABBA } & Non so nulla. & \\
\hline & Con una sottana prestata & 2230 \\
\hline
\end{tabular}

\footnotetext{
${ }^{79}$ Mas mi padre por la pierna: «The preceding: ;La puta que lo parió! Is equivalent to the common exclamation ¡Mi madre! iSu madre!, and the answer to this is a reference to padre (...) the two forming the pair necessary for erotic suggestion (...). The addition of por la piena is merely a reinforcement, quite gratuitous and naturally also of an erotic nature» (Gillet, 1951, III, 525, v.127).
} 
ingannerebbe anche il diavolo.

CANAVARIO Giuro su Dio che era noleggiata

io l'ho vista nel ghetto.

SCALCO Non lo dubito.

BARABBA Il saione ${ }^{80}$ di velluto

non ha aperto forse la strada al mantello?

CANAVARIO È di un giovane barbuto,

palafreniere del Papa.

SCALCO Dunque io esco,

questi fatti imbarazzanti

lo possono danneggiare.

BARABBA Non vedi che la sua nobiltà

si va frantumando?

SCALCO Certo, oggi giorno

ci sono uomini di fantasia

che pensano di essere goti,

e che la nobiltà consiste

nel sedersi sulla testa di tutti.

METREIANES Ge sé bien

que monsiur no mange rien. ${ }^{81}$

2240

SCALCO Io avevo poca fame,
ma datemi del vino.

BARABbA Dagli presto, Mattia.

SCALCO Questo, fratello,

e passa avanti.

BARABBA Io muoio dalla sete.

SCALCO Io, che sono nato prima,

rompo la lancia per primo.

CANAVARIO Va bene.

Venga dopo da questa parte,

2260

moriamo valorosamente.

SCALCO

Trich $^{82}$

CANAVARIO

$$
\text { Esguaz. }{ }^{83}
$$

BARABBA

Smettila,

che voglio la mia sputacchiera. ${ }^{84}$

METREIANES Notra Dama

vus ete! $!^{85}$

SCALCO Va a vedere chi sta chiamando; guarda dallo spiraglio della porta.

CANAVARIO Deve essere Mossén Retama, ${ }^{86}$ queste sono le sue ore certe.

SCALCO Può essere,

ci fa perdere del tempo per mangiare.

Dì che sua madre non è qui. ${ }^{87}$

BARABBA

A me tocca bere

per l'anima di suo padre.

\footnotetext{
${ }^{80}$ Sayón: hace también referencia a judío: «giudeo, socio di una confraternita che, nelle processioni di settimana santa, veste un saione e rappresenta appunto un ebreo», en diccionario Carbonell.

${ }^{81}$ Io so bene che il signore non mangia nulla.

82 Trinca.

${ }^{83}$ Bevi.

${ }^{84}$ «Bicchiere e sputacchiera per fare risciacqui», en Carbonell; «Enjuague para los dientes», en DLE, RA

${ }^{85}$ Nostra signora, vi aiuti

${ }^{86}$ «Possibly a Catalan dignitary, still entirely unknown to us» (Gillet, 1951, III, 531, v. 193).

87 Di que no está acá su madre: alusión «with vaguely erotic and insulting intent» (ibid, v. 197).
} 
Sapete chi è?

È quel uomo per bene

che ha la berretta rossa.

SCALCO Che mi diano un mal vescovato

se voi non ci avete azzeccato.

BARABBA

Che non entri qui.

MATTIA Sta chiamando?

SCALCO

Si stancherà

2280

Che scudieroni negri!

CANAVARIO Se ne andrà in taverna

a impegnare i suoi cammellotti.

SCALCO Hai visto, fratello,

che cervello di anziano vecchio

per avere un governo?

Cammellotti d'estate,

cammellotti d'inverno.

BARABBA Si, signore,

perché loro

hanno protetto lui d'estate,

e ora lui, riconoscente,

protegge loro dal freddo.

Questo uomo crudele

muore dietro a una Isabella,

per la quale arde ed è cieco,

e il cammellotto per lui,

è stare vicino al fuoco.

SCALCO

Pusillanimi

carichi di benefici!,

che vi venisse la peste

se gli mancano dieci ducati

per farsi una veste.

CANAVARIO Io vi assicuro

che la povertà è un grande difetto

2305

se l'uomo è franco.

SCALCO Il poveretto non ha più

di mille ducati in banca.

BARABBA Mille frustate,

e su i cammellotti,

attraverso Roma a mezzogiorno.

SCALCO Per Dio, fratello, guarda come si tramuta Mattia.

BARABBA Sì, sì, sì.

METREIANES Balle vn petí, mon ami. ${ }^{88}$

CAVARIO

Bevo ancora.

BARABBA

Io faccio il resto.

SCALCO Ma ricordati di me.

CANAVARIO Dacci a tutti e presto.

BARABBA Non fermiamoci,

che a seconda di come ci comportiamo

abbiamo la ubriacatura certa.

SCALCO Per Dio, siamo in pericolo

se non centriamo la porta.

BARABBA Traditore!

Che vita saporita

${ }^{88}$ Dammi un poco amico mio. 
avrei di sicuro

se il Monsignore fosse papa

e io il cardinale favorito!

SCALCO Che dici?

Io, il poveretto Agostino Chigi. ${ }^{89}$

MATTIA Alla fede, io Datario.

MAtreianes Moi, Gran Metre de París. ${ }^{90}$

CANAVARIO E io, muoio Canavario.

SCALCO Hai chiesto bene

$\mathrm{e}$, perciò che hai detto,

2335

bevi, su, che non c'è di quella cosa.

CANAVARIO Tu, Signore, mi hai redento

attraverso il tuo prezioso sangue;

non sono degno

di bere acqua senza vino

per l'amore ardente

ma per il tuo verbo divino

berrò vino senza acqua.

BARABBA Latinaris?

Calicem, dunque, salutaris,

io spero vedervi alla fine

e perciò estis singularis

nomen Domini invocabo. ${ }^{91}$

SCALCO Figli di buona madre,

cominciate con i latini?

tenete gli occhi aperti.

CANAVARIO Cercate qui due quattrini

e mandate due a prendere le castagne.

SCALCO Buon conto!

Entreranno qui in cinquanta

e ci rovineranno tutto.

BARABBA Sarebbe un grande affronto

se spendesse tutto nel bere.

SCALCO Su, Mattia,

porta via queste cose.

Lascia il vino e porta via il pane.

CANAVARIO Volete, per gentilezza,

che beviamo ugualmente? ${ }^{92}$

SCALCO Prendete in mano,

senza berrette, fratelli!

CANAVARIO Avanti da una mano all'altra.

SCALCO Tiriamo su le braccia sane

CANAVARIO Viva!

\footnotetext{
${ }^{89}$ «Agostino Chigi, uno de los banqueros más ricos de Italia. En la línea siguiente el Datario se refiere al encargado de la Dataria apostólica, Silvio Passerini, quien repartía los beneficios de la Cancillería. Passerini sempre alcanzaba beneficios para sí»), en Mc Pheeters (1979, 176, nota 41).

${ }^{90}$ Io, Gran Maestro di Parigi

${ }^{91}$ Parli latino?

Calice, dunque, salute, io spero vedere il fondo; e siccome siete unico invocherò il nome del Signore.

92 Aután: «Trae esta voz Covarr. en su Tesoro, y dice que es francesa introducida en el castellano, y que vale lo mismo que al tanto, igualmente, y que tiene uso entre la gente ordinaria, para significar que han bebido igualmente igual cantidad en los brindis que se han hecho reciprocamente. En lo moderno apenas tiene uso», en DA.
} 


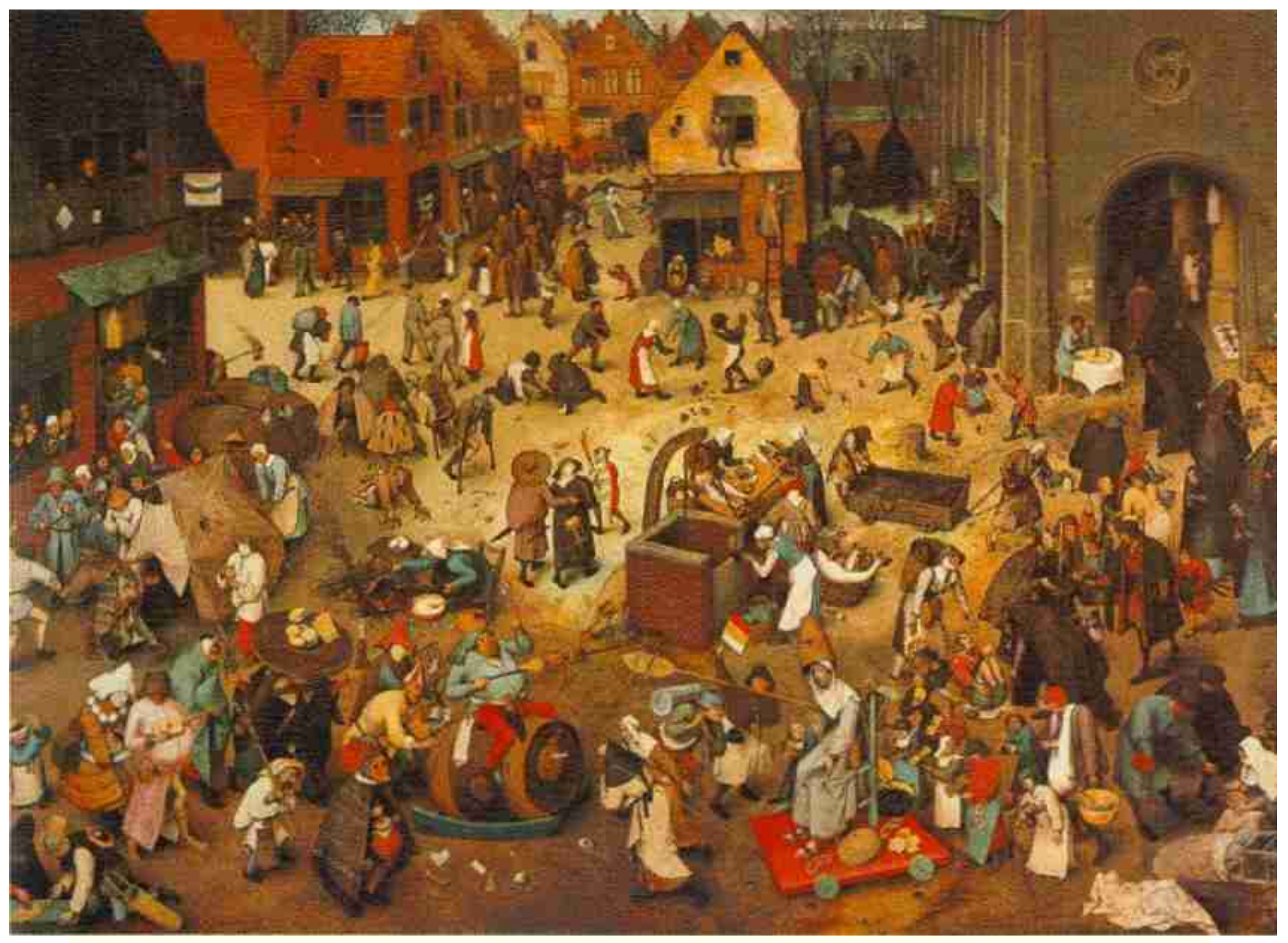

Pieter Bruegel, La lucha entre el Carnaval y la Cuaresma, 1559, Kunsthistorisches Museum, Viena 
Scalco, che io mi bevo voi.

$\begin{array}{ll}\text { SCALCO } & \begin{array}{l}\text { Aspettate, ora corriamo. } \\ \text { CANAVARIO }\end{array} \\ \text { Sono apposto quei due! } \\ \text { Date qua, vediamo. } \\ \text { METREIANES } & \begin{array}{l}\text { Mon ami, } \\ \text { ge bib a vus. }{ }^{93}\end{array}\end{array}$

Che competitore forte!

SCALCO Giuro su Dio che finora

tutti ci abbiamo guadagnato onore.

CANAVARIO Che vi sembra?

MATTIA $\mathrm{Su}$, signori, che fa notte.

2380

SCALCO Corri, accendi una candela

MATTIA Il Cardinale lo merita,

ma non c'è chi di lui si duole.

CANAVARIO Oh, Mattia!

Ma...tu...tía, se è giorno, ${ }^{94}$

e quando...

MATTIA

Cantate battendo le mani?

CANAVARIO Su, cantiamo, compagnia.

MATTIA pater noster, per le loro anime.

CANAVARIO Ti bel pé. ${ }^{95}$

MATTIA Sono ben messi, davvero.

CANAVARIO Coraro!

MATTIA

CANAVARIO

MATTIA

Non cantano male.

Questa è musica papale.

CANAVARIO Et infra...

MATTIA Passerà avanti.

CANAVARIO Et infra labriel el mazo. ${ }^{96}$

MATTIA Signori, è già tardi,

fatte come se ci fosse già stata la bacchettata.

Barabba,

due parola ancora e basta:

2390

combattiamo, se ti piace.

BARABBA Per tutto mi troverai.

Ma tienimi se cadessi.

MATTIA Alza il dito.

BARABBA Non ti muovere.

MATTIA

BARABBA

MATTIA

SCALCO

MATTIA

Non avere paura.

Per Dio, presto gliele darei

$\mathrm{Su}$, Scalco!

Stai fermo.

Magari cadesse,

fermo tu,

che sei ordinario.

\footnotetext{
${ }^{93}$ Amico mio, bevo per te.

${ }^{94}$ Ma... tu... tía, si es de día: «unguento medicinal hecho con atutía. Cejador, Vocabulario, 399, declares that atutía, or tutia was used for colirios, that is eye medicines, and this may give a clue to aur line. In this scene it is getting dark and Escalco has just called for candle. May we suppose that the Canavario, drunk and half asleep, with his eyes closing, starter to say Mathía, si es el dia and half consciously associeted the sound of the proper name and his own inability to see with the eye-edicine (a) tutia?» (Gillet, 1951, III, 534, v. 311)

95 «Estas palabras del Canavario no tienen sentido. No parecen ser italianas; si la línea se atribuye a Metreianes, podría ser una expresión en francés algo como "tite belle p...."» en Mc Pheeters, 1979, 178, nota 45.

${ }_{96}$ «Tal vez frases de la misa de maitines», ibid.
} 
Mon ami?

\author{
Alon. ${ }^{97}$ \\ Ordinario!
}

Uno è già per terra.

Oh, pusillanimi!

Che belli e affiancati!

Come mantengono la stofa!

Chi di voi dei più stirati

mi spegnerà la candela?

BARABBA

Barabba.

Ma, a quanto me la dai,

per Dio, fratello, Mattia?

MATTIA Non a più di quattro soffi.

Hai un boccale di malvasia.

BARABBA Arrivo.

MATTIA Tieni il vino!

BARABBA

Dunque conta.

MATTIA

Questa è lei, se non mento.

Orza!, orza!

BARABBA

Sono già due.

MATTIA

BARABBA

MATTIA

viaggio e salvazione!

Quante sono?

BARABBA

Le tre, ti rimangono ancora?

MATTIA

Dio lo voglia, San Antonio,

e sotto terra vado con questo.

Cavalieri,

aiutate i compagni,

date la mano con forza!

SCALCO Dove sono?

MATTIA

Lì di fronte.

Dio vi valga, ingiuriate!

Sancta Maria

ora pro eos!

SCALCO

Mattia,

aiutami ad alzarmi.

MATTIA Dammi la mano, su, via,

cominciamo a danzare

Fermati tu!

Così due a due,

o tutti quattro in fila

e viva la fede in Dio,

oh, valorosi servi!

Per di qui,

per di qua, corpo mio!

Non la carichiamo quest'anno.

Cardinale, povero te,

poco onore e molto danno.

Vedete, signori?

Come questi ci sono mille traditori,

${ }^{97}$ Andiamo 
se volete mettere le menti,

che sprecano i vostri onori,

e voi, innocenti.

Onore e vita

vi mandi Dio compiuta,

con una rendita soddisfacente.

La Tinellaria è offerta:

vi valga e buon pro vi faccia. 